\title{
Werkgelegenheid en scholing 2003
}

Citation for published version (APA):

Researchcentrum voor Onderwijs en Arbeidsmarkt, ROA. (2004). Werkgelegenheid en scholing 2003. Researchcentrum voor Onderwijs en Arbeidsmarkt, Faculteit der Economische Wetenschappen. ROA Reports No. 1 https://doi.org/10.26481/umarep.2004001

Document status and date:

Published: 01/01/2004

DOI:

10.26481/umarep.2004001

Document Version:

Publisher's PDF, also known as Version of record

\section{Please check the document version of this publication:}

- A submitted manuscript is the version of the article upon submission and before peer-review. There can be important differences between the submitted version and the official published version of record.

People interested in the research are advised to contact the author for the final version of the publication, or visit the DOI to the publisher's website.

- The final author version and the galley proof are versions of the publication after peer review.

- The final published version features the final layout of the paper including the volume, issue and page numbers.

Link to publication

\footnotetext{
General rights rights.

- You may freely distribute the URL identifying the publication in the public portal. please follow below link for the End User Agreement:

www.umlib.nl/taverne-license

Take down policy

If you believe that this document breaches copyright please contact us at:

repository@maastrichtuniversity.nl

providing details and we will investigate your claim.
}

Copyright and moral rights for the publications made accessible in the public portal are retained by the authors and/or other copyright owners and it is a condition of accessing publications that users recognise and abide by the legal requirements associated with these

- Users may download and print one copy of any publication from the public portal for the purpose of private study or research.

- You may not further distribute the material or use it for any profit-making activity or commercial gain

If the publication is distributed under the terms of Article $25 \mathrm{fa}$ of the Dutch Copyright Act, indicated by the "Taverne" license above, 


\section{Werkgelegenheid en scholing 2003}

ROA-R-2004/1

\section{Researchcentrum voor Onderwijs en Arbeidsmarkt}

Faculteit der Economische Wetenschappen en Bedrijfskunde Universiteit Maastricht

Maastricht, juni 2004 
ISBN 90-5321-388-0

Sec04.013.doc 


\section{Inhoud}

Bladzijde

Voorwoord

Resumé $\quad$ iii

1 Inleiding 1

2 Risicofactoren en verschuivingen in gevraagde competenties 9

2.1 Inleiding 9

$\begin{array}{ll}2.2 \text { Belastende arbeidsomstandigheden } & 10\end{array}$

$\begin{array}{ll}2.3 \text { Technologische en organisatorische ontwikkelingen } & 22\end{array}$

2.4 Ontwikkelingen in de structuur van de werkgelegenheid 26

2.5 Verschuivingen in de gevraagde competenties 30

$\begin{array}{ll}2.6 & \text { Samenvatting } \\ & 38\end{array}$

3 Scholing 45

3.1 Inleiding 45

$\begin{array}{lll}3.2 & \text { Scholingsinspanningen } & 45\end{array}$

3.3 Risicogroepen op de Nederlandse arbeidsmarkt 54

3.4 De rol van opleidingsfondsen $\quad 56$

3.5 Het gebruik van middelen uit het Europese Sociale Fonds (ESF 3) 65

3.6 Scholing, risicofactoren en ESF: 13 sectorprofielen 71

4 De effectiviteit van scholingsinspanningen $\quad 79$

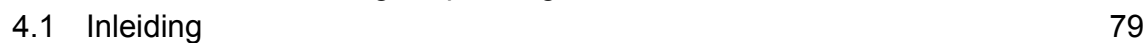

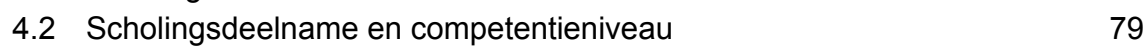

4.3 Scholing en de kans op behoud van werk 82

$\begin{array}{lll}4.4 & \text { Effectieve scholing } & 87\end{array}$

$\begin{array}{lll}4.5 & \text { Conclusies } & 88\end{array}$

5 Groepen met een achterstand $\quad 91$

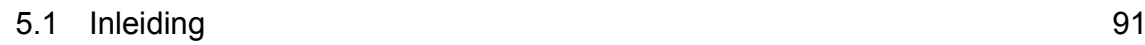

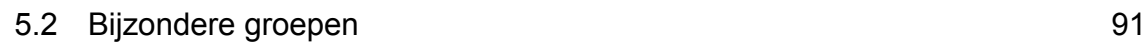

5.3 Fysieke belasting 96

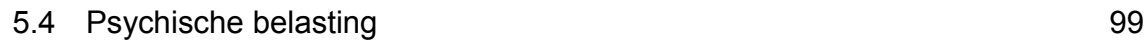

$\begin{array}{ll}5.5 \text { Beeldschermwerk } & 103\end{array}$

$\begin{array}{ll}5.6 & \text { Scholingsparticipatie } \\ 5.7 & \text { Conclusies }\end{array}$

$\begin{array}{lll}5.7 \text { Conclusies } & 111\end{array}$

6 Risicoprofielen en doelgroepen voor het scholingsbeleid 115

$\begin{array}{ll}6.1 \text { Inleiding } & 115\end{array}$

$\begin{array}{ll}6.2 \text { Risicoprofielen } & 115\end{array}$

$\begin{array}{ll}6.3 \text { Doelgroepen voor scholingsbeleid } & 120\end{array}$

$\begin{array}{ll}6.4 \text { Kansrijke scholingstrajecten } & 122\end{array}$ 



\section{Voorwoord}

Werkgelegenheid en scholing 2003 en de bijbehorende Statistische Bijlage is na Werkgelegenheid en scholing 1996, 1997, 1999 en 2001 de vijfde versie van een overzichtsrapport in het kader van het Werkgelegenheid en Scholing Observatorium (WSO) dat het Researchcentrum voor Onderwijs en Arbeidsmarkt (ROA) in opdracht van het Ministerie van Sociale Zaken en Werkgelegenheid heeft opgesteld.

Doel van dit observatorium is het in beeld brengen van (1) de ontwikkelingen die ervoor zorgen dat kwalificaties van werkenden verouderen en dat als gevolg daarvan het risico bestaat dat werkenden hun werk geheel of gedeeltelijk verliezen en (2) de ontwikkelingen op het gebied van scholing, die verlies van werk vanwege competentieveroudering kan tegengaan. Het tweejaarlijkse beeld van deze ontwikkelingen dat door het observatorium wordt gegeven maakt het mogelijk om tijdig inzicht te krijgen in de scholingsactiviteiten binnen branches en bedrijven en de lacunes die er op dit punt optreden.

Ten opzichte van de vorige rapportages van het WSO is de opzet van dit rapport wat gewijzigd. Om meer aandacht te kunnen schenken aan enkele speciale onderwerpen, worden de factoren die een rol spelen bij competentieveroudering in één hoofdstuk (hoofdstuk 2) apart toegelicht. Dit hoofdstuk geeft een integraal overzicht van de mate waarin en waardoor bepaalde groepen werkenden een verhoogd risico lopen op competentieveroudering. In hoofdstuk 3, waarin de deelname aan scholing centraal staat, wordt naast de gebruikelijke cijfers met betrekking tot de scholingsparticipatie, uitgebreid stilgestaan bij de rol die opleidings- en ontwikkelingsfondsen (O\&O fondsen) spelen bij het realiseren en faciliteren van opleidingsinspanningen. Daarnaast zal er aandacht worden besteed aan het gebruik van ESF-middelen voor de financiering van opleidingsinspanningen.

Een tweede nieuw element in deze rapportage is de aandacht voor de effectiviteit van de scholingsinspanningen. In hoofdstuk 4 wordt de effectiviteit van scholingsinspanningen vanuit twee perspectieven empirisch onderzocht. Allereerst wordt er gekeken naar de relatie tussen de scholingsdeelname en het competentieniveau van werkenden. Daarbij staat de vraag centraal of scholingsinspanningen ook daadwerkelijk iets opleveren in termen van het verbeteren van iemands competenties. Daarnaast wordt er gekeken naar de effectiviteit van scholing bij het verminderen van het risico op verlies van werk vanwege competentieveroudering. De effectiviteit van de scholingsinspanningen in de verschillende bedrijfssectoren komt ook terug in de sectorale risicoprofielen die in het laatste hoofdstuk gepresenteerd worden.

Een laatste verandering ten opzichte van vorige rapportages van het WSO betreft de aandacht die er wordt besteed aan groepen met een mogelijke achterstandspositie. In een apart hoofdstuk worden de risicofactoren en de scholingsdeelname van vrouwen, etnische minderheden, jongeren en oudere werknemers in kaart gebracht.

Net zoals dat in de vorige rapportage het geval was, staat in dit overzichtsrapport de informatie naar bedrijfssector centraal. Hierbij wordt er echter ook gekeken naar de 
bestaande risico's en de scholingsinspanningen van de werkenden in de verschillende beroepssectoren en opleidingssectoren binnen de verschillende bedrijfssectoren. Deze aanpak heeft twee belangrijke voordelen. Allereerst is het op deze manier veel beter mogelijk om specifieke doelgroepen voor het scholingsbeleid te traceren. Daarnaast biedt deze aanpak mogelijkheden om inzicht te krijgen in het belang van sectoroverstijgende scholing.

In het laatste hoofdstuk worden de eerder gepresenteerde indicatoren aan elkaar gerelateerd. Dit maakt het mogelijk om doelgroepen voor het scholingsbeleid te identificeren. Vervolgens wordt er aandacht besteed aan de scholingstrajecten die de positie van deze doelgroepen zouden kunnen verbeteren. Daarbij zal er gekeken worden naar zowel scholing die gericht is op het verbeteren van de positie van de desbetreffende groep werkenden binnen een bepaalde bedrijfssector, alsook naar scholing die als doel heeft om een overstap naar een andere bedrijfssector mogelijk te maken ('sectoroverstijgende scholing').

De bij dit rapport behorende Statistische Bijlage heeft als doel om per bedrijfssector een totaaloverzicht te geven van de in het rapport besproken indicatoren voor alle onderscheiden beroepssectoren (9) en opleidingssectoren (13). De Statistische Bijlage is daarom geordend naar bedrijfssector. Op deze wijze kan de Statistische Bijlage waarschijnlijk het meest adequaat fungeren als naslagwerk. Het laatste deel van de Statistische Bijlage bevat alle in dit rapport gebruikte indicatoren voor de totale werkzame bevolking. Dit geeft een overzicht van de gemiddelde risico's op competentieveroudering en de verwachte scholingsinspanningen voor de gehele werkzame bevolking. Doordat dit laatste deel minder beperkt wordt door restricties op het gebied van betrouwbaarheid en presenteerbaarheid, kunnen er voor zowel opleidingen als beroepen veel gedetailleerde cijfers worden gepresenteerd.

De projectleiding van het WSO is in handen van prof. dr. A. de Grip. Drs. J.B. van Loo en drs. J.M.A.F. Sanders speelden een centrale rol bij de uitvoering van het onderzoek en de totstandkoming van de rapportage. Daarnaast is aan het onderzoek meegewerkt door Dr. J.P. Allen, die bijdroeg aan de analyses van de scholingseffectiviteit in paragraaf 4.3 en door S. Dijksman, die een belangrijke rol speelde bij de dataverzameling. Onze dank gaat uit naar de leden van de begeleidingscommissie bij het Ministerie van Sociale Zaken en Werkgelegenheid: drs. L. van der Vliet, drs. L. Bastiaansen en drs. V. Monfils. 


\section{Resumé}

Het Lissabon akkoord van de Europese Raad heeft het belang van de scholing van werkenden hoog op de politieke agenda geplaatst. Niet alleen is het voor een dynamische kenniseconomie cruciaal dat het overgrote deel van de beroepsbevolking beschikt over een startkwalificatie voor de arbeidsmarkt en er voor zorgt dat haar competenties up-to-date blijven en verder worden ontwikkeld. Ook is een grotere aandacht voor "een leven lang leren" cruciaal voor het verhogen van de arbeidsparticipatie van met name 50+'ers. Hierbij gaat het primair om het voorkomen van arbeidsmarktuittrede als gevolg van een of andere vorm van competentieveroudering.

Wanneer sociale partners en de overheid over goede informatie beschikken, kan een op de juiste doelgroepen en risicofactoren gericht scholingsbeleid voorkomen dat grote aantallen werknemers tijdelijk of zelfs permanent verloren gaan voor de arbeidsmarkt en in de uitkeringssfeer belanden. Om in de voor een dergelijk scholingsbeleid benodigde informatie te voorzien, brengt het Researchcentrum voor Onderwijs en Arbeidsmarkt (ROA) in opdracht van het Ministerie van Sociale Zaken en Werkgelegenheid de risico's van verlies van werk als gevolg van competentieveroudering én de scholingsinspanningen om die risico's te beperken in kaart. Dit doet ROA binnen het raamwerk van het door het Ministerie opgezette Werkgelegenheids- en Scholingsobservatorium (WSO). De centrale vraagstelling van het WSO kan als volgt worden verwoord:

Welke rol kan de scholing van werkenden spelen om de risico's op verlies van werk vanwege de verschuivingen in de gevraagde competenties te verminderen?

Vooral in tijden waarin de economie wat minder draait, zoals de laatste jaren het geval is, is het belangrijk om een goed overzicht te hebben van de risico's op verlies van werk die verschillende groepen werkenden lopen. Daarvoor is in de eerste plaats inzicht vereist in de factoren die het risico van verlies van werk vanwege competentieveroudering veroorzaken:

- belastende arbeidsomstandigheden;

- technologische en organisatorische vernieuwingen;

- verschuivingen in de werkgelegenheidsstructuur.

Op basis van de meest recente informatie wordt in hoofdstuk 2 in kaart gebracht in hoeverre de werkenden in de verschillende bedrijfssectoren met deze risico's worden geconfronteerd. Daarbij wordt er aangegeven welke beroepsgroepen in een bepaalde bedrijfssector het meest geconfronteerd worden met de desbetreffende risicofactoren. Op dezelfde wijze worden de risico-opleidingen in kaart gebracht. Op deze manier ontstaat er een beeld van de groepen werkenden waarvoor de risico's op verlies van werk vanwege competentieveroudering het grootst zijn.

Meer dan in de eerdere WSO rapporten gaat echter in dit rapport de aandacht uit naar het belang van de scholing van werkenden. Centraal staat daarbij de vraag: 
Hoe dragen scholingsactiviteiten van werknemers bij aan het behoud van werk?

Eerst wordt in hoofdstuk 3 de scholingsdeelname van werkenden nauwgezet in kaart gebracht en een overzicht gegeven van de groepen werkenden in de verschillende bedrijfssectoren waarvoor geldt dat de deelname aan scholingstrajecten dusdanig beperkt is dat zij zich mogelijk niet voldoende hebben gewapend tegen de risico's van competentieveroudering men loopt. Ook wordt ingegaan op de rol van Opleidings- en Ontwikkelingsfondsen (O\&O) en de mate waarin de verschillende bedrijfssectoren gebruik maken van ESF 3 subsidies ter ondersteuning van hun scholingsbeleid.

Daarna wordt in hoofdstuk 4 ingegaan op de effectiviteit van scholing. Hierbij wordt zowel ingegaan op de rol die scholing speelt bij het verwerven van bepaalde competenties, als op de relatie tussen scholing en het behoud van werk,

Ten slotte wordt in de hoofdstukken 5 en 6 ingegaan op de specifieke doelgroepen voor het scholingsbeleid. Eerst wordt in hoofdstuk 5 de positie van enkele specifieke mogelijke doelgroepen voor het scholingsbeleid nader belicht: jongeren, ouderen, vrouwen, lager opgeleiden en etnische minderheden. Daarna wordt in hoofdstuk 6 voor iedere bedrijfssector een risicoprofiel geschetst. Ten slotte worden de belangrijkste doelgroepen van het scholingsbeleid in kaart gebracht aan de hand van de risico's op competentieveroudering en de deelname aan scholingsactiviteiten.

\section{Belastende arbeidsomstandigheden}

Ondanks de toenemende aandacht voor de arbeidsomstandigheden waarmee werkenden geconfronteerd worden is ziekte of arbeidsongeschiktheid toch nog vaak het directe gevolg van het langdurig blootgesteld zijn aan belastende arbeidsomstandigheden. Daarbij kan het gaan om fysiek belastende arbeidsomstandigheden, zoals bijvoorbeeld het regelmatig kracht moeten zetten, het werken in een lawaaierige omgeving of het regelmatig blootstaan aan trilling die veroorzaakt wordt door de machines waarmee het werk wordt uitgevoerd. Daarnaast kunnen bepaalde arbeidsomstandigheden psychisch belastend zijn. Met name het regelmatig moeten werken onder een hoge tijdsdruk kan leiden tot een grote psychische belasting van werkenden. Deze belasting kan stress of burnout veroorzaken en daarmee het risico op verlies van werk vergroten.

In welke bedrijfssectoren zijn de risico's op competentieveroudering door belastende arbeidsomstandigheden nu het grootst? De fysieke belasting is, net als in vorige jaren, het hoogst in de bouwsector. Ook in de metalektro en in de landbouw en visserij is er sprake van sterk fysiek belastende arbeidsomstandigheden. In deze sectoren zijn het met name de werkenden in de technische beroepen die sterk worden geconfronteerd met fysiek belastende arbeidsomstandigheden. Daarnaast hebben veel verpleeghulpen en ziekenverzorgenden in de gezondheidszorg te maken met fysieke belasting tijdens het werk. Fysieke belasting komt overigens het meeste voor bij laagopgeleide werkenden met een technische opleiding. Daarnaast worden ook werkenden met een MBO-opleiding, dienstverlening of gezondheidszorg 
regelmatig geconfronteerd met fysiek belastend werk. Wellicht mede als gevolg van de wat ruimere arbeidsmarkt en de minder goede economische omstandigheden is de psychische belasting de laatste paar jaar iets afgenomen. Toch speelt tijdsdruk in bepaalde sectoren nog steeds een prominente rol. Zo werkt in de transportsector en de kwartaire diensten bijna één op drie werkenden onder een hoge tijdsdruk. Daarnaast hebben diegenen die werkzaam zijn in het bank- en verzekeringswezen regelmatig te maken met psychische belasting doordat ze regelmatig onder een hoge tijdsdruk moeten werken. Het gaat in de transportsector vooral om vliegers, scheepskapiteins en leidinggevenden. In de kwartaire diensten worden vooral journalisten en kunstenaars regelmatig geconfronteerd met een hoge tijdsdruk. Ook juristen en managers vormen in bepaalde sectoren risicogroepen doordat ze tijdens hun werk regelmatig met hoge tijdsdruk in aanraking komen. In de meeste bedrijfssectoren komen met name hoogopgeleiden regelmatig in aanraking met een hoge tijdsdruk tijdens het werk. In de transportsector is het beeld wat afwijkend: hier zijn het met name middelbaar of lager opgeleiden die geconfronteerd worden met een hoge tijdsdruk.

Naast het regelmatig moeten werken onder een hoge tijdsdruk kan belasting ook het gevolg zijn van de aantasting van het gevoel van "sociale veiligheid". Dit doet zich voor bij intimidatie, ongewenste sexuele aandacht of lichamelijk geweld. Daarbij kan er nog een onderscheid gemaakt worden naar agressief gedrag van klanten of patiënten en agressief gedrag van collega's of chefs. Werkenden in de kwartaire diensten, waaronder ook de gezondheidszorg valt, hebben het meest te maken met agressief gedrag van klanten of patiënten. Op enige afstand volgen de sectoren handel en horeca. In deze sectoren worden werknemers in beroepen als verkoper, winkelier en diegenen met een dienstverlenend of verzorgend beroep relatief vaak slachtoffer van agressief gedrag. Agressief gedrag van chefs of collega's komt het meeste voor in de chemie en in het bank- en verzekeringswezen.

Wanneer er zowel onder tijdsdruk als regelmatig met een beeldscherm gewerkt moet worden, vergroot dat de kans op RSI. In de sector bank- en verzekeringswezen wordt het meeste beeldschermwerk verricht, en aangezien werkenden in deze sector ook regelmatig te maken krijgen met een hoge tijdsdruk, is het risico op verlies van werk als gevolg van RSI relatief hoog. Voor de sectoren horeca en zakelijke dienstverlening en overheid en onderwijs geldt dit ook, zij het in mindere mate. Programmeurs en systeemanalisten worden logischerwijze het meest met beeldschermwerk geconfronteerd. In de handel lopen deze werknemers een groot risico op verlies van werk door RSI aangezien er zowel sprake is van regelmatig beeldschermwerk als een hoge tijdsdruk. Binnen het bank- en verzekeringswezen zijn het vooral de juristen die zowel met regelmatig beeldschermwerk als hoge tijdsdruk geconfronteerd worden. In de zakelijke dienstverlening zijn het de accountants die een hoog risico lopen door de combinatie van regelmatig beeldschermwerk met een hoge tijdsdruk. Hetzelfde geldt voor journalisten in de grafische industrie en productieplanners in de transportsector. HBO-informatici worden vooral in het banken verzekeringswezen geconfronteerd met beeldschermwerk en een hoge tijdsdruk. 


\section{Technologische en organisatorische ontwikkelingen}

Technologische en organisatorische ontwikkelingen hebben een grote invloed op het werk en de organisatie daarvan. Ze vragen om veranderingen in de manier van werken, veranderingen in de organisatie en leiden ertoe dat er voortdurend aandacht moet zijn voor kennis en vaardigheden die up-to-date zijn. Ondanks dat veel bedrijfssectoren en beroepen ingrijpend veranderen als gevolg van technologische en organisatorische ontwikkelingen, spelen die veranderingen niet overal een even belangrijke rol. De verschillen die er op dit punt tussen bedrijfssectoren bestaan kunnen verhelderd worden door gebruik te maken van een index, waarin acht verschillende indicatoren die bepaalde aspecten van technologische of organisatorische vernieuwingen verwerkt zijn. Gebruikmakend van deze index blijkt het banken verzekeringswezen eruit te springen op het vlak van technologische en organisatorische veranderingen: er zijn ingrijpende wijzigingen in de dienstverlening, relatief veel fusies, overnames en interne reorganisaties en ingrijpende procesvernieuwingen. Aangezien dit nog gecombineerd wordt met een sterke mate van informatisering zijn de risico's op competentieveroudering door technologische en organisatorische ontwikkelingen in het bank- en verzekeringswezen volop aanwezig. Een tweede sector die sterk beïnvloed wordt door organisatorische en technologische verandering is de sector overheid en onderwijs. In deze publieke sector worden de meeste procesvernieuwingen doorgevoerd die vooral gericht zijn op planmatiger werken, kwaliteitszorg en veiligheid en informatieverstrekking en communicatie via netwerken. Ook is er relatief vaak sprake van reorganisaties en ingrijpende veranderingen in het dienstenpakket.

\section{Ontwikkelingen in de structuur van de werkgelegenheid}

De minder goede economische omstandigheden van de laatste tijd hebben tot gevolg dat de werkgelegenheid momenteel in verschillende sectoren krimpt. Ondanks het verwachte bescheiden herstel op de langere termijn zal de toekomstige groei niet in alle arbeidsmarktsegmenten even sterk merkbaar zijn. Een deel van de verschillen tussen bedrijfssectoren kan verklaard worden door een voortschrijdende verschuiving van de werkgelegenheid van de industriële sectoren naar de dienstverlening. Voor zeven van de in totaal 13 bedrijfssectoren wordt er op de middellange termijn een krimpende werkgelegenheid verwacht. De totale werkgelegenheid zal naar verwachting afnemen in de landbouw en visserij, de voedingssector, de chemie, de metalektro, de overige industrie, de bouw en de sector transport en communicatie. Vooral werkenden in agrarische, technische of transportberoepen lopen daarom de komende jaren het risico hun werk door werkgelegenheidsontwikkelingen te verliezen. Dit vertaalt zich vooral in een werkgelegenheidskrimp voor werkenden met alleen basisonderwijs of een VMBO-opleiding.

\section{Verschuivingen in de gevraagde competenties}

In wezen zijn de verschuivingen in de structuur van de werkgelegenheid het gevolg van verschuivingen in de gevraagde competenties. Om zicht te krijgen op welke soort competenties belangrijker dan wel minder belangrijk worden, is er in hoofdstuk 
2 gekeken naar de mate waarin het belang van bepaalde competenties toe- of afneemt. De toename in het niveau van de gevraagde competenties is het grootst in de landbouw en visserij, de energiesector en de overige industrie. In de meeste bedrijfssectoren is het belang van de vakkennis en het toepassen van vakkennis in de praktijk toegenomen. Daanaast wordt er in bepaalde sectoren ook steeds meer belang gehecht aan algemene vaardigheden. Zo is in de transport en communicatie het belang van communicatieve vaardigheden toegenomen. In de sector overheid en onderwijs nemen plannen en organiseren, het kunnen werken in teamverband en nauwkeurigheid in belang toe.

\section{Risico's in de dienstverlenende en kantoorberoepen}

Uit het overzicht van de verschillende risico's op verlies van werk komt duidelijk naar voren dat niet alleen de werkenden in de lagere functies het risico lopen dat ze zich op een bepaald moment niet meer in hun functies kunnen handhaven. Met name in de dienstverlenende beroepen en de 'kantoorberoepen', waarin momenteel het grootste deel van de beroepsbevolking werkzaam is, zijn er verschillende risicofactoren die tot vroegtijdige arbeidsmarktuitstroom kunnen leiden. De werkenden in de dienstverlenende beroepen worden vaak geconfronteerd met de risico's van tijdsdruk en agressief gedrag van klanten terwijl de kantoorberoepen risico's lopen vanwege beeldschermwerk, tijdsdruk en de veranderingen in het werk vanwege technologische en organisatorische vernieuwingen.

\section{Scholing}

In bijna alle bedrijfssectoren is er sprake geweest van een forse teruggang in de scholingsdeelname. In de chemiesector zelfs met maar liefst 24\%-punt. Ook in de overige industrie en de handel is de daling van de scholingsdeelname fors. De afnemende scholingsparticipatie van werkenden illustreert de vaak grote conjunctuurgevoeligheid van de scholingsinvesteringen in het bedrijfsleven. Kennelijk zien veel bedrijven zich genoodzaakt bij een inzakkende bedrijvigheid sterk op hun scholingsinvesteringen te bezuinigen. Het is opmerkelijk dat de O\&O fondsen in veel sectoren nog nauwelijks tegenwicht kunnen bieden aan de sterke terugval van de scholingsinvesteringen van de bedrijven in hun sector.

Gemiddeld volgden werkenden in Nederland in de periode 2000-2002 ongeveer 0,8 cursus. Per werkende is in totaal in diezelfde periode ongeveer 11 uur aan cursussen besteed. De werkenden in de energiesector volgen gemiddeld de meeste cursussen: in twee jaar tijd wordt per werknemer bijna anderhalve cursus gevolgd. Het zijn echter de werknemers in de voedingssector en het bank- en verzekeringswezen die de meeste tijd aan cursussen hebben besteed: ruim 17 uur. De sector overheid en onderwijs volgt met gemiddeld 15,5 uur cursus per werkende. Parttimers, voor het merendeel vrouwen, nemen aanzienlijk minder deel aan cursussen.

In het algemeen zijn ICT cursussen en management en communicatiecursussen het populairst. Zo'n 10\% van de werkenden heeft in de periode 2000-2002 één of meer van deze cursussen gevolgd. In de bouwsector en de metalektro - twee sectoren 
waar de fysieke belasting hoog is - worden er relatief veel cursussen op het gebied van milieu, veiligheid en arbeidsomstandigheden gevolgd. De meeste scholing wordt door werkenden gevolgd om bij te blijven op hun vakgebied. Het is opvallend dat werknemers minder zijn gaan deelnemen aan kortere opleidingstrajecten en wat meer aan langere trajecten.

Opmerkelijk is ook dat $30 \%$ van de cursussen wordt gevolgd omdat het volgen van de opleiding verplicht is. Dit laatste geeft aan dat bijna één derde van de door werkenden gevolgde scholing wordt gevolgd zonder dat de werkende zelf duidelijk kan aangeven waarom hij of zij deze opleiding volgt. Dit duidt er op dat men waarschijnlijk weinig gemotiveerd is om de cursus te volgen. Ook wijst het er op dat werkgevers het aan hun werknemers onvoldoende duidelijk maken waarom het voor hen belangrijk is om een bepaalde training te volgen.

Het merendeel van de cursussen wordt overigens onder werktijd gevolgd. Slechts één op de vijf cursussen wordt gevolgd in de tijd van de werknemer. Dit is minder dan aan het eind van de jaren negentig. Ook de directe cursuskosten zijn voornamelijk voor rekening van de werkgever. Ruim $85 \%$ van de cursussen wordt geheel door de werkgever betaald. $10 \%$ wordt door de werknemer zelf bekostigd.

Ongeveer één op de drie bedrijven bekostigt de scholing van het personeel mede door subsidies van de scholingsfondsen. Hierbij gaat het vooral om grotere bedrijven. De risico's op verlies van werk vanwege competentieveroudering blijken in belangrijke mate richtinggevend te zijn voor de besteding van de middelen van de O\&O fondsen. Daarbij ligt er wel een duidelijk accent op het voorkomen van verlies van werk vanwege functie-inhoudelijke competentieveroudering. Alleen in de bouwsector is er meer aandacht voor scholing gericht op het verminderen van de risico's op competentieveroudering vanwege belastende arbeidsomstandigheden.

$60 \%$ van de O\&O fondsen ontwikkelt activiteiten die gericht zijn op een specifieke doelgroep. Hierbij gaat het met name om scholingsactiviteiten gericht op werkenden met een opleidingsniveau dat lager ligt dan het startkwalificatieniveau voor hun functie. Slechts $12 \%$ van de subsidies gaat uitsluitend of vooral naar bovensectorale scholing.

Er worden door de O\&O fondsen echter nauwelijks subsidies verstrekt voor scholingsactiviteiten die gericht zijn op de sectoroverstijgende mobiliteit van werkenden. Dit betekent dat werkenden die niet langer productief inzetbaar zijn in de eigen sector vanwege competentieveroudering door belastende arbeidsomstandigheden of een krimpende werkgelegenheid, slechts in zeer beperkte mate door subsidies van de O\&O fondsen in staat worden gesteld zich om te scholen voor een mogelijke baan in een andere bedrijfssector.

De O\&O fondsen, die meestal een op de bedrijven in de sector gericht vraaggestuurd beleid voeren, worden ook vrijwel niet geconfronteerd met een vraag naar sectoroverstijgende scholingsactiviteiten. Kennelijk worden bedrijven onvoldoende geprikkeld om hun personeel dergelijke scholing aan te bieden. O\&O fondsen 
zouden op dit punt een belangrijke rol kunnen spelen door het aangaan van sectoroverstijgende samenwerkingsverbanden, of men zou er toe moeten overgaan de vraaggestuurde financiering van scholingsactiviteiten ook via de individuele werknemer te laten lopen. Een opvallend initiatief in dit verband is het recente experiment met de 'employability-vouchers' van de Stichting $\mathrm{A}+\mathrm{O}$ voor werknemers in de metalektro.

Hoewel 53 O\&O fondsen zijn gemandateerd om ESF 3 subsidies aan te vragen is het aantal O\&O fondsen dat hiervan gebruik maakt tot op heden nog beperkt, al is het aantal subsidie-aanvragen de laatste tijd sterk toegenomen. Met name de private cofinancieringseis vormt nogal eens een drempel. Omdat de fondsen onderdeel zijn van algemeen verbindend verklaarde CAO's, wordt het geld dat O\&O fondsen en andere sociale fondsen beschikbaar hebben voor de bekostiging van scholingsactiviteiten door de Europese Commissie als publiek geld beschouwd dat niet als private cofinanciering kan worden ingezet. Naast de cofinancieringseisen maken de administratieve verplichtingen het zeker voor het MKB moeilijk om aanvragen in te dienen.

Uit gesprekken met O\&O fondsen blijkt overigens wel dat de ESF subsidies in een aantal sectoren een nuttige rol kunnen vervullen voor het enigszins op peil houden van de scholingsactiviteiten in de huidige recessieperiode. De tot op heden verleende ESF subsidies blijken echter vooral te worden ingezet voor scholingsactiviteiten die gericht zijn op het voorkomen van competentieveroudering waardoor mensen niet meer goed zouden kunnen functioneren in hun huidige functie. Hoewel er enkele subsidieaanvragen gericht op sectoroverstijgende scholing en mobiliteit zijn ingediend, is er over het algemeen nog weinig structureel aandacht voor de omscholing van werkenden die zich vanwege competentieveroudering niet meer in hun huidige sector kunnen handhaven. Zoals gezegd, is dit in belangrijke mate het gevolg van het feit dat de O\&O fondsen een op de bedrijven in hun sector gericht vraaggestuurd beleid voeren, waardoor ze ook vrijwel niet geconfronteerd worden met een vraag naar sectoroverstijgende scholingsactiviteiten. Daarom zou overwogen kunnen worden om de beschikbare Europese subsidies vaker aan te wenden voor het bekostigen van scholingsactiviteiten waarvoor individuele werknemers zelf het initiatief nemen. Dit zou een belangrijke bijdrage kunnen leveren aan het vergroten van de sectoroverstijgende employability van werknemers die zich binnen hun eigen sector niet langer op de arbeidsmarkt kunnen handhaven vanwege belastende arbeidsomstandigheden, organisatorische en technologische ontwikkelingen of de verschuivingen in de werkgelegenheidsstructuur.

Aan het eind van hoofdstuk 3 wordt in 13 sectorprofielen een kort overzicht gegeven van de scholingsparticipatie, de specifieke risico's op verlies van werk vanwege competentieveroudering en de mate waarin de desbetreffende sector gebruik maakt van ESF 3 subsidies voor scholingsactiviteiten die deze risico's zouden kunnen verminderen. 


\section{De effectiviteit van scholingsinspanningen}

Het volgen van algemeen gerichte cursussen blijkt het meeste bij te dragen aan de competentieontwikkeling van werkenden. Het volgen van scholing levert ook een bijdrage aan het verminderen van het risico van verlies van werk door competentieveroudering. Zo blijkt bijvoorbeeld dat werknemers die geconfronteerd worden met fysiek of psychisch belastende arbeidsomstandigheden beter in staat te zijn zich te handhaven op de arbeidsmarkt wanneer ze deelnemen aan scholingsactiviteiten. Ook meer in het algemeen blijkt het volgen van scholing de risico's op verlies van werk vanwege competentieveroudering duidelijk te verminderen.

Het leren op de werkplek blijkt ook een rol te spelen bij het verminderen van het risico van verlies van werk. Het langdurig werkzaam zijn in dezelfde functie vergroot echter op de lange termijn het risico op verlies van werk. Wanneer iemand circa 19 jaar dezelfde functie heeft uitgeoefend, stijgt het risico op verlies van werk ondanks het feit dat deze werknemers door hun lange arbeidsrelatie met hun werkgever doorgaans een relatief sterke rechtspositie hebben. Het is opmerkelijk dat deze 'ervaringsconcentratie' er reeds 6 jaar eerder toe leidt dat iemand minder vaak scholing gaat volgen. Het afhaken met het op peil houden van iemands competenties is daarmee een duidelijke voorbode voor het verlies van werk vanwege competentieveroudering.

Opmerkelijk is ook dat de werkenden die zelf aangeven dat ze met een competentietekort kampen, niet vaker daadwerkelijk hun baan verliezen. Dit is waarschijnlijk het gevolg van het feit dat werkenden die zelf een competentietekort ervaren vaker aanvullende scholing gaan volgen. Ook wanneer werknemers toch hun baan verliezen, speelt scholing een belangrijke rol. Degenen die meer scholing hebben gevolgd, hoeven namelijk minder snel uit te wijken naar een slechtere baan.

Wanneer de gegevens met betrekking tot scholingsparticipatie en de effectiviteit daarvan in termen van de opbouw van competenties met elkaar gecombineerd worden ontstaat er een indicator van de mate waarin er in de verschillende bedrijfssectoren sprake is van effectieve scholing. De effectiviteit van de scholingsinspanningen blijkt het grootst in het bank- en verzekeringswezen, de sector energie en de sector overheid en onderwijs. In de laatste sector draagt vooral het volgen van IT cursussen bij aan de competentieontwikkeling van de werkenden. In de transport en communicatie, de landbouw en visserij en de handel blijkt er in veel mindere mate sprake te zijn van effectieve scholing.

\section{Groepen met een achterstand}

In hoeverre hebben bepaalde groepen, zoals oudere werknemers, jongeren, vrouwen en etnische minderheden, een groter risico op competentieveroudering? In de eerste plaats kan er worden gekeken naar de mate waarin door deze groepen werkenden er veel fysiek of psychisch belastend werk wordt verricht. Zo zijn jongeren wat vaker werkzaam in fysiek belastende functies. Daarbij gaat het vooral om functies waarin er regelmatig kracht moeten worden gezet. Vooral in de chemie, de 
metalektro, de overige industrie, het bank- en verzekeringswezen en de sector overheid en onderwijs verrichten jongeren veel fysiek belastend werk. Voor ouderen is de fysieke belasting groter dan gemiddeld in de chemie, de handel, de banksector en in de kwartaire diensten.

De fysieke belasting voor vrouwen ligt gemiddeld iets lager dan bij mannen, maar is hoger dan gemiddeld in de chemie, het bank en verzekeringswezen, de horeca en zakelijke dienstverlening en de kwartaire diensten. Etnische minderheden hebben in de sectoren bank en verzekering, de kwartaire diensten en de chemie te maken met een meer dan gemiddelde fysieke belasting.

Wat betreft de psychische belasting valt met name de positie van oudere werknemers op. In de meeste sectoren is er bij oudere werknemers sprake van een bovengemiddelde mentale belasting. Etnische minderheden hebben in de voedingssector, de chemie de handel en in het bank- en verzekeringswezen relatief vaak te maken met een hoge psychische belasting.

Voor vrouwen is het regelmatig verrichten van beeldschermwerk een belangrijke risicofactor, omdat ze zijn oververtegenwoordigd in secretariële, administratieve en andere ondersteunende functies, die grotendeels achter een beeldscherm worden uitgeoefend. Vrouwen verrichten in veel bedrijfssectoren relatief vaak beeldschermwerk. Oudere werknemers verrichten relatief vaak beeldschermwerk in de voedingssector, de chemie en de kwartaire diensten. Jongeren komen in de overige industrie, de sector transport en communicatie en in het bank- en verzekeringswezen relatief vaak in aanraking met beeldschermwerk. Voor de allochtone werkenden is dat het geval in de sector overheid en onderwijs, het bank- en verzekeringswezen en in de transport en communicatiesector.

Er zijn ook enige verschillen in de mate waarin de onderscheiden groepen werkzaam zijn in beroepen waarin de werkgelegenheid de komende jaren naar verwachting zal krimpen. Zowel oudere werknemers als de werkenden die behoren tot een etnische minderheidsgroep zijn relatief vaak werkzaam in beroepen met een krimpende werkgelegenheid. Daarentegen zijn jongeren en vooral ook vrouwen relatief weinig werkzaam in krimpende beroepssegmenten.

Ook is nagegaan in hoeverre bepaalde groepen werkenden minder vaak participeren in scholingsactiviteiten die hun risico's op competentieveroudering kunnen voorkomen. Voor de onderzochte groepen is dat echter alleen bij de ouderen het geval. In vrijwel alle bedrijfstakken nemen ouderen relatief weinig deel aan langer durende scholingsactiviteiten. In de voedingssector, de metalektro, de sector transport en communicatie, het bank- en verzekeringswezen en de sector overheid en onderwijs zijn ouderen ook minder betrokken bij kortdurende scholingsactiviteiten.

Ook vrouwen nemen in enkele sectoren minder vaak deel aan langer durende scholingsactiviteiten. Dit is het geval in de landbouw en visserij, de voeding, de overige industrie, de bouwsector, de horeca en zakelijke dienstverlening en in de kwartaire diensten. Voor etnische minderheidsgroepen is er alleen in de energie- 
sector sprake van een minder dan gemiddelde participatie in langdurige scholingstrajecten. Allochtonen die werkzaam zijn in de commerciële of niet-commerciële dienstverlening participeren minder vaak in kortlopende scholingsactiviteiten.

In het laatste hoofdstuk van het rapport wordt er uitgebreid stilgestaan bij doelgroepen voor het scholingsbeleid en de kansrijke scholingstrajecten voor die doelgroepen. Allereerst wordt er voor elke bedrijfssector een risicoprofiel geschetst, dat een overzicht geeft van de verschillende risico's op competentieveroudering en de scholingsdeelname. Voor een overzicht van die profielen wordt er verwezen naar figuur 6.1 .

Daarna volgen de doelgroepen voor het scholingsbeleid. Dit zijn de beroepsgroepen die momenteel grote risico's op competentieveroudering lopen, mede omdat hier onvoldoende op wordt ingespeeld door het volgen van de gewenste bij- of omscholing. De meeste doelgroepen voor het scholingsbeleid hebben te maken met één van de volgende risicofactoren: beeldschermwerken tijdsdruk, fysieke belasting of een krimpende werkgelegenheid. Tabel 6.1 geeft voor alle doelgroepen een uitgebreid overzicht van de risicofactoren waarmee ze geconfronteerd worden.

Vervolgens komen de kansrijke scholingstrajecten aan de orde die de werkenden in de verschillende doelgroepen een beter perspectief op behoud van werk kunnen geven, wanneer ze zich niet meer in hun functie kunnen handhaven. Daarbij kan er sprake zijn van zowel niveauverhogende, richtingveranderende als sectoroverstijgende scholingstrajecten, of een combinatie daarvan. In tabel 6.2 wordt een overzicht gegeven van de scholingstrajecten die de verschillende doelgroepen perspectief zouden kunnen bieden op behoud van werk als zij zich niet meer in hun huidige functie kunnen handhaven. Opvallend is dat veel van deze scholingstrajecten een sectoroverstijgend karakter hebben. Sectoroverstijgende scholing lijkt daarmee een belangrijk instrument te zijn voor het bestrijden van competentieveroudering. Daardoor kan het een belangrijke rol spelen in het verhogen van de arbeidsparticipatie. 


\section{Inleiding}

Het Lissabon akkoord van de Europese Raad heeft het belang van de scholing van werkenden hoog op de politieke agenda geplaatst. Niet alleen is het voor een dynamische kenniseconomie cruciaal dat het overgrote deel van de beroepsbevolking beschikt over een startkwalificatie voor de arbeidsmarkt en er voor zorgt dat haar competenties up-to-date blijven en verder worden ontwikkeld. Ook is een grotere aandacht voor "een leven lang leren" cruciaal voor het verhogen van de arbeidsparticipatie van met name 50+'ers. Hierbij gaat het primair om het voorkomen van arbeidsmarktuittrede als gevolg van een of andere vorm van competentieveroudering.

Werkgelegenheid en scholing zijn immers twee sterk aan elkaar gerelateerde begrippen. Een goede vooropleiding biedt een goed perspectief op de arbeidsmarkt en een grotere werkzekerheid. Waar vroeger echter een goede vooropleiding werknemers al voldoende in staat stelde om lange tijd goed te functioneren op de arbeidsmarkt, is dat tegenwoordig nauwelijks nog denkbaar. Het belang van postinitiële scholing is om uiteenlopende redenen de laatste decennia sterk toegenomen. De belangrijkste oorzaken zijn de elkaar vaak snel opvolgende technologische en organisatorische vernieuwingen, zoals automatisering, informatisering, de ontwikkeling van nieuwe producten en diensten, reorganisaties en fusies. Deze vernieuwingen leiden, in combinatie met elkaar, tot veranderingen in de taken en functies van werknemers, waardoor er belangrijke verschuivingen optreden in de voor een adequate functievervulling vereiste competenties. ${ }^{1}$ Veranderingen in het takenpakket van de functie die iemand uitoefent maken het noodzakelijk om iemands competenties voortdurend up-to-date te houden (te upgraden). ${ }^{2}$ Ingrijpende veranderingen kunnen zelfs zorgen voor het vervallen van een deel van het takenpakket van een functie of het ontstaan van nieuwe functies. Zeker als functies of zelfs beroepen geheel of gedeeltelijk dreigen te verdwijnen, waardoor bepaalde competenties niet of nauwelijks meer gevraagd worden, vormt (om)scholing dé manier voor werknemers om op de arbeidsmarkt actief te blijven en werkloosheid te voorkomen.

Niet alleen technologische en organisatorische vernieuwingen en veranderingen maken scholing echter noodzakelijk. Postinitiële scholing is vaak ook van groot belang, omdat de fysieke en psychische belasting van het werk in bepaalde beroepen dusdanig hoog is dat het vrijwel onmogelijk is dat mensen hun gehele arbeidsloopbaan in deze beroepen blijven werken. Omscholing speelt in dat geval meestal een cruciale rol bij het voorkomen van werkloosheid of vroegtijdige uitstroom

1. D. Bell, (1974), De komst van de postindustriële samenleving. Een sociale toekomstverkenning, Deventer: Kluwer.

P. den Boer en B. Hövels (2002), Technologie en veranderingen in competentie-eisen, In: R. Batenburg, et al. (red.), Arbeid en ICT in onderzoek, Utrecht: Lemma.

2. L. Borghans en B.J. ter Weel (2003), ICT en de organisatie van werk in Nederland, 19882000, in: Ester, P., Fouarge, D., Kerkhofs, M. en Román, A. (red.), ICT, Arbeid en Organisatie, Den Haag: Reed Business Information, pp. 59-83. 
uit de arbeidsmarkt. Scholing is echter ook een belangrijk middel om ervoor te zorgen dat het moment waarop werknemers die fysieke belasting niet meer aan kunnen zolang mogelijk uit wordt gesteld. Bijvoorbeeld door werknemers te leren om zo veilig mogelijk en in een juiste houding te werken. Dergelijke scholing aangevuld met de omscholing van mensen die zich niet langer in hun huidige functie kunnen handhaven is van groot belang om mensen in staat te stellen langer aan het werk te blijven en daarmee de instroom in de WAO en pre-pensioneringsregelingen te verminderen.

Vooral in tijden waarin de economie wat minder draait, zoals de laatste jaren het geval is, is het belangrijk dat de overheid een goed overzicht heeft van de risico's op verlies van werk die verschillende groepen werkenden lopen. Daarvoor is in de eerste plaats inzicht vereist in de factoren die het risico van het geheel of gedeeltelijk verlies van werk veroorzaken: belastende arbeidsomstandigheden, technologische en organisatorische vernieuwingen en verschuivingen in de werkgelegenheidsstructuur. Daarnaast is inzicht vereist in de mate waarin de verschillende groepen werkenden zich wapenen tegen de risico's die ze lopen op verlies van werk vanwege competentieveroudering, alsmede inzicht in de mate waarin bedrijven en instellingen hun personeel ook de mogelijkheid bieden zich te wapenen tegen deze risicofactoren door middel van aanvullende scholing.

Wanneer sociale partners en de overheid over goede informatie beschikken, kan een op de juiste doelgroepen en risicofactoren gericht scholingsbeleid voorkomen dat grote aantallen werknemers tijdelijk of zelfs permanent verloren gaan voor de arbeidsmarkt en in de uitkeringssfeer belanden. Om in de voor een dergelijk scholingsbeleid benodigde informatie te voorzien, brengt het Researchcentrum voor Onderwijs en Arbeidsmarkt (ROA) al sinds 1996 in opdracht van het Ministerie van Sociale Zaken en Werkgelegenheid de risico's van verlies van werk als gevolg van competentieveroudering én de scholingsinspanningen om die risico's te beperken in kaart. Dit doet ROA binnen het raamwerk van het door het Ministerie opgezette Werkgelegenheids- en Scholingsobservatorium (WSO).

De resultaten van het WSO zijn in de afgelopen jaren niet alleen van belang gebleken voor het Ministerie van Sociale Zaken en Werkgelegenheid, maar ook voor het scholingsbeleid van bedrijven en branches. De resultaten van het WSO hebben de bewustwording van de risico's op competentieveroudering vergroot. Ten slotte kan WSO een richtinggevende functie vervullen als het gaat om de inzet van scholingsmiddelen uit het Europese Sociale Fonds (ESF). In de periode 2000-2006 worden ESF-middelen ondermeer ingezet voor een activerend arbeidsmarktbeleid. Daartoe behoort vooral scholing van werkenden en werkzoekenden tot op het niveau van de startkwalificatie. Maar ook verdere opscholing tot op het niveau van een vakof middenkaderopleiding en bedrijfstakoverstijgende scholing zijn subsidiabel.

Het WSO heeft tot doel risico's op competentieveroudering in beeld te brengen en deze te relateren aan de scholingsdeelname van werkenden. De centrale vraagstelling kan als volgt worden verwoord: 
Welke rol kan de scholing van werkenden spelen om de risico's op verlies van werk vanwege de verschuivingen in de gevraagde competenties te verminderen?

Deze vraagstelling heeft betrekking op de volgende drie hoofdvragen:

1) Hoe ontwikkelt de vraag naar competenties zich, naar bedrijfssector en beroep?

2) Welke groepen werkenden lopen als gevolg van competentieveroudering het risico hun werk te verliezen?

3) Welke scholingsactiviteiten gedurende de loopbaan dragen bij aan het behoud van werk?

De opzet van het rapport wijkt echter enigszins af van de vorige rapportages. In eerdere rapportages van het WSO werd er relatief veel aandacht besteed aan het beantwoorden van de eerste twee vragen. Dit keer staat daarentegen vooral de derde vraag centraal: In hoeverre dragen de scholingsactiviteiten van werknemers bij aan het behoud van werk?

Voor deze accentverschuiving is gekozen om twee belangrijke redenen. Allereerst is de Nederlandse arbeidsmarkt als gevolg van de economische recessie de laatste jaren ingrijpend veranderd. Het grote tekort aan personeel in het begin van het tweede millennium heeft in relatief korte tijd op verschillende segmenten van de arbeidsmarkt weer plaatsgemaakt voor een personeelsoverschot. Daarbij is er vooral ook sprake van een snel toenemende (jeugd)werkloosheid. In dat kader is het van belang om meer dan in voorgaande jaren de aandacht te richten op de betekenis van scholing voor het actief kunnen blijven op de arbeidsmarkt. In de tweede plaats is er zowel binnen bedrijven, instellingen als in het overheidsbeleid een toenemend besef van het belang van het 'competentiedenken'. In dat licht is het zinvol om de relatie tussen postinitiële scholing en de veroudering van competenties nader te analyseren.

\section{Competentieveroudering en de rol van scholing}

Competentieveroudering kan op twee manieren plaatsvinden, die we kunnen aanduiden als technische veroudering en economische veroudering. ${ }^{3} \mathrm{Er}$ is sprake van technische competentieveroudering als iemands fysieke of mentale capaciteiten afnemen. Er bestaan twee vormen van technische competentieveroudering: slijtage en atrofie. Bij slijtage gaat het om de waardevermindering van menselijk kapitaal door ziekte, het natuurlijk ouderwordingsproces of letsel. Als werkenden fysiek niet meer in staat zijn om bepaalde taken adequaat uit te oefenen, dan is sprake van competentieveroudering als gevolg van slijtage. Dit is bijvoorbeeld het geval wanneer een metselaar vanwege ernstige rugklachten niet langer in staat is als metselaar te werken. Werknemers die kampen met slijtage van hun competenties kunnen niet meer (voldoende) productief in hun functie worden ingezet met als gevolg een verslechterende arbeidsmarktpositie en een verhoogd risico op verlies van werk.

3. A. de Grip en J.B. van Loo (2002), The Economics of Skills Obsolescence: A Review. In: A. de Grip, J.B. van Loo en K. Mayhew (eds), The Economics of Skills Obsolescence, Research in Labor Economics, 21, JAI Press, pp. 1-26. 
Slijtage hangt in belangrijke mate samen met de mate waarin er gewerkt wordt onder belastende arbeidsomstandigheden. Daarbij is zowel de fysieke als mentale belasting tijdens het werk van invloed. ${ }^{4}$

Er is sprake van atrofie wanneer de competenties waarover werkenden aan het begin van hun loopbaan beschikken verloren gaan, omdat men deze competenties lange tijd niet of in onvoldoende mate gebruikt. Atrofie komt bijvoorbeeld voor wanneer vrouwen zich een aantal jaren terugtrekken van de arbeidsmarkt voor de verzorging van hun kinderen, of wanneer werkenden zich in hun loopbaan steeds verder gaan specialiseren, waardoor ze nog slechts zeer beperkt inzetbaar zijn.

Bij economische competentieveroudering gaat het om een waardedaling van het menselijk kapitaal als gevolg van veranderingen van buitenaf. Technologische vernieuwingen zorgen ervoor dat bedrijven hun manier van werken aanpassen waardoor veranderingen optreden in de competentievereisten voor verschillende functies. ${ }^{5}$ Wanneer de veranderingen ingrijpend zijn kan het zelfs zo zijn dat er voor bepaalde functies geheel andere competenties worden gevraagd dan in het verleden, waardoor het opleidingsniveau van degenen die deze functies uitoefenen niet langer toereikend zijn. In dat geval is er sprake van een substantiële upgrading van de opleidingseisen. Veranderingen in de voor een bepaalde functie gevraagde competenties kunnen tot gevolg hebben dat werknemers zonder extra scholingsinspanningen niet langer kunnen voldoen aan de veranderende of hogere eisen van hun functie. In dat geval is sprake van functie-inhoudelijke competentieveroudering.

Een tweede vorm van economische competentieveroudering doet zich voor wanneer een werkende van bedrijf moet veranderen, bijvoorbeeld wanneer taken door het vroegere bedrijf zijn uitbesteed of wanneer een werkende als gevolg van een interne reorganisatie wordt ontslagen. Het veranderen van werkgever gaat vrijwel altijd gepaard met bedrijfsspecifieke competentieveroudering. Dat deel van het menselijk kapitaal dat bedrijfsspecifiek is (kennis van communicatielijnen, klanten, interne cultuur of reglementen) gaat verloren. Een dergelijke bedrijfsspecifieke competentieveroudering doet zich vooral voor wanneer er bij reorganisaties of bedrijfssluitingen mensen worden ontslagen die weer op zoek moeten gaan naar een verwante functie in een ander bedrijf. ${ }^{6}$

4. J.B. van Loo, A. de Grip en M. de Steur (2001), Skills obsolescence: causes and cures, International Journal of Manpower, 22, pp. 121-137.

5. B.J. ter Weel (2002), The Computerization of the Labour Market, Proefschrift Universiteit Maastricht, Maastricht.

A. de Grip (2001), Dynamiek op de Arbeidsmarkt en de Employability van Werkenden, Tijdschrift voor Arbeidsvraagstukken, 17, pp. 213-221.

E. Wolff (2000), Technology and the demand for skills, in: L. Borghans, en A. de Grip (red.), The Overeducated Worker? The Economics of Skill Utilization. Cheltenham: Edward Elgar, pp. 27-56.

6. B. Kriechel (2003), Heterogeneity among Displaced Workers. Proefschrift Universiteit Maastricht, Maastricht. 
De laatste vorm van competentieveroudering doet zich voor wanneer verschuivingen in de werkgelegenheid ervoor zorgen dat die competenties waarover iemand beschikt niet meer gevraagd worden. De introductie van de pinautomaat en het internetbankieren heeft er bijvoorbeeld voor gezorgd dat de vraag naar bepaalde competenties van kasmedewerkers bij banken flink af is genomen. In dat geval spreken we van competentieveroudering vanwege verschuivingen in de werkgelegenheidsstructuur.

Het voorbeeld van de kasmedewerkers illustreert de raakvlakken tussen de verschillende vormen van competentieveroudering. Door de introductie van de pinautomaat en het internetbankieren worden kasmedewerkers bij banken geconfronteerd met competentieveroudering vanwege verschuivingen in de werkgelegenheidsstructuur. De vraag naar de bij hen aanwezige competenties om geld te verstrekken, over te boeken en dergelijke neemt immers sterk af. Zelfs zo sterk dat het risico van verlies van werk voor deze groep erg groot wordt. De introductie van het internetbankieren zorgt echter ook voor functie-inhoudelijke competentieveroudering bij bijvoorbeeld webmasters van banken of helpdesk medewerkers. Doordat de inhoud van hun functies verandert om het internetbankieren goed te laten functioneren, veranderen ook de vereiste competenties. Het toenemend gebruik van computers in het werk leidt ten slotte voor grote groepen werkenden tot vormen van RSI (Repetitive Strain Injuries). RSI, hoewel zeker niet alleen een gevolg van langdurig computerwerk, lijkt zelfs te zijn uitgegroeid tot één van de belangrijkste werkgerelateerde oorzaken van ziekteverzuim. ${ }^{7}$ Reden genoeg om aan te nemen dat ontwikkelingen op informatietechnologisch gebied, zoals de toename van het gebruik van internet, ook tot technische competentieveroudering in de vorm van slijtage kunnen leiden.

In tabel 1.1 wordt een overzicht gegeven van de verschillende vormen van competentieveroudering. Bovendien wordt telkens aangegeven welke factoren het risico van competentieveroudering kunnen versterken en wat het karakter van de scholing zou moeten zijn die het risico op verlies van werk als gevolg van de desbetreffende vorm van competentieveroudering zou kunnen beperken.

Wanneer competentieveroudering zich voordoet ontstaat ook het risico dat iemand zich niet langer op de arbeidsmarkt weet te handhaven. Bij waardevermindering van iemands menselijk kapitaal als gevolg van slijtage - een werknemer kan bijvoorbeeld geen zware spullen meer tillen - is verandering van de inhoud van het werk of aanpassing van de werkplek soms een goed middel om verlies van werk te voorkomen. In veel gevallen is een dergelijke aanpassing echter niet goed mogelijk, waardoor de werknemer op den duur te kampen krijgt met onherstelbare gezondheidsschade. Bijvoorbeeld als een werknemer door de rug is gegaan en helemaal niet meer mag tillen. In dat geval is omscholing naar een ander beroep de enige weg

7. I. Houtman, F. Otten en A. Venema (2003), Kerncijfers arbeid, gezondheid en sociale zekerheid, in: I.L.D. Houtman, P.G.W. Smulders en D.J. Klein Hesselink (red.) (2001), Trends in Arbeid 2002, TNO Arbeid/Kluwer, pp. 69-101. 


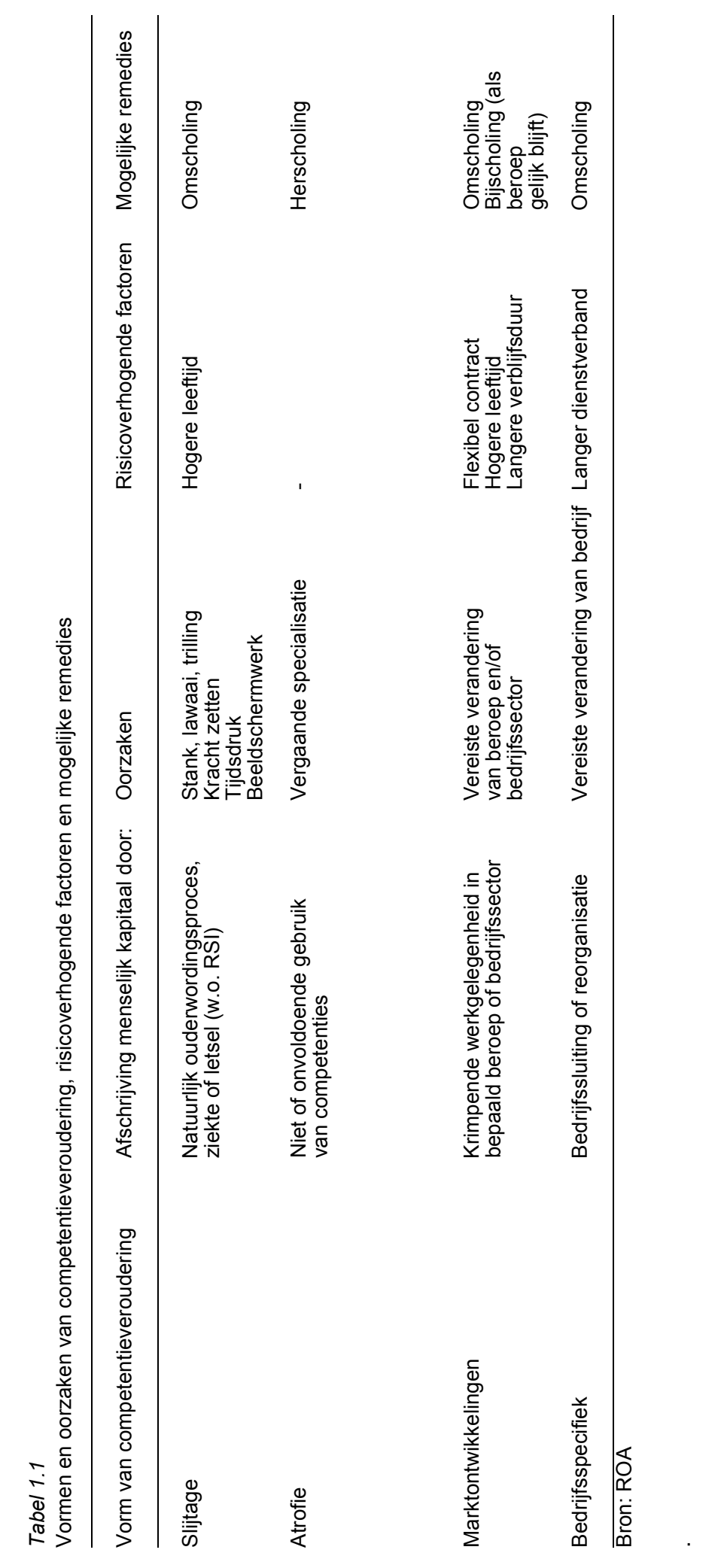


om verlies van werk te voorkomen. Omscholing kan dus noodzakelijk zijn wanneer slijtage optreedt. Omscholing biedt echter ook uitkomst wanneer iemand als gevolg van een krimpende werkgelegenheid zijn of haar baan kwijtraakt, zoals de kasmedewerkers en de data-entry medewerkers bij banken. Vaak zijn dan de kansen om weer werk te vinden in een soortgelijke functie immers erg klein bij een krimpende werkgelegenheid in de beroepsgroep of sector waarin iemand werkzaam is.

Atrofie is meestal goed op te lossen door gerichte herscholing of door bijscholing in de zin van opfriscursussen. Tijdens de grote arbeidsmarktkrapte van de afgelopen jaren is in verschillende sectoren veel aandacht besteed aan het reïntegreren van herintreders via speciale herintredercursussen. Dit is een zeer geschikte vorm van scholing gericht op het herstellen van de competentieveroudering die is opgetreden als gevolg van het langere tijd niet gebruiken van de competenties waarover de herintreders vroeger wel beschikten.

Functie-inhoudelijke competentieveroudering vraagt eerder om bijscholing dan om omscholing of herscholing. Bij bijscholing gaat het om het up-to-date houden, c.q. uitbouwen van iemands kennis of vaardigheden, waardoor men zich kan handhaven in de functie waarin men werkzaam is, of kan overstappen naar een soortgelijke functie.

\section{Opzet van het rapport}

Om een antwoord te kunnen geven op de hoofdvragen van het onderzoek wordt in hoofdstuk 2 van dit rapport een actueel overzicht gegeven van de verschillende oorzaken van competentieveroudering waarmee werkenden kunnen worden geconfronteerd. Daarbij wordt net als in voorgaande jaren de door het ROA ontwikkelde typologie van de verschillende mogelijke oorzaken van competentieveroudering als uitgangspunt genomen. In het Observatorium wordt dan ook ingegaan op:

- Belastende arbeidsomstandigheden;

- Technologische en organisatorische ontwikkelingen;

- Verschuivingen in de sectorale werkgelegenheidsstructuur.

De ontwikkelingen in de verschillende risico's op competentieveroudering en verlies van werk worden voor alle bedrijfssectoren in kaart gebracht. Daarbij worden op basis van verschillende databestanden geactualiseerde kerngegevens gepresenteerd. Deze informatie wordt telkens aangevuld door binnen de verschillende bedrijfssectoren een inventarisatie te maken van de belangrijkste risicogroepen. Dit op basis van de risico's van de desbetreffende vorm van competentieveroudering voor werknemers in een bepaalde beroepsgroep, of voor de werknemers met een bepaalde opleidingsachtergrond die in de sector werkzaam zijn. Ten slotte wordt in hoofdstuk 2 nader ingegaan op het karakter van de verschuivingen in de voor het werk in de verschillende bedrijfssectoren en beroepsgroepen vereiste competenties. Hierbij wordt zowel gekeken naar de verschuivingen in de gevraagde vakspecifieke competenties als naar de verschuivingen in de meer algemene competenties. 
Tegenover de risico's op competentieveroudering staat de deelname aan scholingsactiviteiten van de werkenden in de desbetreffende bedrijfssector. De groepen werkenden waarvoor de scholingsparticipatie achter blijt bij de risico's die men loopt op competentieveroudering kunnen beschouwd worden als de potentiële doelgroepen voor het scholingsbeleid gericht op behoud van werk. ${ }^{8}$ Hoofdstuk 3 is geheel gewijd aan scholingsparticipatie. In dit hoofdstuk gaat de aandacht vooral uit naar de scholingsparticipatie van werknemers in verschillende beroepen en met verschillende opleidingsachtergronden binnen bedrijfssectoren. Daarnaast wordt aandacht besteed aan het scholingsaanbod van bedrijven en instellingen in de verschillende bedrijfssectoren. In aanvulling daarop wordt nader ingegaan op de rol die sectorale opleidingsfondsen (O\&O of $A \& O$ fondsen) spelen in de verschillende bedrijfssectoren. In dit kader zal er gekeken worden in hoeverre verschillende bedrijfssectoren beschikken over opleidingsfondsen, over welke middelen deze fondsen beschikken, aan wat voor soorten scholing de middelen worden besteed en voor welke groepen de middelen worden uitgetrokken. Ten slotte wordt er ook aandacht besteed aan de mate waarin er gebruik wordt gemaakt van ESF-subsidies en de manier waarop deze subsidies worden ingezet.

Met behulp van verklarende analyses wordt in hoofdstuk 4 nader ingegaan op de effectiviteit van scholing. In eerste instantie wordt onderzocht welke rol scholing speelt bij het verwerven van bepaalde competenties. In deze analyse zal er gekeken worden naar de relatie tussen verschillende soorten cursussen en het niveau van de competenties waarover werknemers beschikken. In de tweede analyse wordt gekeken naar de relatie tussen scholing en behoud van werk. Deze relatie wordt onderzocht met behulp van verschillende opeenvolgende metingen van het OSA Arbeidsaanbodsurvey. Ten slotte wordt in dit hoofdstuk een indicatie gegeven van de mate waarin er in de verschillende bedrijfssectoren sprake is van een effectieve scholingsdeelname. In hoofdstuk 5 wordt uitgebreid stilgestaan bij de groepen die mogelijk een groter risico lopen om zich niet op de arbeidsmarkt te kunnen handhaven, of minder vaak participeren in scholingsactiviteiten. Daarbij gaat het om de specifieke problematiek van jongeren, ouderen, vrouwen, lager opgeleiden en etnische minderheden. In hoofdstuk 6 worden eerst de sectorale risicoprofielen gepresenteerd, die een overzicht geven van de risico's op verlies van werk vanwege competentieveroudering in de verschillende bedrijfssectoren. Daarna worden de belangrijkste doelgroepen voor het scholingsbeleid in kaart gebracht aan de hand van de verschillende risico's, die de werkende in de verschillende beroepsgroepen lopen (hoofdstuk 2) en de scholingsinspanningen die daar tegenover hebben gestaan (hoofdstuk 3). Daarna wordt er in dit slothoofdstuk ingegaan op de kansrijke scholingstrajecten voor de verschillende risicoberoepen. Deze scholingstrajecten hebben als doel mogelijke oplossingen aan te dragen voor de werkenden die geconfronteerd worden met competentieveroudering.

8. Zie ook: J.M.A.F. Sanders, A. de Grip en J.B. van Loo (2003), Scholing in de strijd tegen competentieveroudering, Tijdschrift voor HRM, pp. 95-115. 


\section{Risicofactoren en verschuivingen in gevraagde competenties}

\section{$2.1 \quad$ Inleiding}

Zoals in het vorige hoofdstuk al naar voren kwam, kan competentieveroudering uiteenlopende oorzaken hebben. Om de risico's van competentieveroudering in beeld te brengen, wordt er in dit hoofdstuk ingegaan op de belangrijkste risicofactoren:

- De mate waarin werknemers in hun werk worden geconfronteerd met belastende arbeidsomstandigheden.

- De mate waarin technologische en organisatorische ontwikkelingen het werk veranderen.

- Ontwikkelingen in de structuur van de werkgelegenheid die invloed hebben op het voortbestaan van bepaalde functies en banen.

Op basis van de meest recente informatie wordt er telkens eerst een overzicht gegeven van de bedrijfssectoren waarin de arbeidsomstandigheden, technologische en organisatorische ontwikkelingen en de sectorale werkgelegenheidsverschuivingen in de bedrijfssectoren een rol spelen. Vervolgens wordt er ingegaan op de beroepsgroepen en de werkenden met een bepaalde opleidingsachtergrond, die in een bepaalde bedrijfssector het meest geconfronteerd worden met de desbetreffende risicofactoren. Op deze manier ontstaat er een beeld van de groepen werkenden waarvoor de risico's op verlies van werk vanwege competentieveroudering het grootst zijn. In aanvulling hierop wordt een overzicht gegeven van de opleidingsachtergrond van de mensen die in hun werk het meeste met een bepaald risico worden geconfronteerd. Dit geeft een beeld van de doelgroepen waarop het niveau en eventueel de richting van de gewenste bij- of omscholing zou moeten worden afgestemd.

De opbouw van dit hoofdstuk is als volgt: In paragraaf 2.1 wordt de aandacht gericht op belastende arbeidsomstandigheden. Hierbij zal er achtereenvolgens worden ingegaan op de fysieke belasting en psychische belasting (tijdsdruk, sociale veiligheid) tijdens het werk en het beeldschermwerk. In paragraaf 2.2 wordt er een overzicht gegeven van de mate waarin technologische en organisatorische ontwikkelingen de inhoud van het werk kunnen veranderen, waardoor werkenden geconfronteerd kunnen worden met het verouderd raken van hun competenties. De sectorale verschuivingen in de werkgelegenheid en de mede daaraan gerelateerde verschuivingen in de beroepenstructuur van de werkgelegenheid komen in paragraaf 2.3 aan de orde. Ook wordt in deze paragraaf ingegaan op de voortschrijdende upgrading van het op de arbeidsmarkt vereiste opleidingsniveau. In paragraaf 2.4 wordt er nader ingegaan op de gevolgen die de technologische en organisatorische ontwikkelingen in de verschillende bedrijfssectoren en de sectorale verschuivingen in de werkgelegenheid kunnen hebben voor de inhoud van het werk in de verschillende 
bedrijfssectoren. Deze gevolgen zullen in kaart worden gebracht door een overzicht te geven van de verschuivingen in de gevraagde competenties in de verschillende bedrijfssectoren. Paragraaf 2.5 sluit het hoofdstuk af met de belangrijkste conclusies.

\subsection{Belastende arbeidsomstandigheden}

Ondanks het teruglopende aantal verstrekte WAO uitkeringen in 2003 gaan in Nederland gaan nog altijd veel mensen voor de arbeidsmarkt verloren door ziekte en arbeidsongeschiktheid. Van Januari 2003 tot en met Oktober 2003 werden zo'n 56.000 nieuwe WAO uitkeringen verstrekt. Eind 2003 schommelt het totaal aantal WAO uitkeringen rond de $790.000 .^{9}$ Vaak vindt ziekte of arbeidsongeschiktheid haar oorzaak op het werk. Voor een deel gaat het daarbij om bedrijfsongevallen. Bedrijven moeten de risico's hierop vanzelfsprekend zoveel mogelijk beperken. Maar misschien nog wel belangrijker zijn de dagelijkse arbeidsomstandigheden. Veel langdurige ziektegevallen worden immers veroorzaakt door regelmatige blootstelling aan fysieke of psychische belasting. Werkenden lopen hierdoor het gevaar dat zij op een gegeven moment niet langer in staat zijn hun functie uit te oefenen. Men is dan gedwongen op zoek te gaan naar andersoortig werk om zich op de arbeidsmarkt te kunnen blijven handhaven.

Arbeidsuitval vanwege ziekte leidt tot productiviteitsverlies of vervangingskosten. De kosten van ziekte zijn niet gering en zijn steeds meer voor rekening van werkgevers. De Wet Verbetering Poortwachter, die per 1 april 2002 is ingegaan, heeft er bijvoorbeeld voor gezorgd dat de werkgever een veel grotere verantwoordelijkheid heeft om er samen met de zieke werknemer voor te zorgen dat reïntegratie zo snel mogelijk plaatsvindt. Boven op de verplichting van de werkgever om het eerste ziektejaar het loon door te betalen komt de verplichting om, indien de werkgever tekortschiet in zijn reïntegratie-inspanningen, het loon van de werknemer nog eens gedurende maximaal 52 weken door te betalen. De kosten van ziekteverzuim en arbeidsongeschiktheid zijn voor de werkgever de laatste jaren flink gestegen en het is daarom niet meer dan logisch dat er de afgelopen jaren meer aandacht is gekomen voor verzuimbeheersing. Het voorkómen van verzuim neemt daardoor intussen een centrale positie in in de bedrijfsvoering van Nederlandse bedrijven en instellingen.

Steeds meer, vooral grotere, bedrijven beschikken over een door een Arbo-dienst getoetste risico-inventarisatie en -evaluatie (RI\&E) en verzuimbegeleiding vormt tegenwoordig een vast onderdeel van $99 \%$ van de contracten tussen bedrijven en instellingen en Arbo-diensten. Het spreekt voor zich dat vooral bedrijven en instellingen waar sprake is van risicovolle situaties, doordat bijvoorbeeld fysiek zwaar werk wordt verricht, met giftige stoffen wordt gewerkt of onder hoge tijdsdruk wordt gewerkt, de meeste aandacht hebben voor ARBO. De bouw en de industrie zijn

9. Uitvoering Werknemersverzekeringen UWV (2003), Maandoverzicht arbeidsongeschiktheidsuitkeringen januari 2003-oktober 2003, UWV, Amsterdam. 
bijvoorbeeld zeer actieve sectoren als het gaat om veilig werken en het voorkomen van bedrijfsongevallen. ${ }^{10}$

Anders dan in voorgaande jaren wordt er in WSO 2003 niet meer gekeken naar het percentage werkenden dat aangeeft wel eens te worden geconfronteerd met een belastingsfactor, maar uitsluitend naar het percentage werkenden dat aangeeft regelmatig te worden geconfronteerd met een bepaalde fysieke of psychische belastingsfactor. Dit omdat met name wanneer iemand regelmatig te maken heeft met een bepaalde belastingsfactor het risico op verlies van werk als gevolg van slijtage toeneemt.

Ook wordt er in dit rapport gebruik gemaakt van gemiddelde percentages werkenden over de jaren 2001 en 2002. In vorige WSO rapporten is altijd gebruik gemaakt van cijfers over één bepaald jaar. Het gebruik van gemiddelden vergroot niet alleen de betrouwbaarheid van de gegevens, maar maakt het ook mogeliijk om uitspraken te doen over een groter aantal beroepsgroepen en opleidingstypen binnen bedrijfssectoren.

\section{Fysieke belasting}

Net als in voorgaande edities van het WSO wordt de mate waarin werkenden worden geconfronteerd met fysieke belasting bepaald met behulp van een uit drie belastingsfactoren samengestelde indicator, namelijk:

- Kracht zetten;

- Werken in een lawaaiige omgeving;

- Werken met apparaten of voertuigen die lichaamstrilling veroorzaken.

Kracht zetten kan leiden tot pijnklachten in rug, nek en schouders. Het arbeidsrisico speelt in verschillende beroepsgroepen, waarvan van oudsher de bouwvakkers de bekendste is. Ook ziekenverzorgenden behoren echter al jaren tot de grootste risicogroepen als het gaat om het risico op arbeidsuitval omdat men tijdens het werk regelmatig kracht moet zetten.

Werken in een lawaaiige omgeving kan onomkeerbare gehoorschade en doofheid tot gevolg hebben. Wegwerkers die met lawaaiige apparaten zoals drilboren, schuurmachines en motorzagen werken, productiemedewerkers in lawaaiige fabriekshallen, maar ook orkestleden of badmeesters die uren achtereen worden blootgesteld aan schadelijke geluidsniveaus zijn bekende risicogroepen als het gaat om het werken in een lawaaiige omgeving.

Het regelmatig tijdens het werk geconfronteerd worden met trillingen kan rugklachten en bijvoorbeeld klachten aan ledematen veroorzaken. Werken op bijvoorbeeld landbouwvoertuigen of heftrucks die lichaamstrilling veroorzaken kan voor met name de onderrug erg belastend zijn en vormt daarmee een belangrijke risicofactor. Het

10. Ministerie van Sociale Zaken en Werkgelegenheid (2002), Arbobalans 2002, Den Haag. 
werken met kleinere trillende apparaten, zoals boren of zagen veroorzaakt niet zozeer problemen aan de rug, als wel problemen met de bloedstoevoer aan hand of arm. Bekend is het witte-vingersyndroom: een verstoring van de bloedtoevoer en/of afsterving van zenuwen in de vinger.

Figuur 2.1 laat zien dat de totale fysieke belasting in de bouw het hoogst is. Dat is overigens al jaren zo. De metalektro en landbouw en visserij volgen, net als in voorgaande jaren, op enige afstand. De afstand tussen deze sectoren is zelfs wat gegroeid, omdat de fysieke belasting voor de werkenden in de bouw de laatste paar jaren wat is toegenomen, terwijl de metalektro er in geslaagd is de fysieke belasting die het werk met zich meebrengt iets te verminderen.

In de bouwsector hebben werkenden meer dan in andere sectoren te maken met trilling. Ook moeten zij vaker kracht zetten. Wat dat laatste betreft is er echter maar een klein verschil met de landbouwsector. In de bouw moet $45 \%$ van de werknemers regelmatig kracht zetten, in de landbouwsector $43 \%$. Werken in een lawaaiige omgeving komt het meest voor in de voedingssector, gevolgd door de metalektro. lets meer dan een kwart van de werkenden in deze beide bedrijfssectoren werkt regelmatig onder lawaaiige omstandigheden. Opvallend is de toename van de totale fysieke belasting in de sector voeding. Hierbij gaat het met name om een aanzienlijke toename van het percentage werkenden dat regelmatig kracht moet zetten.

Figuur 2.1

Regelmatig fysieke belasting naar bedrijfssector, indexcijfer 2000 en gemiddelde 2001/2002

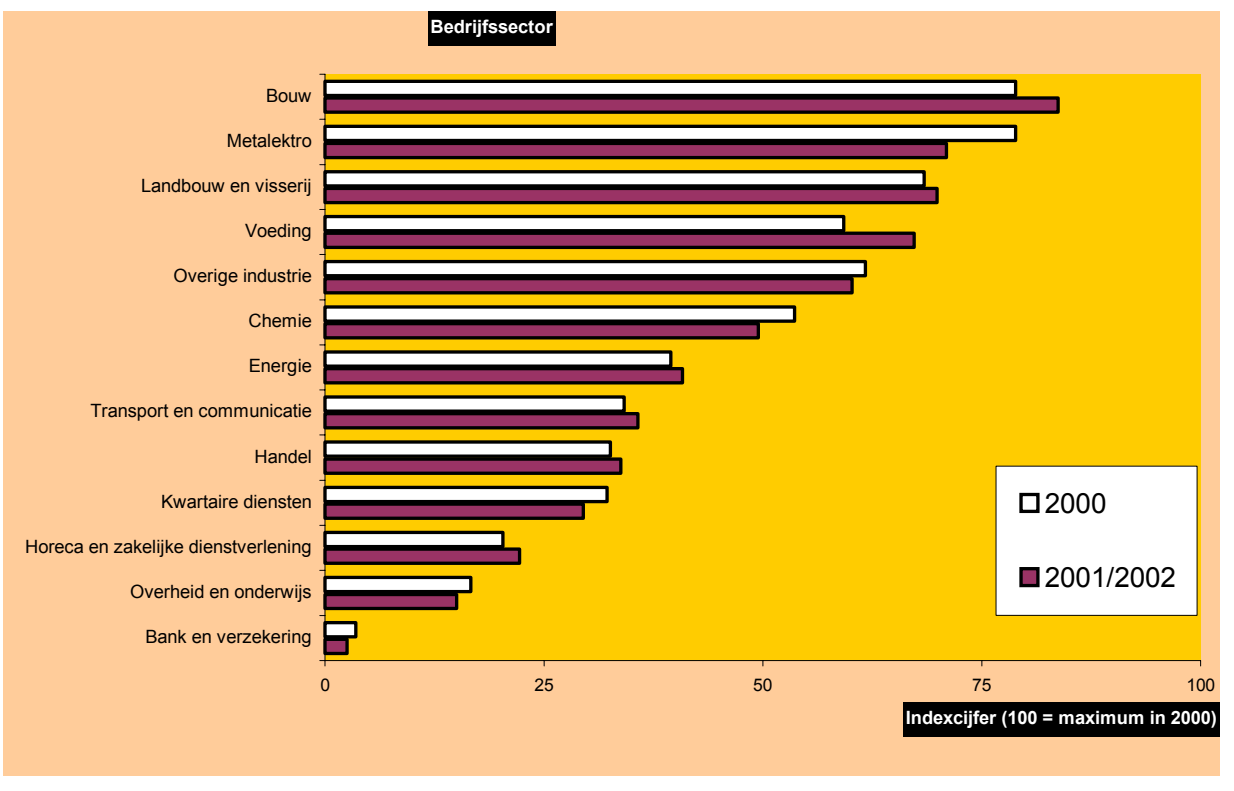

Bron: EBB (CBS)

Ten opzichte van andere lidstaten van de Europese Unie doet Nederland het voor wat betreft de fysieke belasting overigens opvallend goed. Waar voor de gehele EU 
de belasting als gevolg van lawaai en/ of trilling licht toeneemt, neemt deze voor Nederland juist wat af. ${ }^{11}$

\section{Fysieke belasting: Risicoberoepen}

Het zijn vooral de werkenden in de technische beroepen die worden geconfronteerd met een hoge fysieke belasting. Dat geldt voor vrijwel alle bedrijfssectoren, maar zeker in de bouw, de metalektro, de voedingsindustrie en de landbouwsector. In de bouw, maar ook in de metalektro, vormen de bouwvakkers de belangrijkste risicogroep als het gaat om de fysieke belasting tijdens het werk. Andere risicogroepen in de bouwsector zijn de weg- en waterbouwkundige arbeiders. In de metalektro zijn behalve de bouwvakkers ook de bankwerkers, de lassers en de metaalarbeiders de grootste risicogroepen.

In de sector voeding, de sector met de grootste toename van de fysieke belasting (vooral kracht zetten), zijn het vooral de monteurs en de chauffeurs die het fysiek zwaar hebben. Vooral lawaai en kracht zetten zorgen voor de belasting.

Ook verpleeghulpen en ziekenverzorgenden in de kwartaire sector (die voor een groot deel betrekking heeft op de gezondheidszorg) behoren tot de grootste risicoberoepen voor wat betreft de fysieke belasting tijdens het werk. Echter alleen voor wat betreft kracht zetten. Lawaai en trilling zorgen noch voor de verpleeghulpen, noch voor de ziekenverzorgenden voor extra belasting. De laatste jaren is de totale fysieke belasting voor de verpleeghulpen en ziekenverzorgenden ongeveer gelijk gebleven.

\section{Fysieke belasting: Risico-opleidingen}

Vooral de lager opgeleiden hebben te maken met een hoge fysieke belasting gedurende het werk. Zowel in de bouwsector als de metalektro gaat het daarbij vooral om werkenden met een VMBO opleiding mechanische techniek. In de metalektro worden daarnaast ook MBO'ers met een opleiding werktuigbouw en mechanische techniek fysiek zwaar belast. In de bouw vormen de VMBO'ers bouwtechniek ook een belangrijke risicogroep.

Opmerkelijk is dat in de landbouwsector de middelbaar opgeleiden fysiek zwaarder worden belast dan de werkenden zonder opleiding of een opleiding op VMBO niveau. Vooral de werkenden met een opleiding MBO landbouw en veeteelt of MBO milieu en groene ruimte hebben in hun werk met een erg hoge fysieke belasting te maken. Ook in de voedingssector zijn het vooral de werkenden met MBO natuur en techniek die met zware fysieke belasting worden geconfronteerd. Hoewel deze groep werkenden niet op alledrie de belastingsfactoren erg hoog scoort, baart het sterk stijgende percentage werkenden met deze opleidingsachtergrond dat regelmatig met trilling te maken heeft of kracht moet zetten wel enige zorg.

11. P. Paoli (2001), Third Survey on the Work Environment 2000. European Foundation for the improvement of Living and working conditions. Dublin: Loughlinstown House. 
De fysieke belasting van 'ongeschoolde' werkenden met alleen basisonderwijs neemt de laatste jaren over het algemeen wat af, zowel in de bouwsector als in de metalektro. Alleen in de voedingssector neemt de belasting voor wat betreft kracht zetten sterk toe.

Voor werkenden met een VMBO opleiding in een technische richting neemt de belasting in de bouwsector en de metalektro flink toe. In de voedingsindustrie neemt de belasting voor deze groep over het algemeen juist wat af. Voor de MBO'ers met een technische opleiding neemt de belasting vooral in de voedingssector echter sterk toe. In de metalektro is er een lichte toename en in de landbouw en de bouw is de belasting voor deze groep werkenden ongeveer gelijk gebleven.

In de kwartaire dienstensector vormt het regelmatig kracht moeten zetten een risicofactor voor werkenden met een $\mathrm{MBO}$ opleiding in de richting dienstverlening en gezondheidszorg. De helft van de werkenden met deze opleidingsachtergrond moet regelmatig kracht zetten. Het gaat hierbij vooral om werkenden met een opleiding MBO verzorging, $\mathrm{MBO}$ verpleging of $\mathrm{MBO}$ horeca. Opvallend is ook het grote aandeel van de werkenden met een $\mathrm{HBO}$ opleiding radiologie dat regelmatig kracht moet zetten: $50 \%$. Voor deze groep is overigens wel sprake van een sterk dalende trend.

De nog steeds hoge risico's op verlies van werk vanwege fysiek belastende arbeidsomstandigheden van technisch opgeleiden en verpleegkundigen betekenen niet alleen dat de kosten van de vroegtijdige arbeidsuitval voor deze groepen werkenden hoog zijn. Het zijn opmerkelijk genoeg ook de opleidingscategorieën waarvoor de knelpunten op de arbeidsmarkt op MBO niveau structureel het grootst zijn. Een toenemende aandacht voor een adequaat ARBO beleid zou derhalve een belangrijke bijdrage kunnen leveren aan het verminderen van de personeelstekorten op deze segmenten van de arbeidsmarkt. Hetzelfde geldt voor een adequaat scholingsbeleid. Scholingsbeleid is adequaat wanneer het allereerst tot resultaat heeft dat werkenden zich langer in hun functie kunnen handhaven doordat zij leren om goed om te gaan met belastende arbeidsomstandigheden. Daarnaast levert adequaat scholingsbeleid ook een verbetering van het doorstroomperspectief naar andere functies op. Niet alleen binnen de eigen organisatie, zoals tot nu toe nog té gebruikelijk is ${ }^{12}$, maar ook daarbuiten. Adequaat scholings- en ARBO beleid zou ook de aantrekkingskracht van de technische en verpleegkundige opleidingen kunnen vergroten, zodat het beeld wordt weggenomen dat het voor de werkenden op deze segmenten van de arbeidsmarkt vanwege de fysiek belastende arbeidsomstandigheden erg moeilijk is om hun employability op de langere termijn op peil te houden.

\section{Psychische belasting; tijdsdruk}

De psychische belasting waarmee werkenden in de verschillende bedrijfssectoren worden geconfronteerd wordt bepaald aan de hand van het percentage werkenden dat regelmatig onder hoge tijdsdruk werkt. Het werken onder hoge tijdsdruk verhoogt

12. J.M.A.F. Sanders en A. de Grip (2004), Training, task flexibility and low-skilled workers' employability, International Journal of Manpower, 25, pp. 73-89. 
de kans op stress en burnout en daarmee de kans op verlies van werk. ${ }^{13} \mathrm{Al}$ sinds 1990 vormen stress en burnout de oorzaak van ongeveer $30 \%$ van de afkeuringen in het kader van de WAO. ${ }^{14}$

De tijdsdruk is in vrijwel alle sectoren van de economie sinds 2000 wat afgenomen, zo blijkt uit figuur 2.2. Een uitzondering is de voedingsindustrie, waar sprake is van een kleine toename van het percentage werkenden dat regelmatig onder hoge tijdsdruk werkt.

De tijdsdruk is nog altijd het hoogst in de transportsector en de kwartaire sector. Meer dan $30 \%$ van de werkenden in deze sectoren werkt regelmatig onder hoge tijdsdruk. In het bank en verzekeringswezen is de tijdsdruk gelijk gebleven. Omdat in de horeca en zakelijke dienstverlening en in de sector overheid en onderwijs de tijdsdruk de laatste paar jaren wat is afgenomen is het bank- en verzekeringswezen nu voor wat betreft het risico op verlies van werk als gevolg van het regelmatig moeten werken onder hoge tijdsdruk, de derde 'risico'-sector.

\section{Psychische belasting: Risicoberoepen}

In de transportsector hebben vooral vliegers, scheepskapiteins en leidinggevenden in het transport (vlieg- en vaarschema's), productieplanners en managers te maken met een hoge tijdsdruk. Ongeveer de helft van de werkenden in deze beroepsgroep geeft aan regelmatig met een hoge tijdsdruk te worden geconfronteerd.

In de kwartaire sector hebben vooral journalisten en kunstenaars regelmatig te maken met een hoge tijdsdruk. Respectievelijk 70 - en $57 \%$. In dezelfde sector werken echter ook managers, artsen, afdelingshoofden van zorginstellingen, ziekenverzorgenden, hoofden sociaal-cultureel werk en p\&o en onderwijskundigen/ pedagogen vaak onder hoge tijdsdruk. De situatie waarin de ziekenverzorgenden verkeren vraagt echter nog extra aandacht. Zij worden niet alleen regelmatig geconfronteerd met een hoge tijdsdruk, maar zij moeten bovendien, zo bleek eerder, zeer regelmatig kracht zetten.

In het bank- en verzekeringswezen vormen vooral de juristen een belangrijke risicogroep voor wat betreft het moeten werken onder hoge tijdsdruk: $62 \%$ van de juristen in het bank- en verzekeringswezen heeft regelmatig met een hoge tijdsdruk te maken, al neemt de tijdsdruk de laatste jaren wel wat af. Juristen die in de zakelijke dienstverlening werkzaam zijn vormen eveneens een belangrijke risicogroep.

13. J.J.L. Klink, R.W.B. Blonk, A.H. Schene en F.J.H. van Dijk (2001), Short-term outcome of a job-stress reducing program conducted by occupational physicians, American Journal of Public Health.

J. de Jonge, I.L.D. Houtman en P.M. Bongers (2000), Linear and nonlinear relations between psychosocial job characteristics, subjective outcomes, and sickness absence: baseline results from SMASH, Journal of occupational health psychology; p. 5: pp. 256-268.

14. W.B. Schaufeli (2000), Meten van werkstress, overzicht van methoden, moeilijkheden en mogelijkheden, Houten: Bohn/ Stafleu/ van Loghum. 
Figuur 2.2

Regelmatig werken onder hoge tijdsdruk naar bedrijfssector, 2000 en 2001/2002 Bron: EBB (CBS)

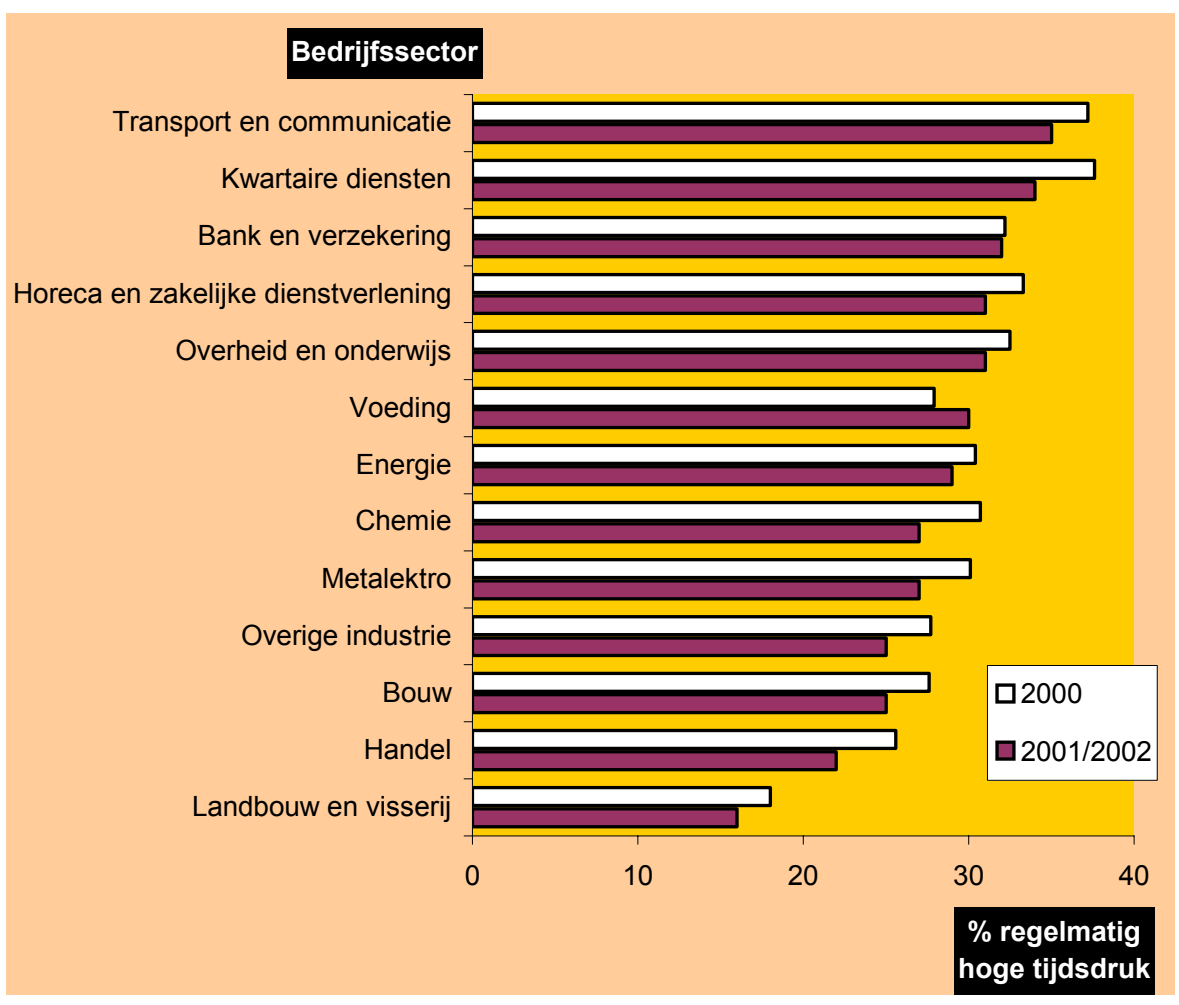

Ook managers vormen een belangrijke risicogroep. Dat geldt in eerste instantie voor de managers in de metalektro, maar bijvoorbeeld ook voor managers in de sectoren overheid en onderwijs, kwartaire diensten en transport en communicatie. Zo'n $60 \%$ van de managers in deze sectoren werkt regelmatig onder hoge tijdsdruk. Hetzelfde geldt ten slotte voor de organisatiedeskundigen in de zakelijke dienstverlening, van wie $58 \%$ regelmatig met hoge tijdsdruk kampt.

\section{Psychische belasting: Risico-opleidingen}

Over het algemeen zijn het met name de hoger opgeleiden die vaak te maken hebben met een hoge tijdsdruk tijdens hun werk. Dat geldt echter opmerkelijk genoeg niet voor de transportsector. In deze sector vormen juist de werkenden met een lagere of middelbare opleiding de grootste risicogroepen. Meer specifiek gaat het om de werkenden met een opleiding MBO vervoer en logistiek, MBO openbare orde en veiligheid of VMBO mechanisch techniek. Zo'n $45 \%$ van de werkenden in de transportsector met deze opleidingsachtergronden werkt regelmatig onder hoge tijdsdruk.

In de kwartaire sector zijn het wel de werkenden met een hogere opleiding die het meest onder hoge tijdsdruk werken. Van de werkenden met een medische opleiding 
op universitair niveau werkt bijvoorbeeld zo'n 56\% regelmatig onder hoge tijdsdruk. De werkenden met $\mathrm{HBO}$ verpleegkunde en $\mathrm{HBO}$ radiologie volgen op kleine afstand. Voor werkenden met $\mathrm{HBO}$ radiologie zorgt de combinatie van het werken onder hoge tijdsdruk met het veel kracht moeten zetten nog voor extra risico. Behalve de werkenden met een medische opleiding staan in de kwartaire dienstensector ook de werkenden met een opleiding HBO communicatie en journalistiek (de journalisten), $\mathrm{HBO}$ personeel en arbeid of HBO uitvoerende en beeldende kunsten (kunstenaars) onder erg hoge tijdsdruk.

In het bank- en verzekeringswezen staan vooral de werkenden met een WO opleiding rechten en bestuurskunde (juristen) onder hoge tijdsdruk. De tijdsdruk onder de werkenden met deze opleidingsachtergrond neemt de laatste paar jaren zelfs enigszins toe.

De tijdsdruk is het hoogst onder de werkenden met een opleiding accountancy en belastingen of rechten en bestuurskunde op WO niveau in de zakelijke dienstverlening. Ruim $60 \%$ van deze groep werkenden werkt regelmatig onder hoge tijdsdruk. Het gaat hierbij vooral om de al eerder genoemde (interim) managers, organisatiedeskundigen en juristen.

\section{Psychische belasting; sociale veiligheid}

Psychische belasting kan ook andere oorzaken hebben dan een hoge tijdsdruk. Werknemers kunnen zich eveneens belast voelen wanneer zij in hun 'sociale veiligheid' worden aangetast. Dit is bijvoorbeeld het geval wanneer werknemers tijdens hun werk geconfronteerd worden met intimidatie of bijvoorbeeld ongewenste seksuele aandacht. Het gaat daarbij niet alleen om werknemers die tijdens de uitvoering van het werk in contact staan met bijvoorbeeld klanten en patiënten. Weliswaar komt agressie en intimidatie het vaakst van de kant van de klant of patiënt, maar ook collega's en chefs of leidinggevenden kunnen het werknemers lastig maken optimaal te functioneren. In principe zijn er drie uitingsvormen van 'agressief gedrag' van klanten, collega's of chefs die voor extra psychische belasting kunnen zorgen:

- Ongewenste seksuele aandacht;

- Intimidatie (bedreigingen, chantage);

- Lichamelijk geweld (slaan, schoppen, vastgrijpen).

De redenen voor het uiten van agressief gedrag zijn verschillend. Meestal gaat het bij klanten en patiënten om het afreageren van frustraties. Bij collega's en chefs gaat het eerder om pesterijen of om pogingen iets van iemand gedaan te krijgen. In enkele gevallen spelen alcohol of verdovende middelen een rol.

In figuur 2.3 wordt een overzicht gegeven van de mate waarin de werkenden in de verschillende bedrijfssectoren risico's lopen op verlies van werk, als gevolg van het feit dat men tijdens het werk geconfronteerd wordt met agressief gedrag. Hierbij is gebruik gemaakt van twee samengestelde indicatoren met betrekking tot (1) het 
agressieve gedrag (ongewenst seksuele aandacht, intimidatie en lichamelijk geweld) van klanten of patiënten en (2) het agressieve gedrag van chefs of collega's.

Figuur 2.3

'Agressief gedrag' in bedrijfssectoren, 2002

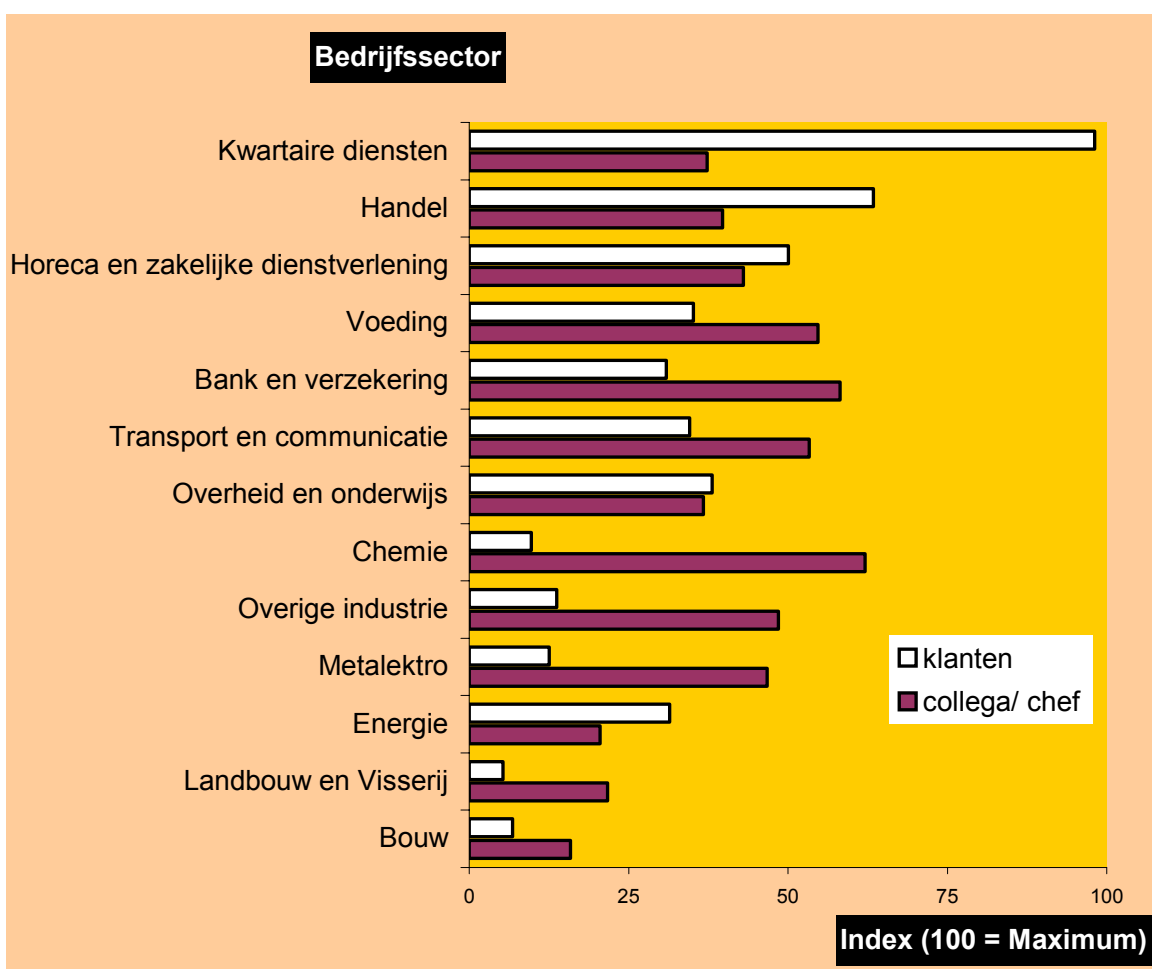

Bron: TAS (TNO)

Intimidatie door klanten of patiënten komt het meest voor. Circa $20 \%$ van de werknemers heeft hiermee wel eens te maken. Intimidatie door chef of collega's raakt 1 op de 8 werknemers. Ongewenste seksuele aandacht en lichamelijk geweld van zowel klanten of patiënten als chefs of collega's komt heel wat minder vaak voor, zij het dat nog altijd zo'n 6\% van de werknemers wel eens geconfronteerd wordt met ongewenste seksuele aandacht of lichamelijk geweld door klanten of patiënten. Ten slotte wordt $3 \%$ van de werknemers geconfronteerd met ongewenste seksuele aandacht van chef of collega's en heeft $1 \%$ wel eens te maken met lichamelijk geweld van de kant van de chef of naaste collega's.

Figuur 2.3 laat zien dat voor wat betreft het agressieve gedrag van klanten of patiënten de sector kwartaire diensten (w.o. de gezondheidszorg) eruit springt. De werkenden in de kwartaire diensten het vaakst geconfronteerd met zowel ongewenste seksuele aandacht, als intimidatie of lichamelijk geweld. Dat geldt voornamelijk voor de werkenden in (para)medische beroepen, zoals ziekenverzorgenden en verpleeghulpen. 
Op enige afstand van de werknemers in de kwartaire sector volgen de mensen die werkzaam zijn in de handel. Vooral intimidatie door klanten komt in deze sector verhoudingsgewijs veel voor. In de handel worden vooral de werkenden in beroepen als verkoper, winkelier of winkelbediende in hun sociale veiligheid aangetast. $40 \%$ van de werkenden in deze beroepsgroep heeft te maken met intimidatie door klanten.

Ook in de derde risicosector voor wat betreft het agressieve gedrag van klanten, de horeca, hebben vooral werkenden in de verzorgende en dienstverlenende beroepen relatief vaak te maken met ongewenste seksuele aandacht, intimidatie of zelfs lichamelijk geweld. Het gaat daarbij vooral om kelners (serveersters), buffetbedienden en koks. Opvallend is ten slotte vooral het hoge percentage leidinggevenden in de horeca dat met lichamelijk geweld van klanten wordt geconfronteerd. Hierbij gaat het waarschijnlijk om eigenaren of uitbaters van uitgaansgelegenheden.

Agressief gedrag van chefs of collega's zien we het meest in de chemie en het banken verzekeringswezen. Vooral ongewenste seksuele aandacht komt in deze beide sectoren wat vaker voor. In het bank- en verzekeringswezen gaat het vooral om verzekeringsagenten en andere tussenpersonen. In de chemie is er geen specifieke beroepsgroep als risicogroep aan te wijzen. Wel zien we dat in deze sector vooral de hoger opgeleiden wat meer met ongewenste seksuele aandacht van chef of collega's worden geconfronteerd. Intimidatie door chef of collega's komt het meest voor in de transportsector, de voedingssector, de chemie en de metalektro. Opvallend is dat het in de transportsector en de metalektro vooral de hoger opgeleiden zijn die met intimidatie door chef of collega's te maken hebben, terwijl in de sectoren voeding en chemie vooral de VMBO'ers met deze vorm van agressief gedrag te maken hebben.

Onderzoek bij Nederlandse gemeenten laat zien dat agressief gedrag van de kant van klanten vooral het plezier in het werk vermindert en het functioneren aantast, omdat werknemers naar aanleiding van voorvallen nadrukkelijker op hun hoede willen zijn voor agressief gedrag in de toekomst. Agressief gedrag van de kant van collega's en chefs komt weliswaar minder vaak voor, maar kan zeer ernstige gevolgen hebben voor werknemers. Pesten heeft bijvoorbeeld zeer ernstige gevolgen voor de gezondheid. Onderzoek naar de effecten van pesten op het werk heeft uitgewezen dat al na enkele dagen psychosomatische klachten optreden, zoals: maag- en darmklachten, hoofdpijn, slapeloosheid, transpiratie en gespannenheid. De gevolgen voor het functioneren van werknemers zijn voorspelbaar: verzuim en in het ergste geval zelfs arbeidsongeschiktheid. Uit het onderzoek bij de gemeenten bleek dat bij $22 \%$ van degenen die op hun werk werden gepest en bij $7 \%$ van de werkenden die geconfronteerd werden met seksuele intimidatie, dit leidde tot ziekteverzuim. Pesten op het werk leidt overigens voor hele afdelingen (dus niet alleen voor het slachtoffer) tot meer verzuim, meer verloop en een verminderde arbeidsvreugde. ${ }^{15}$ Agressief gedrag, pestgedrag en seksuele intimidatie van klanten of collega's leidt dus tot ziekteverzuim, instroom in de WAO en verloop van

15. L.K. Middelhoven en H.M.H.M. Driessen (2001), Geweld tegen werknemers in de (semi) openbare ruimte, Utrecht. 
personeel ${ }^{16}$ oftewel (gedeeltelijk) verlies van werk. Dat verlies van werk kan voorkomen worden door goede (team)trainingen die werknemers die in hun werk veel te maken hebben met agressie, pestgedrag of intimidatie voor de arbeidsmarkt weerbaarder maken, zodat zij langer behouden blijven voor de arbeidsmarkt.

\section{Beeldschermwerk}

Een van de steeds belangrijker wordende oorzaken van ziekteverzuim en arbeidsmarktuitstroom is RSI. Oorzaken van RSI zijn het langdurig werken in dezelfde houding en het regelmatig maken van dezelfde beweging. Het regelmatig verrichten van beeldschermwerk is de laatste jaren een belangrijke veroorzaker van RSI. Werknemers die beeldschermwerk verrichten zitten immers langdurig in dezelfde houding en maken vaak dezelfde bewegingen (muisklik, typewerk). Het regelmatig verrichten van beeldschermwerk op zichzelf hoeft echter niet schadelijk te zijn. Zolang werkenden voldoende rust kunnen nemen en zij voldoende afwisseling kunnen inbouwen door bijvoorbeeld even wat anders te doen wordt het risico op RSI aanzienlijk beperkt. Wanneer echter het regelmatig verrichten van beeldschermwerk wordt gecombineerd met een hoge tijdsdruk wordt het risico op vormen van RSI aanzienlijk verhoogd. De extra spierspanning die het werken onder tijdsdruk met zich meebrengt en het gebrek aan rustpauzes die door de hoge tijdsdruk worden overgeslagen maakt dat vormen van RSI zich sneller manifesteren. Om deze reden worden in deze paragraaf vooral de werkenden die én regelmatig beeldschermwerk verrichten én onder hoge tot zeer hoge tijdsdruk staan tot de risicogroepen gerekend voor wat betreft de kans op verlies van werk vanwege slijtage (technische competentieveroudering).

Uit figuur 2.4 blijkt dat in de sector bank en verzekering nog altijd verreweg het meeste beeldschermwerk wordt verricht: $90 \%$ van de werkenden in deze sector zit regelmatig achter een beeldscherm. Op enige afstand volgen de energiesector met iets minder dan $70 \%$ en de sectoren horeca en zakelijke dienstverlening en overheid en onderwijs, waar zo'n $60 \%$ van de werknemers regelmatig beeldschermwerk verricht. Vooral in het bank- en verzekeringswezen, waar naast het vele beeldschermwerk ook onder relatief hoge tijdsdruk wordt gewerkt ontstaat het risico op verlies van werk als gevolg van RSI. Werkenden in de sectoren horeca en zakelijke dienstverlening en overheid en onderwijs lopen, zij het in wat mindere mate, hetzelfde risico.

In zowel de transportsector als de landbouwsector is er sprake van een flinke toename van het percentage werkenden dat regelmatig beeldschermwerk verricht. Vooral voor de transportsector, de sector waar naar verhouding de meeste werkenden regelmatig onder hoge tijdsdruk werken (zie figuur 2.2), duidt dit op een toenemend risico op arbeidsuitval als gevolg van RSI.

16. J. Zoethout en M. Sloep (2000), Evaluatie Arbowet over seksuele intimidatie, agressie en geweld en pesten op het werk, Den Haag: Elsevier. 
Figuur 2.4

Regelmatig beeldschermwerk in bedrijfssectoren, 2000 en 2001/2002

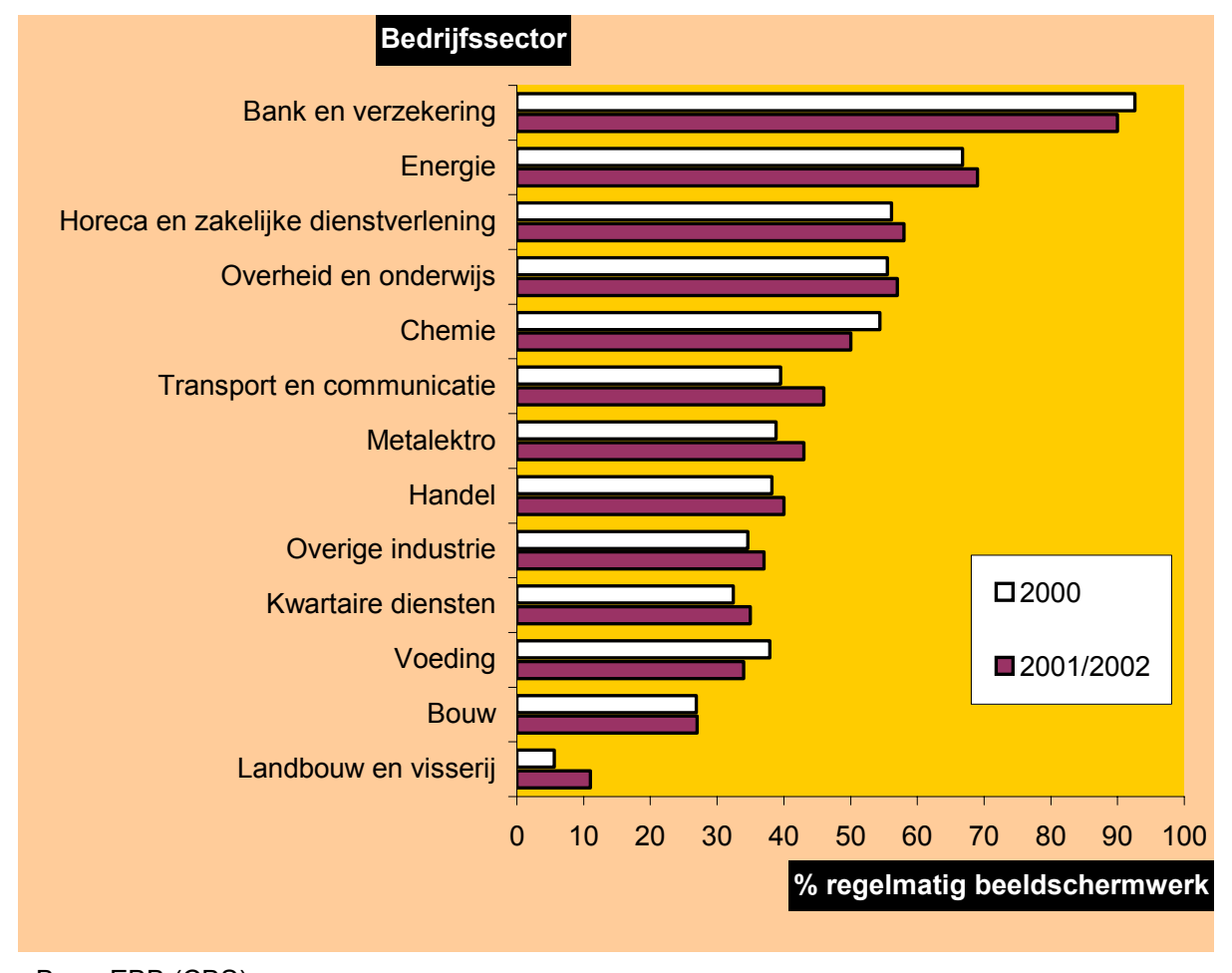

Bron: EBB (CBS)

\section{Beeldschermwerk: Risicoberoepen}

Het spreekt voor zich dat vooral werkenden in de informaticaberoepen regelmatig beeldschermwerk verrichten. Van de programmeurs en systeemanalisten bevindt zich zo'n 95\% regelmatig achter de computer. In de sectoren overige industrie en overheid en onderwijs geldt dat zelfs voor praktisch alle programmeurs en systeemanalisten. Alleen bij de werkenden in informaticaberoepen in de handel -en dan met name de systeemanalisten- is er echter sprake van de risicovolle combinatie van regelmatig beeldschermwerk en een erg hoge tijdsdruk.

Binnen het bank- en verzekeringswezen, de sector waar het meeste beeldschermwerk wordt verricht, zit vrijwel iedereen die in een economisch administratief of informaticaberoep werkzaam is regelmatig achter de computer. Van de verzekeringsagenten en juristen verricht zelfs $100 \%$ regelmatig beeldschermwerk. Vooral juristen vormen op dit punt een risicogroep, omdat zij ook regelmatig onder hoge tijdsdruk werken.

In de energiesector werken vooral de boekhouders en secretaresses regelmatig achter de computer: $97 \%$ van hen verricht regelmatig beeldschermwerk. Tijdsdruk speelt voor hen echter een minder belangrijke rol. 
In de zakelijke dienstverlening zijn het, vanwege de combinatie van het regelmatig beeldschermwerk verrichten en het werken onder hoge tijdsdruk, met name de accountants die een verhoogd risico lopen op arbeidsuitval vanwege RSI. Naast voor de hand liggende beroepsgroepen als de programmeurs en de (technische) systeemanalisten verrichten ook elektrotechnici, hoofden van technische diensten, assistent accountants, boekhouders en secretaresses en medewerkers sociaal-cultureel werk en p\&o veel beeldschermwerk. Bij al deze groepen is er echter geen sprake van een verhoogd risico vanwege de tijdsdruk waaronder men moet werken.

In de sector overheid en onderwijs verrichten vooral de bibliothecarissen veel beeldschermwerk. Vrijwel alle werkenden in deze beroepsgroep zitten regelmatig achter de computer. Ook hier is er echter geen sprake van een hoog risico op RSI, omdat de tijdsdruk waaronder men moet werken niet al te hoog is.

Twee andere beroepsgroepen die te maken hebben met zowel een hoge tijdsdruk als regelmatig beeldschermwerk zijn de journalisten in de grafische industrie en de productieplanners in de transportsector. Ook de werkenden in deze beroepsgroepen vormen derhalve belangrijke risicogroepen voor wat betreft de arbeidsuitval vanwege RSI.

\section{Beeldschermwerk: Risico-opleidingen}

In het bank- en verzekeringswezen verrichten vooral de werkenden met een universitaire opleiding in de wiskunde en natuurwetenschappen, HBO accountancy en bedrijfseconomie of MBO automatisering veel beeldschermwerk. De tijdsdruk vormt voor deze drie groepen echter geen risicoverhogende factor. Dat is anders voor de werkenden met een opleiding HBO informatica. Zij zitten niet alleen vrijwel allemaal regelmatig achter de computer, maar zij worden daarbij ook nog geconfronteerd met een hoge tijdsdruk. Die tijdsdruk is overigens de laatste jaren wel wat aan het afnemen.

In de energiesector zitten de werkenden met een middelbare of hogere economische opleiding het meest achter de computer. Men werkt daarbij echter niet vaak onder een hoge tijdsdruk. In de sector horeca en zakelijke dienstverlening komt de combinatie van een hoge tijdsdruk en veel computerwerk eveneens niet voor. Wel verrichten werkenden met een $\mathrm{HBO}$ of WO opleiding in deze sector nagenoeg allemaal regelmatig beeldschermwerk, net als de werkenden met een opleiding MBO secretariaat.

\subsection{Technologische en organisatorische ontwikkelingen}

Technologische en organisatorische ontwikkelingen hebben, vooral in combinatie met elkaar, een grote invloed op de inhoud van het werk. In vrijwel elke beroepsgroep heeft met name de automatisering de afgelopen 20 jaar het werk en de organisatie ervan ingrijpend veranderd. Hierdoor is de werkgelegenheid in verschillende beroepsgroepen sterk afgenomen (datatypisten), terwijl andere 
beroepsgroepen (automatiseringsdeskundigen, programmeurs, callcenter-agents) enorm zijn gegroeid.

Nieuwe machines, nieuwe computersystemen, nieuwe productielijnen en nieuwe vormen van communicatie vragen om aanpassingen in de manier van werken, veranderingen in de organisatie van het werk én om een actualisering van kennis en vaardigheden. Men spreekt in dit verband wel van de halfwaardetijd van kennis. Dat is de periode na het afronden van de initiële vakopleiding, waarin iemand door veranderingen in de inhoud van het werk nog slechts half zo competent is om zijn of haar vak uit te oefenen als direct na het behalen van het vakdiploma. ${ }^{17}$

Wanneer er niet voldoende in scholing wordt geïnvesteerd om aan de nieuwe kennisbehoefte te voldoen, lopen bedrijven en instellingen het risico de concurrentieslag niet meer aan te kunnen. Werknemers van wie de competenties als gevolg van te gebrekkige investering niet meer voldoende waarde hebben voor de organisatie krijgen op den duur te maken met een verhoogd risico op verlies van werk. Hun competenties zijn dan immers 'verouderd' en verliezen geleidelijk hun waarde voor de arbeidsmarkt.

Technologische en organisatorische vernieuwingen spelen niet voor elke sector of elke beroepsgroep een even grote rol. Zo heeft onderzoek van den Boer en Hövels aangetoond dat de invloed van technologische ontwikkelingen groter is in organisaties waar veel verpleegkundigen of multimedia vormgevers werken. ${ }^{18}$ Vooral wanneer sectoren in een zeer open en dynamische internationale afzetmarkt opereren, is het vaak van levensbelang snel en adequaat in te springen op nieuwe technologische ontwikkelingen.

Om per bedrijfssector een beeld te krijgen van de mate waarin technologische en organisatorische ontwikkelingen een rol spelen, wordt in dit rapport gebruik gemaakt van een indexcijfer waarin een achttal belangrijke technologische en organisatorische ontwikkelingen gecombineerd worden:

- Ingrijpende vernieuwingen in het product- of dienstenaanbod;

- Marginale vernieuwingen in het product- of dienstenaanbod;

- Procesvernieuwingen in bedrijven;

- Het bereik van deze procesvernieuwingen;

- Mate van informatisering (gemiddelde 2001/2002);

- Mate van automatisering (gemiddelde 2000/2001);

- Interne reorganisaties;

- Veranderingen van de positie binnen een groter geheel.

17. Zie A. de Grip (2001), Dynamiek op de arbeidsmarkt en de employability van werkenden, Tijdschrift voor Arbeidsvraagstukken, 17, pp. 213-221.

18. P. den Boer en B. Hövels (2003), Werken en leren in arbeidsorganisaties, OSA Publicatie A187, Tilburg. 
Veranderingen in het product- of dienstenpakket dat een instelling of bedrijf aanbiedt kunnen fors ingrijpen in de functie en het takenpakket van werkenden. Wanneer het gaat om kleine veranderingen is een kort bijscholingstraject in de meeste gevallen voldoende om werknemers van benodigde nieuwe kennis te voorzien over de veranderde producten of diensten. Gaat het om ingrijpende veranderingen, zoals het uit het pakket nemen van een product of dienst, dan heeft dat in de meeste gevallen ook grotere gevolgen voor de kennisbehoefte van bedrijf of instelling maar ook voor de waarde van de competenties van de werkenden die zich met de productie van het desbetreffende product bezighielden. Hun specifieke productkennis is dan immers verouderd.

Bij procesvernieuwingen gaat het om vernieuwing van het productie- of dienstverleningsproces binnen een bedrijf of instelling, bijvoorbeeld gericht op het efficiënter maken van productieprocessen, het verminderen van milieuschade of het verbeteren van de productkwaliteit. Voorbeelden van procesvernieuwingen zijn het opzetten van communicatienetwerken, kennissystemen of logistieke systemen en het in gebruik nemen van Computer Aided Design/ Manufacturing systemen (CAD/CAM). Dergelijke, vaak ingrijpende, vernieuwingen zijn onlosmakelijk verbonden met veranderingen in het werk van groepen werknemers. Omdat procesvernieuwingen betrekking kúnnen hebben op alle werknemers in een organisatie, maar ook beperkt kunnen zijn tot een klein percentage van de werknemers, is het van belang om ook het bereik van de procesvernieuwingen te bezien bij het bepalen van de impact van procesvernieuwingen in een bepaalde bedrijfssector.

Technologische ontwikkelingen worden meestal gemeten door te kijken naar de ontwikkelingen op ICT gebied. Het merendeel van de technologische ontwikkelingen is dan ook sterk gerelateerd aan de opkomst en het explosief gestegen gebruik van de (personal) computer, computergestuurde technieken en informatie- en communicatietechnologie. De automatisering van productieprocessen heeft er in het verleden voor gezorgd dat hele beroepsgroepen verdwenen. Nog altijd zorgt de automatisering van vooral eenvoudige, maar steeds vaker ook complexe, handelingen ervoor dat werknemers worden geconfronteerd met een verhoogd risico op verlies van werk als gevolg van competentieveroudering.

De reorganisatie van primaire productieprocessen en/of ondersteunende processen gaat vrijwel altijd gepaard met veranderingen in het werk dat mensen doen. Dat kunnen kleine veranderingen zijn, die met korte bijscholingstrajecten op te vangen zijn, maar het kan ook gaan om meer ingrijpende veranderingen, zoals een herplaatsing of zelfs gedwongen ontslag, waardoor omscholing of substantiële bijscholing meestal noodzakelijk is om weer elders aan de slag te kunnen komen. Van de reorganisaties die in de periode 1998-2000 plaatsvonden ging maar liefst tweederde gepaard met herplaatsing van personeel. Meer dan een kwart van de reorganisaties ging gepaard met inkrimping van het personeelsbestand, terwijl bij 1 op de 10 reorganisaties zelfs sprake was van gedwongen ontslagen. Dat naar aanleiding van de reorganisaties de inhoud van functies en takenpakketten van 
werknemers verandert blijkt wel uit het feit dat er in ruim $60 \%$ van de bedrijven waar tussen 1998 en 2000 werd gereorganiseerd extra om- en bijscholing plaatsvond. ${ }^{19}$

Herstructureringen, fusies en overnames kunnen ook ingrijpende gevolgen hebben. In ruim $60 \%$ van de bedrijven die hiermee te maken hebben, is herplaatsing van personeel een van de gevolgen. Bij een kwart van de bedrijven verdwijnen arbeidsplaatsen als gevolg van de herstructurering en in meer dan de helft van de bedrijven waar werd geherstructureerd leidt dit tot meer om- en bijscholing.

Figuur 2.5

Technologische en organisatorische vernieuwingen ${ }^{20}$ per bedrijfssector, 1999-2001

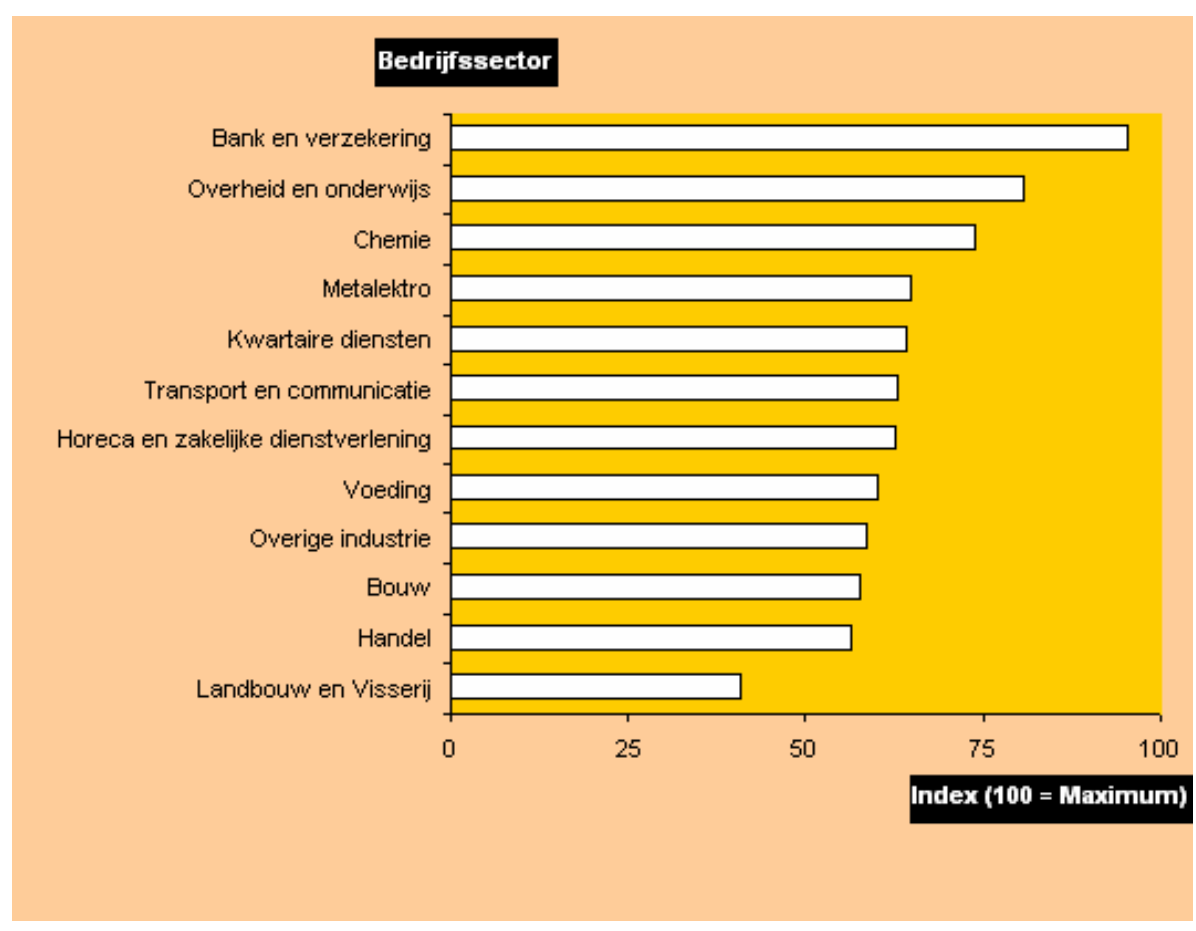

Bron: Arbeidsvraagsurvey (OSA), Automatiseringsstatistieken/ Statline (CBS), EBB (CBS)

Uit figuur 2.5 blijkt dat het bank- en verzekeringswezen de sector is waar de meeste technologische en organisatorische ontwikkelingen plaatsvinden. In meer dan de helft van de bedrijven in deze sector werden er zelfs ingrijpende veranderingen in de dienstverlening doorgevoerd. In andere sectoren is er bij ruim eenderde van de bedrijven sprake van ingrijpende veranderingen in de productie of dienstverlening. Ook vinden er in het bank- en verzekeringswezen meer fusies, overnames én interne reorganisaties plaats dan in welke sector dan ook. Bovendien is de informatiseringsgraad in deze sector verreweg het hoogst en wordt het werk van maar liefst $85 \%$ van

19. Dit blijkt na analyse van data in het OSA Arbeidsvraagpanel 2001.

20. Het gaat hierbij om een ongewogen indexcijfer, waarbij voor elk van de acht onderliggende indicatoren de hoogstscorende sector op 100 is gesteld en de totaalscore vervolgens is gemiddeld. 
de werknemers in het bank- en verzekeringswezen direct beïnvloed door de doorgevoerde procesvernieuwingen. Daarmee is het bereik van de procesvernieuwingen in het bank- en verzekeringswezen heel wat groter dan in alle andere sectoren, waar het werk van slechts $15-$ tot $45 \%$ van het personeel direct door vernieuwingen in het productieproces wordt beïnvloed. Vooral de informatieverspreiding en communicatie via netwerken krijgen in het bank- en verzekeringswezen veel aandacht.

In de chemie is er vaak sprake van automatisering en kleine veranderingen in het producten/dienstenaanbod. Bijna $60 \%$ van de bedrijven in deze sector heeft kleinere veranderingen in het productaanbod doorgevoerd en in $94 \%$ van de bedrijven is er sprake van een voortschrijdende automatisering. Omdat er in de chemie echter weinig organisatorische veranderingen plaatsvinden behoort deze sector niet tot de belangrijkste risicosectoren.

De sector overheid en onderwijs onderscheidt zich door een hoge mate van informatisering, zij het dat deze nog ruimschoots onder die van het bank- en verzekeringswezen ligt. Wel is in de sector overheid en onderwijs het percentage instellingen dat procesvernieuwingen doorvoert met bijna $54 \%$ het hoogst van alle sectoren. Het is echter belangrijk te constateren dat maar $43 \%$ van de werknemers in het dagelijkse werk direct met die procesvernieuwingen te maken heeft. De vernieuwingen in de sector overheid en onderwijs zijn vooral gericht op planmatiger werken, kwaliteitszorg en veiligheid en informatieverstrekking en communicatie via netwerken (internet/intranet). Ook is er vaker sprake van ingrijpende veranderingen in het dienstenpakket, waardoor de organisatie van het werk en het takenpakket van de werkenden in de sector eveneens aan veranderingen onderhevig is. Ten slotte vinden er in de sector overheid en onderwijs meer reorganisaties plaats dan in andere sectoren.

In de bouwsector en de landbouw ligt de frequentie van technologische en organisatorische ontwikkelingen op een lager niveau dan in de andere bedrijfssectoren. Alleen kleinere productveranderingen komen in de landbouwsector vrij regelmatig terug. Ingrijpende veranderingen in het productaanbod en interne reorganisaties vinden in niet meer dan 1 op de 7 bedrijven plaats. In de bouw voert ruim $20 \%$ van de bedrijven ingrijpende veranderingen of een reorganisatie door.

\subsection{Ontwikkelingen in de structuur van de werkgelegenheid}

De laatste paar jaar gaat het duidelijk minder goed met de Nederlandse economie. De economische groei ligt op een zeer laag niveau en onlosmakelijk daarmee verbonden krimpt ook de werkgelegenheid. De werkloosheid is dan ook in twee jaar tijd gestegen van $3,4 \%$ naar $5,8 \%$ van de beroepsbevolking ${ }^{21}$ en voor de nabije toekomst wordt een verdere stijging verwacht. Volgens het Centraal Planbureau ${ }^{22}$ zal

21. CBS (2003), Statline.

22. CPB (2003), Macro Economische Verkenningen 2004, Den Haag. 
als gevolg van de beperkte economische groei de werkgelegenheid in 2003 met $0,75 \%$ krimpen en in 2004 met $0,5 \%$. Daarna zal de werkgelegenheidsgroei zich naar verwachting weer gaan herstellen. Voor de periode tot 2008 wordt daardoor gemiddeld jaarlijks een lichte groei verwacht. De krimp voor het komende jaar en de groei voor de jaren daarna zal echter niet in alle arbeidsmarktsegmenten even goed merkbaar zijn. Voor de overheidssector is bijvoorbeeld nog steeds sprake van een lichte groei van de werkgelegenheid, net als in de zorgsector. In de metalektro en de overige industriesectoren is er echter op dit moment duidelijk sprake van een krimpende werkgelegenheid. Deze ontwikkelingen wijzen overigens ook op een voortgaande verschuiving van de werkgelegenheid van de industriesectoren naar de dienstensectoren.

Ontwikkelingen in de structuur van de werkgelegenheid leiden er toe dat werkenden worden gedwongen om van beroep of sector te veranderen. De voortgaande verschuiving van een industriële samenleving naar een diensteneconomie c.q. kenniseconomie dragen hier zeker aan bij. Deze (gedwongen) mobiliteit leiden er meestal toe dat het menselijk kapitaal van werkenden verloren gaat of in ieder geval een deel van haar waarde voor de arbeidsmarkt verliest. Dit is een vorm van wat in hoofdstuk 1 werd aangeduid als competentieveroudering vanwege verschuivingen in de werkgelegenheid.

In tabel 2.1 wordt een overzicht gegeven van de ontwikkelingen in de werkgelegenheid in de verschillende bedrijfssectoren. In de periode 1998-2002 was er sprake van een gemiddelde jaarlijkse groei van de werkgelegenheid van $2,2 \%$. Voor de komende jaren wordt echter verwacht dat de werkgelegenheidsgroei op een veel lager niveau zal liggen.

De voortschrijdende verschuiving van de werkgelegenheid van de industrie naar de dienstensector is in de tabel goed zichtbaar. Terwijl in de agrarische sector en enkele industriële sectoren de afgelopen jaren sprake is geweest van een voortgaande werkgelegenheidskrimp, is de werkgelegenheid flink toegenomen in dienstensectoren als het bank- en verzekeringswezen, de horeca en zakelijke dienstverlening, overheid en onderwijs en de kwartaire diensten. In de horeca en zakelijke dienstverlening steeg de werkgelegenheid in de jaren 1998-2002 jaarlijks zelfs met $5 \%$.

De sector landbouw en visserij valt op door de forse krimp van de werkgelegenheid in de afgelopen jaren en de verwachting dat deze daling van de werkgelegenheid zich de komende jaren in ongeveer hetzelfde tempo zal voortzetten. Hoewel een deel van de werkenden in de agrarische sector die hun werk zullen verliezen met (vervroegd) pensioen zal gaan, zal ook een belangrijk deel op zoek moeten naar ander werk in een andere sector. Ook voor de metalektro, de chemie, de overige industrie en de transport en communicatiesector wordt een jaarlijkse werkgelegenheidskrimp verwacht van $1 \%$ of meer. Door deze werkgelegenheidskrimp lopen de werkenden in deze sectoren de komende jaren een relatief groot risico op competentieveroudering. 
Tabel 2.1

Ontwikkeling van het aantal werkenden per bedrijfssector 1998-2002 en de verwachte werkgelegenheidsontwikkelingen voor 2003-2008, gemiddelde jaarlijkse percentages

\begin{tabular}{lccc}
\hline Bedrijfssector & $\begin{array}{c}\text { Aantal werkenden } \\
\text { gemiddelde } \\
2001-2002\end{array}$ & $\begin{array}{c}1998-2002 \\
\%\end{array}$ & $\begin{array}{c}2003-2008 \\
\%\end{array}$ \\
& & & \\
\hline Landbouw en visserij & 194.000 & $-2,5$ & $-2,6$ \\
Voeding & 148.500 & $-2,1$ & $-0,2$ \\
Chemie & 117.000 & $-2,2$ & $-1,3$ \\
Metalektro & 396.000 & 0,0 & $-1,9$ \\
Overige industrie & 358.000 & 1,3 & $-1,2$ \\
Energie & 52.500 & $-2,1$ & 0,4 \\
Bouw & 546.500 & 2,1 & $-0,6$ \\
Handel & 1.041 .500 & 1,1 & 0,4 \\
Transport en communicatie & 429.000 & 1,3 & $-1,0$ \\
Bank en verzekering & 280.500 & 2,1 & 1,3 \\
Horeca en zakelijke dienstverlening & 1.163 .500 & 5,0 & 0,6 \\
Kwartaire diensten & 1.179 .500 & 3,5 & 1,1 \\
Overheid en onderwijs & 1.008 .000 & 2,5 & 1,0 \\
Totaal & & & 0,2 \\
\hline Bron: ROA(POA)/CPB(CEP.MLT)/CBS(EBB) & & 2,2 & \\
\hline
\end{tabular}

Bron: ROA(POA)/CPB(CEP,MLT)/CBS(EBB)

In tabel 2.2 worden de verschuivingen in de werkgelegenheid verbijzonderd naar beroepssector. Hieruit blijkt dat de werkgelegenheid in de technische en industrieberoepen en vooral de agrarische beroepen inderdaad behoorlijk krimpt. Dat betekent ook dat vooral de werkenden in deze beroepen worden geconfronteerd met de gevolgen de verschuivingen in de werkgelegenheidsstructuur. Omscholing gericht op ander werk zou voor degenen die het niet meer lukt om in hun eigen beroepssector nieuw werk te vinden mogelijk soelaas kunnen bieden om zich op de arbeidsmarkt te kunnen handhaven.

In de agrarische beroepen wordt er met name voor de werkenden in de beroepsgroepen agrarische bedrijfshoofden (de zelfstandige boeren) en landbouwmachinebestuurders en vissers voor de komende jaren een sterke werkgelegenheidskrimp verwacht. Bij de technische beroepen zal de werkgelegenheidskrimp zich voordoen in diverse beroepsgroepen. Zo wordt er een werkgelegenheidskrimp verwacht voor de mechanisch operators die werkzaam zijn in de voedingsindustrie en de handel. Daarnaast zal de werkgelegenheid voor grafische vakkrachten, die werkzaam zijn in de grafische industrie, naar verwachting dalen. Ook wordt er werkgelegenheidskrimp verwacht voor productiemedewerkers. De werkgelegenheidskrimp in deze beroepsgroep heeft vooral betrekking op lage functies in de bouw (sjouwer, hulparbeider wegenbouw, e.d.) en in de handel. Ten slotte wordt er ook werkgelegenheidskrimp verwacht voor de beroepsgroep werktuigbouwkundig ontwerpers en hoofden technische dienst. Deze beroepsgroep is met name werkzaam in de metalektro en in de zakelijke dienstverlening. Bij de transportberoepen wordt er met name voor de beroepsgroep schippers en conducteurs werkgelegenheidskrimp verwacht.

Ook binnen de beroepssectoren waarvoor per saldo voor de komende jaren een toename van de werkgelegenheid wordt verwacht, is er een aantal beroepsgroepen waarvoor de werkgelegenheid waarschijnlijk zal krimpen. Het gaat hier met name om 
beroepsgroepen die werkzaam zijn in de handel (winkeliers en technisch-comercieel employés) en in de sector horeca en zakelijke dienstverlening (economen, café en snackbarhouders, technisch bedrijfskundig medewerkers en technisch systeemanalisten).

Tabel 2.3 geeft inzicht in de werkgelegenheidsontwikkelingen naar opleidingsniveau. Deze verschuivingen zijn niet alleen een gevolg van de verschuivingen in de bedrijfssector- en beroepenstructuur van de werkgelegenheid, maar kunnen ook een gevolg zijn van de verschuivingen in gevraagde competenties binnen bepaalde beroepsgroepen. Op de verschuivingen in de gevraagde competenties wordt in paragraaf 2.5 verder ingegaan.

Tabel 2.2

Ontwikkeling van het aantal werkenden per beroepssector 1998-2002 en de en de verwachte werkgelegenheidsontwikkelingen voor 2003-2008, gemiddelde jaarlijkse percentages

\begin{tabular}{|c|c|c|c|}
\hline Beroepsklasse & $\begin{array}{l}\text { Aantal werkenden } \\
\text { gemiddelde } \\
\text { 2001-2002 }\end{array}$ & $\begin{array}{c}1998-2002 \\
\%\end{array}$ & $\begin{array}{c}2003-2008 \\
\%\end{array}$ \\
\hline $\begin{array}{l}\text { Pedagogisch } \\
\text { Cultureel } \\
\text { Agrarisch } \\
\text { Technisch en industrie } \\
\text { Transport } \\
\text { Medisch en paramedisch } \\
\text { Economisch- administratief } \\
\text { Informatica } \\
\text { Sociaal-cultureel } \\
\text { Verzorgend en dienstverlenend } \\
\text { Openbare orde en veiligheid }\end{array}$ & $\begin{array}{r}376.500 \\
134.000 \\
236.000 \\
1.481 .500 \\
409.000 \\
414.000 \\
2.081 .500 \\
281.500 \\
229.500 \\
1.152 .500 \\
116.500\end{array}$ & $\begin{array}{r}3,6 \\
1,1 \\
-2,9 \\
0,0 \\
2,5 \\
3,1 \\
2,4 \\
10,7 \\
3,7 \\
2,7 \\
0,4\end{array}$ & $\begin{array}{r}1,0 \\
0,9 \\
-1,8 \\
-0,5 \\
-0,1 \\
0,6 \\
0,2 \\
2,1 \\
0,8 \\
0,7 \\
0,4\end{array}$ \\
\hline Totaal & 7.102 .500 & 2,2 & 0,2 \\
\hline
\end{tabular}

Bron: ROA(POA)/ CBS(EBB)

Tabel 2.3 laat zien dat de afgelopen jaren de werkgelegenheid van zowel lager als hoger opgeleiden de afgelopen jaren is toegenomen. Hierbij is het zeer opmerkelijk dat de werkgelegenheid van mensen met alleen basisonderwijs (de 'ongeschoolden') de afgelopen jaren zelfs sterker is toegenomen dan het aantal werkenden met een MBO opleiding. Lager opgeleiden blijken in de hoogconjunctuur aan het eind van de jaren negentig te hebben geprofiteerd van het tekortschietende aanbod van mensen met een vakdiploma op MBO niveau. ${ }^{23}$ De komende jaren zullen mensen zonder een 'startkwalificatie' voor de arbeidsmarkt zich echter veel moeilijker op de arbeidsmarkt kunnen handhaven. Naar verwachting zal de werkgelegenheid voor werknemers met uitsluitend basisonderwijs de komende jaren sterk krimpen met maar liefst meer dan $5 \%$ per jaar. Een krimpende werkgelegenheid wordt ook verwacht voor de werkenden met een $\mathrm{VMBO}$ opleiding, maar voor hen wordt een minder drastische werkgelegenheidskrimp verwacht. Niettemin wijzen de cijfers uit tabel 2.3 voor de komende jaren op een duidelijke upgrading van het op de arbeidsmarkt gevraagde opleidingsniveau. De vraag naar mensen met een HAVO/VWO, MBO, HBO of WO opleiding

23. Zie A. de Grip \& S. Dijksman (2004), Winnaars en verliezers op de arbeidsmarkt 19952000, Tijdschrift voor Arbeidsvraagstukken, 20, (verschijnt binnenkort). 
neemt naar verwachting de komende jaren verder toe. Door dit upgradingsproces zullen de werkenden die geen opleiding hebben op MBO niveau of hoger de komende jaren geconfronteerd worden met een verhoogd risico op verlies van werk als gevolg van verschuivingen in de werkgelegenheidsstructuur.

Tabel 2.3

Ontwikkeling van het aantal werkenden per opleidingsniveau 1998-2002 en de verwachte werkgelegenheidsontwikkelingen voor 2003-2008, gemiddelde jaarlijkse percentages

\begin{tabular}{lccc}
\hline Opleidingsniveau & $\begin{array}{c}\text { Aantal werkenden } \\
\text { Gemiddelde } \\
2001-2002\end{array}$ & $\begin{array}{c}1998-2002 \\
\%\end{array}$ & $\begin{array}{c}2003-2008 \\
\%\end{array}$ \\
\hline Basisonderwijs & 560.000 & 2,3 & $-5,2$ \\
VMBO & 1.308 .500 & 0,2 & $-1,4$ \\
HAVO/ VWO & 399.000 & 3,9 & 1,8 \\
MBO & 2.504 .500 & 0,1 & 0,8 \\
HBO & 1.258 .500 & 3,3 & 1,5 \\
WO & 575.000 & 3,5 & 1,5 \\
Totaal & 7.102 .500 & 2,2 & 0,2 \\
\hline
\end{tabular}

Bron: ROA(POA)/ CBS(EBB)

\subsection{Verschuivingen in de gevraagde competenties}

De verschillende ontwikkelingen die in dit hoofdstuk aan de orde zijn gekomen hebben vanzelfsprekend ook hun uitwerking op de competenties die werkenden nodig hebben om hun werk goed te kunnen uitvoeren. Dit geldt met name voor de technologische en organisatorische veranderingen die een belangrijke oorzaak kunnen zijn van functie-inhoudelijke competentieveroudering en de verschuivingen in de sector- en beroepenstructuur van de werkgelegenheid. Om een indicatie te krijgen van de mate waarin er in de verschillende bedrijfssectoren sprake is van verschuivingen in de gevraagde competenties, is er op basis van de schoolverlatersgegevens van het ROA gekeken in hoeverre de in de verschillende bedrijfssectoren gevraagde competenties tussen 1998 en 2001 zijn veranderd. ${ }^{24}$ Daarbij kijken we naar de volgende competenties:

- Vakkennis;

- Gebruik van vakkennis in de praktijk;

- IT vaardigheden;

- Plannen en organiseren;

24. De informatie heeft betrekking op de gediplomeerde schoolverlaters van $M B O$ (BOL/BBL), $\mathrm{HBO}$ en WO. Er wordt dus alleen gekeken naar de competentieverschuivingen waarmee werkenden die over een startkwalificatie beschikken worden geconfronteerd. Verschuivingen in de gevraagde competenties aan de onderkant van de arbeidsmarkt blijven daarbij buiten beeld. De in kaart gebrachte verschuivingen in de op de arbeidsmarkt gevraagde competenties geven echter een goed richtsnoer voor de competentie-eisen waaraan ook de laag geschoolden moeten voldoen, om zich op startkwalificatieniveau duurzaam op de arbeidsmarkt te kunnen handhaven. 
- Communicatieve vaardigheden;

- Werken in teamverband;

- Zelfstandigheid;

- Initiatief/creativiteit;

- Aanpassingsvermogen;

- Nauwkeurigheid.

De verschuivingen van de gevraagde competenties worden in kaart gebracht door in zowel 1998 als 2001 in alle bedrijfssectoren de gemiddelde score te berekenen met betrekking tot het belang van een bepaalde competentie voor het goed kunnen functioneren in de functie die men uitoefent ${ }^{25}$ en vervolgens de procentuele verandering tussen deze twee jaargemiddelden te bepalen. Hoewel de gebruikte informatiebron feitelijk alleen betrekking heeft op de aan de nieuwkomers op de arbeidsmarkt gevraagde competenties, mag worden aangenomen dat de gesignaleerde verschuivingen in de gevraagde competenties ook hun impact zullen hebben op de competentie-eisen die gesteld worden aan diegenen die reeds langere tijd op de arbeidsmarkt actief zijn.

Figuur 2.6 geeft een overzicht van de mate waarin er in de verschillende sprake was van een toename van de vraag naar bepaalde competenties. De figuur geeft voor iedere bedrijfssector de geaggregeerde verschuivingen weer in het belang c.q. gebruik van de hierboven genoemde competenties. De verschuivingen in de gevraagde competenties blijken het grootst te zijn in de landbouw en visserij, de energiesector en in de overige industrie. In de handel, de chemie en in de transport en communicatiesector zijn de verschuivingen daarentegen betrekkelijk gering. Het is enigszins opmerkelijk dat de rangschikking van de sectoren in figuur 2.6 duidelijk verschilt van het patroon in figuur 2.5, waarin technologische en organisatorische ontwikkelingen centraal staan. Dat betekent dat de geconstateerde technologische en organisatorische veranderingen in de verschillende bedrijfssectoren sterk uiteenlopende gevolgen kunnen hebben voor de gevraagde competenties. Zo blijkt dat, hoewel de technologische en organisatorische ontwikkelingen in de landbouwsector relatief beperkt zijn, deze ontwikkelingen wél grote gevolgen hebben voor de gevraagde competenties van de werkenden in deze sector. Overigens zou dit ook kunnen samenhangen met de verschuivingen in de beroepenstructuur binnen de landbouwsector voor zover de werkgelegenheidskrimp in deze sector zich concentreert in bepaalde beroepsgroepen.

Tabel 2.4 geeft een overzicht van de competenties die tussen 1998 en 2001 in de verschillende bedrijfssectoren belangrijker zijn geworden. Over het algemeen valt op hoe goed de matrix is gevuld. Dit geeft duidelijk aan dat er op verschillende terreinen duidelijk sprake is van toenemende competentie-eisen, met een duidelijk accent op de toenemende eisen ten aanzien van de vakkennis waarover iemand moet beschikken en de mate waarin men in staat is om deze vakkennis goed toe te kunnen passen.

25. Bij de HBO'ers en universitair opgeleiden gaat het om de mate waarin men een bepaalde competentie in het werk gebruikt. 
Figuur 2.6

Totale verschuivingen in de gevraagde competenties per bedrijfssector, 1998-2001

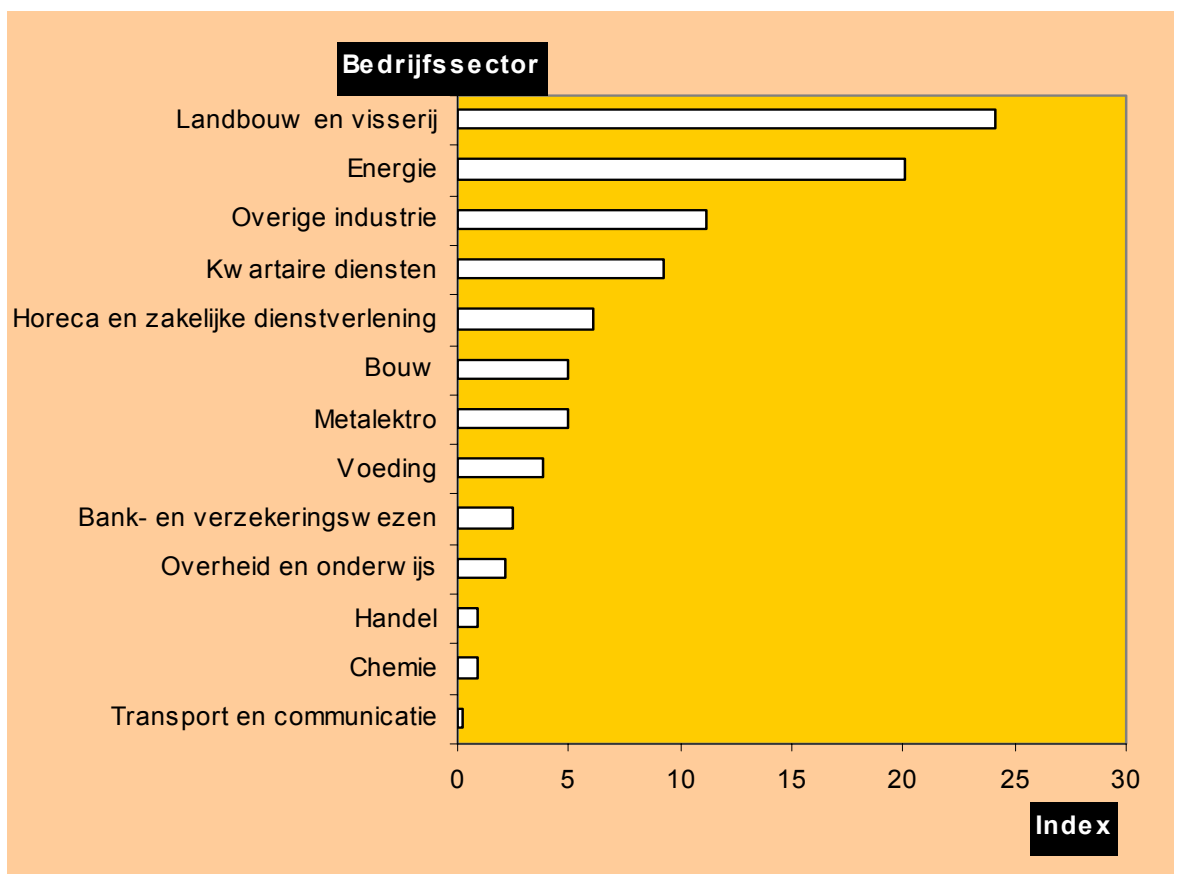

Bron: SIS (ROA)

In de landbouw en visserij zijn vakkennis, IT, plannen en organiseren en communicatieve vaardigheden belangrijker geworden. In de sectoren voeding, chemie en handel is met name het gebruik van vakkennis in de praktijk in belang toegenomen. In de metalektro, bouw en horeca en zakelijke dienstverlening neemt daarentegen zowel het belang van de vakkennis zelf als het gebruik ervan in de praktijk toe. In de energiesector worden IT-vaardigheden, het kunnen plannen en organiseren en nauwkeurigheid belangrijker, maar de grootste verschuiving vindt in deze sector plaats bij het gebruik van vakkennis in de praktijk. In de transport en communicatiesector is alleen het belang van communicatieve vaardigheden toegenomen. In het bank- en verzekeringswezen is daarentegen maar liefst een viertal competenties belangrijker geworden: Vakkennis, communicatieve vaardigheden, het kunnen werken in teamverband en zelfstandigheid. In de kwartaire diensten worden vakkennis, het kunnen plannen en organiseren, maar vooral ook IT-vaardigheden, belangrijker. In de sector overheid en onderwijs nemen plannen en organiseren, werken in teamverband en nauwkeurigheid in belang toe. 


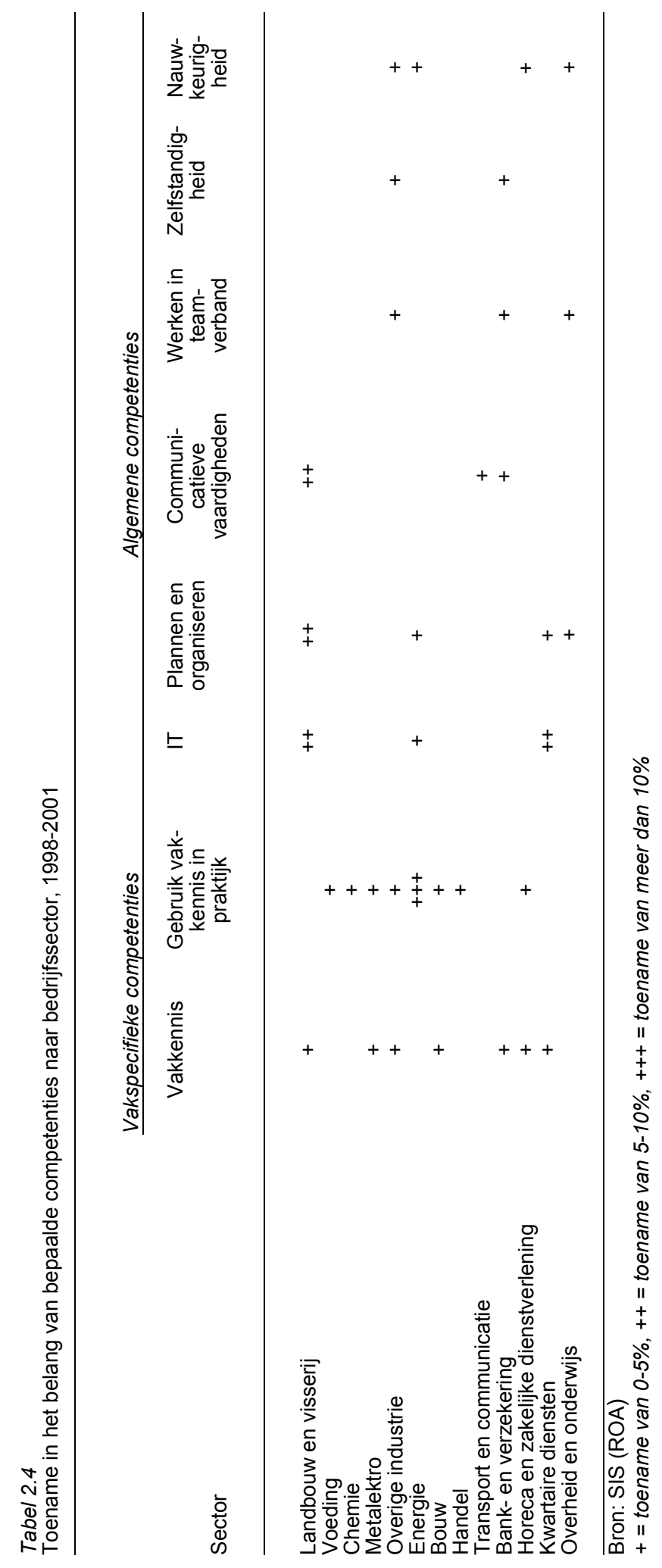


Figuur 2.7

Totale verschuivingen in belang van competenties naar bedrijfssector en opleidingsniveau, 1998-2001

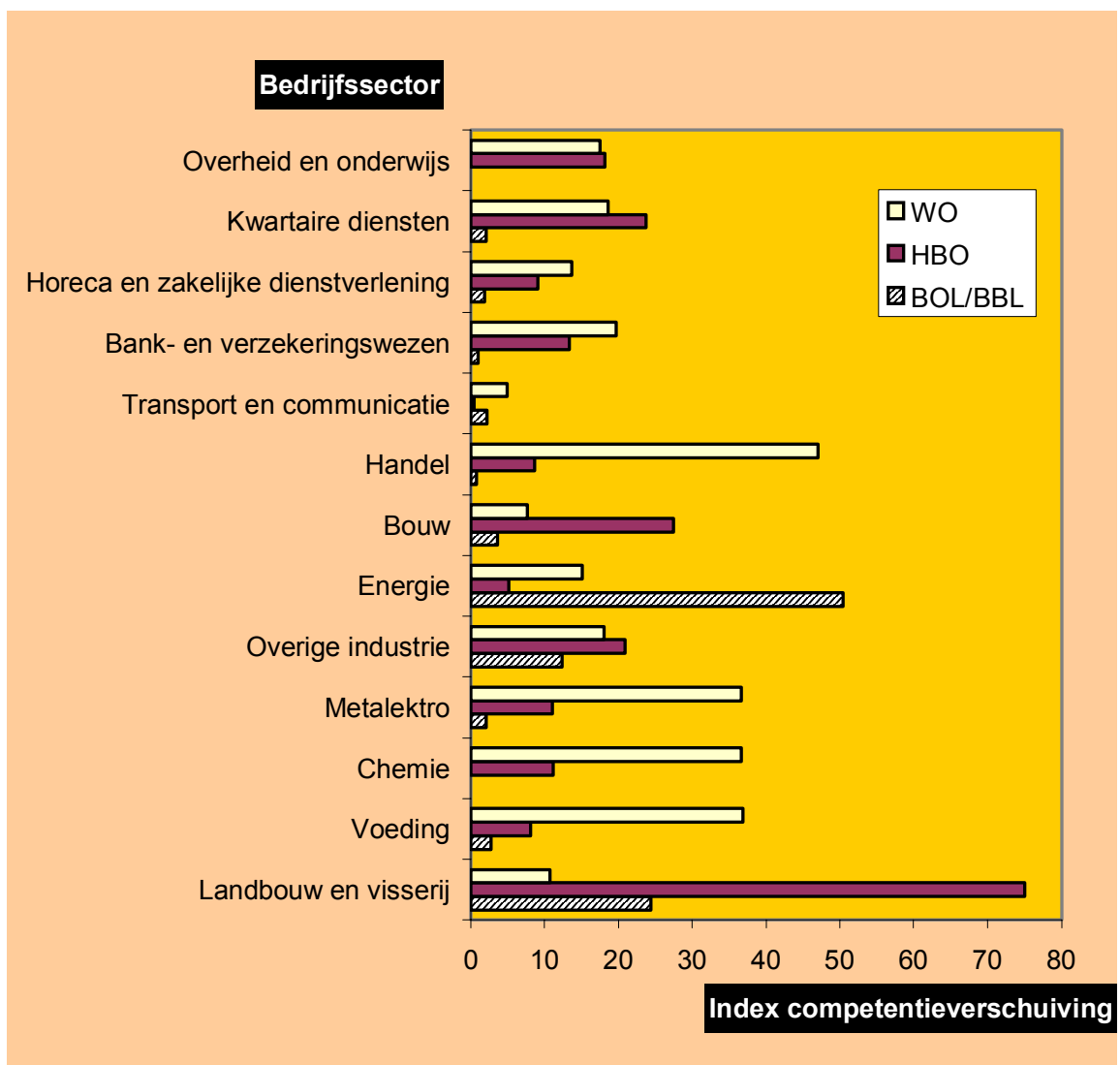

Bron: SIS (ROA)

Figuur 2.7 laat zien in hoeverre de gevraagde competenties in de verschillende bedrijfssectoren zijn verschoven al naar gelang het opleidingsniveau van de werkenden. Daarbij wordt er gekeken naar de werkenden met een BOL/BBL opleiding op MBO niveau, HBO'ers en academici. De figuur laat zien dat er tussen de onderscheiden opleidingsniveaus duidelijke verschillen zijn in de mate waarin men in de verschillende sectoren geconfronteerd wordt met verschuivingen in de gevraagde competenties. In de meeste industriële sectoren zijn de verschuivingen het grootst voor de werkenden met een universitaire opleiding. Alleen in de sector energie zijn de verschuivingen het grootst voor werknemers met een BOL/BBL opleiding. In de kwartaire sector, de sector overige industrie, de bouw en de agrarische sector zijn de verschuivingen het grootst voor de HBO'ers.

Voor werkenden met een BOL of BBL opleiding zijn de verschuivingen in de gevraagde competenties het grootst in de energiesector en in de landbouw en visserij. HBO'ers hebben met name in de landbouw en visserij en in de bouwsector 
met behoorlijke verschuivingen in de gevraagde competenties te maken. Voor academici vindt er in relatief veel bedrijfssectoren een aanzienlijke verschuiving in de gevraagde competenties plaats. De grootste verschuivingen in de gevraagde competenties doen zich bij de academici echter voor in de handel en industrie.

Tabel 2.5 geeft een beeld van de toename van het belang van de gevraagde competenties vanuit het perspectief van de verschillende beroepssegmenten, waarbij ook wordt verbijzonderd naar de verschillende opleidingsniveaus. Als we de tabel vergelijken met tabel 2.4 blijkt duidelijk dat wanneer we de verschuivingen in de gevraagde competenties verbijzonderen naar zowel de beroepssector als het opleidingsniveau, de verschuivingen in de gevraagde competenties nog veel groter zijn dan uit de ontwikkelingen op sectorniveau blijkt. Dit geeft aan dat er in veel bedrijfssectoren een duidelijke diversiteit is in de ontwikkeling van de gevraagde competenties in de verschillende beroepssectoren, waardoor bepaalde verschuivingen op sectorniveau tegen elkaar wegvallen. Daarnaast zijn er in de meeste beroepssectoren duidelijke verschillen in de verschuivingen in de gevraagde competenties voor de werkenden met een $\mathrm{MBO}, \mathrm{HBO}$ of universitair opleidingsniveau.

De tabel laat zien dat er in alle beroepssectoren sprake is van een toenemend belang van zowel de vakspecifieke als de meer algemene competenties. Alleen in de culturele beroepen is er vooral sprake van verschuivingen in de gevraagde algemene competenties, met name op het terrein van IT vaardigheden, plannen en organiseren en communicatieve vaardigheden. Vooral in de pedagogische beroepen, agrarische beroepen en trasportberoepen zijn de verschuivingen in de gevraagde competenties groot, met name voor de in deze sectoren werkzame HBO'ers.

Vakkennis is met name voor de werkenden met een BOL/BBL opleiding en de HBO'ers in de agrarische beroepen en voor HBO'ers met een transportberoep belangrijker geworden. Het gebruik van vakkennis in de praktijk is voor BOL/BBL'ers die werkzaam zijn in een agrarisch, transport, informatica of sociaal- cultureel beroep belangrijker geworden. IT vaardigheden zijn in veel beroepen voor alle opleidingsniveaus belangrijker geworden. Plannen en organiseren is met name voor hoger opgeleiden die werkzaam zijn in een agrarisch beroep en voor HBO'ers met een transportberoep in belang toegenomen. Voor HBO'ers met een agrarisch beroep zijn communicatieve vaardigheden belangrijker geworden. Het werken in teamverband is vooral voor de HBO'ers die werkzaam zijn in de pedagogische beroepen of transportberoepen belangrijker geworden. Voor die laatste groep is ook het zelfstandig werken in belang toegenomen. Het beschikken over een goed aanpassingsvermogen is vooral voor diegenen met een BOL/BBL opleiding in de pedagogische en agrarische beroepen en voor de HBO'ers met een agrarisch beroep in belangrijker geworden. Het belang van nauwkeurigheid is met name voor de hoger opgeleiden die werkzaam zijn in de pedagogische beroepen toegenomen. 


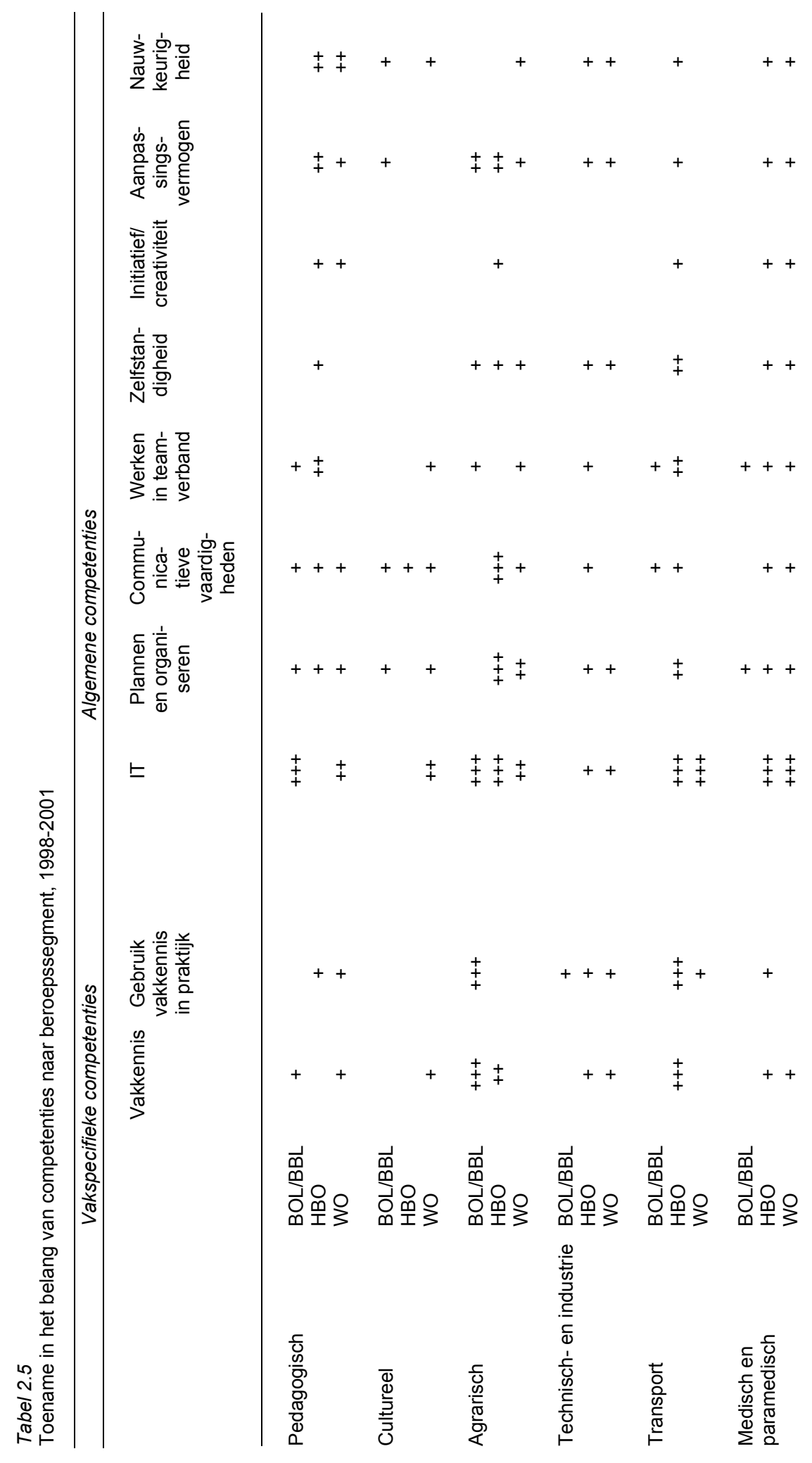




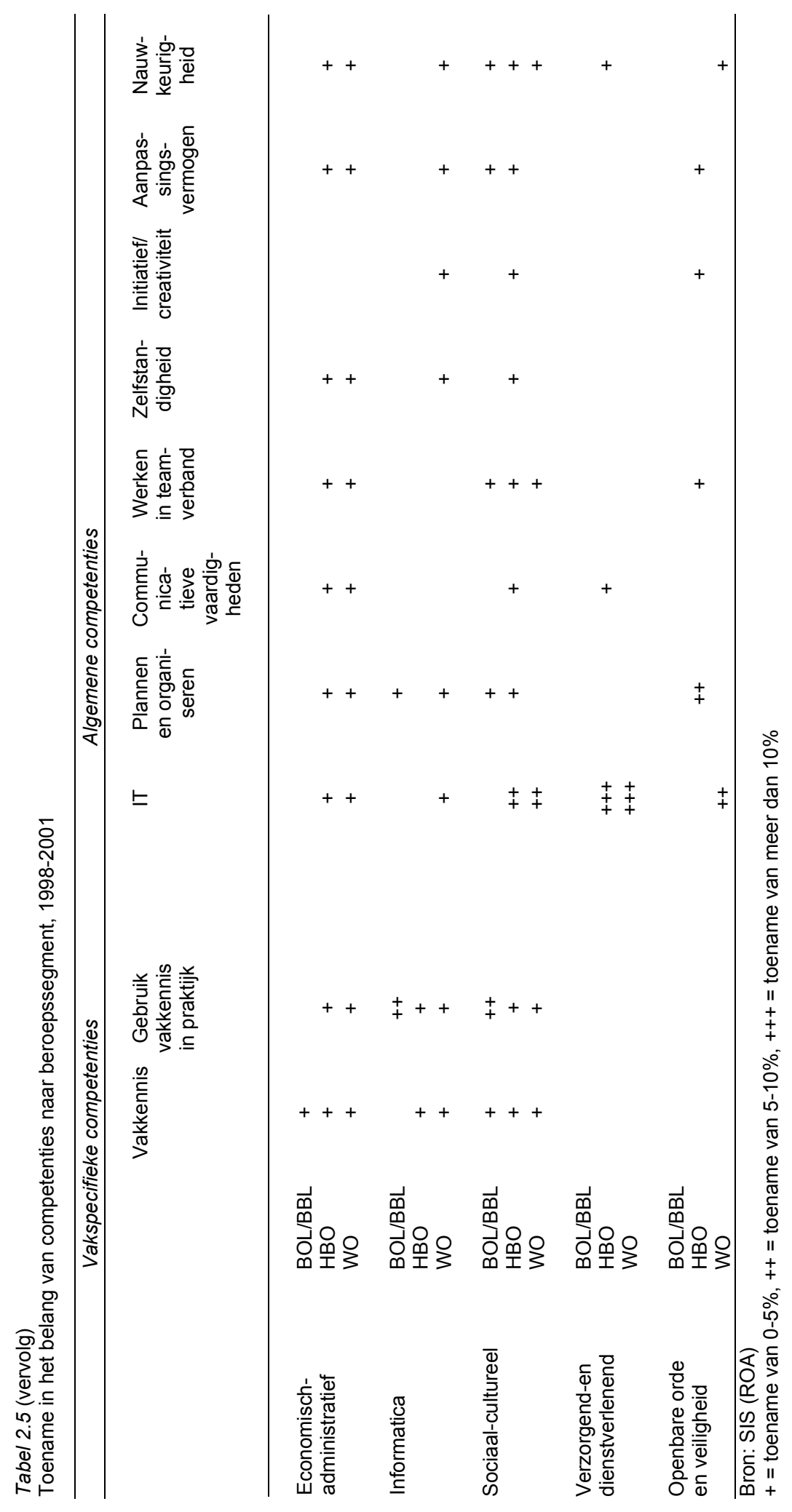




\subsection{Samenvatting}

Competentieveroudering kan uiteenlopende oorzaken hebben. In dit hoofdstuk is een overzicht gegeven van de mate waarin de belangrijkste risicofactoren zich in de verschillende bedrijfssectoren voordoen en de specifieke beroepsgroepen en opleidingscategorieën die binnen de sector met name met een risico op verlies van werk vanwege competentieveroudering te kampen hebben. Daarbij gaat het achtereenvolgens om de volgende risicofactoren:

- De mate waarin werknemers in hun werk worden geconfronteerd met fysiek en/of psychisch belastende arbeidsomstandigheden.

- De mate waarin technologische en organisatorische ontwikkelingen het werk veranderen.

- Ontwikkelingen in de structuur van de werkgelegenheid die invloed hebben op het voortbestaan van bepaalde functies en banen.

De fysieke belasting tijdens het werk is al jaren het hoogst in de bouw. De metalektro en landbouw en visserij volgen, net als in voorgaande jaren, op enige afstand. Opvallend is de toename van de fysieke belasting van de werkenden in de voedingsindustrie. Het zijn vooral de laag opgeleiden die werkzaam zijn in de technische beroepen en de verpleegkundigen die worden geconfronteerd met een verhoogd risico op competentieveroudering vanwege belastende arbeidsomstandigheden. Dat zijn opmerkelijk genoeg ook de groepen waarvoor de knelpunten op de arbeidsmarkt vooral op MBO niveau structureel het grootst zijn.

Meer aandacht voor het ARBO beleid in de bedrijfssectoren waar de fysieke belasting voor de werkenden groot is, zou er voor kunnen zorgen dat de mensen die in deze sectoren werkzaam zijn zich langer in hun functie kunnen handhaven. Bovendien wordt het werk in deze bedrijfssectoren hierdoor aantrekkelijker voor jongeren. Dit kan er toe bijdragen dat weer meer scholieren kiezen voor technische en verpleegkundige opleidingen.

Een op doorstroom gericht scholingsbeleid in deze sectoren zou de aantrekkingskracht van de technische en verpleegkundige opleidingen nog kunnen vergroten, doordat door het bieden van een helder doorstroomperspectief het beeld wordt weggenomen dat het voor de werkenden op deze segmenten van de arbeidsmarkt vanwege de fysiek belastende arbeidsomstandigheden moeilijk is om op de langere termijn hun employability op peil te houden.

De tijdsdruk waaronder er gewerkt moet worden is sinds het jaar 2000 in vrijwel alle sectoren wat afgenomen. De tijdsdruk is nog altijd het hoogst in de transportsector, waar met name vliegers, scheepskapiteins en leidinggevenden, productieplanners en managers vaak onder hoge tijdsdruk moeten werken. Datzelfde geldt voor journalisten en kunstenaars in de kwartaire dienstensector.

Over het algemeen zijn het met name de hoger opgeleiden die vaak te maken hebben met een hoge tijdsdruk tijdens hun werk. De tijdsdruk is het hoogst onder de 
werkenden in de zakelijke dienstverlening met een opleiding accountancy en belastingen of rechten en bestuurskunde op WO niveau. In de kwartaire sector werken de werkenden met een medische opleiding op universitair niveau het meest onder hoge tijdsdruk. In de transportsector zijn het echter juist de werkenden met een lagere of middelbare opleiding waar de psychische belasting vanwege de hoge tijdsdruk waaronder men moet werken het grootst is.

Behalve een hoge tijdsdruk kan ook 'agressief gedrag' van klanten, collega's of chefs voor een hoge psychische belasting zorgen. Daarbij gaat het om:

- Ongewenste seksuele aandacht;

- Intimidatie (bedreigingen, chantage);

- Lichamelijk geweld (slaan, schoppen, vastgrijpen).

Agressief gedrag van klanten of patiënten treft vooral de werkenden in de kwartaire dienstensector (w.o. de gezondheidszorg) en de handel. Agressief gedrag van chefs of collega's komt het meest voor in de chemie en het bank- en verzekeringswezen. Agressief gedrag, pestgedrag en seksuele intimidatie van klanten of collega's leidt in veel gevallen tot verlies van werk. Goede (team)trainingen en trainingen gericht op het bestrijden van agressie en geweld kunnen werknemers weerbaarder maken, zodat zij minder vaak vroegtijdig de arbeidsmarkt verlaten.

Een van de steeds belangrijker wordende oorzaken van ziekteverzuim en vroegtijdige arbeidsmarktuitstroom is RSI. Het regelmatig verrichten van beeldschermwerk is de laatste jaren een belangrijke veroorzaker van RSI. De risico's op verlies van werk zijn met name groot wanneer mensen die regelmatig beeldschermwerk verrichten ook onder een hoge tijdsdruk moeten werken.

In het bank- en verzekeringswezen wordt verreweg het meeste beeldschermwerk verricht. Op enige afstand volgen de energiesector en de sectoren horeca en zakelijke dienstverlening en overheid en onderwijs. Het spreekt voor zich dat vooral werkenden in de informaticaberoepen regelmatig beeldschermwerk verrichten. Bij de werkenden in informaticaberoepen is er echter alleen in de handel - en dan met name voor de systeemanalisten - sprake van de risicovolle combinatie van regelmatig beeldschermwerk en een erg hoge tijdsdruk. Ook voor de juristen die werkzaam zijn in het bank- en verzekeringswezen en de accountants binnen de zakelijke dienstverlening zijn de risico's op arbeidsuitval vanwege RSI hoog, omdat men regelmatig beeldschermwerk verricht en onder hoge tijdsdruk moet werken. Hetzelfde geldt voor de journalisten die werkzaam zijn in de grafische industrie en productieplanners in de transportsector.

Technologische en organisatorische ontwikkelingen hebben een grote invloed op de inhoud van het werk. De werkenden in het bank- en verzekeringswezen worden het meest geconfronteerd met technologische en organisatorische ontwikkelingen. De sector onderscheidt zich vooral door het hoge percentage bedrijven dat het dienstenaanbod de afgelopen jaren ingrijpend heeft veranderd, het grote aantal fusies, overnames en interne reorganisaties, de hoge informatiseringsgraad en het grote aandeel van de werkenden dat de inhoud van hun werk door proces- 
vernieuwingen heeft zien veranderen. De sector overheid en onderwijs, waar na het bank- en verzekeringswezen de meeste ontwikkelingen plaatsvinden, kenmerkt zich met name door een hoge mate van informatisering, het veranderen van de inhoud van het werk door procesvernieuwingen, een fors aantal interne reorganisaties en ingrijpende veranderingen in het dienstenpakket.

De verschuiving van de werkgelegenheid van de industrie naar de dienstensector wordt de afgelopen jaren steeds beter zichtbaar. In de landbouw en industriële sectoren is sprake van een voortgaande werkgelegenheidskrimp, terwijl in dienstensectoren als het bank- en verzekeringswezen, de horeca en zakelijke dienstverlening, overheid en onderwijs en de kwartaire diensten de werkgelegenheid de laatste jaren weer verder is toegenomen. Deze verschuiving in de sectorstructuur van de werkgelegenheid weerspiegelt zich ook in de beroepenstructuur. In de technische en industrieberoepen, de transportberoepen en de agrarische beroepen krimpt de werkgelegenheid. Werkenden in deze beroepen lopen daardoor het risico te maken te krijgen met verlies van werk omdat hun competenties hun marktwaarde verliezen. Dit is met name het geval voor de lagere opleidingsniveaus, aangezien er in alle sectoren sprake is van een upgrading van het voor het werk vereiste opleidingsniveau. De vraag naar mensen met alleen basisonderwijs of een VMBO opleiding neemt hierdoor sterk af, terwijl de vraag naar mensen met een MBO, HBO of WO de komende jaren weer verder toeneemt.

Om een indicatie te krijgen van de mate waarin er in de verschillende bedrijfssectoren sprake is van verschuivingen in de gevraagde competenties, is nagegaan in hoeverre er een toenemende vraag is naar vakspecifieke en meer algemene competenties. De toename van het belang van de verschillende competenties is het grootst in de landbouwsector, gevolgd door de energiesector. In de agrarische sector zijn vakkennis en het gebruik ervan in de praktijk, IT, plannen en organiseren en communicatieve vaardigheden belangrijker geworden. In de energiesector worden IT-vaardigheden, het kunnen plannen en organiseren en nauwkeurigheid belangrijker om goed te kunnen functioneren in het werk. Het blijkt dat er in alle beroepssectoren sprake is van een toenemend belang van zowel de vakspecifieke als de meer algemene competenties. Alleen in de culturele beroepen is er vooral sprake van verschuivingen in de gevraagde algemene competenties, met name op het terrein van IT vaardigheden, plannen en organiseren en communicatieve vaardigheden. Vooral in de pedagogische beroepen, agrarische beroepen en transportberoepen zijn de verschuivingen in de gevraagde competenties groot. Ten slotte zijn er ook duidelijke verschillen in de mate waarin de werkenden met een verschillend opleidingsniveau in een sector geconfronteerd worden met een verschuiving in de gevraagde competenties. In de industriële sectoren zijn de verschuivingen het grootst voor de universitair opgeleiden. In de kwartaire sector, de sector overige industrie, de bouw en de agrarische sector zijn de verschuivingen daarentegen het grootst voor HBO'ers.

In schema 2.1 wordt, verbijzonderd naar bedrijfssector, een overzicht gegeven van de beroepsgroepen waarin de werkenden het meest geconfronteerd worden met een bepaalde risicofactor. Uit het schema blijkt dat bepaalde beroepsgroepen met 
meerdere risicofactoren worden geconfronteerd. Ook blijkt dat niet alleen de werkenden in de lagere functies het risico lopen dat ze zich op een bepaald moment niet meer in hun functie kunnen handhaven. Met name in de 'dienstverlenende beroepen' en de 'kantoorberoepen', waarin momenteel het grootste deel van de beroepsbevolking werkzaam is, zijn er verschillende risicofactoren die tot vroegtijdige arbeidsmarktuitstroom kunnen leiden. De werkenden in de dienstverlenende beroepen worden vaak geconfronteerd met risico's van tijdsdruk en agressief gedrag van klanten terwijl de kantoorberoepen risico's lopen vanwege beeldschermwerk, tijdsdruk en de veranderingen in het werk vanwege technologische en organisatorische vernieuwingen.

\section{Schema 2.1}

Beroepsgroepen met een hoog risico op competentieveroudering vanwege belastende arbeidsomstandigheden, RSI, tijdsdruk, technologische en organisatorische ontwikkelingen of een krimpende werkgelegenheid

\begin{tabular}{|c|c|c|}
\hline Bedrijfssector & Risicoberoepen: & Belastingsfactor(en $)^{*}$ \\
\hline Landbouw en visserij & $\begin{array}{l}\text { Agrarische bedrijfshoofden } \\
\text { landbouwmachinebestuurders en } \\
\text { vissers }\end{array}$ & $\begin{array}{l}\text { krimpende werkgelegenheid } \\
\text { krimpende werkgelegenheid }\end{array}$ \\
\hline Voedingsindustrie & $\begin{array}{l}\text { Monteurs } \\
\text { Chauffeurs } \\
\text { Mechanisch operators }\end{array}$ & $\begin{array}{l}\text { fysieke belasting } \\
\text { fysieke belasting, } \\
\text { krimpende werkgelegenheid }\end{array}$ \\
\hline Metalektro & $\begin{array}{l}\text { Bouwvakkers } \\
\text { Bankwerkers en lassers } \\
\text { Metaalarbeiders } \\
\text { Managers } \\
\text { Commercieel medewerkers } \\
\text { Werktuigbouwkundig ontwerpers en } \\
\text { hoofden technische dienst }\end{array}$ & $\begin{array}{l}\text { fysieke belasting } \\
\text { fysieke belasting } \\
\text { fysieke belasting } \\
\text { tijdsdruk } \\
\text { tijdsdruk } \\
\text { krimpende werkgelegenheid }\end{array}$ \\
\hline Overige industrie & $\begin{array}{l}\text { Journalisten } \\
\text { Grafische vakkrachten }\end{array}$ & $\begin{array}{l}\text { RSI } \\
\text { krimpende werkgelegenheid }\end{array}$ \\
\hline Bouw & $\begin{array}{l}\text { Bouwvakkers } \\
\text { Weg- en waterbouwkundige arbeiders } \\
\text { Productiemedewerkers } \\
\text { Architecten en bouwkundig } \\
\text { projectleiders }\end{array}$ & $\begin{array}{l}\text { fysieke belasting } \\
\text { fysieke belasting } \\
\text { krimpende werkgelegenheid } \\
\text { tijdsdruk }\end{array}$ \\
\hline Handel & $\begin{array}{l}\text { Winkeliers } \\
\text { Commercieel medewerkers } \\
\text { Technisch-commercieel employés } \\
\text { Mechanisch operators } \\
\text { Leidinggevenden } \\
\text { Systeemanalisten } \\
\text { Productiemedewerkers }\end{array}$ & $\begin{array}{l}\text { krimpende werkgelegenheid } \\
\text { tijdsdruk, agressief gedrag van } \\
\text { klanten } \\
\text { krimpende werkgelegenheid } \\
\text { krimpende werkgelegenheid } \\
\text { tijdsdruk, agressief gedrag van } \\
\text { klanten } \\
\text { RSI, agressief gedrag van } \\
\text { klanten } \\
\text { krimpende werkgelegenheid }\end{array}$ \\
\hline $\begin{array}{l}\text { Transport en } \\
\text { communicatie }\end{array}$ & $\begin{array}{l}\text { Managers } \\
\text { Productieplanners } \\
\text { Schippers en conducteurs } \\
\text { Vliegers, scheepskapiteins en } \\
\text { leidinggevenden in het transport } \\
\text { Leidinggevenden } \\
\text { Systeemanalisten }\end{array}$ & $\begin{array}{l}\text { tijdsdruk } \\
\text { RSI } \\
\text { krimpende werkgelegenheid } \\
\text { tijdsdruk } \\
\text { tijdsdruk, agressief gedrag van } \\
\text { klanten } \\
\text { RSI, agressief gedrag van } \\
\text { klanten }\end{array}$ \\
\hline
\end{tabular}


Schema 2.1 (vervolg)

Beroepsgroepen met een hoog risico op competentieveroudering vanwege belastende arbeidsomstandigheden, RSI, tijdsdruk, technologische en organisatorische ontwikkelingen of een krimpende werkgelegenheid

\begin{tabular}{|c|c|c|}
\hline Bedrijfssector & Risicoberoepen: & Belastingsfactor(en)* \\
\hline $\begin{array}{l}\text { Bank- en } \\
\text { verzekeringswezen }\end{array}$ & $\begin{array}{l}\text { Juristen } \\
\text { Commercieel employés } \\
\text { Receptionisten en administratieve } \\
\text { employés } \\
\text { Assistent accountants } \\
\text { Boekhouders en secretaresses } \\
\text { Accountants } \\
\text { Verzekeringsagenten } \\
\text { Programmeurs } \\
\text { Systeemanalisten } \\
\text { Informatici }\end{array}$ & $\begin{array}{l}\text { tijdsdruk, agressief gedrag van } \\
\text { collega's of leidinggevenden, } \\
\text { technologische en organi- } \\
\text { satorische vernieuwingen } \\
\text { technologische en organisa- } \\
\text { torische ontwikkelingen } \\
\text { technologische en organisa- } \\
\text { torische ontwikkelingen } \\
\text { technologische en organisa- } \\
\text { torische ontwikkelingen } \\
\text { technologische en organisa- } \\
\text { torische ontwikkelingen } \\
\text { technologische en organisa- } \\
\text { torische ontwikkelingen } \\
\text { technologische en organisa- } \\
\text { torische ontwikkelingen } \\
\text { technologische en organisa- } \\
\text { torische ontwikkelingen } \\
\text { technologische en organisa- } \\
\text { torische ontwikkelingen } \\
\text { technologische en organisa- } \\
\text { torische ontwikkelingen }\end{array}$ \\
\hline $\begin{array}{l}\text { Horeca en zakelijke } \\
\text { dienstverlening }\end{array}$ & $\begin{array}{l}\text { Winkeliers } \\
\text { Juristen } \\
\text { Organisatiedeskundigen } \\
\text { Leidinggevenden } \\
\text { Managers } \\
\text { Economen } \\
\text { Accountants } \\
\text { Café en snackbarhouders } \\
\text { Bedrijfshoofden horeca } \\
\text { Technisch-bedrijfskundig medewerkers } \\
\text { Werktuigbouwkundig ontwerpers en } \\
\text { hoofden technische dienst } \\
\text { Grafische vakkrachten } \\
\text { Technisch systeemanalisten }\end{array}$ & $\begin{array}{l}\text { krimpende werkgelegenheid } \\
\text { tijdsdruk } \\
\text { tijdsdruk } \\
\text { tijdsdruk } \\
\text { tijdsdruk } \\
\text { krimpende werkgelegenheid } \\
\text { RSI } \\
\text { krimpende werkgelegenheid } \\
\text { tijdsdruk } \\
\text { krimpende werkgelegenheid } \\
\text { krimpende werkgelegenheid } \\
\text { krimpende werkgelegenheid } \\
\text { krimpende werkgelegenheid }\end{array}$ \\
\hline Kwartaire diensten & $\begin{array}{l}\text { Managers } \\
\text { Journalisten } \\
\text { Kunstenaars } \\
\text { Artsen } \\
\text { Afdelingshoofden van zorginstelling } \\
\text { Ziekenverzorgenden } \\
\text { Hoofden sociaal-cultureel werk en p\&a } \\
\text { Onderwijskundigen/ pedagogen }\end{array}$ & $\begin{array}{l}\text { tijdsdruk, agressief gedrag van } \\
\text { klanten } \\
\text { tijdsdruk, agressief gedrag van } \\
\text { klanten } \\
\text { tijdsdruk, agressief gedrag van } \\
\text { klanten } \\
\text { tijdsdruk, agressief gedrag van } \\
\text { klanten } \\
\text { fysieke belasting, tijdsdruk, } \\
\text { agressief gedrag van klanten } \\
\text { tijdsdruk, agressief gedrag van } \\
\text { klanten } \\
\text { tijdsdruk, agressief gedrag van } \\
\text { klanten } \\
\text { tijdsdruk, agressief gedrag van } \\
\text { klanten }\end{array}$ \\
\hline
\end{tabular}


Schema 2.1 (vervolg)

Beroepsgroepen met een hoog risico op competentieveroudering vanwege belastende arbeidsomstandigheden, RSI, tijdsdruk, technologische en organisatorische ontwikkelingen of een krimpende werkgelegenheid

Bedrijfssector Risicoberoepen: Belastingsfactor(en)*

Overheid en onderwijs Managers

en-administratief

( $2^{\mathrm{e}}$ graads)

Verzekeringsagenten

Bibliothecarissen

Natuurwetenschappers

Weg- en waterbouwk. ontwerper/

projectleiders

Organisatie-adviseurs

Boekhouders en secretaresses

Assistent accountants

Accountants

Economen

Programmeurs

Systeemanalisten

Brandweerlieden

Informatici

tijdsdruk

tijdsdruk

\section{RSI}

technologische en

organisatorische ontwikkelingen

technologische en

organisatorische ontwikkelingen technologische en

organisatorische ontwikkelingen

technologische en

organisatorische ontwikkelingen

technologische en

organisatorische ontwikkelingen

technologische en

organisatorische ontwikkelingen

technologische en

organisatorische ontwikkelingen

krimpende werkgelegenheid

technologische en

organisatorische ontwikkelingen

technologische en

organisatorische ontwikkelingen

krimpende werkgelegenheid

technologische en

organisatorische ontwikkelingen

Sociaal- wetenschappelijk onderzoekers technologische en

organisatorische ontwikkelingen 



\section{Scholing}

\subsection{Inleiding}

In dit hoofdstuk zal in kaart worden gebracht in hoeverre de werkenden in de verschillende bedrijfssectoren zich wapenen tegen de risico's op verlies van werk vanwege competentieveroudering. De scholing van werkenden kan immers een grote rol spelen voor het op peil houden van de arbeidsproductiviteit en arbeidsparticipatie van de Nederlandse beroepsbevolking. De scholingsdeelname van werknemers verschilt echter over het algemeen sterk per bedrijfssector. De ene sector is kennisintensiever dan de andere en de ene sector wordt met meer veranderingen in het productieproces of veranderingen op afzetmarkten geconfronteerd dan de andere. Ook het beroep dat iemand uitoefent, heeft grote invloed op de scholingsparticipatie. In het ene beroep vinden regelmatig belangrijke veranderingen plaats, waarvoor voortdurend investeringen in nieuw menselijk kapitaal nodig zijn. In andere beroepen kunnen mensen daarentegen langere tijd goed functioneren zonder veel aanvullende scholing te moeten volgen.

In dit hoofdstuk wordt het scholingsbeleid van Nederlandse bedrijven en instellingen in beeld gebracht. Allereerst worden in paragraaf 3.2 enkele algemene indicatoren van de scholingsdeelname van werknemers in kaart gebracht. Daarbij komt de scholingsdeelname in het algemeen aan de orde, maar er wordt ook specifieker ingegaan op de verschillende soorten scholing die worden gevolgd, het doel van de gevolgde scholing, wie de scholing betaalt en of de scholing al dan niet in werktijd plaatsvindt. Daarna wordt in paragraaf 3.3 een overzicht gegeven van de groepen werkenden in de verschillende bedrijfssectoren voor wie geldt dat de deelname aan scholingstrajecten dusdanig beperkt is dat zij zich mogelijk niet voldoende hebben gewapend tegen de risico's van competentieveroudering, die in het vorige hoofdstuk zijn besproken. Vervolgens wordt in paragraaf 3.4 ingegaan op de rol van Opleidings- en Ontwikkelingsfondsen (O\&O) en Arbeidsmarkt- en Opleidingsfondsen (A\&O) voor het scholingsbeleid in de verschillende bedrijfssectoren. In aansluiting daarop wordt in paragraaf 3.5 ingegaan op het gebruik dat O\&O fondsen maken van middelen uit het Europese Sociale Fonds (ESF 3) ter ondersteuning van het sectorale scholingsbeleid. Paragraaf 3.6 sluit het hoofdstuk af met het in kaart brengen van 13 sectorprofielen, waarin voor elke sector een overzicht wordt gegeven van de scholingsparticipatie, de specifieke risico's op verlies van werk vanwege competentieveroudering en de mate waarin de sector gebruik maakt van ESF 3 subsidies voor scholingsactiviteiten die deze risico's zouden kunnen verminderen.

\subsection{Scholingsinspanningen}

Tabel 3.1 geeft een overzicht van de scholingsdeelname voor de periode 1998-2000 en 2000-2002, verbijzonderd naar bedrijfssector. Uit de tabel blijkt dat er over de 
gehele linie sprake is van een forse teruggang in de scholingsdeelname. In vrijwel alle sectoren neemt het percentage werkenden dat één of meerdere cursussen heeft gevolgd flink af. In de chemiesector zelf met maar liefst $24 \%$-punt. Ook in de overige industrie en de handel is de daling van de scholingsdeelname fors. De afnemende scholingsparticipatie van werkenden illustreert de vaak grote conjunctuurgevoeligheid van de scholingsinvesteringen in het bedrijfsleven. Kennelijk zien veel bedrijven zich genoodzaakt bij een inzakkende bedrijvigheid sterk op hun scholingsinvesteringen te bezuinigen. Dit kan zowel op de korte als op de wat langere termijn de risico's op verlies van werk van het personeel van deze bedrijven vergroten. Het is opmerkelijk dat de O\&O fondsen in veel sectoren nog nauwelijks tegenwicht kunnen bieden aan de bezuinigingen op de scholingsinvesteringen van de bedrijven in de sector. ${ }^{27}$

In de metalektro, een sector met grote en actieve sociale en O\&O fondsen, is de cursusdeelname tussen 1999 en 2001 met 10\%-punt gedaald tot 45\%. Onderzoek binnen deze sector naar de belemmeringen om deel te nemen aan cursussen laat zien dat vooral de kosten (geld én tijd) van cursussen voor bedrijven in de sector een belemmering vormen om werknemers aan cursussen te laten deelnemen. Meer dan $40 \%$ van de bedrijven wijst het gebrek aan tijd of geld aan als belangrijkste belemmering. Het tegenwicht van de aanwezige fondsen is dus ook in deze sector onvoldoende om de terugval in cursusdeelname helemaal te voorkomen of beperken. In paragraaf 3.4 zal hier verder op worden ingegaan. ${ }^{28}$

Alleen in de voedingssector werd tussen 2000 en 2002 meer scholing gevolgd dan in de periode 1998-2000. De voedingssector profileert zich daarmee na de energiesector, waar de scholingsparticipatie nagenoeg constant is gebleven, maar nog vóór het bank- en verzekeringswezen, als de sector met de hoogste scholingsdeelname. Dat is een opvallende prestatie gezien het feit dat de voedingssector in de periode 1998-2000 nog de sector was met de laagste scholingsparticipatie.

In de sectoren overige industrie, handel, landbouw en chemie wordt het minst aan opleidingen of cursussen deelgenomen. Ongeveer één op de drie werknemers in deze sectoren heeft in de periode 2000-2002 één of meerdere cursussen gevolgd. In de sector overige industrie wordt de geringe scholingsdeelname overigens enigszins gecompenseerd, doordat het aantal cursussen dat per werknemer wordt gevolgd op een gemiddeld niveau ligt en het aantal uren dat een werknemer aan cursussen heeft besteed zelfs aan de hoge kant is. Dit wijst er op dat in deze sector een relatief kleine groep werknemers veel tijd besteedt aan het volgen van cursussen. In de andere sectoren met een geringe scholingsdeelname - chemie, handel en landbouw - is dat minder het geval. In deze sectoren is ook het aantal gevolgde cursussen per werknemer en het gemiddelde aantal uren dat een werknemer aan cursussen besteedt het laagst.

27. In paragraaf 3.4 zal hierop verder worden ingegaan.

28. Stichting Arbeidsmarkt en Opleiding in de Metalektro (2003) Nieuwsbrief Arbeidsmarktmonitor Metalektro December 2003. 
Gemiddeld volgden werkenden in Nederland in de periode 2000-2002 ongeveer 0,8 cursus. Per werkende is in totaal in diezelfde periode ongeveer 11 uur aan cursussen besteed. De werkenden in de energiesector volgen gemiddeld de meeste cursussen: in twee jaar tijd wordt per werknemer bijna anderhalve cursus gevolgd. Het zijn echter de werknemers in de voedingssector en het bank- en verzekeringswezen die de meeste tijd aan cursussen hebben besteed: ruim 17 uur. De sector overheid en onderwijs volgt met gemiddeld 15,5 uur cursus per werkende. Net als in de energiesector volgen ook degenen die werkzaam zijn in het bank- en verzekeringswezen en de sector overheid en onderwijs gemiddeld iets meer dan één cursus in de periode 2000-2002. De werkenden in de landbouw en visserij, de chemie en de handel blijven met gemiddeld 0,6 cursus per werknemer wat achter op de overige bedrijfssectoren. Tussen deze sectoren is er overigens wel een behoorlijk verschil voor wat betreft het aantal uren dat een werknemer gemiddeld aan cursussen besteedt. In de chemie is dat ruim 11 uur. In de sector handel is dat een uur minder en in de landbouwsector per werkende zelfs ruim 3 uur minder.

De afname van de cursusdeelname komt voornamelijk voor rekening van de oudere leeftijdsgroepen. Van de werkenden in de leeftijdscategorie 56 tot 65 jaar volgde in de periode 1998-2000 nog bijna de helft een cursus, nu is dat nog maar een op de drie. Een afname van maar liefst 13\%-punt. De daling van de scholingdeelname van de 46-55 jarigen doet daar overigens nauwelijks voor onder met een afname van $12 \%$-punt. Bij de jongeren is de cursusdeelname daarentegen stabiel. De cursusdeelname neemt zowel onder vrouwen als mannen af. Mannen nemen wel nog steeds iets vaker aan cursussen deel dan vrouwen en besteden aan deze cursussen gemiddeld ook meer tijd.

Dit verschil is ook terug te zien in de cijfers over de cursusdeelname van parttimers versus die van voltijds werkenden. Parttimers, voor het merendeel vrouwen, nemen aanzienlijk minder deel aan cursussen. Parttimers volgen tussen 2000 en 2002 niet meer dan 9 uur cursus, terwijl fulltimers gemiddeld meer dan twee keer zoveel tijd, ruim 12 uur, aan cursussen besteedden. De veel geringere scholingsdeelname van parttimers lijkt een wetmatigheid te zijn, die zich ook in andere landen voordoet. ${ }^{29}$ Het kan ook eenvoudig verklaard worden door het lagere rendement van de scholing van parttimers. De werktijd waarin de investering in scholing rendeert is immers korter, waardoor het langer duurt voordat de investering is terugverdiend. Voor de Nederlandse economie, die zich in internationaal perspectief kenmerkt door een erg hoog percentage parttime werkenden impliceert dit dat het risico op verlies van werk door onvoldoende scholingsparticipatie voor relatief veel werkenden groot is.

Opvallend is ook de sterk afgenomen cursusdeelname van werknemers met een tijdelijk contract die géén uitzicht hebben op een vast dienstverband. Uit tabel 3.1 blijkt bijvoorbeeld dat werkenden met een tijdelijk contract zonder uitzicht op een vaste baan gemiddeld zo'n 7 uur minder deelnemen aan scholing dan werkenden met een tijdelijk contract die wel uitzicht hebben op een vast contract. Dit geeft

29. A. de Grip (2000), Van tweedekansonderwijs naar een leven lang leren, Universiteit Maastricht. 
duidelijk aan dat de training die werkenden volgen over het algemeen gericht is op de eigen functie of een in het vooruitzicht gestelde functie en bijvoorbeeld niet op externe mobiliteit. De scholingsdeelname is verder het hoogst onder autochtone werknemers, hoewel het verschil niet groot is, zo'n $7 \%$. Het verschil in trainingsdeelname tussen allochtonen en autochtonen neemt bovendien ten opzichte van de periode 1998-2000 iets af.

Tabel 3.1

Cursusdeelname 1998-2002

\begin{tabular}{|c|c|c|c|c|}
\hline Categorie werkenden & $\begin{array}{c}\text { 1998- } \\
200{ }^{*} \\
\%\end{array}$ & $\begin{array}{c}2000- \\
2002^{*} \\
\%\end{array}$ & $\begin{array}{c}2000-2002 \\
\text { Aantal } \\
\text { cursussen } \\
\text { per } \\
\text { werkende }^{* *}\end{array}$ & $\begin{array}{c}2000-2002 \\
\text { Uren cursus } \\
\text { per } \\
\text { werkende }\end{array}$ \\
\hline \multicolumn{5}{|l|}{ Bedrijfssector } \\
\hline Landbouw en visserij & & 35 & 0,63 & 7,7 \\
\hline Voeding & 43 & 57 & 0,90 & 17,4 \\
\hline Chemie & 59 & 35 & 0,64 & 11,1 \\
\hline Metalektro & 55 & 45 & 0,73 & 10,5 \\
\hline Overige industrie & 48 & 33 & 0,76 & 8,2 \\
\hline Energie & 62 & 61 & 1,44 & 9,0 \\
\hline Bouw & 56 & 51 & 0,81 & 8,5 \\
\hline Handel & 48 & 34 & 0,63 & 9,8 \\
\hline Transport en communicatie & 45 & 40 & 0,67 & 7,9 \\
\hline Bank- en verzekering & 66 & 56 & 1,21 & 17,4 \\
\hline Horeca en zakelijke dienstverlening & 50 & 40 & 0,83 & 10,3 \\
\hline Kwartaire diensten & 48 & 43 & 0,82 & 9,0 \\
\hline Overheid en onderwijs & 62 & 54 & 1,12 & 15,5 \\
\hline \multicolumn{5}{|l|}{ Leeftijd } \\
\hline $15-25$ jaar & 40 & 41 & 0,72 & 7,7 \\
\hline 26-35 jaar & 52 & 49 & 0,98 & 13,0 \\
\hline $36-45$ jaar & 56 & 47 & 0,92 & 11,5 \\
\hline 46-55 jaar & 52 & 40 & 0,74 & 10,1 \\
\hline 56-65 jaar & 45 & 32 & 0,54 & 6,0 \\
\hline \multicolumn{5}{|l|}{ Geslacht } \\
\hline Vrouwen & 41 & 48 & 0,76 & 9,9 \\
\hline Mannen & 46 & 54 & 0,91 & 11,4 \\
\hline \multicolumn{5}{|l|}{ Aard van het dienstverband/contract } \\
\hline Parttime contract $(\leq 32$ uur $\mathrm{p} / \mathrm{w})$ & 46 & 38 & 0,71 & 8,8 \\
\hline Fulltime contract $(>32$ uur $\mathrm{p} / \mathrm{w})$ & 56 & 50 & 0,98 & 12,4 \\
\hline Tijdelijk dienstverband & 37 & 25 & 0,35 & 4,9 \\
\hline Vast dienstverband & 55 & 46 & 0,89 & 11,2 \\
\hline \multicolumn{5}{|l|}{ Tijdelijk dienstverband, uitzicht op } \\
\hline vast & 40 & 45 & 0,83 & 12,1 \\
\hline \multicolumn{5}{|l|}{ Etniciteit } \\
\hline Autochtoon & 52 & 45 & 0,86 & 10,8 \\
\hline Allochtoon & 42 & 38 & 0,71 & 10,3 \\
\hline Totaal & 52 & 44 & 0,84 & 10,7 \\
\hline
\end{tabular}

Bron: Arbeidsaanbodsurvey (OSA)

$*$ Het betreft hier het percentage werkenden dat in de betreffende periode deelnam aan één of meerdere cursussen.

** = Het gaat hierbij om het gemiddelde over alle werkenden in de sector, d.w.z. inclusief de werkenden die geen cursus hebben gevolgd. 
Tabel 3.2 geeft een indruk van het soort cursussen dat in de verschillende bedrijfssectoren wordt gevolgd. In het algemeen zijn ICT cursussen en management en communicatiecursussen het populairst. Zo'n 10\% van de werkenden heeft in de periode 2000-2002 één of meer van deze cursussen gevolgd. ICT-trainingen zijn vooral in de energiesector en de sector overheid en onderwijs populair. Ongeveer 1 op de 5 werknemers in deze sectoren heeft in de periode 2000-2002 een cursus op dit gebied gevolgd. Voor de sector overheid en onderwijs geldt dat de hoge deelname aan cursussen op het gebied van ICT waarschijnlijk wordt ingegeven door het feit dat de vernieuwingen in ICT elkaar in een relatief hoog tempo opvolgen. Wat dat betreft is de deelname aan ICT-cursussen door werknemers in het bank- en verzekeringswezen maar bescheiden. Technologische vernieuwingen volgen elkaar immers in het bank- en verzekeringswezen het snelst op, terwijl in deze sector slechts één op de tien werknemers cursussen op ICT-gebied volgt. Werknemers in het bank- en verzekeringswezen volgen vooral management en communicatiecursussen, cursussen op het gebied van verzekeringen en commerciële vaardigheden en administratieve cursussen.

In de landbouwsector, waar de cursusdeelname over het algemeen beperkt is, volgt $16 \%$ van de werkenden een of meerdere vakspecifieke agrarische cursussen. Eenzelfde percentage volgde een cursus op het gebied van milieu, veiligheid en arbeidsomstandigheden. ${ }^{30}$ Dit soort cursussen is voor de werkenden in de landbouwsector van groot belang, omdat de fysieke belasting van het werk in de agrarische sector naar verhouding hoog is. Ook in de bouwsector en de metalektro - de twee sectoren waar de fysieke belasting nog hoger is dan in de landbouwsector (zie figuur 2.1) - worden er relatief veel cursussen op het gebied van milieu, veiligheid en arbeidsomstandigheden gevolgd. In de chemie gaat de aandacht naast de scholing op het gebied van milieu, veiligheid en arbeidsomstandigheden vooral uit naar (vakspecifieke) technische opleidingen. In de handel zijn deze technische opleidingen ook wat populairder dan in de meeste andere sectoren. Daarbij gaat het bijvoorbeeld om cursussen op het gebied van de autoreparatie.

In tabel 3.3 wordt aangegeven waarom werknemers een bepaalde cursus hebben gevolgd. De meeste scholing wordt door werkenden gevolgd om bij te blijven op hun vakgebied. Daarnaast wordt 30\% van de cursussen gevolgd, omdat het volgen van de opleiding verplicht is. Dit laatste geeft aan dat bijna één derde van de door werkenden gevolgde scholing wordt gevolgd zonder dat de werkende zelf duidelijk kan aangeven waarom hij of zij deze opleiding volgt. Dit duidt er op dat men waarschijnlijk weinig gemotiveerd is om de cursus te volgen. Ook wijst het er op dat werkgevers te vaak onvoldoende duidelijk maken waarom het voor hun werknemers belangrijk is om een bepaalde training te volgen.

30. Hiertoe behoren bijvoorbeeld ook de 'verplichte' bedrijfshulpverlenerscursussen (BHV). 


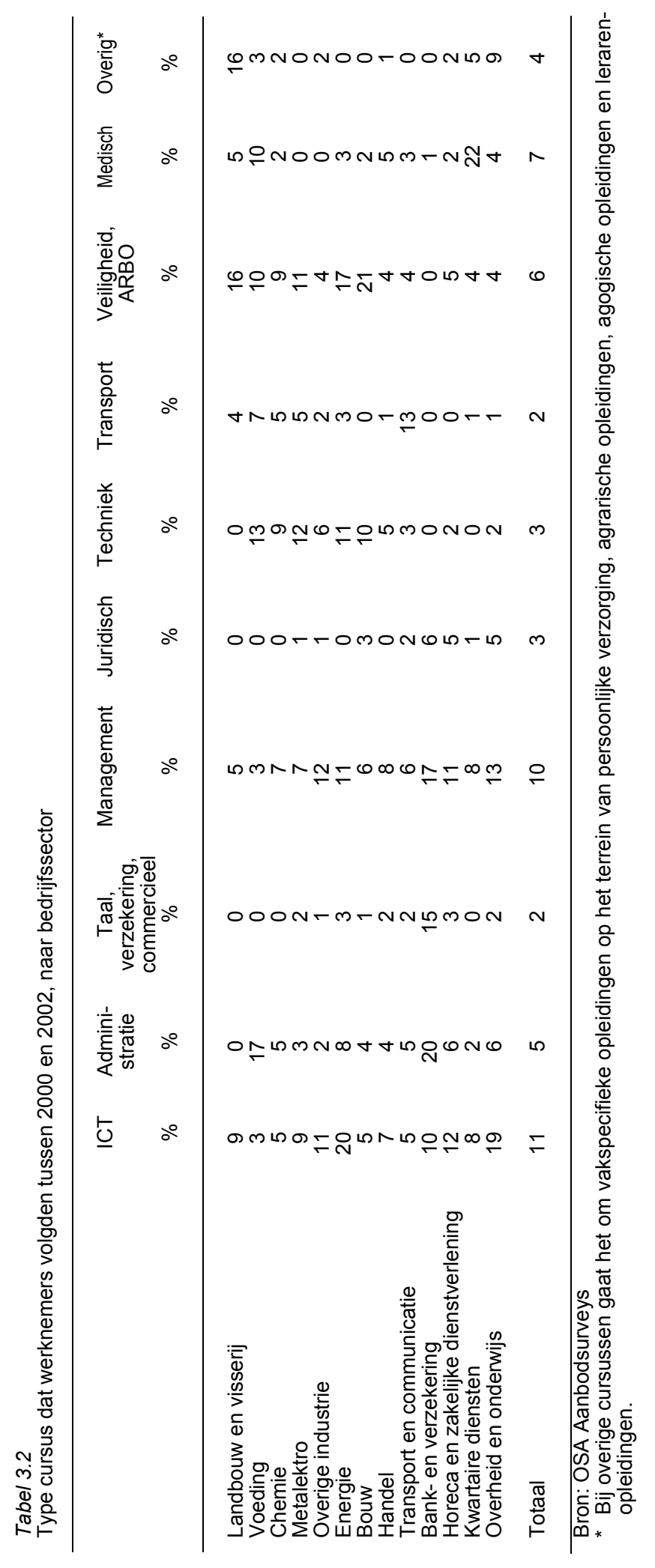


Tabel 3.3

Redenen om cursus te volgen, naar bedrijfssector, 2002

\begin{tabular}{|c|c|c|c|c|c|}
\hline & $\begin{array}{c}\text { Bijblijven } \\
\%\end{array}$ & $\begin{array}{c}\text { Promotie } \\
\%\end{array}$ & $\begin{array}{c}\text { Ander } \\
\text { werk } \\
\%\end{array}$ & $\begin{array}{c}\text { Verplicht } \\
\%\end{array}$ & $\begin{array}{c}\text { Andere } \\
\text { reden } \\
\%\end{array}$ \\
\hline \multicolumn{6}{|l|}{ Landbouw en visserij } \\
\hline $\begin{array}{l}\text { Voeding } \\
\text { Chemie }\end{array}$ & . & . & . & & \\
\hline $\begin{array}{l}\text { Metalektro } \\
\text { Overige industrie }\end{array}$ & 38 & 13 & 6 & 31 & 13 \\
\hline Energie & 43 & 0 & 29 & 14 & 14 \\
\hline Bouw & 22 & 22 & 13 & 39 & 4 \\
\hline Handel & 47 & 13 & 21 & 17 & 2 \\
\hline Transport en communicatie & 27 & 15 & 15 & 42 & 0 \\
\hline Bank-en verzekering & 30 & 17 & 3 & 37 & 13 \\
\hline $\begin{array}{l}\text { Horeca en zakelijke } \\
\text { dienstverlening }\end{array}$ & 43 & 14 & 15 & 24 & 5 \\
\hline Kwartaire diensten & 33 & 7 & 13 & 33 & 14 \\
\hline Overheid en onderwijs & 38 & 6 & 13 & 30 & 13 \\
\hline Totaal & 35 & 11 & 14 & 30 & 10 \\
\hline
\end{tabular}

Bron: OSA Aanbodsurveys

. Voor deze bedrijfssector zijn geen betrouwbare gegevens beschikbaar.

Slechts 1 op de 10 cursussen wordt gevolgd met het oog op promotie, terwijl $15 \%$ van de opleidingen wordt gevolgd omdat een werknemer ander werk wil gaan doen. De tabel laat grote verschillen zien tussen bedrijfssectoren. In de bouw en de transportsector worden cursussen vaker gevolgd omdat ze verplicht zijn. Kennelijk is er bij de werkenden in deze sectoren nog weinig oog voor het belang van de cursussen die ze volgen. In de handel worden cursussen daarentegen overwegend gevolgd omdat werknemers bij willen blijven op hun vakgebied. Dat geldt overigens ook voor de horeca en zakelijke dienstverlening en de energiesector. In deze sectoren wordt ruim $40 \%$ van de cursussen gevolgd om de competenties up-to-date te houden. In de energiesector is promotie bijna nooit een reden om een cursus te volgen. Dat geldt opvallend genoeg ook voor de sectoren overheid en onderwijs en kwartaire diensten, waar niet meer dan $7 \%$ van de cursussen wordt gevolgd om promotie te kunnen maken. In de bouw is het vergroten van de kansen op promotie daarentegen wel een belangrijke reden om een cursus te volgen. Opmerkelijk is ten slotte dat bijna één op de drie cursussen in de energiesector wordt gevolgd om ander werk te krijgen. Mogelijk is de krimpende werkgelegenheid van de afgelopen jaren in deze sector hiervan de oorzaak. ${ }^{31}$

Ook in de metalektro is bijblijven voor werknemers de belangrijkste reden om cursussen te volgen. Dat is overigens niet alleen voor werknemers het geval. Ook de werkgevers in de sector geven aan dat de deelname aan cursussen vooral wordt gestimuleerd om vaardigheden voor de huidige functie te verbeteren. ${ }^{32}$

31. De komende jaren wordt voor de energiesector echter weer een toename van de werkgelegenheid verwacht, Zie ROA (2003), De arbeidsmarkt naar opleiding en beroep tot 2008, ROA-R-2003/11, Maastricht.

32. Stichting Arbeidsmarkt en Opleiding in de Metalektro (2003) Nieuwsbrief Arbeidsmarktmonitor Metalektro, Leidschendam. 
Dat sectoroverstijgende scholing of mobiliteit nog nauwelijks aandacht krijgt blijkt ook uit onderzoek van den Boer en Hövels onder 1200 werknemers en 300 van hun werkgevers. Zij vinden een positief verband tussen de mogelijkheden cursussen te volgen, al dan niet op de werkplek, en de aanwezigheid van interne doorstroommogelijkheden. Dit verband is er niet tussen de mogelijkheden om cursussen te volgen en de aanwezigheid van externe doorstroommogelijkheden. ${ }^{33}$

Tabel 3.4 laat zien dat het merendeel van de cursussen onder werktijd wordt gevolgd. Slechts één op de vijf cursussen wordt gevolgd in de tijd van de werknemer. Tussen de bedrijfssectoren zijn er ook op dit punt weer grote verschillen. In de agrarische sector is het bijvoorbeeld veel vaker gebruikelijk om in de eigen tijd een cursus te volgen dan in andere sectoren. Meer dan de helft van de cursussen in de landbouwsector wordt in de eigen vrije tijd gevolgd. In de chemie en bouw ligt dat percentage weliswaar ruim 20\%-punt lager, maar nog altijd ruim boven het gemiddelde. In de chemie is daarnaast ook veel vaker sprake van cursussen die deels in eigen tijd en deels in werktijd worden gevolgd.

Tabel 3.4

Wanneer werd de cursus gevolgd, naar bedrijfssector, 2002

\begin{tabular}{lccc}
\hline & $\begin{array}{c}\text { Eigen vrije tijd } \\
\%\end{array}$ & $\begin{array}{c}\text { Werktijd } \\
\%\end{array}$ & $\begin{array}{c}\text { Combinatie } \\
\%\end{array}$ \\
& & & 0 \\
Landbouw en Visserij & 56 & 44 & 20 \\
Voeding & 20 & 30 & 31 \\
Chemie & 31 & 62 & 15 \\
Metalektro & 23 & 72 & 9 \\
Overige industrie & 19 & 77 & 10 \\
Energie & 13 & 55 & 2 \\
Bouw & 30 & 73 & 24 \\
Handel & 23 & 67 & 23 \\
Transport en communicatie & 10 & 49 & 23 \\
Bank- en verzekering & 28 & 61 & 14 \\
Horeca en zakelijke dienstverlening & 17 & 67 & 18 \\
Kwartaire diensten & 19 & 62 & 16 \\
Overheid en onderwijs & 19 & 63 & \\
Totaal & & & \\
\hline
\end{tabular}

Bron: OSA Aanbodsurveys

Vooral in de transportsector en de energiesector is het veel minder gebruikelijk dat werkenden in hun vrije tijd bepaalde cursussen volgen. Ook in de handel en overige industrie wordt veruit het grootste deel van de cursussen geheel in werktijd gevolgd. In de handel zelfs bijna $80 \%$. Vooral in de chemie en de agrarische sector is dat veel minder het geval.

Opvallend is overigens wel dat, in vergelijking met de scholingsdeelname in de periode 1998-2000, cursussen aanzienlijk vaker in werktijd worden gevolgd en veel

33. P. den Boer en B. Hövels (2002), Werken en leren in arbeidsorganisaties, OSA-publicatie 187, Tilburg. 
minder vaak in de eigen tijd. Later in dit hoofdstuk (tabel 3.6) zal ook blijken dat werknemers minder zijn gaan deelnemen aan kortere opleidingstrajecten en wat meer aan langere trajecten. Dit zou een verklaring kunnen zijn voor het feit dat de werkgever ook vaker de indirecte kosten van cursussen, in termen van de werktijd die een werknemer niet productief kan worden ingezet, voor zijn rekening neemt. De kosten die met langere opleidingstrajecten gemoeid zijn, zijn immers sowieso al vaker voor rekening van de werkgever. Bovendien zijn de scholingskosten én de verletkosten subsidiabel via de O\&O-fondsen als zij gebruik maken van ESFsubsidies).

Tabel 3.5 laat zien dat ook de directe cursuskosten voornamelijk voor rekening van de werkgever zijn. Ruim $85 \%$ van de cursussen wordt geheel door de werkgever betaald. $10 \%$ wordt door de werknemer zelf bekostigd. Het Centrum voor Werk en Inkomen (CWI) bekostigt niet meer dan 1\% van de gevolgde cursussen. Het CWI richt zich echter ook vooral op werklozen en niet op werkenden.

Tabel 3.5

Bekostiging van de door werknemers gevolgde cursussen, naar bedrijfssector, 2002

\begin{tabular}{lccccc} 
& $\begin{array}{c}\text { Werknemer } \\
\text { zelf } \\
\%\end{array}$ & Werkgever & Combinatie & CWI & Anders \\
& & $\%$ & $\%$ & $\%$ & $\%$ \\
\hline Landbouw en Visserij & 44 & 56 & 0 & 0 & 0 \\
Voeding & 7 & 81 & 0 & 0 & 11 \\
Chemie & 4 & 93 & 0 & 4 & 0 \\
Metalektro & 5 & 94 & 0 & 0 & 2 \\
Overige industrie & 5 & 87 & 0 & 0 & 8 \\
Energie & 4 & 96 & 0 & 0 & 0 \\
Bouw & 7 & 92 & 0 & 0 & 1 \\
Handel & 10 & 86 & 2 & 2 & 1 \\
Transport en communicatie & 12 & 87 & 1 & 0 & 0 \\
Bank- en verzekering & 7 & 91 & 1 & 0 & 1 \\
Horeca en zakelijke & 15 & 81 & 1 & 1 & 2 \\
dienstverlening & 13 & 81 & 4 & 1 & 2 \\
Kwartaire diensten & 6 & 91 & 1 & 1 & 1 \\
Overheid en onderwijs & 10 & 86 & 1 & 1 & 2 \\
Totaal & & & & & \\
\hline
\end{tabular}

Bron: OSA Aanbodsurveys

Ook voor wat betreft de bekostiging van de directe kosten van scholing zijn er grote verschillen zichtbaar tussen de bedrijfssectoren. Opvallend is vooral dat in de agrarische sector de werkenden vaak de kosten van trainingen helemaal zelf betalen. Waarschijnlijk gaat het hierbij echter in veel gevallen om zelfstandigen die hun eigen cursussen betalen. In de horeca en zakelijke dienstverlening en de kwartaire diensten komen de kosten van cursussen ook iets vaker op de schouders van de werkenden zelf te liggen. Vooral in de energie, de metalektro en de chemie betaalt de werkgever vrijwel altijd de kosten van scholing. Voor de metalektro en de chemie zou dat versterkt kunnen worden door de stimulerende rol die O\&O en A\&O fondsen in deze sectoren vervullen. 
Het komt nog maar zeer zelden voor dat de opleidingskosten worden gedeeld door de werkgever en de betrokken werknemer. Niet meer dan $1 \%$ van de cursussen wordt gedeeltelijk door werkgever en gedeeltelijk door werknemer bekostigd. Dat is opvallend weinig, zeker gezien het feit dat in 2000 nog iets meer dan $20 \%$ van de cursussen op die manier werd gefinancierd.

\subsection{Risicogroepen op de Nederlandse arbeidsmarkt}

In tabel 3.6 wordt een overzicht gegeven van het gemiddelde percentage werkenden dat in de verschillende bedrijfssectoren in de jaren 2001 en 2002 een opleiding volgde. Ter vergelijking is ook het percentage werkenden weergegeven dat in 2000 een opleiding volgde. In de tabel wordt een onderscheid gemaakt tussen 'korte' opleidingstrajecten van minder dan 6 maanden en lange opleidingstrajecten die 6 maanden of langer duren. Dit onderscheid geeft een indicatie van de opleidingsinspanning, al kan het natuurlijk soms zo zijn dat een korte opleiding meer trainingsuren impliceert dan een langer durend trainingstraject.

Uit tabel 3.6 blijkt dat vooral in het bank- en verzekeringswezen de deelname aan zowel korte als langere scholingstrajecten relatief hoog is. Ruim $10 \%$ van de werknemers in het bank- en verzekeringswezen volgt jaarlijks een korte opleiding, terwijl zo'n $16 \%$ een langere opleiding volgt. Vooral bij de korte trajecten springt het banken verzekeringswezen er uit. De energiesector en de sector overheid en onderwijs, waar $6 \%$ van de werknemers een korte opleiding volgt, volgen op enige afstand.

Tabel 3.6

Scholingsdeelname per bedrijfssector, 2000 en gemiddelde 2001/2002

\begin{tabular}{|c|c|c|c|c|}
\hline & \multicolumn{2}{|c|}{$\begin{array}{l}\text { Opleiding korter dan } \\
6 \text { maanden }\end{array}$} & \multicolumn{2}{|c|}{$\begin{array}{c}\text { Opleiding van } 6 \text { maanden } \\
\text { of langer }\end{array}$} \\
\hline & $\begin{array}{r}2000 \\
\%\end{array}$ & $\begin{array}{c}2001-2002 \\
\%\end{array}$ & $\begin{array}{c}2000 \\
\%\end{array}$ & $\begin{array}{c}2001-2002 \\
\%\end{array}$ \\
\hline Landbouw en visserij & 3 & 2 & 13 & 11 \\
\hline Voeding & 4 & 3 & 11 & 12 \\
\hline Chemie & 5 & 4 & 12 & 11 \\
\hline Metalektro & 5 & 4 & 9 & 9 \\
\hline Overige industrie & 3 & 3 & 7 & 7 \\
\hline Energie & 5 & 6 & 9 & 10 \\
\hline Bouw & 4 & 3 & 10 & 11 \\
\hline Handel & 4 & 3 & 15 & 16 \\
\hline Transport en communicatie & 6 & 4 & 9 & 9 \\
\hline Bank- en verzekering & 11 & 10 & 17 & 16 \\
\hline Horeca en zakelijke dienstverlening & 6 & 4 & 16 & 17 \\
\hline Kwartaire diensten & 4 & 4 & 14 & 14 \\
\hline Overheid en onderwijs & 7 & 6 & 13 & 14 \\
\hline Totaal & 5 & 4 & 13 & 14 \\
\hline
\end{tabular}

Bron: EBB (CBS)

De deelname aan korte opleidingen ligt het laagst in de landbouwsector, gevolgd door de handel, bouw, voedingsindustrie en overige industrie. De deelname aan 
langere scholingstrajecten is daarentegen vooral laag in de overige industrie, gevolgd door de transportsector en de metalektro.

Opmerkelijk is dat in vrijwel alle sectoren de deelname aan korte opleidingen sterk is gedaald. De gemiddelde afname bedraagt ongeveer 1 à $2 \%$-punt. De daling van de deelname aan korte trajecten is het grootst in de sector horeca en zakelijke dienstverlening en de transportsector. In 2000 nam nog ruim $6 \%$ van de werknemers in deze sectoren aan kortere opleidingen deel, in 2001 en 2002 was dat gemiddeld nog maar $4 \%$. De energiesector vormt op dit punt echter een positieve uitzondering. In deze sector is sprake van een lichte stijging van de deelname aan korte opleidingen.

De deelname aan langere scholingstrajecten is daarentegen licht gestegen. Dat geldt vooral voor de sector horeca en zakelijke dienstverlening, waar sprake lijkt te zijn van een verschuiving van de participatie in korte scholingstrajecten naar de deelname aan langere opleidingstrajecten. Ook in de voedingsindustrie, de energiesector en de sector overheid en onderwijs is er sprake van een stijgende deelname aan langere opleidingstrajecten. In de voedingsindustrie en de sector overheid en onderwijs gaat deze stijgende deelname aan langere opleidingstrajecten eveneens gepaard met een sterk dalende deelname aan kortere opleidingen.

\section{Beperkte scholingsdeelname: Risicoberoepen}

Om te komen tot een overzicht van de belangrijkste risicoberoepen in termen van een geringe scholingsparticipatie, is allereerst gekeken naar de scholingsdeelname in totaal, dat wil zeggen de deelname aan zowel korte als langer durende opleidingen. Op grond van hun geringe deelname aan zowel korte als lange scholingstrajecten vormen de grafische vakkrachten in de sector overige industrie (waartoe ook de grafische industrie wordt gerekend) en de chauffeurs die werkzaam zijn in de handel de belangrijkste risicoberoepen.

De geringe deelname aan langer lopende opleidingen vormt in de sector overige industrie behalve voor de grafisch vakkrachten vooral een risico voor het grafisch productiepersoneel en de bouwvakkers die in deze sector werkzaam zijn. Naast de chauffeurs die werkzaam zijn in de handel vormt ook de veel grotere groep chauffeurs in de transportsector een belangrijke aandachtsgroep. Ten slotte is in de bouw de deelname aan langere scholingstrajecten opvallend laag onder de weg- en waterbouwkundige vakkrachten.

\section{Beperkte scholingsdeelname: Risico-opleidingen}

Er zijn geen groepen werkenden met een bepaalde opleidingsachtergrond waarvoor geldt dat zij zeer weinig deelnemen aan zowel korte als lange opleidingstrajecten. Dit geldt opmerkelijk genoeg ook voor de werkenden die (nog) niet beschikken over een startkwalificatie voor de arbeidsmarkt. De deelname aan langere opleidingstrajecten is echter wel vooral laag onder de werknemers met alleen basisonderwijs in de sector overige industrie en de transportsector. Maar ook werknemers met een MBO 
diploma grafische techniek of economie in de sector overige industrie nemen relatief weinig aan langere opleidingen deel.

Ook de werknemers in de transportsector met een VMBO of MBO opleiding transport en logistiek en de werknemers met een MBO opleiding natuur en techniek in de landbouwsector volgen niet vaak een langere opleiding. Opvallend is ten slotte de geringe deelname aan langere opleidingstrajecten onder werkenden met een MBO opleiding dokters-, tandarts-, en dierenartsassistent in de kwartaire dienstensector.

\subsection{De rol van opleidingsfondsen}

Onderzoek van de Stichting van de Arbeid laat zien dat vrijwel alle CAO's in 2002 één of meerdere afspraken op het gebied van scholing en opleiding bevatten. Die afspraken hebben betrekking op $97 \%$ van alle werknemers die onder een CAO vallen. ${ }^{34}$ Reeds vanaf de jaren tachtig wordt in steeds meer CAO's de afspraak gemaakt dat de bedrijven een bepaald percentage van de totale loonsom afdragen voor de scholing van de werkenden in de sector. Meestal gaat het hierbij om een percentage tussen de 0,5 en de $1,5 \%$ van de loonsom.

Voor de besteding van deze middelen hebben de meeste bedrijfstakken gekozen voor de oprichting van een centraal fonds. Meestal aangeduid als een Opleidings- en ontwikkelingsfonds (O\&O fonds) of een Arbeidsmarkt- en opleidingsfonds (A\&O fonds). Deze fondsen dragen de zorg voor het inzetten van de scholingsgelden die zij van de bedrijven in de bedrijfstak krijgen.

De keuze voor het oprichten van centrale fondsen berust op een aantal belangrijke overwegingen. Allereerst gaat er een stimulerende werking uit van de bij CAO verplichte loonsomheffing. Werkgevers betalen de heffing en kunnen deze gelden vervolgens door middel van subsidies voor hun scholingsactiviteiten weer terugverdienen. Dit stimuleert bedrijven om zelf ook te investeren in de scholing van hun personeel. Bovendien worden werkgevers gestimuleerd goed na te denken over de precieze behoefte aan bij- en omscholing. Middelen van de O\&O fondsen worden immers uitsluitend besteed op basis van aanvragen, die aan bepaalde criteria voldoen. Fondsvorming op basis van de loonsomheffingen zou de scholingsparticipatie van werknemers ook minder conjunctuurgevoelig kunnen maken. De verplichte afdracht is immers gekoppeld aan de loonsom. In de praktijk is dit echter niet zonder meer het geval. Zo wordt telkens in de CAO's afgesproken welk percentage van de loonsom aan het opleidingsfonds wordt afgedragen. Met name in economisch minder gunstige tijden staat de afdracht aan de scholingsfondsen sterk onder druk. In enkele gevallen wordt de loonsomheffing zelfs tijdelijk stopgezet.

"De loonsomheffing en dus ook het budget van de fondsen kan sterk fluctueren, omdat bij de CAO onderhandelingen telkens nieuwe

34. Stichting van de Arbeid (2002), Inventarisatie naar de aard en omvang van scholingsinspanningen van sociale partners in bedrijfstakken en ondernemingen, Den Haag. 
afspraken over de loonsomheffing worden gemaakt. Gaat het economisch wat minder dan vormt de loonsomheffing een interessant onderhandelingspunt voor de sociale partners. Het afgelopen jaar is er bijvoorbeeld geen heffing geweest, terwijl er enkele jaren geleden nog $0,8 \%$ van de loonsom werd geheven". ${ }^{35}$

Een belangrijk nadeel van het systeem van loonsomheffing is dat er in sectoren waar relatief veel lager opgeleiden werkzaam zijn (met uiteraard een naar verhouding lagere loonsom) minder middelen naar de fondsen vloeien dan in sectoren, waar veel hoogopgeleiden werken. Een ander probleempunt is dat in de meeste sectoren diverse vormen van informele scholing en training (ervaringsleren en bijvoorbeeld leren op de werkplek) niet voor bekostiging via het O\&O fonds in aanmerking komen. Deze vaak belangrijke informele scholing wordt daardoor in feite ontmoedigd. Vooral kleine bedrijven, waar veel informele scholing plaatsvindt, worden hierdoor gedupeerd. Met de introductie en het subsidiabel maken van EVC-trajecten (Erkenning van Verworven Competenties) wordt echter ook informele scholing steeds vaker bekostigd via de O\&O fondsen.

"We werken nu aan een tweede experiment met EVC-trajecten. Voor ondernemingen zijn die trajecten interessant omdat zij een beter beeld hebben van wat er aan kennis en kunde in huis is. Ondernemingen kunnen zich daardoor ook beter profileren. Voor werknemers is EVC interessant omdat zij hun competenties nu eens bevestigd zien en het hun externe arbeidsmarktpositie verbetert. Eigenlijk is voor iedereen in de sector EVC van groot belang."

Tot 1999 hadden de opleidingsfondsen vrijwel uitsluitend oog voor functiegerichte scholing. Algemene scholing, het vergroten van de employability van werknemers en het bevorderen van mobiliteit behoorde niet of nauwelijks tot de doelstellingen van O\&O fondsen. ${ }^{36}$ Sinds 2000 is de doelstelling van veel O\&O fondsen echter verbreed en inmiddels beperkt zo'n $40 \%$ van de O\&O fondsen zich niet meer louter tot subsidiëring van scholing voor de eigen bedrijfstak. Deze fondsen beogen ook de bekostiging van scholing die sectoroverstijgend is. ${ }^{37}$ Het beleid op dit punt staat echter nog in de kinderschoenen. Zoals reeds eerder werd aangegeven, wordt de scholing die, in de gevallen waar dat wenselijk is, de sectoroverstijgende mobiliteit van werknemers zou kunnen bevorderen daardoor nog steeds onvoldoende gestimuleerd.

"leder fonds zit in de eigen zuil, de eigen branche en het is wel leuk om ervaringen uit te wisselen, maar echt samenwerken aan scholingseleid

35. De citaten in deze paragraaf zijn afkomstig uit gesprekken met sleutelpersonen van enkele O\&O fondsen.

36. H.J. van Driel, E. van Straten, C.J. van Uitert, J.P. Vendrig en Y. van der Burgh (1999), Activiteiten van O\&O fondsen: Dragen O\&O fondsen bij aan employability? Werkdocument nr. 133, Ministerie van Sociale Zaken en Werkgelegenheid, (2002), Den Haag.

37. J.M. Waterreus, (2002), O\&O fondsen op herhaling, Max Goote Kenniscentrum, Amsterdam. 
of subsidie-aanvragen is heel wat anders en dat gebeurt maar zelden. We zien de grenzen van de branche zo nu en dan overigens wel vervagen. Groothandelsbedrijven die detaillist worden, detaillisten die horeca-activiteiten ontwikkelen. Maar dat maakt het voeren van scholingsbeleid er niet eenvoudiger op. Het is steeds meer de vraag waar een opleidingsvraag en dus ook een subsidie-aanvraag thuishoort, bij ons of bij een ander fonds".

"Ondanks de vele drempels (bijvoorbeeld verschillen in CAO's voor wat betreft pensioenregelingen) is er wel degelijk interesse in samenwerking en intersectoraal werken en opleiden. Zeker ook vanuit de bedrijven."

\section{Opleidingsfondsen}

Er zijn in Nederland zo'n 100 opleidingsfondsen, die hun middelen uit loonsomheffingen verkrijgen. Daarnaast zijn er zo'n 20 brancheoverstijgende opleidingsfondsen die de participatie in scholing in het algemeen proberen te stimuleren, bijvoorbeeld door middel van cofinanciering van scholingsprojecten. Deze 20 opleidingsfondsen verkrijgen hun middelen niet uit loonsomheffingen maar uit nationale en Europese subsidies.

In tabel 3.7 wordt aangegeven in welke bedrijfssectoren O\&O fondsen actief zijn. Vooral in de handel zijn er veel O\&O fondsen actief: maar liefst 27. Dat heeft alles te maken met de structuur van deze sector. Veel detailhandelsbranches (schoenmakers, bakkers, slagers) hebben een eigen, relatief klein fonds.

"Het is onmogelijk te spreken over dé sector detailhandel. Met dé sector worden zo'n 70 sterk van elkaar verschillende branches bedoeld. De diversiteit van de sector weerspiegelt zich sterk in het sectoraal scholingsbeleid".

Daarentegen zijn er in de chemie, de energiesector en het bank- en verzekeringswezen slechts één of twee fondsen voor de gehele sector. De sectoren met één of twee O\&O fondsen worden vaak gedomineerd door enkele grote bedrijven. De werknemers van deze bedrijven hebben doorgaans vergelijkbaar werk, zodat de scholingsbehoefte van deze bedrijven veel overeenstemming vertoont.

$\mathrm{Er}$ is een opvallend verschil in het bereik van de fondsen. Het O\&O fonds voor de chemie bereikt met 200.000 álle werkenden in die sector en de twee O\&O fondsen in de energiesector hebben een bereik van ruim $70 \%$ van het totaal aantal werkenden. Het fonds dat onder het bank- en verzekeringswezen valt is het fonds voor de zorgverzekeraars. Dit fonds bereikt in totaal 7.000 werkenden. Dat is nog geen $3 \%$ van het totaal aantal werkenden in de sector (zo'n 275.500). Dat niettemin 90\% van de bedrijven in de sector een bijdrage levert aan externe scholingsfondsen is eenvoudig te verklaren. Vrijwel alle banken en verzekeringsmaatschappijen leveren elk jaar op basis van onderlinge afspraken naar rato een bijdrage aan de 
instandhouding van het Nederlands Instituut voor het Bank-, Verzekerings- en Effectenbedrijf (NIBE-SVV), dat in feite het centrale opleidingsinstituut is voor de sector bank- en verzekeringswezen. Er wordt dus wel elk jaar op basis van onderlinge afspraken bijgedragen aan een extern opleidings'fonds', maar het betreft hier geen $\mathrm{O} \& \mathrm{O}$ fonds, maar een opleidingsinstituut.

Tabel 3.7

O\&O fondsen: aantal, bereik, bijdrage bedrijven en reserve per werkende, naar bedrijfssector, 1999

\begin{tabular}{|c|c|c|c|c|}
\hline Bedrijfssector & $\begin{array}{c}\text { Aantal } \\
\text { fondsen }\end{array}$ & $\begin{array}{l}\text { Bereik: } \\
\text { Aantal } \\
\text { werken- } \\
\text { den* }^{*}\end{array}$ & $\begin{array}{c}\text { Bedrijven die } \\
\text { bijdragen }^{* *} \\
\%\end{array}$ & $\begin{array}{c}\text { Reserve: } \\
€ \text { per } \\
\text { werkende*** }\end{array}$ \\
\hline $\begin{array}{l}\text { Landbouw en visserij } \\
\text { Voeding } \\
\text { Chemie } \\
\text { Metalektro } \\
\text { Overige industrie } \\
\text { Energie } \\
\text { Bouw } \\
\text { Handel } \\
\text { Transport en communicatie } \\
\text { Bank- en verzekering } \\
\text { Horeca en zakelijke dienstverlening } \\
\text { Kwartaire diensten } \\
\text { Overheid en onderwijs }\end{array}$ & $\begin{array}{r}4 \\
10 \\
1 \\
12 \\
17 \\
2 \\
9 \\
27 \\
7 \\
1 \\
11 \\
10 \\
5\end{array}$ & $\begin{array}{r}302.400 \\
219.400 \\
200.000 \\
402.100 \\
222.000 \\
38.100 \\
447.400 \\
1.459 .200 \\
199.900 \\
7.000 \\
1.616 .000 \\
919.900 \\
492.000\end{array}$ & $\begin{array}{l}47 \\
68 \\
60 \\
64 \\
64 \\
65 \\
36 \\
47 \\
90 \\
40 \\
32 \\
39\end{array}$ & $\begin{array}{r}45 \\
48 \\
2 \\
182 \\
172 \\
410 \\
16 \\
76 \\
24 \\
192 \\
7\end{array}$ \\
\hline Totaal & 116 & 6.525 .400 & 43 & 107 \\
\hline
\end{tabular}

Bron: Waterreus, 2002; bewerking ROA Werknemers kunnen soms onder meerdere fondsen binnen hun sector ressorteren. Het totale bereik bevat daardoor dubbeltelingen.

** Bron: OSA Vraagsurvey 2001. Mogelijk is hier overigens sprake van een onderschatting van het percentage bedrijven dat bijdraagt aan een scholingsfonds, omdat alleen gevraagd is naar de bijdrage aan externe scholingsfondsen. Grote bedrijven met een eigen ondernemings-CAO maken hierin meestal wel afspraken over hun scholingsinspanningen, maar in dat geval is geen sprake van een extern scholingsfonds.

*** Alleen fondsen waarvan het bereik én de reserves bekend zijn, zijn meegerekend. In totaal gaat het daarbij om 51 van de 116 fondsen.

Ongeveer $43 \%$ van alle bedrijven in Nederland betaalt een bijdrage aan externe opleidingsfondsen. Dit percentage zal in werkelijkheid echter hoger uitvallen, omdat een aantal grotere ondernemingen wel een bijdrage levert aan eigen scholingsfondsen, die zij niet als extern beschouwen. In de sectoren kwartaire diensten, overheid en onderwijs en handel draagt slechts één van de drie organisaties bij aan een extern opleidingsfonds.

De O\&O fondsen hebben over het algemeen aardig wat middelen tot hun beschikking. De Arbeidsinspectie onderzocht in 199920 grote CAO-O\&O-fondsen, die minimaal op 5000 werknemers betrekking hadden. Uit het onderzoek blijkt dat in deze 20 fondsen in totaal ruim 300 miljoen euro omging. Het jaar 1999 werd door de fondsen gezamenlijk overigens wel afgesloten met een negatief saldo van ruim 7,5 
miljoen euro. De totale reserve van de 20 fondsen bedroeg aan het begin van 2000 echter nog altijd bijna 550 miljoen euro. ${ }^{38}$

In de laatste kolom van tabel 3.7 is te zien over hoeveel reservemiddelen de O\&O fondsen in de verschillende sectoren in 1999 beschikten. Het O\&O fonds in de chemie heeft per werkende de minste reserves, slechts $€ 2,-$. Dat betekent dat het O\&O fonds in deze sector de middelen die zij krijgt vrijwel direct geheel spendeert en er dus niet voor kiest om middelen te reserveren, om in economisch mindere tijden te zorgen voor een buffer en voor het op peil houden van de scholingsparticipatie van het personeel. De O\&O fondsen in de bouw hebben daarentegen gemiddeld per werkende ruim $€ 410$,- aan reserves. Op het eerste gezicht biedt een dusdanig ruime reserve natuurlijk een spectrum aan mogelijkheden voor anticyclisch scholingsbeleid. Anderzijds rijst de vraag of de bedrijven in de sector wel optimaal gebruik maken van de mogelijkheden die de fondsen hen bieden. Deze laatste vraag is met name van belang omdat één van de argumenten om te kiezen voor het systeem van O\&O fondsen was dat in principe álle werkgevers gebruik zouden gaan maken van de O\&O fondsen, omdat zij daar door de verplichte afdracht ook voor betalen. Net als in de bouwsector hebben ook de metalektro, de overige industrie en de kwartaire dienstensector een relatief ruime reserve per werkende, die goede mogelijkheden biedt voor het op peil houden van de scholingsactiviteiten in de sector in een periode van laagconjunctuur.

\section{Herkomst van middelen}

Tabel 3.8 laat zien waar de middelen van O\&O fondsen vandaan komen. De belangrijkste bron van inkomsten voor de O\&O fondsen zijn de verplichte werkgeverspremies. Daarnaast vallen ook de incidentele bijdragen van werkgevers (schenkingen en eventuele extra bijdragen in de kosten van het opleidingsfonds) onder deze noemer. Inkomsten uit ESF subsidies vormden slechts $2 \%$ van de totale inkomsten.

Tabel 3.8

Herkomst van de middelen van O\&O fondsen, 1999

\begin{tabular}{lr}
\hline Bron van inkomsten & $\%$ \\
\hline Verplichte bijdrage van bedrijven & 87 \\
Subsidie ESF (oude regeling) & 2 \\
Subsidie Overheid & 1 \\
Subsidie overig & 1 \\
Rente & 6 \\
Overige baten & 3
\end{tabular}

Bron: Sociale Fondsen Financieel Bezien, Arbeidsinspectie 2001

38. W. Smits (2001), Sociale Fondsen Financieel bezien, Arbeidsinspectie: Den Haag en W. Smit en C. Klaassen (2004), Sociale Fondsen 2002: Baten, lasten, reserves en doelstellingen tegen het licht, Arbeidsinspectie. 


\section{Besteding van middelen}

Tabel 3.9 laat zien dat ongeveer één op de drie bedrijven en instellingen in Nederland cursussen mede heeft gefinancierd met subsidies van de scholingsfondsen. Daarbij gaat het vooral om grotere bedrijven, want het percentage werkenden dat werkzaam is in bedrijven waar subsidies zijn ontvangen bedraagt ruim $70 \%$. In de metalektro en bouw wordt door de bedrijven in de sector veel gebruik gemaakt van de beschikbare O\&O subsidies. In de metalektro zijn vrijwel alle werkenden werkzaam in bedrijven waar cursussen worden gevolgd die gefinancierd zijn met behulp van $O \& O$ gelden. ${ }^{39}$

Tabel 3.9

Subsidies voor cursussen ontvangen van O\&O fondsen, naar bedrijfssector, 2001

\begin{tabular}{lcc}
\hline Bedrijfssector & $\begin{array}{c}\text { Bedrijven } \\
\%\end{array}$ & $\begin{array}{c}\text { Werkenden } \\
\%\end{array}$ \\
\hline Landbouw en visserij & 30 & 31 \\
Voeding &. &. \\
Chemie & 85 & 99 \\
Metalektro &. &. \\
Overige industrie & 55 & 87 \\
Energie & 55 & 31 \\
Hauwdel & 24 & 41 \\
Transport en communicatie & 11 & 33 \\
Bank- en verzekering & 26 & 72 \\
Horeca en zakelijke dienstverlening & 15 & 79 \\
Kwartaire diensten & 33 & 72 \\
Total & 32 &.
\end{tabular}

Bron: OSA Vraagsurvey

. = Voor deze bedrijfssector zijn geen betrouwbare gegevens beschikbaar.

In de landbouw, de handel en de horeca en zakelijke dienstverlening maken werkgevers nog maar beperkt gebruik van de O\&O fondsen. Ongeveer een kwart van de bedrijven in deze sector heeft van een O\&O fonds middelen ontvangen om scholing mee te bekostigen. Daarmee wordt niet meer dan één derde van de werknemers in deze sectoren bereikt.

Tabel 3.10 maakt duidelijk dat in 1999 43\% van de scholingssubsidies van de O\&O fondsen aan bijscholing werd besteed. De meeste scholing is dus gericht op het op peil houden van de competenties die werkenden nodig hebben om goed te kunnen functioneren in hun huidige baan, of op het verwerven van competenties die hen in staat stellen door te groeien naar een hogere functie. Op deze wijze wordt dus een substantiële bijdrage geleverd aan het verminderen van de risico's op verlies van werk vanwege functie-inhoudelijke competentieveroudering in de sectoren waar de

39. Of het bereik daadwerkelijk zo groot is hangt uiteraard vooral af van het beleid van de fondsen en bedrijven zelf. Richten zij zich bijvoorbeeld uitsluitend op de middelbaar opgeleiden dan is het percentage werkenden dat feitelijk gebruik kan maken van de verkregen subsidies uiteraard lager. 
O\&O fondsen actief zijn. Daarnaast wordt $12 \%$ van de scholingssubsidies uitgegeven aan het stimuleren van de deelname aan de beroepsbegeleidende leerweg (BBL) en $10 \%$ aan voorlichting.

Tabel 3.10

Verdeling uitgekeerde fondssubsidies over de verschillende doelen, doelgroepen en naar sectorspecificiteit, 1999

$\%$

Doel

Bijscholing

Beroepsbegeleidende Leerweg (voorheen: leerlingwezen)

Voorlichting

Scholing van werkzoekenden

Kinderopvang

Onderzoek

Werkgelegenheidsprojecten

ARBO zorg

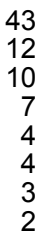

Doelgroep

Werkenden zonder 'startkwalificatie'*

Laaggeschoolden

Ouderen

Vrouwen

Allochtonen

Werkzoekenden

Geen doelgroepenbeleid

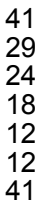

Sectorspecifiek/ bovensectoraal

Uitsluitend of vooral sectorspecifieke scholing

Uitsluitend of vooral bovensectorale scholing

Gelijkmatige verdeling sectorspecifieke/ bovensectorale scholing

Bron: Waterreus (2002)

* Gevraagd is of een fonds investeert in activiteiten voor mensen zonder startkwalificatie. Daarbij wordt niet precies aangegeven wat onder een 'startkwalificatie' wordt verstaan.

Slechts $2 \%$ van de O\&O subsidies wordt aan ARBO zorg besteed. Dat lijkt weinig, gezien de in hoofdstuk 2 beschreven risico's op verlies van werk vanwege belastende arbeidsomstandigheden. Het gaat hier echter om een gemiddelde over alle bedrijfssectoren, terwijl er op dit punt sprake is van grote verschillen tussen de diverse bedrijfssectoren. In de bouwsector - een sector waar de fysieke belasting van veel werkenden hoog is, wordt bijvoorbeeld meer dan de helft van de door de Stichting Scholingsfonds voor het Bouwbedrijf (SFB) in 2002 gesubsidieerde cursusdagen besteed aan scholing op het terrein van Arbo, veiligheid en gezondheid. ${ }^{40}$ Het SFB levert daarmee een duidelijke bijdrage aan het verminderen van de risico's op competentieveroudering vanwege belastende arbeidsomstandigheden.

Geconcludeerd kan worden dat in de meeste sectoren, de bestaande risico's op verlies van werk vanwege competentieveroudering in belangrijke mate richtinggevend zijn voor de besteding van de middelen van de O\&O fondsen. Hierbij

40. Scholingsfonds voor het bouwbedrijf (2003), Op koers, Jaarverslag 2002. 
ligt er wel een duidelijk accent op het voorkomen van verlies van werk vanwege functie-inhoudelijke competentieveroudering. Met uitzondering van de bouwsector is er relatief weinig aandacht voor scholing gericht op het verminderen van de risico's op competentieveroudering vanwege belastende arbeidsomstandigheden.

"Belastende arbeidsomstandigheden vormen een onderbelicht gebied binnen het opleidingsfonds. Structureel beleid gericht op arbeidsomstandigheden wordt in CAO verband beschouwd als een onderdeel van het Hoofdstuk 'Arbeidsvoorwaarden', dat elders uitonderhandeld wordt tussen werkgevers en vakverenigingen. De speelruimte van het opleidingsfonds is in dit opzicht beperkt, omdat de sociale partners vooral bepalen wat er gebeurt."

"De scholingsvraag is eigenlijk zo divers als de sector detailhandel zelf. Recent uitgevoerd onderzoek naar de scholingsbehoefte in de sector laat echter wel een aantal trends zien. Zo is er op het moment vooral aandacht voor scholing gericht op preventie van winkeldiefstal, verkooptraining, assortimentskennis en ICT. Het gaat hierbij vooral om bijscholingstrajecten. Opscholingstrajecten komen met name voor in het grootwinkelbedrijf."

Tabel 3.10 laat ook zien dat $41 \%$ van de fondsen specifieke activiteiten bekostigt, die gericht zijn op werkenden zonder startkwalificatie. Hieruit blijkt dat een aanzienlijk aantal O\&O fondsen zich duidelijk weet te richten op groepen werkenden die grote risico's lopen hun werk te verliezen vanwege competentieveroudering.

"De vraag naar niveau 2 opleidingen is aan het dalen en de vraag naar $\mathrm{MBO}$ en $\mathrm{HBO}$ neemt alsmaar verder toe. Ondernemingen zelf hebben echter vooralsnog niet de concrete behoefte op grote schaal middels EVC hun medewerkers verder op te leiden. Dat is vreemd en we vrezen dan ook dat veel managers uit het middenkader terughoudend zijn in het bieden van MBO of HBO trajecten omdat zij mensen met kennis bedreigend zouden kunnen vinden."

Een kwart van de fondsen biedt extra subsidie voor de scholing van ouderen. ${ }^{41}$ Vrouwen vormen voor iets minder dan $20 \%$ van de fondsen een specifieke doelgroep en allochtonen en werkzoekenden krijgen van iets meer dan $10 \%$ van de fondsen extra aandacht.

"Er is, nadat de vestigingswet is gewijzigd, een toename geweest van het aantal allochtonen dat een winkel is begonnen. Van die kant is nóg geen specifieke opleidingsvraag gekomen, maar wellicht dat dat in de nabije toekomst nog gaat gebeuren."

41. De leeftijdsgrens is daarbij overigens zeer variabel. In de timmerindustrie is een werknemer al oud als hij of zij ouder is dan 27. In andere sectoren ligt die grens tussen de 40 en 50. 
Ruim $40 \%$ van de O\&O fondsen blijkt echter geen enkele vorm van doelgroepenbeleid te voeren.

"Wij voeren geen doelgroepenbeleid en zien ook geen specifieke trend in de opleidingsvraag die daartoe aanleiding geeft. Enkele jaren geleden is er eens een project geweest dat zich op ouderen richtte, maar dat was echt een uitzondering."

Ten slotte blijkt dat $59 \%$ van de subsidies van O\&O fondsen naar sectorspecifieke scholing gaat. Slechts $12 \%$ van de subsidies gaat naar bovensectorale scholing. $\mathrm{Er}$ worden dus vooralsnog nauwelijks subsidies uitgekeerd voor trajecten die gericht zijn op de sectoroverstijgende mobiliteit van werkenden. Dit impliceert dat werkenden die niet langer productief inzetbaar zijn in de eigen sector vanwege competentieveroudering door belastende arbeidsomstandigheden of een krimpende werkgelegenheid slechts in zeer beperkte mate door subsidies van de O\&O fondsen in staat worden gesteld zich om te scholen voor een mogelijke baan in een andere bedrijfssector.

De opgetreden verschuiving in de bekostiging van de gevolgde scholing van werknemers naar de werkgevers (zie tabel 3.5) bevestigt dit beeld en wijst mogelijk op een nieuwe verantwoordelijkheid van de fondsen die eruit bestaat niet alleen werkgevers maar ook werknemers zelf directer te stimuleren meer in de ontwikkeling van de eigen competenties te investeren. Door de keuze van de meeste O\&O fondsen om een vraaggestuurd beleid te voeren wordt tot nu toe echter voornamelijk scholing gestimuleerd die werkgevers het meest belangrijk vinden. Hierbij gaat het doorgaans om scholing die nodig is om functiespecifieke competentieveroudering tegen te gaan. De scholing die werknemers krijgen is daardoor met name functiespecifiek, bedrijfsspecifiek of hooguit sectorspecifiek van aard. Scholing die de sectoroverstijgende mobiliteit van werknemers zou kunnen bevorderen wordt daardoor nog onvoldoende gestimuleerd. Het zou wenselijk zijn wanneer de fondsen zelf maar bijvoorbeeld ook de beschikbare Europese subsidies vaker zouden kunnen worden gebruikt voor het vergroten van de sectoroverstijgende employability van werknemers die zich binnen hun eigen sector niet langer op de arbeidsmarkt kunnen handhaven vanwege belastende arbeidsomstandigheden of de verschuivingen in de werkgelegenheidsstructuur. Ook in het SER advies Het nieuwe leren ${ }^{42}$ wordt de aanbeveling gedaan de vraaggestuurde financiering via individuele werknemers "handen en voeten te geven", omdat dit een positieve invloed zal hebben op de bereidheid van werkenden om functie- en sectorverhogende scholing te gaan volgen. Een opvallend initiatief in het kader van de sectoroverstijgende scholing, mobiliteit en employability bevordering is het experiment met de 'employability-vouchers' van de Stichting $\mathrm{A}+\mathrm{O}$ en de werkgevers en vakbonden in de metalektro (zie kader).

42. SER (2002), Het nieuwe leren, SER 02-10, Den Haag. 


\section{Ontdekcheques in de Metalektro}

In het najaar van 2003 is de Stichting $\mathrm{A}+\mathrm{O}$ conform de CAO afspraak tussen werkgevers en vakbonden gestart met het eenmalige experiment "De Ontdekcheque". De ontdekcheque of: employabilityvoucher is een cheque ter waarde van $€ 750,00$ bedoeld voor een opleiding, cursus, training, stage of oriëntatietest die niet door de bedrijven zelf betaald wordt. Deze cheque is er voor iedereen die niet onder de CAO Metalektro valt: man of vrouw, allochtoon of autochtoon, bankwerker, operator, secretaresse of directeur. Tot eind 2004 heeft de Stichting zo'n 5.000 van deze ontdekcheques te vergeven.

"Het experiment met de cheque loopt nog maar kort, maar het heeft nu al een behoorlijke impact. Ondernemers klagen over het soort opleidingen dat hun personeel wil gaan volgen. Andere ondernemers staan bij wijze van spreken te juichen van enthousiasme. De keuze die de werknemer maakt voor het volgen van een opleiding, blijkt niet altijd relevant te zijn ten opzichte van de werksituatie. De afspraak is echter in dit experiment praktisch alle aanvragen te honoreren. In het kader van employability moet je immers niet iets gaan verbieden, wat de werknemer in diens persoonlijke ontwikkeling nodig acht. Mensen moeten zich kunnen ontwikkelen zoals zij dat zelf het liefste doen en je zult zien dat mensen met plezier en geluk halen uit het volgen van opleidingen die hen écht interesseren en waar zij écht enthousiast over zijn. Dat plezier en dat geluk stralen zij uit en dat beïnvloedt de werksfeer. Mensen willen voor zo'n werkgever wat extra's doen. Of het volgen van opleidingen ook de scholingsangst van mensen zal wegnemen is niet te zeggen, maar het zou zeker mooi meegenomen zijn."

Bronnen:

Interview met Drs. E.T. Anschütz, Directeur van de Stichting Arbeidsmarkt en Opleiding. Stichting A+O (2003). Voorlichtingskrant Ontdekcheque, Leidschendam, September 2003.

\subsection{Het gebruik van middelen uit het Europese Sociale Fonds (ESF 3)}

De informatie over de bestedingen van de fondsgelden wijst er op dat de doelstelling van veel fondsen in de loop der jaren steeds verder is verruimd. Behalve de bekostiging van functiegerichte bijscholing behoort ook het stimuleren van de instroom van werkzoekenden én het stimuleren van de deelname aan het reguliere beroepsonderwijs (met name het onderwijs dat mensen van een startkwalificatie voorziet) inmiddels tot de kernactiviteiten van de meeste O\&O fondsen. Deze verruiming van de doelstellingen sluit duidelijk aan bij de accenten die in het overheidsbeleid worden gelegd. Tijdens de Europese top van 2000 in Lissabon hebben de lidstaten van de Europese Unie afgesproken dat Europa in 2010 de belangrijkste kenniseconomie ter wereld moet zijn. Het verhogen van het percentage 
werknemers met een startkwalificatie is daarop één van de speerpunten geworden van het beleid van het Nederlandse kabinet.

Samenwerkingsverbanden van werkgevers en werknemers kunnen sinds Juni 2001 in aanmerking komen voor subsidies van het Europees Sociaal Fonds (ESF). De ESF subsidieregeling loopt tot en met $2006 .{ }^{43}$ De ESF 3 subsidie geldt voor activiteiten die gericht zijn op scholing tot op het startkwalificatieniveau of verdere scholing tot op het niveau van vakopleidingen of middenkaderopleidingen. Ook bedrijfstakoverstijgende scholing gericht op mobiliteitsbevordering en activiteiten gericht op het opstellen van bedrijfs- en/of persoonlijke opleidingsplannen zijn subsidiabel. Inmiddels zijn ongeveer 53 fondsen gemandateerd om aanvragen in te dienen voor subsidie in het kader van maatregel $C .^{44}$ De aanvragen worden ingediend bij het Agentschap SZW, de uitvoerende instantie van de ESF regeling.

De O\&O fondsen hebben er in het kader van de ESF subsidieregeling van de Minister van Sociale Zaken en Werkgelegenheid een belangrijke taak bij gekregen, namelijk het coördineren van aanvragen voor subsidies ten behoeve van de cofinanciering van scholingsprojecten gericht op werkenden, werkzoekenden en het reguliere beroepsonderwijs. Tabel 3.11 laat zien dat O\&O fondsen tot 1 Juli 2003 op basis van 83 aanvragen in totaal voor iets meer dan 154 miljoen Euro aan ESF 3 subsidie toegewezen hebben gekregen. Dat is $40 \%$ van de in totaal aangevraagde ESF 3 subsidies. De overige $60 \%$ van de verstrekte subsidies ging naar Gemeenten en enkele Ministeries.

Lang niet alle gemandateerde $O \& O$ fondsen hebben echter al subsidieaanvragen ingediend bij het Agentschap SZW. Door de O\&O fondsen in de landbouw en de kwartaire dienstensector was in juli 2003 nog geen enkele ESF 3 subsidie aangevraagd. ${ }^{45}$ Maar ook in andere sectoren benutten de O\&O fondsen de door ESF 3 geboden kansen vooralsnog slechts in geringe mate, al mag verwacht worden dat het aantal aanvragen en het gebruik van ESF 3 in de tweede helft van de looptijd van het ESF 3 programma sterk zullen toenemen. Van de voor juli 2003 aangevraagde subsidies, blijkt echter dat bijna $60 \%$ van het aangevraagde subsidiebedrag op het conto van slechts drie fondsen moet worden geschreven (CA-ICT, SOL en OVP). De meeste subsidie is mede door de inspanningen van deze drie fondsen dan ook aangevraagd door de voedingssector (ruim 44 miljoen Euro), de chemie (ruim 27 miljoen) en de sector transport en communicatie (bijna 22 miljoen).

43. Projecten kunnen echter nog aangevraagd worden en doorlopen in 2007.

44. Het ESF-3 programma kent zeven verschillende maatregelen, die vallen binnen drie 'prioriteiten'. Maatregel $C$ is één van de drie maatregelen binnen de prioriteit 'behoud van een inzetbare beroepsbevolking' en richt zich op de scholing van werkenden. Voor projecten die binnen deze maatregel $\mathrm{C}$ vallen is $8 \%$ van het totale ESF-3 geld gereserveerd.

45. J. Mevissen, et al. (2003), Midterm-evaluatie ESF 3 in Nederland. Resultaten en ervaringen halverwege de programmaperiode 2000-2006; samenvattende rapportage, Regioplan Beleidsonderzoek: Amsterdam/Den Haag. 
Fondsen die nog geen gebruik maakten van ESF 3 subsidies geven vaak aan dat het veel tijd kost om de aanvragen goed voor te bereiden. Andere fondsen geven aan dat de slechte ervaringen die in het verleden met ESF zijn opgedaan, het moeilijk maken om partijen te vinden die willen deelnemen. De private cofinancieringseis vormt in de praktijk een belangrijke drempel. Het geld dat O\&O fondsen en andere sociale fondsen beschikbaar hebben voor scholing in de sector is volgens de Europese Commissie niet te beschouwen als privaat geld, maar als publiek geld en als zodanig niet als private cofinanciering in te zetten. Naast de cofinancieringseisen maken de administratieve verplichtingen het zeker voor het MKB erg om moeilijk aanvragen in te dienen.

"Bezwaarlijk is vooral dat ESF-3 subsidies voor de scholing van werkenden, als gevolg van de administratieve rompslomp én de private cofinancieringseis, feitelijk niet of nauwelijks beschikbaar zijn voor het MKB. De regelgeving is complex en aanvragers moeten aan erg veel voorwaarden voldoen. Het aanvragen van ESF-3 subsidie voor de scholing van werkenden vergt een hoge mate van deskundigheid."

"Vanuit de Stichting A en O lopen nu 19 aanvragen, van vooral grote bedrijven die in het algemeen ook al substantieel aan opleiding deden. Slechts één klein bedrijf is erg actief met het aanvragen van subsidies."

De belangstelling voor ESF 3 subsidies is de laatste tijd overigens wel flink aan het toenemen. Uit meer recente informatie van het Agentschap SZW blijkt dat er in april 2004 reeds 265 aanvragen waren gehonoreerd voor een totaal subsidiebedrag van 286 miljoen euro en een beoogd deelnemersaantal van ruim 350.000 werkenden.

Uit gesprekken met de O\&O fondsen blijkt dat de ESF subsidies mogelijk ook een nuttige rol kunnen vervullen voor het enigszins op peil houden van de scholingsactiviteit in de huidige recessieperiode.

"We zien wel een toename van de belangstelling voor ESF en andere subsidies. De slechte vooruitzichten voor de sector zijn daarvoor waarschijnlijk medeverantwoordelijk. De laagconjunctuur heeft immers een zuigende werking op de subsidies. Vooral grotere bedrijven die voorheen met gepaste trots weigerden subsidie aan te vragen vragen nu juist wél subsidies aan."

Een vergelijking van de resultaten uit tabel 3.11 met kolom 4 van tabel 3.7 laat overigens zien dat vooral in de sectoren waar O\&O fondsen relatief grote reserves hebben weinig ESF subsidie wordt aangevraagd. Zo is er in de bouwsector slechts 4,6 miljoen Euro aan ESF subsidie aangevraagd. Dit kan een aantal oorzaken hebben. Allereerst is de behoefte aan extra subsidie waarschijnlijk kleiner bij fondsen die al over ruime middelen beschikken. Daarnaast speelt de private cofinancieringseis bij ESF 3 subsidie aanvragen mogelijk een rol. De middelen die bedrijven 
in het verleden hebben afgedragen aan de fondsen worden, zoals reeds werd aangegeven, door de Europese Commissie beschouwd als publieke middelen, omdat de fondsen onderdeel zijn van een algemeen verbindend verklaarde CAO. Daardoor kunnen deze middelen niet worden gebruikt voor de cofinanciering van een ESF 3 subsidie aanvraag. In de sectoren waar de bedrijven al een relatief grote reserve aan fondsmiddelen hebben opgebouwd, zal het animo van bedrijven om daarnaast nog extra middelen te genereren voor de cofinanciering van ESF 3 subsidies echter gering zijn.

Tabel 3.11

ESF 3 subsidies aangevraagd door O\&O fondsen, per bedrijfssector, tot 1-7-2003

\begin{tabular}{lcc}
\hline Bedrijfssector & Aantal aanvragen & $\begin{array}{c}\text { Toegewezen } \\
\text { In miljoenen } €\end{array}$ \\
& & 0 \\
Landbouw en visserij & 0 & 44,3 \\
Voeding & 7 & 27,5 \\
Chemie & 4 & 10,4 \\
Metalektro & 19 & 11,9 \\
Overige industrie & 4 & 2,3 \\
Energie & 3 & 4,6 \\
Bouw & 1 & 16,4 \\
Handel & 6 & 21,8 \\
Transport en communicatie & 16 & 0,6 \\
Bank- en verzekering & 2 & 12,6 \\
Horeca en zakelijke dienstverlening & 20 & 0 \\
Kwartaire diensten & 0 & 2,3 \\
Overheid en onderwijs & 1 & 154,5 \\
Totaal & 83 & \\
\end{tabular}

Bron: Agentschap SZW, 2003

“Bedrijven nemen ten aanzien van ESF geen risico's meer en hebben geen zin meer in alle problemen en rompslomp rondom een ESF aanvraag. Eén van de belangrijkste oorzaken voor het feit dat veel subsidiegeld blijt liggen is dan ook de kopschuwheid van bedrijven."

"Bij aanvang van ESF-3 was er voor de fondsen die de aanvragen deden nog wat discussie- en interpretatieruimte voor wat betreft de precieze regelgeving. Die ruimte is steeds meer beperkt door ad-hoc aanpassingen van regels en procedures. Eenduidigheid en continuïteit in de regelgeving en procedures rondom ESF-3 subsidies voor de scholing van werkenden zou de beschikbare middelen toegankelijker kunnen maken".

Ook het aanbestedingsmodel dat wordt gebruikt voor de toekenning van subsidies in het kader van de ESF-3 regeling wordt genoemd als een drempelverhogende factor.

"Het aanbestedingsmodel stuit in veel bedrijven op onbegrip en wordt als een onnodig complicerende factor ervaren. Vooral voor grotere bedrijven met hun eigen opleidingsinstituut is het onzinnig te verlangen dat er drie offertes van opleidingsinstituten worden meegestuurd met een subsidieaanvraag. Opleidingsinstituten gaan vanzelfsprekend 
geen tijd steken in het opstellen van een offerte als ze van tevoren al weten dat ze geen enkele kans maken op een opdracht. Het verkrijgen van de benodigde offertes is daarom voor zowel de aanvragende partijen als voor veel opleidingsinstituten tijd- en geldverspilling."

In de metalektrosector blijkt slechts $5 \%$ van de bedrijven tot op heden gebruik te maken van ESF 3 subsidies. Bij de bedrijven die gebruik maken van ESF subsidie, wordt in totaal $18 \%$ van de totale scholingskosten bekostigd uit de subsidiegelden. Dit is ongeveer een even grote bijdrage als de subsidies van het $A \& O$ fonds leveren aan de bekostiging van de scholingsuitgaven van de metalektrobedrijven. $80 \%$ van de bedrijven geeft aan dat de ESF subsidies een duidelijk positief effect hebben op de cursusparticipatie van hun technisch personeel. Voor de A\&O subsidies is dat slechts bij $57 \%$ van de metalektrobedrijven het geval. ${ }^{46}$

\section{De besteding van ESF subsidies}

Onderzoek naar de besteding van de ESF subsidies laat onder andere zien dat de middelen vooral worden ingezet voor projecten gericht op het voorkomen van competentieveroudering, waardoor mensen niet meer goed zouden kunnen functioneren in hun huidige functie (zie tabel 3.12). Van de 28 onderzochte projecten waren er 21 hierop gericht. Het door middel van scholing vergroten van de kansen op de externe arbeidsmarkt behoorde voor 11 projecten tot de doelstellingen. Meer dan de helft van de onderzochte projecten is gericht op het vergroten van de externe mobiliteit bínnen de branche. Slechts 4 van de 28 projecten hebben tot doel de externe mobiliteit buiten de eigen branche te vergroten.

Tabel 3.12

Doel van projecten waarvoor subsidie werd verkregen

\begin{tabular}{lc}
\hline & $\begin{array}{c}\text { Aantal projecten } \\
(\mathrm{N}=28)\end{array}$ \\
\hline Blijven functioneren in huidige functie & 21 \\
Nieuwe functie bij het huidige bedrijf & 18 \\
Behalen van startkwalificatie & 14 \\
Vergroten kansen externe arbeidsmarkt & 11 \\
Gericht op positie bínnen het bedrijf & 14 \\
Vergroten externe mobiliteit binnen de branche & 16 \\
Vergroten externe mobiliteit buiten de branche & 4 \\
\hline
\end{tabular}

Bron: Regioplan (2003)

Dit betekent dat ook de ESF middelen met name worden ingezet voor het bekostigen van sectorspecifieke scholingstrajecten. Een van de doelstellingen die voortvloeit uit het Enig Programmeringsdocument Europees Sociaal Fonds Doelstelling 3, namelijk dat $\mathrm{O} \& O$ fondsen uit verschillende bedrijfstakken meer aandacht zouden moeten schenken aan samenwerking, wordt daarmee tot op heden onvoldoende

46. A. de Grip, J. van Loo en I. Sieben (2004), Arbeidsmarktmonitor Metalektro 2003, ROA-R2004/2, Maastricht. 
gerealiseerd. Sectoroverstijgende scholing en mobiliteit krijgt echter de laatste jaren langzaam maar zeker meer aandacht.

"De trend in de opleidingen waarvoor subsidie wordt aangevraagd is dat er steeds meer aandacht is voor bredere opleidingen. Niet alleen voor de voor elk bedrijf min of meer verplichte veiligheidscursussen, maar ook voor algemene cursussen zoals computercursussen of cursussen gericht op managementvaardigheden wordt ESF subsidie aangevraagd."

Ook projecten gericht op die sectoroverstijgende scholing en mobiliteit krijgen mede onder impuls van de sociale fondsen langzaam maar zeker meer aandacht. Recentelijk is bijvoorbeeld door enkele samenwerkende branches een aantal subsidieaanvragen ingediend. ${ }^{47}$ De Stichting Opleidingsfonds Groothandel heeft bijvoorbeeld 11,5 miljoen Euro subsidie toegewezen gekregen voor een project dat zich richt op het voorkomen van de uitval van medewerkers door het aanbieden van gerichte ARBO-, PC-, export- en communicatietrainingen. Ook enkele andere branches participeren in dit project (busbedrijven en detailhandel) en er wordt overleg gevoerd over sectoroverstijgende samenwerkingsverbanden met de branche transport en logistiek.

"De Stichting A en O coördineert ook een aantal clusteraanvragen. De aanvragen van meerdere bedrijven worden geclusterd omdat opleidingen waarvoor subsidie wordt aangevraagd grote gelijkenis vertonen. In dat kader behoort ook samenwerking met andere fondsen, zoals de OOM, het fonds voor de kleinmetaal, tot de mogelijkheden."

De initiatieven van enkele fondsen daargelaten is er over het algemeen, zo blijkt ook uit tabel 3.12 nog maar weinig structureel beleid wordt gevoerd dat gericht is op de omscholing van werkenden die zich vanwege competentieveroudering in welke vorm dan ook niet meer op de arbeidsmarkt van hun huidige sector kunnen handhaven. Wel is er steeds meer sprake van onderling overleg en onderlinge afstemming van bijvoorbeeld brede scholingstrajecten, zodat kennis wel steeds meer onderling uitwisselbaar wordt. Sectoroverstijgende mobiliteit wordt daarmee in zekere zin wel steeds meer gefaciliteerd.

Het evaluatieonderzoek van Regioplan toont ook aan dat ESF subsidies nauwelijks aan de scholing van vrouwen worden besteed (zie tabel 3.13). Slechts $11 \%$ van de deelnemers aan de 20 onderzochte scholingsprojecten is vrouw, terwijl in 1999 nog $20 \%$ van de door O\&O fondsen gesubsidieerde projecten door vrouwen werd gevolgd. De geringe deelname van vrouwen aan de ESF 3 scholingsprojecten is overigens eenvoudigweg het gevolg van het feit dat de ESF 3 subsidies vooral zijn aangevraagd in sectoren waar relatief veel mannen werkzaam zijn.

47. Zie: Nieuwskrant Agentschap SZW, (2003), Special voor O\&O fondsen, ESF Doelstelling 3, Den Haag. 
Een zelfde ontwikkeling doet zich voor bij de oudere werknemers. Terwijl in 1999 nog bijna een kwart van de door O\&O fondsen gesubsidieerde projecten specifiek gericht was op ouderen (zie tabel 3.10), is slechts $11 \%$ van de deelnemers aan ESF gesubsidieerde scholing ouder dan 50 jaar. Dat terwijl van de totale beroepsbevolking bijna $20 \%$ in die leeftijdscategorie valt. Dit wijst erop dat de inzet van ESF middelen slechts een beperkte bijdrage levert aan het curatieve beleid gericht op mensen die reeds te kampen hebben met één of meerdere vormen van competentieveroudering.

Tabel 3.13

Deelnemers aan ESF gesubsidieerde scholing

Geslacht

Man

Vrouw

Leeftijd

$<30$ jaar

31-40 jaar

41-50 jaar

$>50$ jaar

Bron: Regioplan (2003)

ESF gelden worden vooral ingezet voor de scholing van mannen in de leeftijdscategorie 30 tot 50 jaar oud. Hieruit zou men kunnen afleiden dat de inzet van ESF subsidiemiddelen eerder een preventief karakter ter voorkoming van de competentieveroudering van de werkenden die reeds het best inzetbaar en doorgaans ook het meest productief zijn.

"De Stichting A en O voert in haar ESF beleid geen doelgroepenbeleid. Voorheen zijn er wel wat allochtonenprojecten en meisjesprojecten uitgevoerd, maar die projecten waren niet echt een succes, mede door de hoge uitval die optrad. De marktwerking vormt het uitgangspunt voor de Stichting. Dat houdt ook verband met de doorgeefluik-functie. De Stichting A en O promoot de mogelijkheden voor ESF subsidie, maar voert daarin geen doelgroepenbeleid. Bedrijven vragen subsidie aan, daar waar ze het nodig hebben en als ze geld nodig hebben voor allochtonenprojecten dan wordt de aanvraag net zo goed ingediend als wanneer projecten op alle werknemers betrekking hebben. In de meeste gevallen ziet de Stichting $A$ en $O$ ook niet wie er nu daadwerkelijk deelnemen aan de scholing waarvoor subsidie is verstrekt. Dat is de zaak van bedrijven zelf."

\subsection{Scholing, risicofactoren en ESF: 13 sectorprofielen}

Tot slot van dit hoofdstuk zal voor de 13 onderscheiden bedrijfssectoren een overzicht worden gegeven van: 
- de scholingsparticipatie;

- de risico's op verlies van werk vanwege competentieveroudering;

- de mate waarin de sector gebruik maakt van ESF subsidies voor scholingsactiviteiten die deze risico's zouden kunnen verminderen. Bij het sectorprofiel van de agrarische sector wordt aangegeven welke tabellen en figuren de basis vormen van deze sectorprofielen.

Voor de agrarische sector (landbouw, veeteelt en visserij) is de zeer beperkte aandacht voor ESF 3 subsidies zonder meer een aandachtspunt. De scholingsdeelname is, zo blijkt uit de tabellen 3.1 en 3.6, in het algemeen zeer beperkt. De werkgelegenheid in de landbouwsector zal echter naar verwachting de komende jaren fors blijven krimpen (zie tabel 2.1). Bovendien is de fysieke belasting van het werk in de sector relatief hoog (zie figuur 2.1) en hebben de werkenden in de landbouwsector te maken met flinke verschuivingen in de gevraagde competenties (zie figuur 2.6). Hierdoor worden de risico's van verlies van werk vanwege competentieveroudering nog vergroot. ESF-3 zou daarom in deze sector veel meer gebruikt kunnen worden ter cofinanciering van scholingsprojecten gericht op behoud van werk voor diegenen die als gevolg van de werkgelegenheidskrimp, de hoge fysieke belasting en/of de verschuivingen in de gevraagde competenties bedreigd worden met verlies van werk. Het probleem dat zich hierbij echter voordoet is dat het in de agrarische sector met name gaat om vormen van competentieveroudering die omscholing vereisen gericht op werk in andere bedrijfssectoren. Daardoor zal cofinanciering vanuit de sector vaak moeilijk gerealiseerd kunnen worden. In plaats daarvan zouden sectoroverstijgende samenwerkingsverbanden moeten worden gecreëerd, of men zou er toe moeten overgaan de vraaggestuurde financiering van scholingsactiviteiten meer via de individuele werkenden te laten lopen.

In de voedingsindustrie is er relatief veel aandacht voor ESF 3 subsidies. Op 1 Juli 2003 waren er vanuit de voedingssector 7 subsidie-aanvragen voor een totaalbedrag van ruim 44 miljoen Euro ingediend. Daarmee is de voedingssector één van de meest actieve sectoren voor wat betreft het aanvragen van ESF 3 subsidies. In de voedingssector is er de laatste jaren als een van de weinige sectoren ook sprake van een duidelijke toename van de scholingsparticipatie. Inmiddels is de voedingssector zelfs uitgegroeid tot de sector waar, na de energiesector, het meest aan scholing wordt deelgenomen. De risico's op verlies van werk vanwege competentieveroudering in de sector zijn met name gerelateerd aan de relatief hoge fysieke belasting van het werk in een aantal beroepsgroepen. Daarnaast is er meer agressief gedrag van klanten en/of collega's dan in de meeste andere sectoren. ESF 3 subsidies worden onder andere ingezet op trainingen gericht op veiligheid en hygiëne. ${ }^{48}$ Daarmee wordt ESF 3 subsidie dus duidelijk ingezet om verlies van werk vanwege competentieveroudering als gevolg van de relatief hoge fysieke en psychische belasting in het werk te voorkomen. Niet alleen veiligheid krijgt echter aandacht. Ook sectorspecifieke cursussen gericht op het bevorderen van de vakbekwaamheid en de productkennis en meer algemene scholing gericht op organisatie,

48. Zie: Nieuwskrant Agentschap SZW (2003), Special voor O\&O fondsen, ESF Doelstelling 3, Juli. 
verkoop en communicatie (Nederlands als tweede taal) krijgen veel aandacht en worden mede gefinancierd met ESF 3 subsidies.

Ook in de chemie wordt relatief veel ESF 3 subsidie aangevraagd. De scholingsdeelname in de chemische industrie is echter in de jaren 2000-2002 flink afgenomen ten opzichte van de periode 1998-2000. Dit is temeer opvallend omdat in deze sector technologische en organisatorische ontwikkelingen elkaar relatief snel opvolgen. Bovendien zal de werkgelegenheid naar verwachting de komende jaren krimpen en is er vaker sprake van agressief gedrag van collega's dat werkenden in hun sociale veiligheid aantast. Niet alleen veranderen functies dus relatief snel van inhoud en verdwijnen er de komende jaren banen, maar ook als gevolg van psychische belasting dreigt voor sommige werknemers verlies van werk. Ondanks de aanwezige risico's op competentieveroudering behoort de chemiesector, samen met de landbouw, de overige industrie en de handelssector inmiddels tot de vier sectoren met de laagste scholingsparticipatie. Waarschijnlijk hangt dit samen met het feit dat de chemiesector van oudsher een erg conjunctuurgevoelige sector is. In tijden van economische teruggang wordt de chemiesector over het algemeen relatief hard geraakt. Dat heeft vrijwel direct gevolgen voor de middelen die worden vrijgemaakt voor de scholing van werkenden. De mogelijkheden van het O\&O fonds om een anticyclisch scholingsbeleid te voeren zijn bovendien vrijwel niet aanwezig, omdat het fonds hiervoor onvoldoende reserves heeft. Wellicht dat de chemiesector door middel van de aangevraagde ESF 3 subsidies de terugval in de scholingsparticipatie enigszins kan afremmen. In de eerste twee jaar dat de subsidies beschikbaar én aangevraagd zijn is daarvan echter nog maar weinig terug te zien.

In de metalektro zijn op 1 juli 200319 aanvragen ingediend voor ESF 3 subsidie, waarmee een totaalbedrag gemoeid is van ruim $€ 10$ miljoen. De metalektro heeft de scholingsdeelname de afgelopen jaren wat zien afnemen. Echter niet meer dan in andere sectoren. Het bedrag waarvoor de metalektrosector ESF3 subsidie heeft aangevraagd is relatief hoog. In combinatie met de reserves die de fondsen in deze sector hebben opgebouwd, bieden de ESF subsidies goede mogelijkheden om adequaat in de scholing van werkenden te investeren. Omdat de werkgelegenheid in de metalektro naar verwachting de komende jaren verder zal krimpen en er bovendien sprake is van een naar verhouding hoge fysieke belasting, zou de scholing waarop wordt ingezet gericht moeten zijn op behoud van werk in de breedste zin, dus ook omscholing naar een andere sector of beroep. De namen van de projecten ${ }^{49}$ waarvoor voor 1 Juli 2003 subsidie is aangevraagd laten zien dat ESF 3 subsidie inderdaad vooral wordt ingezet op projecten waarin toekomstperspectief en employability centraal staan. Gezien de in de komende jaren fors krimpende werkgelegenheid in de sector (jaarlijks bijna $2 \%$ ) lijkt dat een goede zaak. Door de hoge fysieke belasting die het werk in de sector met zich meebrengt, is het bovendien voor de werkenden in de metalektro van belang dat ESF 3 subsidies nu ook beschikbaar komen voor (1) scholing die werknemers leert om zo goed mogelijk om te gaan met de fysiek belastende arbeidsomstandigheden die hun werk met zich

49. "Investeren in de toekomst", "Op weg naar morgen", "Employability als onderdeel van de HRM praktijk" en "Een toekomst met perspectief" zijn enkele voorbeelden. 
meebrengt, en (2) omscholing van werkenden die hun huidige functie niet of niet lang meer kunnen uitoefenen vanwege de hoge fysieke belasting die het werk met zich meebrengt.

In de overige industriesectoren wordt het minste aan scholing gedaan van alle sectoren. De fondsen in deze sector vragen met een totaal bedrag van bijna $€ 12$ miljoen euro wel redelijk wat ESF subsidie aan. Dit duidt er op dat men zich in de sector wel bewust is van de risico's die werkenden lopen op verlies van werk en dat er activiteiten worden ondernomen om competentieveroudering te voorkomen. Werknemers in de overige industriesectoren hebben over het algemeen te maken met technologische en organisatorische vernieuwingen die elkaar snel opvolgen. Bovendien hebben veel werkenden te maken met een hoge fysieke belasting van het werk, een krimpende werkgelegenheid én substantiële verschuivingen in de gevraagde competenties. Redenen genoeg om aan te nemen dat de scholingsparticipatie te gering is om werkenden tegen deze cumulatie van risico's op competentieveroudering te wapenen. ESF 3 subsidies zouden derhalve voor de sector een belangrijke toegevoegde waarde kunnen krijgen, nu de subsidie ook aangevraagd kan worden voor de financiering van (bij)scholing gericht op het inspelen op de veranderingen in de eigen functie, of scholing die de werkenden in staat stelt zo goed mogelijk om te gaan met fysiek belastende arbeidsomstandigheden. In gevallen waarin de werkgelegenheid krimpt of de fysieke belasting die het werk met zich meebrengt het voor werkenden niet langer mogelijk maakt om hun functie nog langer te blijven uitoefenen, ligt omscholing gericht op het verkrijgen van ander werk meer voor de hand. Daarbij zal het ook moeten gaan om sectoroverstijgende scholing, waar momenteel nog onvoldoende aandacht voor is.

Vanuit de energiesector kwamen er drie aanvragen voor ESF subsidie. Het betreft relatief kleine aanvragen voor een totaalbedrag van $€ 2,3$ miljoen. De energiesector onderscheidt zich doordat het de sector is met de hoogste scholingsparticipatie. Die scholing is waarschijnlijk afdoende, al wordt er in de energiesector relatief veel beeldschermwerk verricht waardoor werkenden RSI risico's lopen. Daarnaast is er sprake van veel verschuivingen in de gevraagde competenties die werkenden zich eigen moeten maken om adequaat te blijven functioneren.

In de bouwsector wordt redelijk wat aan scholing gedaan. Het is opmerkelijk dat vanuit de bouwsector slechts één aanvraag voor ESF-3 subsidies is ingediend. Mogelijk is dit toe te schrijven aan de forse reserves waarover de fondsen in de bouwsector beschikken. Hierdoor worden er wellicht minder snel subsidies aangevraagd, waarvoor cofinanciering van de bouwbedrijven vereist is. In de bouwsector is vooral de hoge fysieke belasting tijdens het werk een belangrijke oorzaak van verlies van werk vanwege competentieveroudering. Nu ESF subsidie ook aangevraagd kan worden voor scholingsprojecten gericht op de veiligheid op het werk en het beperken van de fysieke belasting, zal er vanuit de bouwsector mogelijk meer belangstelling komen voor het aanvragen van ESF-3 subsidies. Daarvoor is het uiteraard gewenst dat de fondsen in de bouwsector bekend zijn met deze nieuwe mogelijkheden. Vermoedelijk vormt het feit dat de middelen van de fondsen niet als cofinanciering van de ESF aanvragen kunnen worden ingezet echter voor veel 
bedrijven in de bouwsector een belangrijke drempel om voor hun scholingsactiviteiten ESF 3 te gebruiken.

De handelssector kent het grootste aantal O\&O fondsen. Daarvan mogen er echter maar enkelen aanvragen indienen voor ESF 3 subsidies. Met 6 aanvragen waarmee in totaal een bedrag van ruim $€ 16$ miljoen gemoeid is, is de sector echter wel vrij actief te noemen. De scholingsinspanningen blijven in de sector echter al langere tijd wat achter bij die in andere sectoren. De handel behoort dan ook nog steeds tot de sectoren met de laagste scholingsparticipatie. De scholingsdeelname is bovendien flink aan het afnemen (zie tabel 3.1). Dit zal voor een belangrijk deel het gevolg zijn van het feit dat de handelssector een erg conjunctuurgevoelige sector is, waardoor de scholingsparticipatie in de huidige recessie sterk is afgenomen. De aandacht voor ESF 3 subsidies is echter relatief groot en de scholingsparticipatie zou de komende jaren met behulp van deze subsidies dan ook weer wat kunnen aantrekken. Gezien de risico's op verlies van werk vanwege competentieveroudering in de handel zou ESF 3 subsidie kunnen worden aangevraagd voor trainingen die gericht zijn op het beter omgaan met agressief gedrag van klanten. In de detailhandel wordt overigens al veel gedaan aan het bevorderen van de sociale veiligheid van werkenden in de sector. Dat gebeurde in het verleden onder andere met ESF 4 subsidie. ${ }^{50}$ Wellicht dat nu de ESF 3 subsidie ook kan worden aangevraagd voor scholing gericht op veilig werken, er weer nieuwe initiatieven kunnen worden genomen, gericht op het bevorderen van de veiligheid in de winkel. Daarnaast vormt de omscholing van diegenen die als gevolg van agressief gedrag van klanten en daarmee samenhangende psychische klachten hun functie niet meer kunnen uitoefenen een belangrijk aandachtspunt.

In de sector transport en communicatie wordt na de voedingssector en de chemie de meeste ESF 3 subsidie aangevraagd. De 16 aanvragen die op 1 juli 2003 vanuit de sector waren ingediend (en toegewezen) vertegenwoordigen een totaalbedrag van bijna $€ 22$ miljoen. ${ }^{51}$ Dat er relatief veel ESF 3 subsidie werd aangevraagd, ligt ook in het verlengde van het feit dat de scholingsparticipatie in de sector - in tegenstelling tot in veel andere sectoren - de afgelopen jaren nauwelijks is gedaald. De scholingsparticipatie is overigens nog altijd niet hoog te noemen. In veel gevallen is subsidie aangevraagd voor projecten gericht op scholing van werkenden in ICT bedrijven. "Scholing in de ICT" en "Vakscholing ICT" zijn enkele voorbeelden van deze sectorspecifieke scholingsprojecten. Daarnaast wordt ESF 3 subsidie gebruikt voor het opstellen van de opleidingsplannen van een aantal grote ICT bedrijven. Hier betreft het eveneens sectorspecifieke of zelfs bedrijfsspecifieke scholing. Voor de transportbranche, waar het risico op competentieveroudering en verlies van werk vanwege een krimpende werkgelegenheid relatief groot is, is het echter van belang dat er voldoende wordt geïnvesteerd in sectoroverstijgende scholing. De scholings-

50. Stichting Opleidingsfonds Detailhandel (2002), Beleidsplan Stichting Opleidingsfonds Detailhandel 2003-2004.

51. De meeste aanvragen komen van het Centrum Arbeidsvraagstukken Informatie en Communicatie Technologie (CA-ICT), Het CA-ICT heeft in totaal 33 aanvragen ingediend voor bedrijven in drie verschillende bedrijfssectoren (metalektro, horeca en zakelijke dienstverlening en transport en communicatie). 
participatie in de transportbranche ligt overigens op een relatief laag niveau. Dit heeft mogelijk te maken met de relatief hoge tijdsdruk, waarmee veel van de werkenden in de sector te maken hebben. Om hen te bewegen meer aan scholing deel te nemen gericht op het behoud van werk, zou wellicht eerst iets gedaan moeten worden aan de tijdsdruk. Chauffeurs, die tijdens hun werk te maken hebben met een hoge tijdsdruk, zouden in dit kader een belangrijke doelgroep kunnen vormen.

Het bank- en verzekeringswezen onderscheidt zich momenteel als de sector waar de werkenden met de meeste risico's op verlies van werk vanwege competentieveroudering worden geconfronteerd. Niet alleen hebben technologische en organisatorische ontwikkelingen een grote impact op de inhoud van het werk, ook combineren veel werkenden langdurig computerwerk met een hoge tijdsdruk, waardoor werkenden het risico lopen op verlies van werk vanwege RSI. Bovendien hebben werkenden in het bank- en verzekeringswezen relatief vaak te maken met zowel agressief gedrag van klanten als agressief gedrag van collega's of leidinggevenden. Gezien al deze risico's is het niet verwonderlijk dat er in de sector naar verhouding veel aandacht is voor scholing. ESF 3 subsidies worden echter nauwelijks aangevraagd. In de eerste twee jaar dat ESF 3 beschikbaar was zijn slechts twee aanvragen ingediend. Daarmee was niet meer dan $€ 600.000$,- gemoeid. Deze aanvragen zijn overigens niet ingediend door een O\&O fonds binnen de sector banken verzekeringswezen, maar door het CA-ICT. ${ }^{52}$ Doordat de banksector geen O\&O fonds heeft, en dus ook geen fonds dat als zodanig is geregistreerd bij het Agentschap SZW, is het voor banken iets lastiger om subsidies voor ESF 3 aan te vragen aangezien zij een ander fonds moeten benaderen. Gezien de risico's op verlies van werk vanwege competentieveroudering die de werkenden in de sector lopen, ligt het echter wel voor de hand dat wordt nagedacht over het verbeteren van de beschikbaarheid van de ESF 3 subsidies voor de financiële instellingen. Zeker nu er ook subsidies kunnen worden aangevraagd voor scholingsprojecten gericht op het verbeteren van bijvoorbeeld de werkhouding en het voorkomen van (gedeeltelijk) verlies van werk als gevolg van bijvoorbeeld RSI. In het verzekeringswezen is één O\&O fonds actief, dat echter (nog) niet behoort tot de fondsen die een aanvraag kunnen indienen voor ESF subsidie.

Tot 1 juli 2003 zijn de meeste ESF 3 subsidie aanvragen ingediend door fondsen in de horeca en zakelijke dienstverlening: 20 aanvragen, waarmee in totaal ruim $€ 12,5$ miljoen is gemoeid. Vooralsnog is de scholingsparticipatie in de sector niet meer dan gemiddeld (zie tabel 3.1) en bovendien is de scholingsdeelname de afgelopen jaren, evenals in veel andere sectoren, met zo'n 10\% punt gedaald. Het lijkt er dus op dat de ESF 3 subsidies voor een welkome stimulans van de scholingsparticipatie zouden kunnen zorgen. Gezien het feit dat met name beeldschermwerk en een hoge tijdsdruk in de zakelijke dienstverlening een grote rol spelen en competentieveroudering als gevolg van deze beide factoren een relatief recent verschijnsel is, is het belangrijk om in deze sector scholingsprojecten gericht op het voorkomen van verlies van werk als gevolg van RSI van de grond te krijgen en daarnaast aandacht

52. Het betreft 2 aanvragen, één in naam van een de SNS bank NV en één in naam van de verzekeraar Interpolis NV. 
te hebben voor de omscholing van werkenden die als gevolg van RSI hun huidige werk niet meer goed kunnen uitoefenen. De inzet van ESF 3 subsidies zou hieraan een waardevolle bijdrage kunnen leveren.

Behalve beeldschermwerk en een hoge tijdsdruk vormt met name in de horeca ook agressief gedrag van klanten een risicofactor, die tot verlies van werk kan leiden. Het is overigens gezien de risico's op competentieveroudering en de afnemende én relatief geringe scholingsparticipatie in de horecasector opvallend dat de bij het Agentschap SZW geregistreerde fondsen in de horeca vóór 1 juli 2003 geen enkele subsidie aanvraag hebben ingediend, terwijl zij daartoe wel bevoegd zijn.

Vanuit de kwartaire dienstensector (voornamelijk de gezondheidszorgsector) waren er in juli 2003 nog geen aanvragen voor ESF 3 subsidie ingediend. Daarmee laat de sector duidelijk middelen liggen om de vele risico's op verlies van werk als gevolg van competentieveroudering te beperken door het initiëren van de noodzakelijke bijof omscholingsactiviteiten. Vooral de hoge tijdsdruk waaronder er in de gezondheidszorg wordt gewerkt en de agressie van patiënten waar nogal wat werkenden in de sector mee te maken krijgen, vormen belangrijke risico's op verlies van werk, waarop door het geven van trainingen zou kunnen worden ingespeeld. Daarnaast vormen ook de snelle ontwikkelingen op technologisch en organisatorisch vlak en de verschuivingen in de gevraagde competenties belangrijke risicofactoren voor de werkenden in de kwartaire dienstensector. Enkele fondsen in de sector zijn overigens wel door het Agentschap SZW gerechtigd om aanvragen te doen voor ESF 3 subsidies. $^{53}$

Vanuit de sector overheid en onderwijs er is slechts één aanvraag ingediend voor ESF 3 subsidie. Deze aanvraag komt uit de hoek van de gemeentelijke overheid. Mogelijk is er maar weinig animo voor ESF 3 subsidies, omdat de scholingsparticipatie in de sector al erg groot is, waardoor het aanvragen van scholingssubsidies weinig prioriteit geniet. $\mathrm{Er}$ is de laatste paar jaren echter wel sprake van een daling van de scholingsdeelname, maar deze daling is niet groter dan in andere sectoren. De afname van de scholingsparticipatie verdient overigens wel bijzondere aandacht, omdat met name snelle technologische en organisatorische vernieuwingen het risico op verlies van werk vanwege competentieveroudering vergroten. Zonder adequate bijscholing zijn deze vernieuwingen moeilijk bij te benen. ESF 3 subsidies zijn tot nu toe aangevraagd om lager opgeleide ambtenaren (op) te scholen, maar zouden bijvoorbeeld ook kunnen worden ingezet voor trainingen gericht op het voorkomen van RSI.

In het onderwijs is er, opmerkelijk genoeg, geen aandacht voor het aanvragen van ESF 3 subsidies voor de scholing van leerkrachten of ander onderwijspersoneel. Zeker nu het mogelijk wordt om ESF 3 subsidies aan te vragen voor scholing gericht op veiliger werken en het (om)scholen van werkenden die als gevolg van fysiek of psychisch belastende arbeidsomstandigheden slecht in staat zijn de huidige functie

53. Het gaat hier om de Stichting Arbeidsmarktbeleid Zorg en Welzijn, Sofokles (academische ziekenhuizen) en de Stichting Vakopleiding Gezondheidstechnische Beroepen. 
uit te oefenen, is het echter juist ook voor de onderwijssector zeer interessant om van deze mogelijkheden gebruik te gaan maken. De subsidies zouden hierbij bijvoorbeeld kunnen worden aangevraagd ter cofinanciering van scholingsprojecten gericht op het omgaan met bijvoorbeeld de hoge tijdsdruk in de sector of de toenemende agressie van leerlingen. ${ }^{54}$

54. P. Willemsen (2003), Arborisico's in de branche: Onderwijs, TNO Arbeid: Hoofddorp. 


\section{De effectiviteit van scholingsinspanningen}

\subsection{Inleiding}

Zoals in hoofdstuk 1 al naar voren kwam, is het scholen van werknemers een belangrijk middel om competentieveroudering tegen te gaan. In het vorige hoofdstuk werd de scholing van werkenden uitgebreid geanalyseerd. Hierbij werd de scholingsdeelname vanuit verschillende invalshoeken belicht. Het deelnemen aan een bepaalde scholingsactiviteit zegt echter nog weinig over de effectiviteit van de scholinginvesteringen. De effectiviteit van scholing kan op verschillende manieren worden geanalyseerd. Zo kan er bijvoorbeeld gekeken worden naar de mate waarin bepaalde opleidingen bijdragen aan het competentieniveau van werknemers: Levert de deelname aan scholing ook werkelijk iets op in termen van de ontwikkeling van iemands competenties? Daarnaast kan er gekeken worden naar de effectiviteit van verschillende soorten scholing bij het verminderen van het risico op verlies van werk vanwege competentie-veroudering.

In dit hoofdstuk zal de effectiviteit van scholing nader worden geanalyseerd. De eerste analyse richt zich op de vraag in hoeverre er een duidelijke relatie is tussen het volgen van bepaalde soorten scholing en het competentieniveau van werknemers (zie paragraaf 4.2). De tweede analyse richt zich op de vraag in hoeverre het volgen van scholing kan bijdragen tot het verminderen van het risico op verlies van werk vanwege de competentieveroudering waarmee iemand te kampen heeft (zie paragraaf 4.3). In paragraaf 4.4 combineren we de cijfers over de scholingsparticipatie in de verschillende bedrijfssectoren uit het vorige hoofdstuk met de mate waarin de verschillende soorten scholing bijdragen aan het competentieniveau van werkenden uit paragraaf 4.2. Dit geeft een indicatie van de mate waarin er in de verschillende bedrijfssectoren sprake is van een effectieve scholingdeelname. Paragraaf 4.5 sluit het hoofdstuk af met enkele conclusies.

\subsection{Scholingsdeelname en competentieniveau}

Helaas is er geen informatie beschikbaar over de competentie-ontwikkeling van de gehele werkzame bevolking. Het effect van scholing op de ontwikkeling van het competentieniveau van werkenden kan echter wel worden geanalyseerd met behulp van de gegevens uit het SchoolverlatersInformatieSysteem (SIS) van het ROA (zie ook paragraaf 2.4). Het SIS is een groot opgezette enquête onder schoolverlaters van het Nederlandse onderwijs die circa anderhalf jaar na het behalen van hun diploma schriftelijk of via internet worden bevraagd over uiteenlopende onderwerpen. Daarbij wordt er onder meer aandacht besteed aan de arbeidsmarktsituatie, de kenmerken van de baan die men heeft, de aansluiting tussen de gevolgde opleiding en de huidige baan, de eventueel gevolgde om- of bijscholing en het niveau van bepaalde competenties. 
Aangezien het SIS alleen gegevens over schoolverlaters bevat, wordt het effect van scholing op de ontwikkeling van het niveau van de competenties van werkenden in feite alleen geanalyseerd voor de starters op de arbeidsmarkt. Aangenomen mag worden dat deze analyses echter ook van belang zijn voor werknemers die al langere tijd op de arbeidsmarkt actief zijn. Juist het feit dat de analyses uitgevoerd worden met een qua werkervaring relatief homogene groep van startende schoolverlaters, kan zelfs meer betrouwbare informatie opleveren over de effectiviteit van scholing.

Opzet van de analyse

De beschikbare informatie maakt het ook mogelijk een onderscheid te maken tussen de effectiviteit van verschillende soorten cursussen. In totaal kunnen tien verschillende soorten cursussen worden onderscheiden:

- Cursus automatisering, tekstverwerking

- Cursus administratie, economisch.

- Cursus talen, verzekeringen, commercieel

- Cursus communicatie, leidinggeven, managementtraining

- Cursus recht, bestuurlijk, juridisch

- Cursus techniek

- Cursus vervoer, transport

- Cursus milieu, veiligheid, arbeidsomstandigheden

- Cursus medisch, verplegend en verzorgend

- Andere cursussen

Ook het competentieniveau van werknemers kan op verschillende manieren in beeld worden gebracht. Zo kan er bijvoorbeeld gekeken worden naar sterk beroepsgebonden competenties, zoals bijvoorbeeld de in een bepaald beroep vereiste vakkennis, maar ook naar meer algemene competenties zoals bijvoorbeeld het kunnen leidinggeven of zelfstandig werken. In totaal worden er tien verschillende competenties onderscheiden, waarvan er twee vakspecifiek zijn en acht als meer algemene competenties kunnen worden gezien:

Vakspecifieke competenties

- Vakkennis

- Gebruik van vakkennis in de praktijk

Algemene competenties

- IT-vaardigheden

- Plannen en organiseren

- Communicatieve vaardigheden

- Werken in teamverband

- Zelfstandigheid

- Initiatief/creativiteit

- Aanpassingsvermogen

- Nauwkeurigheid 
Voor deze tien competenties wordt het door de respondenten aangegeven competentieniveau (op een 5-punts schaal) gerelateerd aan de eventueel gevolgde cursussen. Bij de analyses wordt uiteraard ook gecorrigeerd voor de bedrijfssector en het beroep waarin iemand werkzaam is, de initiële opleiding die men heeft gevolgd en de leeftijd en het geslacht van de werkende. Figuur 4.1 geeft een overzicht van het onderzoeksmodel.

Figuur 4.1

Onderzoeksmodel voor de relatie tussen scholingsdeelname en het niveau van de competenties

\section{Scholingsdeelname}

Cursus automatisering, tekstverwerking

Cursus administratie, economisch.

Cursus talen, verzekeringen, commercieel

Cursus communicatie, leidinggeven, managementtraining

Cursus recht, bestuurlijk, juridisch

Cursus techniek

Cursus vervoer, transport

Cursus milieu, veiligheid, arbeidsomstandigheden

Cursus medisch, verplegend en verzorgend

Andere cursussen

\begin{tabular}{|l|l|}
\hline \multicolumn{1}{|c|}{ Competentieniveau } \\
Vakspecifieke competenties & Algemene competenties \\
Vakkennis & IT-vaardigheden \\
Gebruik van vakkennis in de praktijk & Plannen en organiseren \\
& Communicatieve vaardigheden \\
& Werken in teamverband \\
& Zelfstandigheid \\
& Initiatief/creativiteit \\
& Aanpassingsvermogen \\
& Nauwkeurigheid \\
& \\
&
\end{tabular}

\section{Resultaten}

In tabel 4.1 wordt een overzicht gegeven van de uitkomsten van de analyse. De tabel laat zien dat verschillende cursussen sterk uiteenlopende effecten hebben op de competenties van werkenden. Zo heeft het volgen van een cursus 'recht, bestuurlijk, juridisch' een relatief groot effect gehad op de vakkennis van degenen die een cursus op dit terrein hebben gevolgd. Ook blijkt het volgen van deze cursussen de betrokkenen beter in staat te stellen hun vakkennis in de praktijk te gebruiken. Het volgen van een cursus 'communicatie, leidinggeven' of een managementtraining blijkt eveneens een betrekkelijk groot effect te hebben op het niveau van iemands vakkennis. Dergelijke cursussen hebben ook een positief effect op de competentie van werkenden om hun vakkennis in de praktijk toe te passen. Het valt dus op dat algemeen gerichte cursussen in de praktijk grote effecten hebben op het niveau van 
iemands vakspecifieke competenties. Het niveau van de competenties op het vlak van informatietechnologie (IT) wordt, zoals verwacht mocht worden, vooral beïnvloed door cursussen automatisering en tekstverwerking. Ook het volgen van een technische cursus blijkt het niveau van de IT competenties te verhogen.

Een cursus administratie, economisch' heeft een aanzienlijk niveauverhogend effect op diverse algemene competenties. Zowel het kunnen plannen en organiseren, als iemands communicatieve vaardigheden en capaciteiten om te kunnen werken in teamverband blijken gebaat te zijn bij het volgen van een dergelijke cursus.

Zoals de tabel laat zien spelen cursussen op het gebied van 'communicatie, leidinggeven en managementtrainingen' een belangrijke rol bij de opbouw van diverse algemene competenties. Het sterkst zijn de effecten op iemands communicatieve vaardigheden, aanpassingsvermogen en creativiteit. Cursussen op het terrein van automatisering en tekstverwerking en cursussen 'recht, bestuurlijk of juridisch' blijken ook een positief effect te hebben op de nauwkeurigheid waarmee iemand werkt.

Om het totale effect van de cursusdeelname op verschillende competenties te kunnen bekijken zijn in de laatste kolom de verschillende significante effecten op de tien onderscheiden competenties gesommeerd. De drie cursussen met de grootste totale effecten zijn cursussen op het terrein van administratie, economisch', cursussen 'communicatie, leidinggeven, managementtraining' en cursussen 'recht, bestuurlijk of juridisch'. De aard van deze cursussen geeft duidelijk aan dat de scholing van werkenden vooral in de kantoorberoepen een belangrijke bijdrage levert aan de competentieontwikkeling van werkenden.

\subsection{Scholing en de kans op behoud van werk}

In de vorige paragraaf zagen we dat het volgen van scholing inderdaad een positief effect heeft op het niveau van iemands competenties. Dit brengt ons bij de vraag in hoeverre het volgen van scholing effectief is in het verminderen van het risico op verlies van werk vanwege de competentieveroudering waarmee iemand te kampen heeft.

In deze paragraaf zal hier nader op worden ingegaan. De analyses spitsen zich toe op de werkenden die, gezien hun leeftijd, het grootste risico lopen op verlies van werk vanwege competentieveroudering: de werkenden van 40 jaar en ouder. ${ }^{55}$ Voor de analyses wordt gebruik gemaakt van het OSA aanbodpanel. Allereerst is gekeken welke rol scholing speelt in het verminderen van de risico's op verlies van werk voor werkenden die in hun functie te maken hebben met fysiek of psychisch belastende werkomstandigheden, of vaak herhalende werkzaamheden moeten uitvoeren.

55. Strikt genomen hebben de analyses betrekking op de werkenden van 40-63 jaar; dit om te voorkomen dat werkenden van 63 en 64 jaar, die twee jaar later zijn gepensioneerd in de analyses worden meegenomen. 


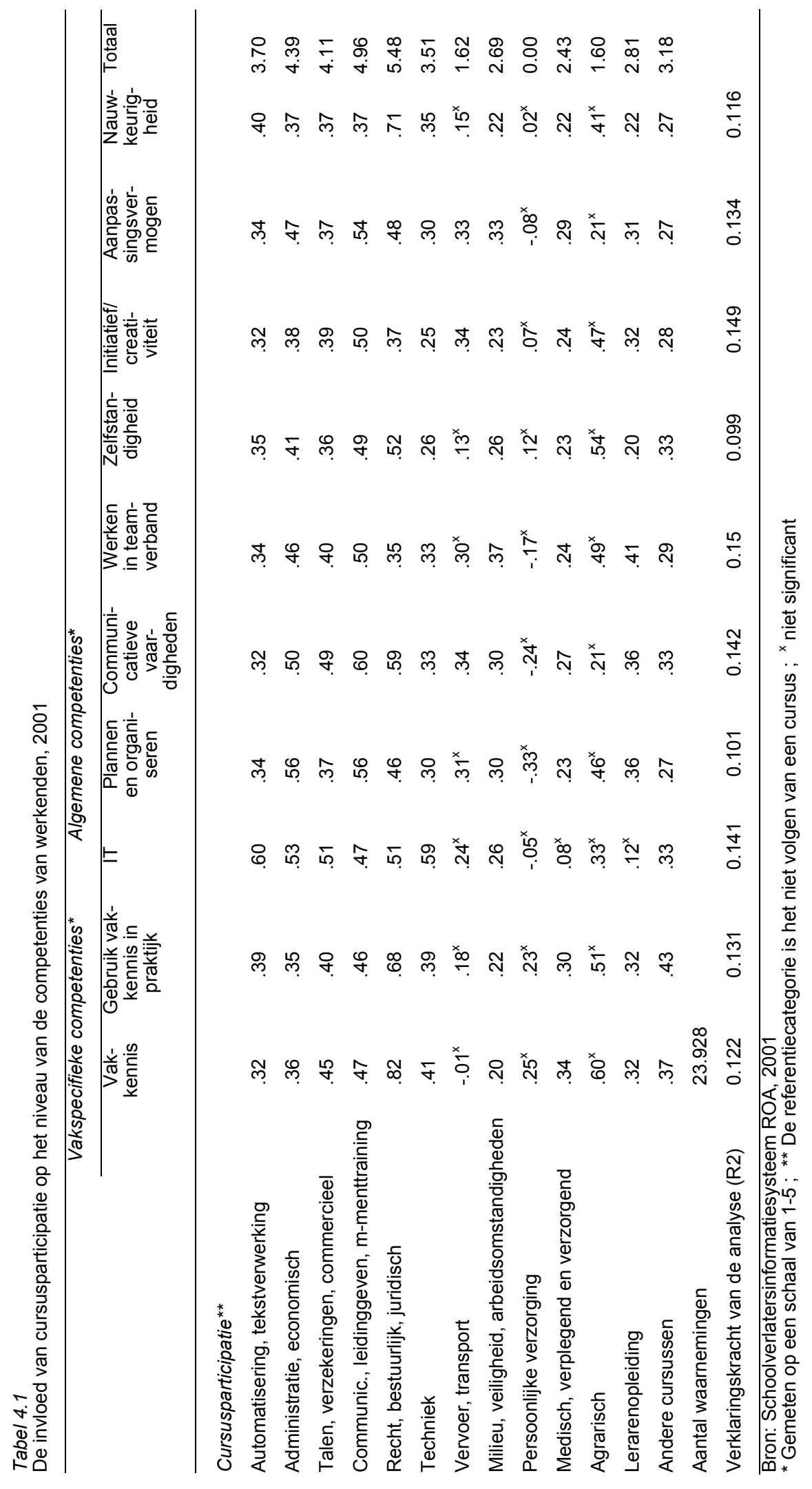


Uit tabel 4.2 blijkt dat degenen die in 1998 met belastende werkomstandigheden werden geconfronteerd en geen training volgden, inderdaad vaker hun werk verloren, terwijl dat niet het geval was bij de werkenden met belastende werkomstandigheden die wel training volgen. Het is echter opmerkelijk dat deze effecten in 2002 niet optraden. Dit zou te maken kunnen hebben met de conjuncturele situatie in 2002. In de laagconjunctuur van dat moment lopen immers ook de werkenden in functies waarin geen sprake is van belastende arbeidsomstandigheden een groter risico op verlies van werk. Uit soortgelijke analyses waarin geprobeerd wordt het risico op langdurig ziekteverzuim vanwege belastende arbeidsomstandigheden in kaart te brengen, blijkt overigens dat in geval van fysieke belasting en herhalende werkzaamheden, de werkenden die scholing volgen significant minder vaak langdurig ziek zijn. Deze effecten worden zowel in 2000 als in 2002 gevonden.

Tabel 4.2

Effecten van belastende werkomstandigheden op de kans dat werkenden hun baan verliezen, wanneer er geen training wordt gevolgd

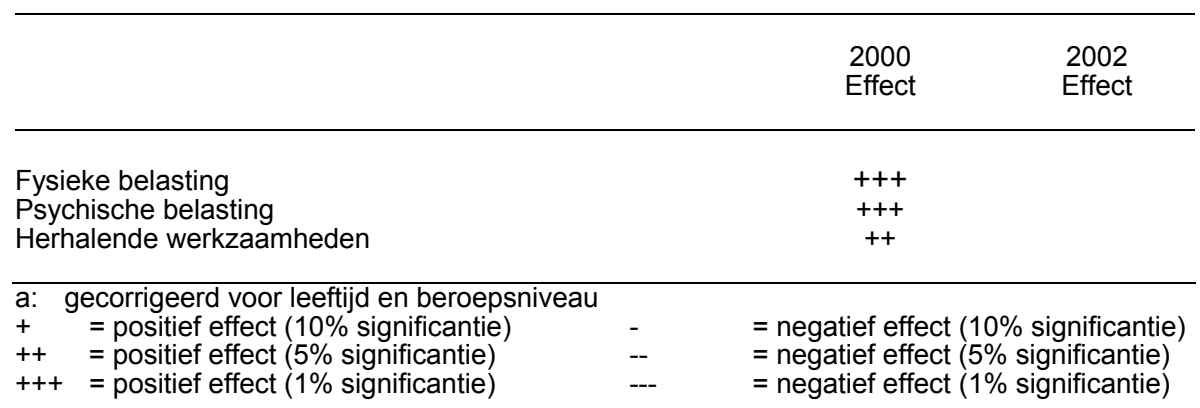

Tabel 4.3 laat zien dat scholing een belangrijke rol speelt in het verminderen van de risico's op verlies van werk. Werkenden die vaker een cursus volgen blijken zich op de middellange termijn beter op de arbeidsmarkt te kunnen handhaven. De schattingsresultaten wijzen er overigens niet op dat er een relatie is tussen de technologische en organisatorische vernieuwingen in de beroepsgroep en bedrijfssector, waarin iemand werkzaam is en het risico op verlies van werk. Dit kan echter het gevolg zijn van het feit dat de gebruikte indicatoren voor technologische en organisatorische vernieuwingen niet direct aan het bedrijf waarin een werknemer werkzaam is kunnen worden gerelateerd, maar slechts een indicatie geven van de technologische en organisatorische innovaties in de bedriffssector en de beroepsgroep waarin iemand werkzaam is. Het gaat hier om respectievelijk het percentage bedrijven in de bedrijfssector waarin iemand werkzaam is dat te maken heeft met een organisatorische verandering en het percentage werknemers in de beroepsgroep dat met computers werkt.

Wel blijkt dat werkenden die in hun werk regelmatig herhalende werkzaamheden moeten verrichten een groter risico te lopen op verlies van werk. Dit kan op twee zaken wijzen: (1) Degenen die in deze functies werkzaam zijn lopen een groter risico 
op verlies van werk vanwege de belastende arbeidsomstandigheden (RSI e.d.) ${ }^{56}$, of (2) het gaat hier om mensen die werkzaam zijn in functies waarin ze hun competenties niet verder kunnen ontwikkelen, waardoor ze op een gegeven moment, ondanks hun werkervaring, niet meer kunnen concurreren met - de vaak goedkopere - jongeren die op de arbeidsmarkt instromen. Hierbij speelt waarschijnlijk ook een rol dat lagere functies waarin veel herhalende werkzaamheden moeten worden uitgevoerd, vaak naar landen met een lager loonniveau worden verplaatst.

Daarentegen blijkt dat naast het volgen van aanvullende scholing, ook het leren op de werkplek mogelijk een rol speelt bij het verminderen van het risico op verlies van werk. Naarmate werkenden langer in hun functie werkzaam zijn, is hun risico op verlies van werk kleiner. Dit geringere risico op verlies van werk zou echter ook het gevolg kunnen zijn van de sterkere rechtspositie van mensen die reeds langer bij een bedrijf werkzaam zijn. Er blijkt wat dit betreft echter sprake te zijn van een duidelijke tegenkracht. Wanneer werkenden té lang dezelfde functie blijven uitoefenen, lopen ze een groter risico hun werk te verliezen. Het blijkt overigens geruime tijd te duren voor deze ervaringsconcentratie het geringere risico op verlies van werk vanwege de opgebouwde werkervaring overvleugelt. Gemiddeld genomen is dit pas na circa 19 jaar het geval. Wel duiden deze uitkomsten op het belang om tijdig met scholing te beginnen. Scholing kan er namelijk voor zorgen dat ervaringsconcentratie geen kans krijgt om het risico op verlies van werk te vergroten.

Tabel 4.3

Effect van scholingsdeelname op verlies van werk $^{*}$

Effect

Organisatorische veranderingen

IT gebruik

Competentietekort 2 jaar geleden

Herhalende werkzaamheden

Baanduur

Ervaringsconcentratie (baanduur kwadraat)

Aantal in verleden gevolgde cursussen (3-4 jaar geleden)

$+++$

${ }^{\bar{*}}$ Referentiecategorie: werkzaam in eerdere baan of andere baan; gecorrigeerd voor bedrijfsgrootte, beroepsniveau, geslacht, leeftijd en onderzoeksjaar.

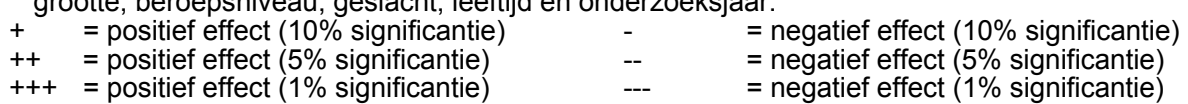

Ten slotte is het opmerkelijk dat de werkenden die zelf aangeven dat ze in hun functie te kampen hebben met een competentietekort, twee jaar later niet significant vaker hun baan verliezen. Dit zou het gevolg kunnen zijn van het feit dat werkenden die een competentietekort ervaren, er vaker toe over gaan om aanvullende scholing te gaan volgen (zie tabel 4.4). Dit wijst er op dat werkenden doorgaans adequaat inspelen op het risico op verlies van werk vanwege competentieveroudering.

56. Overigens blijken degenen die werkzaam zijn in een beroepsgroep waarin veel met computers wordt gewerkt, minder vaak te maken te hebben met herhalende werkzaamheden. 
Ook laat de tabel zien dat in de functies die, gecorrigeerd voor het beroepsniveau, relatief veel inwerktijd vragen ook relatief veel scholing wordt gevolgd. Het blijkt overigens dat juist in de functies waarin de werkenden vaak aangeven te kampen te hebben met competentieveroudering de inwerktijd lang is. Kennelijk gaat het hier om hoogwaardige functies waarin de werkenden zich doorlopend moeten inspannen om hun competenties up-to-date te houden.

Bovendien blijken werkenden die langer bij een bedrijf werkzaam zijn meer scholing te volgen. Dit wijst er op dat het opdoen van werkervaring meestal geen alternatief is voor het volgen van scholing, maar dat werkervaring en scholingsparticipatie elkaar veeleer aanvullen. Ook hier blijkt echter dat wanneer werkenden op een gegeven moment te kampen hebben met een te sterke ervaringsconcentratie, zij ook minder aan scholingsactiviteiten gaan deelnemen. Gemiddeld is dit na ruim 13 jaar het geval. Dit is 6 jaar eerder dan het moment waarop ervaringsconcentratie het risico op verlies van werk vergroot. Dit wijst erop dat wanneer mensen die lang in een bepaalde functie werkzaam zijn afhaken met het op peil houden van hun competenties, dit een voorbode is van het verlies van werk vanwege ervaringsconcentratie.

Tabel 4.4

Factoren die van invloed zijn op scholingsparticipatie*

Effect

Organisatorische veranderingen

IT gebruik

Competentietekort 2 jaar geleden

Inwerktijd

Baanduur

Ervaringsconcentratie (baanduur kwadraat)

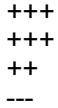

${ }^{*}$ Gecorrigeerd voor bedrijfsgrootte, beroepsniveau, geslacht, leeftijd en onderzoeksjaar.

$+\quad=$ positief effect $(10 \%$ significantie $) \quad-\quad=$ negatief effect $(10 \%$ significantie)

$++\quad=$ positief effect $(5 \%$ significantie $) \quad--\quad=$ negatief effect $(5 \%$ significantie $)$

$+++=$ positief effect $(1 \%$ significantie $) \quad---\quad=$ negatief effect $(1 \%$ significantie $)$

Een deel van de werkenden die zich niet in hun baan kunnen handhaven, lukt het om elders nog werk te vinden in een minder aantrekkelijke baan. ${ }^{57}$ Ook hier blijkt dat werkenden die meer scholing volgen minder snel hoeven uit te wijken naar een slechtere baan (zie tabel 4.5). Degenen die in hun functie veel herhalende werkzaamheden moeten verrichten blijken niet vaker uit te wijken naar een minder aantrekkelijke functie. Zoals tabel 4.3 liet zien zullen de werkenden in deze functies, wanneer ze hun vaan verliezen, zich vaak niet meer op de arbeidsmarkt kunnen handhaven. Mensen die langer bij een bedrijf werkzaam zijn, zullen minder vaak gedwongen zijn uit te wijken naar een slechtere functie. Echter, ook hier zien we dat

57. Het gaat hier om functies die qua beloning, loontrevredenheid of baantevredenheid slechter zijn dan de baan die iemand daarvoor had en op geen van de drie kenmerken beter scoort. Bij het uurloon wordt pas gesproken van een verslechtering als het verschil ten opzichte van de oude baan minstens $10 \%$ bedraagt. 
wanneer de ervaringsconcentratie erg groot wordt, men toch het risico loopt uit te moeten wijken naar een slechtere baan.

Tabel 4.5

Effecten van scholingsdeelname op het risico dat een werkende moet uitwijken naar een slechtere baan*

Effect

Organisatorische veranderingen

IT gebruik

Herhalende werkzaamheden

Competentietekort 2 jaar geleden

Baanduur

Ervaringsconcentratie

Aantal in verleden gevolgde cursussen (3-4 jaar geleden)

Bereid andere werkzaamheden te verrichten

Verricht daadwerkelijk andere werkzaamheden

Herhalende werkzaamheden

a: Referentiecategorie: behoud van eerdere baan; gecorrigeerd voor bedrijfsgrootte, beroepsniveau, geslacht, leeftijd en onderzoeksjaar.

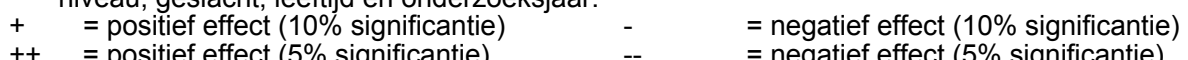

$+++=$ positief effect $(1 \%$ significantie $) \quad---\quad$ = negatief effect $(1 \%$ significantie $)$

\subsection{Effectieve scholing}

Door de gegevens over scholingsdeelname uit het vorige hoofdstuk te relateren aan de effectiviteitsindicatoren uit dit hoofdstuk, kan een beeld verkregen worden van de effectiviteit van de scholingsinspanningen die er in de verschillende bedrijfssectoren plaatsvinden. Dit resulteert in een indicator van het effect van de geleverde scholingsinspanningen op de competenties van de werkenden in een bepaalde bedrijfssector. Figuur 4.2 geeft hiervan een overzicht.

Uit de figuur komt duidelijk naar voren dat de mate waarin het volgen van scholing effectief bijdraagt aan het competentieniveau van werkenden het grootst is in het bank- en verzekeringswezen, de energiesector en de sector overheid en onderwijs. In het bank- en verzekeringswezen valt dat met name te verklaren doordat er in deze sector veel scholing wordt gevolgd die bijzonder effectief is bij de opbouw van de competenties die men nodig heeft voor het werk. Het gaat daarbij vooral om cursussen op het gebied van administratie, verzekeringen en managementvaardigheden. In de energiesector draagt met name het feit dat er op veel verschillende gebieden scholing gevolgd wordt bij tot de hoge score op de effectiviteitsindicator.

De sector overheid en onderwijs scoort hoog door de erg hoge deelname aan ITcursussen. Hoewel de effectiviteit daarvan op de competentieontwikkeling van de werkende hoog is, wijst dit op enige eenzijdigheid in de bijdrage van scholing aan de competentieontwikkeling van de werkenden in deze sector. De sectoren transport en communicatie, landbouw en visserij en de handel vallen daarentegen op door de 
geringe bijdrage die het volgen van scholing levert aan de ontwikkeling van het competentieniveau van de werkenden in deze sectoren.

\section{Figuur 4.2}

Indicator van de bijdrage van scholing aan het competentieniveau van werkenden, naar bedrijfssector

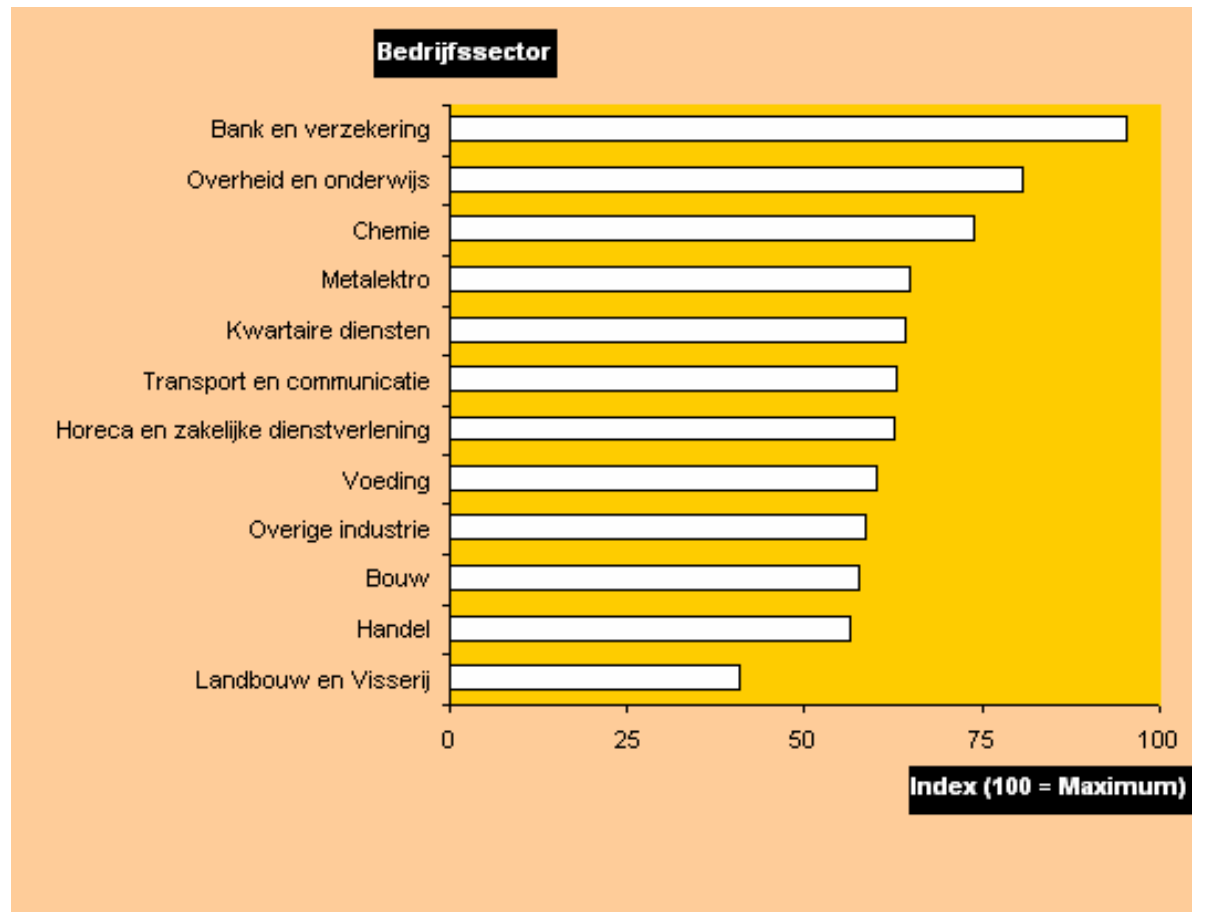

\subsection{Conclusies}

Het scholen van werknemers is een belangrijk instrument om competentieveroudering tegen te gaan. In dit hoofdstuk is ingegaan op de effectiviteit van de gevolgde scholing. Deze effectiviteit is vanuit twee perspectieven geanalyseerd. Allereerst is er gekeken naar de bijdrage die scholing levert aan de ontwikkeling van de competenties van werkenden. Vervolgens is er gekeken naar de bijdrage die scholing levert aan het verminderen van de kansen op verlies van werk vanwege competentieveroudering. Beide maatstaven voor de effectiviteit van scholing zijn met behulp van empirische analyses in kaart gebracht.

Met name het volgen van algemene cursussen blijkt een sterke invloed te hebben op het competentieniveau van werkenden. Vooral cursussen op het terrein van 'administratie, economisch', cursussen 'communicatie, leidinggeven, managementtraining' en cursussen 'recht, bestuurlijk of juridisch' leveren in de praktijk een belangrijke bijdrage aan het verhogen van het competentieniveau van werkenden. De aard van deze cursussen geeft duidelijk aan dat de scholing van werkenden vooral in de 
kantoorberoepen een belangrijke bijdrage levert aan de competentieontwikkeling van werkenden.

Bij de tweede analyse waarin de relatie tussen scholing en competentieveroudering en de kans op het behoud van werk aan de orde komt, valt het in de eerste plaats op op dat scholing de kans op verlies van werk vermindert bij fysiek of psychisch belastende arbeidsomstandigheden. Werknemers die deelnemen aan scholing lopen ook een kleiner risico op uitval door langdurige ziekte die wordt veroorzaakt door een hoge fysieke belasting of herhalende werkzaamheden.

Ook meer in het algemeen blijkt het volgen van scholing een belangrijke rol te spelen bij het verminderen van de risico's op verlies van werk vanwege competentieveroudering. Het leren op de werkplek speelt eveneens een rol bij het verminderen van de risico's op verlies van werk. Voor diegenen die al langer in hun functie werkzaam zijn is het risico op verlies van werk in eerste instantie kleiner. Echter, wanneer iemand té lang dezelfde functie uitoefent, neemt het risico op verlies van werk toe. Het negatieve effect van deze ervaringsconcentratie op het behoud van werk overvleugelt echter pas na 19 jaar het positieve effect van de langere baanduur. Het is opmerkelijk dat ervaringsconcentratie reeds 6 jaar eerder ertoe leidt dat werkenden minder vaak scholing gaan volgen. Het afhaken met het op peil houden van iemands competenties door het volgen van aanvullende scholing is derhalve een voorbode voor het verlies van werk vanwege competentieveroudering.

Een opmerkelijke constatering is ook dat de werkenden die zelf aangeven met een competentietekort te kampen te hebben, niet vaker hun baan verliezen. Dit is waarschijnlijk het gevolg van het feit dat werkenden die zelf een competentietekort ervaren vaker aanvullende scholing gaan volgen. Scholing is tenslotte ook waardevol wanneer werknemers de baan waarin ze werkzaam zijn toch verliezen. In dat geval hebben degenen die scholing hebben gevolgd, namelijk een kleinere kans dat ze moeten uitwijken naar een slechtere baan.

Om te kijken in hoeverre er in de verschillende bedrijfssectoren sprake is van effectieve scholingsinspanningen, is er een indicator geconstrueerd die een beeld geeft van de bijdrage die de in de verschillende bedrijfssectoren gevolgde scholing levert aan het competentieniveau van de werkenden. De effectiviteit van de geleverde scholingsinspanningen blijkt het hoogst te zijn in het bank- en verzekeringswezen, de energiesector en de sector overheid en onderwijs. Daarentegen levert de scholingsparticipatie in de sectoren transport en communicatie, landbouw en visserij en de handel slechts een beperkte bijdrage aan het competentieniveau van de werkenden. 



\section{Groepen met een achterstand}

\section{$5.1 \quad$ Inleiding}

Bepaalde groepen werkenden lopen een hoger risico op competentieveroudering doordat ze geconfronteerd worden met grotere risico's, of omdat ze in onvoldoende mate deelnemen aan scholing om deze risico's te beperken. In dit hoofdstuk wordt ingegaan op de specifieke problematiek die jongeren, ouderen, vrouwen en etnische minderheden kunnen ondervinden bij het verwerven en behouden van hun positie op de arbeidsmarkt.

Anders dan in voorgaande rapportages van het WSO, wordt in dit rapport de problematiek van de groepen met een nogal eens zwakkere arbeidsmarktpositie in een apart hoofdstuk behandeld. Van deze groepen kwamen de laagopgeleiden al eerder in dit rapport aan de orde, omdat er telkens werd ingegaan op de opleidingen die binnen een bedrijfssector vooral met de desbetreffende risicofactor te maken hebben. Voor de andere vier groepen worden in dit hoofdstuk uitspraken gedaan over de mate waarin zij met de verschillende risico's op verlies van werk worden geconfronteerd (zie ook hoofdstuk 2) en de mate waarin aan scholing wordt deelgenomen (hoofdstuk 3).

Het gebleken dat het voor bepaalde indicatoren op basis van de beschikbare databronnen niet mogelijk is voldoende betrouwbare informatie te verzamelen om uitspraken te kunnen doen. Dat geldt met name voor de informatie met betrekking tot de etnische minderheden.

De verdere opbouw van dit hoofdstuk is als volgt. In de volgende paragraaf wordt gekeken naar de redenen waarom de genoemde groepen werkenden aangemerkt worden als groepen die in het arbeidsmarktbeleid extra aandacht verdienen. Vervolgens kijken we in de paragrafen 5.3 - 5.5 naar de risicofactoren zoals die ook in hoofdstuk 2 aan de orde kwamen, toegespitst op de vier aandachtsgroepen. Aangezien er voor de technologische en organisatorische ontwikkelingen en de werkgelegenheidsontwikkelingen geen aparte analyses voor de aandachtsgroepen kunnen worden opgesteld, zal er in dit hoofdstuk met name gekeken worden naar de risicofactoren: fysieke belasting, pyschische belasting en het regelmatig verrichten van beeldschermwerk. Paragraaf 5.6 gaat in op de scholingsparticipatie. Paragraaf 5.7 sluit het hoofdstuk af met enkele conclusies.

\subsection{Bijzondere groepen}

De aandacht voor een aantal bijzondere groepen op de arbeidsmarkt vloeit voort uit de gedachte dat deze groepen vaker geconfronteerd worden met risicofactoren die competentieveroudering in de hand kunnen werken en bovendien minder vaak betrokken zijn bij scholingsactiviteiten die het risico van competentieveroudering kunnen verminderen. Tabel 5.1 geeft een overzicht van de mate waarin jongeren, 
oudere werknemers, vrouwen en etnische minderheden geconfronteerd worden met bepaalde risico's op verlies van werk vanwege competentieveroudering en in hoeverre deze groepen deelnemen aan scholing. Daarbij wordt de positie van deze aandachtsgroepen telkens vergeleken met het gemiddelde beeld van de totale werkzame bevolking.

Tabel 5.1

Risicofactoren en scholingsdeelname van jongeren, oudere werknemers, vrouwen en etnische minderheden in vergelijking met het gemiddelde beeld, 2001-2002

\begin{tabular}{|c|c|c|c|c|c|}
\hline & Jongeren & Ouderen & Vrouwen & $\begin{array}{l}\text { Etnische } \\
\text { Minder- } \\
\text { heden }\end{array}$ & $\begin{array}{c}\text { Totale } \\
\text { werkzame } \\
\text { bevolking }\end{array}$ \\
\hline \multicolumn{6}{|l|}{ Risicofactoren } \\
\hline Lawaai & 10 & 10 & 5 & 17 & 10 \\
\hline Trilling & 9 & 7 & 2 & 8 & 8 \\
\hline Kracht zetten & 28 & 19 & 18 & 24 & 22 \\
\hline Tijdsdruk & 23 & 32 & 28 & 28 & 29 \\
\hline Beeldschermwerk & 41 & 44 & 48 & 34 & 46 \\
\hline $\begin{array}{l}\text { Beroep met krimpende } \\
\text { werkgelegenheid 2003-'08 }\end{array}$ & 34 & 41 & 30 & 41 & 39 \\
\hline \multicolumn{6}{|l|}{ Scholingsdeelname } \\
\hline Korte opleidingstrajecten & 4 & 3 & 4 & 3 & 4 \\
\hline Lange opleidingstrajecten & 29 & 4 & 14 & 18 & 14 \\
\hline
\end{tabular}

De tabel laat zien dat etnische minderheden relatief vaak te maken hebben met een hoge fysieke belasting tijdens hun werk. Met name omdat ze regelmatig geconfronteerd worden met lawaai en tijdens hun werk regelmatig kracht moeten zetten. Bovendien zijn ze iets vaker werkzaam in beroepsgroepen met een krimpende werkgelegenheid. Voor wat betreft de scholingsdeelname van etnische minderheden is er alleen bij de korte opleidingstrajecten sprake van een bescheiden achterstand.

Vrouwen verrichten relatief veel beeldschermwerk. Doordat hun werkgelegenheid geconcentreerd is in de dienstenberoepen en kantoorberoepen werken ze relatief weinig in beroepen met een krimpende werkgelegenheid. Oudere werknemers moeten regelmatig onder een hoge tijdsdruk werken. Ouderen volgen bovendien relatief weinig scholing. Met name de participatie in langer lopende opleidingen is erg laag. Bij jonge werknemers is dat juist niet het geval. Zij nemen vaker deel aan langdurige opleidingen. Ook zijn jongeren minder vaak werkzaam in beroepen met een krimpende werkgelegenheid. Wel hebben jongeren vaak te maken met fysiek belastende arbeidsomstandigheden (met name trilling en kracht zetten).

\section{Jongeren}

Vaak wordt gedacht dat jongeren (15-24 jaar) minder participeren in scholingsactiviteiten omdat bedrijven minder in jongeren willen investeren. Jongeren bevinden zich immers in de beginfase van hun carrière en zullen daarom vaker van baan wisselen. Dit betekent dat het risico dat bedrijven lopen dat ze (een deel van) de opbrengsten van hun investeringen in de scholing van jongeren mislopen. De cijfers 
in tabel 5.1 geven echter een duidelijk ander beeld. Aan het begin van de loopbaan wordt er juist veel scholing gevolgd. Voor zowel de kortdurende als de lange scholingsdeelname blijken de jongeren in het geheel niet achter te lopen. Hierbij moet wel opgemerkt worden dat het bij de lange opleidingstrajecten gedeeltelijk gaat om BBL-opleidingen van jongeren die bij een bedrijf in dienst zijn.

Vanwege de relatief hoge fysieke of psychische belasting in het werk zouden jongeren een groter risico kunnen lopen op verlies van werk. De cijfers in tabel 5.1 laten zien dat jongeren inderdaad relatief vaak werkzaam zijn in banen met een hoge fysieke belasting. Daarentegen werken jongeren minder vaak onder een hoge tijdsdruk en verrichten ze ook minder vaak beeldschermwerk.

Ook de risico's op verlies van werk vanwege een krimpende werkgelegenheid kunnen bij jongeren hoger liggen dan bij hun wat oudere collega's. In veel organisaties raken immers de laatst aangenomen werknemers het eerst hun baan kwijt als er moet worden ingekrompen. Aan de andere kant zijn er echter in de praktijk ook binnen bedrijfssectoren vaak flinke verschuivingen in de werkgelegenheid van het ene bedrijf naar het andere. In dat geval zijn het juist de oudere werknemers in de slechter lopende bedrijven die het risico lopen op verlies van werk, terwijl de groeiende bedrijven jongeren aantrekken, die vaak goedkoper zijn en bovendien recent hun beroepsopleiding hebben gevolgd. ${ }^{58}$

De arbeidsmarktproblematiek voor jongeren ligt dan ook in het algemeen niet zozeer in het risico op verlies van werk vanwege competentieveroudering, maar veeleer in het niet kunnen krijgen van werk als ze in een recessieperiode hun arbeidsmarktintrede doen. Deze schoolverlatersproblematiek komt ook helder naar voren in de Arbeidsmarktmonitor Metalektro 2003. ${ }^{59}$ Bijna tweederde van de metalektrobedrijven geeft aan dat ze bij het werven van nieuwe technici de voorkeur geven aan iemand met relevante werkervaring boven een schoolverlater met het juiste vakdiploma. De belangrijkste redenen hiervoor zijn de inwerkkosten. Voor schoolverlaters bedraagt de gemiddelde inwerktijd bijna een jaar, terwijl mensen met enige werkervaring gemiddeld slechts 4 maanden inwerktijd nodig hebben om hun functie onder de knie te krijgen.

\section{Ouderen}

Oudere werknemers (54-65 jaar) vormen om verschillende redenen een groep met mogelijke achterstanden. Allereerst zijn deze werknemers veelal op het einde van hun carrière, wat betekent dat ze het sterkst getroffen worden door verschillende vormen van competentieveroudering. Competentieveroudering is namelijk een dynamisch proces, waarvan de effecten vaak cumuleren. Zo heeft lichamelijk belastend werk vaak pas op de lange termijn als gevolg dat iemand arbeidsongeschikt wordt.

58. Zie A. de Grip, E. Hermans en J. van Loo (2003), IT-gebruik en dynamiek op de arbeidsmarkt, Maandschrift Economie, jrg. 67, pp. 58-67.

59. A. de Grip, J. van Loo en I. Sieben (2003), Arbeidsmarktmonitor Metalektro 2003, ROA-R-2004/2, Maastricht. 
Daarnaast hebben de elkaar opeenvolgende technologische en organisatorische veranderingen vanzelfsprekend grotere gevolgen voor werknemers die al langer op de arbeidsmarkt actief zijn en derhalve al vaker met dergelijke veranderingen geconfronteerd zijn. Zowel voor technische als economische competentieveroudering mag daarom aangenomen worden dat ze zich bij oudere werknemers sterker manifesteren dan bij hun jongere collega's. Bovendien worden oudere werknemers ook nog eens vaker met technische competentieveroudering geconfronteerd omdat ze te kampen hebben met ervaringsconcentratie, tenzij ze hun competenties door het volgen van aanvullende scholing telkens op peil hebben gehouden. Bovendien is het aandeel van de laagopgeleiden onder de oudere werknemers relatief hoog. Deze laagopgeleide oudere werknemers zijn vaak actief in de lagere beroepen, waarin vaak sprake is van sterk belastende arbeidsomstandigheden en een krimpende werkgelegenheid.

Ook de veelal beperkte scholingsdeelname zorgt ervoor dat oudere werknemers vaak grote risico's lopen op verlies van werk vanwege competentieveroudering. Enerzijds heeft dat te maken met het hoge percentage laagopgeleiden onder de oudere werknemers. Anderzijds schieten echter ook de prikkels die werkgevers en de oudere werknemers zelf hebben om te investeren in het up to date houden van hun competenties vaak tekort. De periode waarin de scholingsinvesteringen kunnen renderen is immers bij oudere werknemers eenvoudigweg korter dan bij hun jongere collega's. Wel wordt daarbij vaak over het hoofd gezien dat de effecten van scholing niet de gehele loopbaan blijven duren, en dus eindig zijn. Vanuit dat perspectief kan een scholingstraject gericht op oudere werknemers dat enkele jaren de productiviteit verhoogt voor organisaties best de moeite waard zijn.

Er bestaat natuurlijk ook een wederkerige relatie tussen de scholingsparticipatie van ouderen en hun arbeidsparticipatie. De maatschappelijke wens om de arbeidsmarktparticipatie van ouderen te verhogen, agendeert daarmee ook de noodzaak om meer te investeren in scholing die de risico's op verlies van werk vanwege competentieveroudering voor oudere arbeidskrachten verkleint. De cijfers in tabel 5.1 laten zien dat de scholingsparticipatie van ouderen nog steeds op een laag niveau ligt. Zowel bij kortdurende als vooral ook bij langdurige opleidingen is de participatie van ouderen relatief laag. Overigens is de scholingsparticipatie van ouderen sinds het midden van de jaren negentig flink toegenomen ${ }^{60}$ hetgeen ook gepaard is gegaan met een duidelijke toename van de arbeidsparticipatie van met name 55-59 jarigen. ${ }^{61}$

\section{Vrouwen}

De aandacht die besteed wordt aan de positie van vrouwen op de arbeidsmarkt is lange tijd voortgekomen uit het feit dat vrouwen veelal minder goede banen hadden en lagere inkomens genoten dan hun mannelijke collega's. De problematiek rond competentieveroudering en scholing vormt echter ook een belangrijke reden om aandacht te blijven besteden aan de positie van vrouwelijke werknemers op de

60. OSA (2004), Trendrapport Aanbod van arbeid 2003, OSA, A205, Tilburg.

61. C. Maas (2003), Arbeidsdeelname ouderen gestegen, ESB, jrg. 88, pp. 527. 
arbeidsmarkt. Een belangrijke reden daarvoor is dat vrouwen duidelijk oververtegenwoordigd zijn in bepaalde beroepen, die zowel fysiek als psychisch bijzonder veeleisend zijn. Typische voorbeelden daarvoor zijn de verzorgende en verplegende beroepen, waarin de risico's van competentieverlies vanwege slijtage groot zijn. Maar ook in andere typische 'vrouwenberoepen' zoals bijvoorbeeld de functie van secretaresse is er vaak sprake van hoge risico's op competentieveroudering: bijvoorbeeld door RSI of door een te hoge werkdruk. In tabel 5.1 wordt dat bevestigd door het gegeven dat het percentage vrouwelijke werknemers dat regelmatig met beeldschermwerk verricht erg hoog is.

Naast de verhoogde risico's op competentieveroudering die voortvloeien uit de oververtegenwoordiging van vrouwen in bepaalde beroepen, zou ook de scholingsparticipatie bij vrouwelijke werknemers tekort kunnen schieten, voor zover vrouwen de arbeidsmarkt tijdelijk verlaten of in deeltijd gaan werken om voor hun kinderen te zorgen. Werkgevers zijn in het algemeen minder geneigd om in hun personeel te investeren bij een groter risico dat de werknemer de baan vroegtijdig verlaat. Door deze zogenaamde "statistische discriminatie" ten aanzien van vrouwelijke werknemers zouden vrouwen minder vaak scholing kunnen volgen dan mannen. De cijfers in tabel 5.1 ondersteunen het bestaan van een dergelijke 'statistische discriminatie' echter niet. Tussen werkende mannen en vrouwen zijn er geen verschillen meer in de mate van scholingsparticipatie.

\section{Etnische minderheden}

Etnische minderheden lopen vooral hoge risico's op competentieveroudering doordat ze vaak werkzaam zijn in lagere beroepen waarin er sprake is van belastende arbeidsomstandigheden. Dit wordt bevestigd door de cijfers in tabel 5.1. Werkenden die behoren tot een etnische minderheidsgroep hebben namelijk relatief vaak te maken met fysiek belastende arbeidsomstandigheden. Daarnaast hebben zij nogal eens een achterstand in de beheersing van de Nederlandse taal, waardoor ze waarschijnlijk bij veranderingen in productietechniek of organisatie meer moeite hebben om zich aan te passen dan hun Nederlandse collega's. Etnische minderheidsgroepen zijn bovendien relatief vaak werkzaam in beroepen waarvoor de werkgelegenheid krimpt.

Hoewel werkenden die behoren tot een etnische minderheidsgroep vaak werkzaam zijn in lagere functies waarin de scholingsdeelname in het algemeen laag is, blijkt de scholingsparticipatie bij de etnische minderheidsgroepen niet achter te blijven bij de scholingsdeelname van de autochtone bevolking. Alleen bij de korte scholingstrajecten is de scholingsdeelname onder etnische minderheden wat lager. Daarentegen participeren werkenden die behoren tot een etnische minderheidsgroep juist relatief veel in langere scholingstrajecten. 


\subsection{Fysieke belasting}

Het spreekt voor zich dat de risico's op competentieveroudering voor de verschillende aandachtsgroepen niet in iedere bedrijfssector gelijk zijn. In deze paragraaf gaan we achtereenvolgens in op de mate waarin jongeren, ouderen, vrouwen en etnische minderheden in de verschillende bedrijfssectoren in hun werk regelmatig fysiek belast worden en kijken we in hoeverre dit verschilt met de risico's voor de gehele werkzame bevolking. We maken daarbij gebruik van dezelfde samengestelde indicator voor fysieke belasting als in paragraaf 2.2. Deze indicator meet de fysieke belasting als de combinatie van kracht zetten, lawaai, en trilling. Voor de achterliggende gegevens wordt verwezen naar de bij dit rapport behorende Statistische Bijlage.

\section{Figuur 5.1}

Regelmatige fysieke belasting naar bedrijfssector, jongeren (15-24 jaar) en totaal, 2001/2002

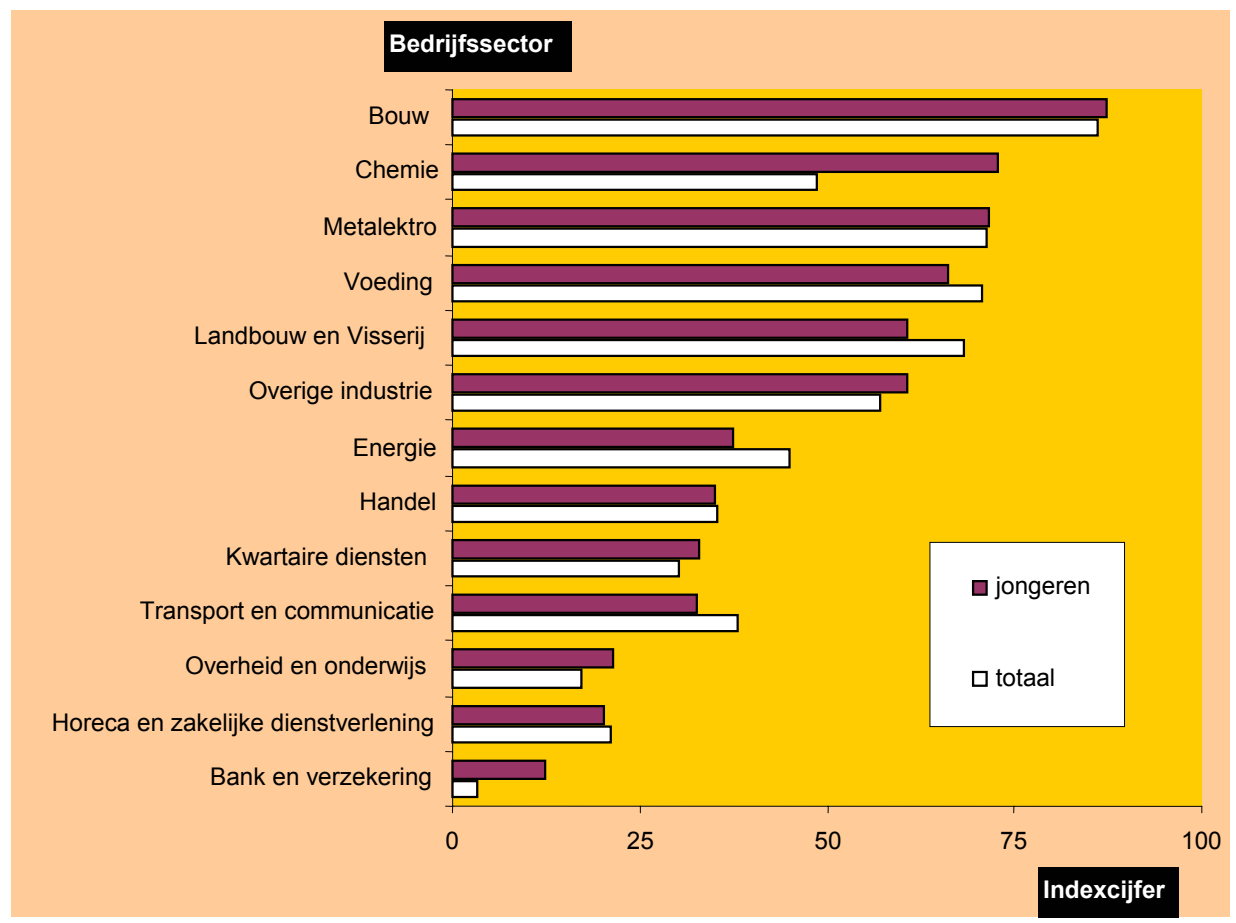

Jongeren

Figuur 5.1 geeft een overzicht van de mate waarin jongere werknemers geconfronteerd worden met belastende arbeidsomstandigheden. In de meeste bedrijfssectoren zijn de verschillen in de fysieke belasting van jongeren en de totale werkzame bevolking klein. In slechts twee van de dertien sectoren is de belasting van jongeren duidelijk hoger dan gemiddeld: in de chemie en in het bank- en verzekeringswezen. Het is opmerkelijk dat in enkele bedrijfssectoren de belasting bij jonge- 
ren lager is dan de gemiddelde belasting voor alle werkenden in de sector. Dit is bijvoorbeeld het geval in de sectoren transport en communicatie en in de landbouw en visserij. Een mogelijke verklaring hiervoor is dat in deze sectoren middelbaar of hoogopgeleide jongeren de betere banen krijgen waarin er minder vaak sprake is van belastende arbeidsomstandigheden. ${ }^{62}$

Figuur 5.2

Regelmatige fysieke belasting naar bedrijfssector, oudere werknemers (54-65 jaar) en totaal, $2001 / 2002$

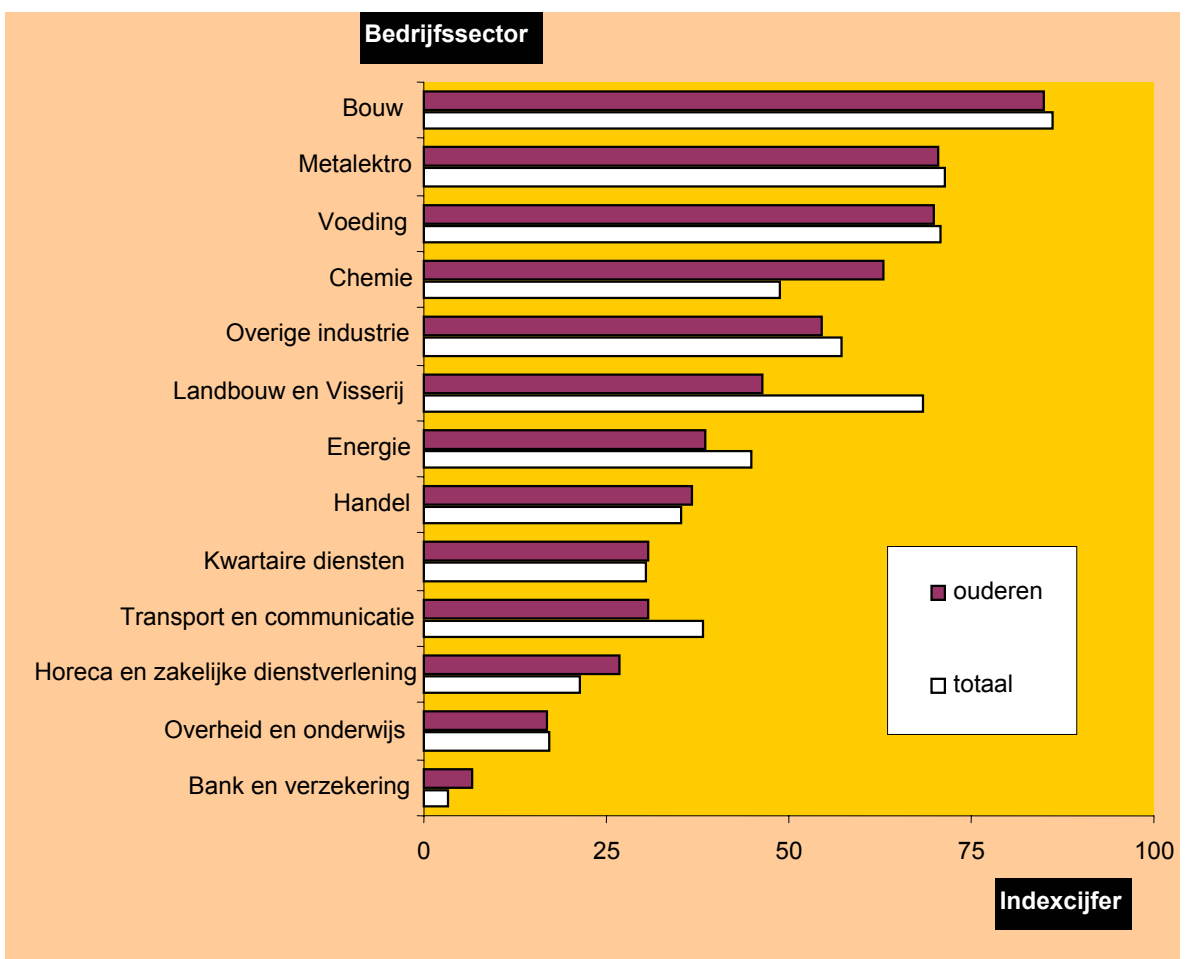

\section{Ouderen}

Figuur 5.2 geeft per bedrijfssector een overzicht van de mate waarin oudere werknemers geconfronteerd worden met fysiek belastende arbeidsomstandigheden in het werk. Ook hier wordt de fysieke belasting van de oudere werknemers afgezet tegen de gemiddelde fysieke belasting in de verschillende bedrijfssectoren.

Oudere werknemers worden in slechts enkele bedrijfssectoren duidelijk meer met fysiek belastend werk geconfronteerd. Alleen in de chemie, de horeca en zakelijke dienstverlening en het bank- en verzekeringswezen is de fysieke belasting voor

62. Een andere mogelijkheid is dat jongeren misschien minder snel aangeven dat bepaalde werkomstandigheden fysiek belastend zijn. 
oudere werknemers hoger in vergelijking met het algemene beeld in die sectoren. Oudere werknemers in de landbouw en visserij verrichten daarentegen minder vaak fysiek belastend werk. Een verklaring hiervoor zou kunnen zijn dat de ouderen in deze sector met name werkzaam zijn in leidinggevende of coördinerende functies waarin de fysieke belasting minder groot is.

Figuur 5.3

Regelmatige fysieke belasting naar bedrijfssector, vrouwen en totaal, 2001/2002

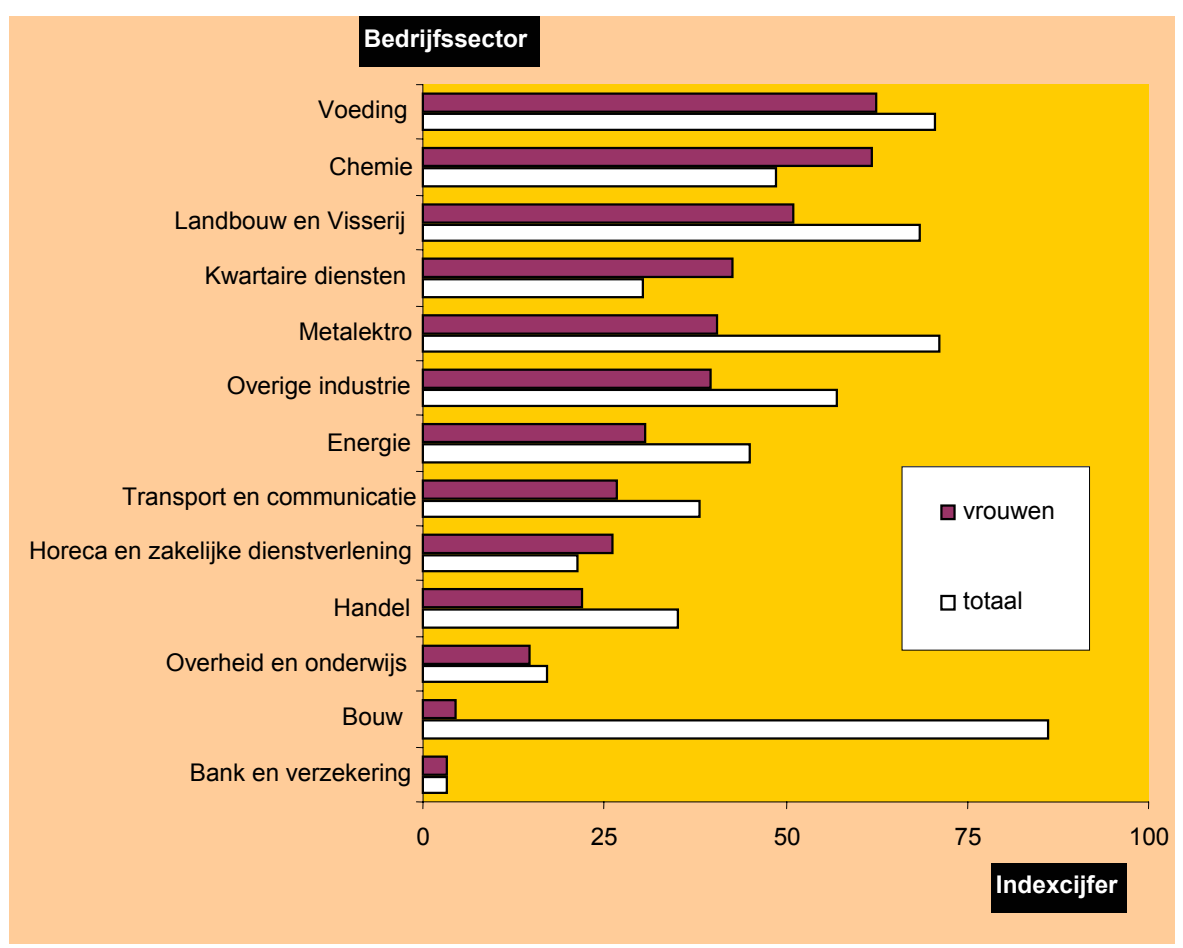

\section{Vrouwen}

Figuur 5.3 geeft een beeld van de fysieke belasting waarmee vrouwelijke werknemers geconfronteerd worden. In de chemie en de kwartaire diensten (gezondheidszorg) zijn de risico's op competentieveroudering vanwege fysiek belastende arbeidsomstandigheden voor vrouwen hoger dan gemiddeld. Ook in de horeca en zakelijke dienstverlening is er, zij het beperkt, sprake van een relatief hogere fysieke belasting voor vrouwelijke werknemers. In de overige sectoren is de fysieke belasting voor vrouwen gelijk aan, of geringer dan het algemene beeld. Wanneer vrouwelijke werknemers minder vaak fysiek belastend werk doen, is dat met name te verklaren door de functies waarin ze werkzaam zijn. Vooral in de bouw en in de industrie worden de sterk fysiek belastende functies immers voor het grootste deel door mannen bekleed. Zoals gezegd, is de chemische industrie op dit punt echter een duidelijke uitzondering. 


\section{Etnische minderheden}

De fysieke belasting van etnische minderheden komt naar voren in figuur 5.4. De chemie is de bedrijfssector waar de fysieke belasting van etnische minderheden het meest uitstijgt boven het algemene beeld. In deze bedrijfssector werkt het overgrote deel van het allochtone personeel onder fysiek belastende arbeidsomstandigheden. Ook in het bank- en verzekeringswezen is de fysieke belasting voor etnische minderheden relatief hoog. In enkele andere sectoren hebben etnische minderheden daarentegen minder vaak te maken met fysiek belastende arbeidsomstandigheden. Dit is bijvoorbeeld het geval in de landbouw en visserij, de bouw, de metalektro- en de energiesector. In de overige sectoren zijn de verschillen tussen allochtone en autochtone werknemers klein.

\section{Figuur 5.4}

Regelmatige fysieke belasting naar bedrijfssector, etnische minderheden en totaal, 2001/2002

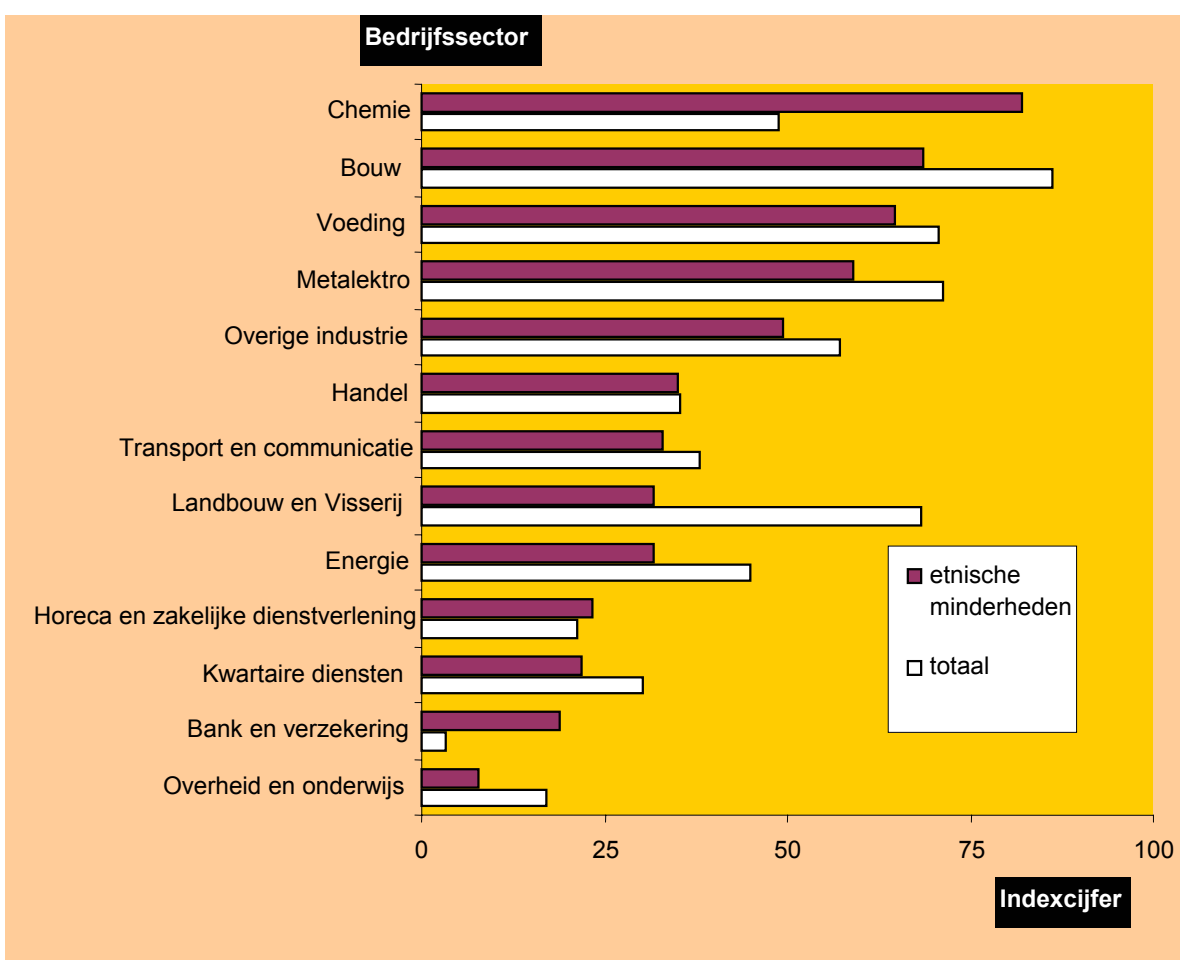

\subsection{Psychische belasting}

In deze paragraaf zal worden ingegaan op de psychische belasting van de onderscheiden aandachtsgroepen in de verschillende bedrijfssectoren door te kijken in hoeverre er regelmatig onder hoge tijdsdruk moet worden gewerkt. 
Jongeren

Zoals figuur 5.5 laat zien werken jongeren in alle bedrijfssectoren minder vaak onder hoge tijdsdruk dan de andere werkenden in de sector. Dat kan op verschillende manieren verklaard worden. Mogelijk hebben jongeren in het begin van hun loopbaan banen waarin een hoge tijdsdruk minder vaak voorkomt dan in de (leidinggevende) banen, die verderop in hun carrière kunnen worden bereikt. Anderzijds kan het ook zo zijn dat jongeren eenvoudig weg minder tijdsdruk ervaren dan ouderen, omdat ze er nog beter mee overweg kunnen.

Figuur 5.5

Regelmatig werken onder hoge tijdsdruk naar bedrijfssector, jongeren en totaal, 2001/2002

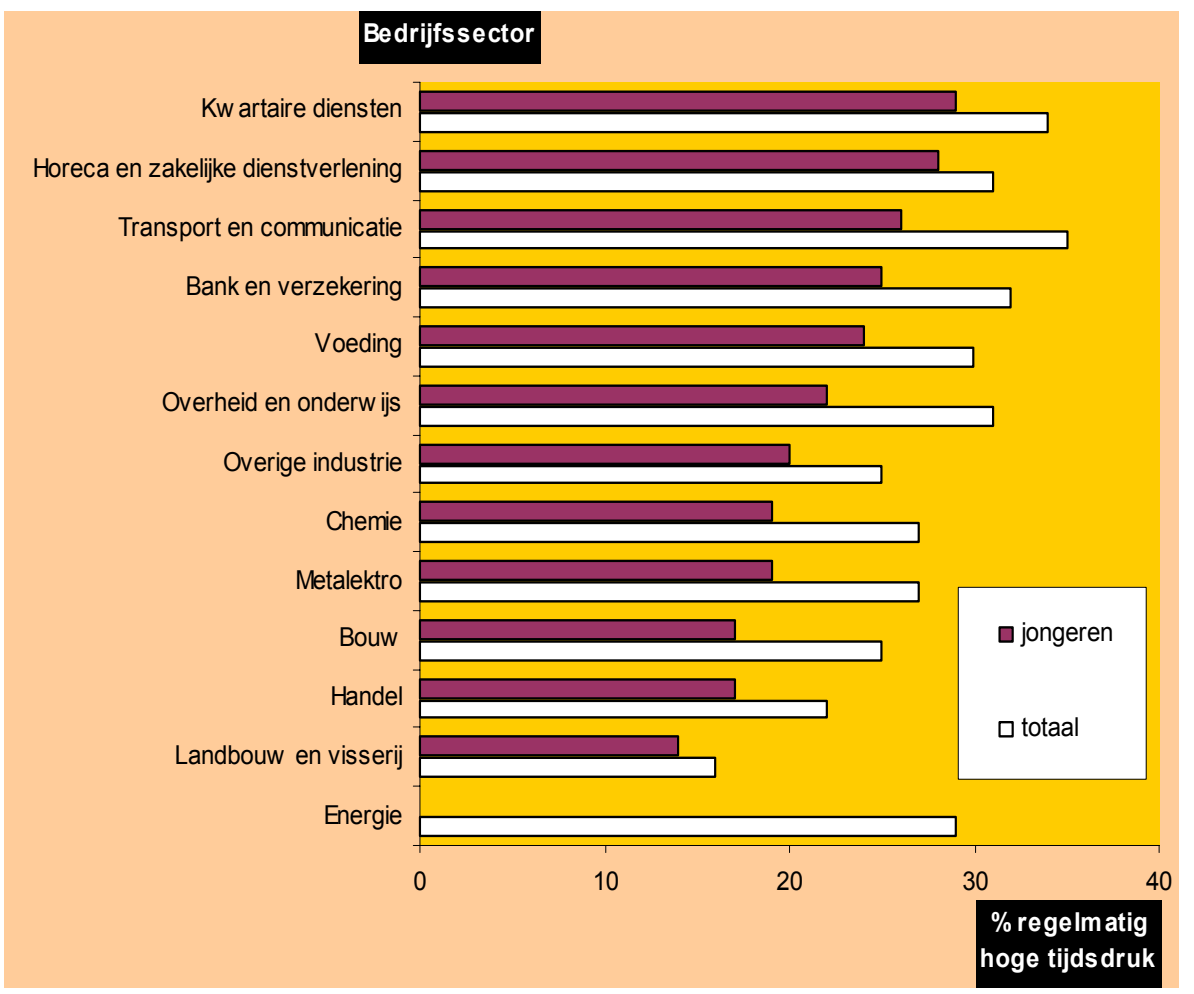

Ouderen

Figuur 5.6 geeft een beeld van de mate waarin oudere werknemers regelmatig onder hoge tijdsdruk moeten werken. In de meeste bedrijfssectoren werken oudere werknemers vaker onder hoge tijdsdruk dan jongeren. Mogelijk komt dit doordat oudere werknemers nogal eens leidinggevende of coördinerende functies hebben die meer tijdsdruk met zich meebrengen. Anderzijds kunnen oudere werknemers eenvoudigweg meer tijdsdruk ervaren dan jongeren, doordat ze vanwege hun leeftijd meer hinder ondervinden van de tijdsdruk waaronder ze moeten werken. Daarbij 
speelt waarschijnlijk ook een rol dat het langdurig werken onder tijdsdruk een cumulerend effect heeft op de psychische belasting.

In de sectoren overheid en onderwijs, de bouw en in het bank en verzekeringswezen is het verschil tussen oudere werknemers en hun jongere collega's het grootst. In drie bedrijfssectoren is er daarentegen sprake van een omgekeerd patroon, waarbij ouderen juist iets minder tijdsdruk ervaren dan jongere werknemers. Het gaat hierbij om de sectoren horeca en zakelijke dienstverlening, de energiesector en de overige industrie.

Al met al is de psychische belasting voor ouderen het hoogst in het bank en verzekerswezen, de kwartaire diensten, de sector transport en communicatie en de sector overheid en onderwijs. In deze sectoren zijn de 'burn-out' risico's voor oudere werkenden dan al het grootst.

Figuur 5.6

Regelmatig werken onder hoge tijdsdruk naar bedrijfssector, ouderen en totaal, 2001/2002

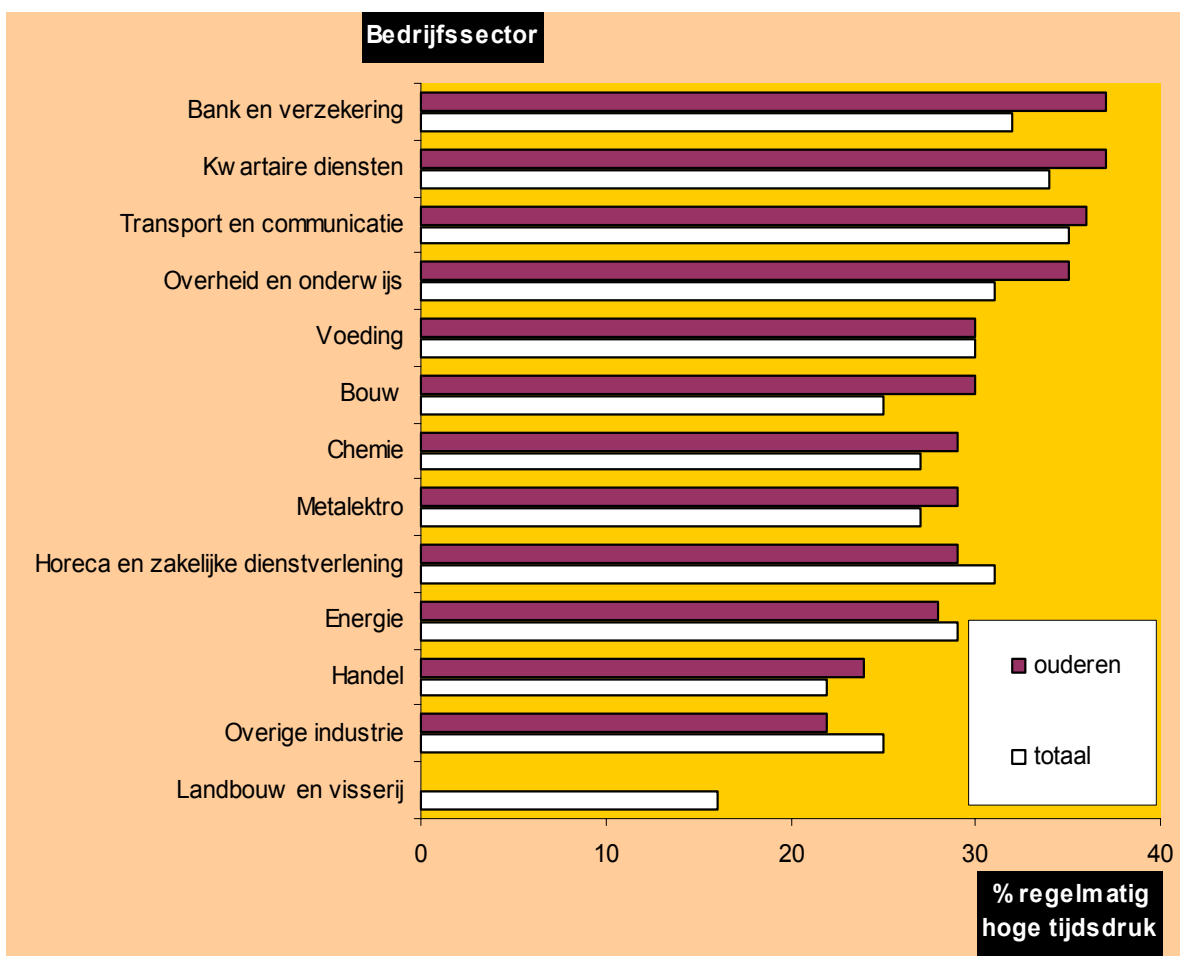




\section{Vrouwen}

Figuur 5.7 laat zien dat in de meeste bedrijfssectoren het regelmatig werken onder hoge tijdsdruk bij vrouwen minder voorkomt dan bij hun mannelijke collega's. ${ }^{63} \mathrm{De}$ enige sector waar dit niet het geval is, is de energiesector, waar vrouwelijke werknemers juist vaker onder een hoge tijdsdruk moeten werken. Dat vrouwen in het algemeen minder vaak onder hoge tijdsdruk werken is hoogstwaarschijnlijk het gevolg van de verschillen in de beroepenstructuur tussen mannen en vrouwen. Vrouwen zijn in het algemeen wat ondervertegenwoordigd in de hogere en leidinggevende beroepen waarin tijdsdruk een belangrijke rol speelt.

\section{Figuur 5.7}

Regelmatig werken onder hoge tijdsdruk naar bedrijfssector, vrouwen en totaal, 2001/2002

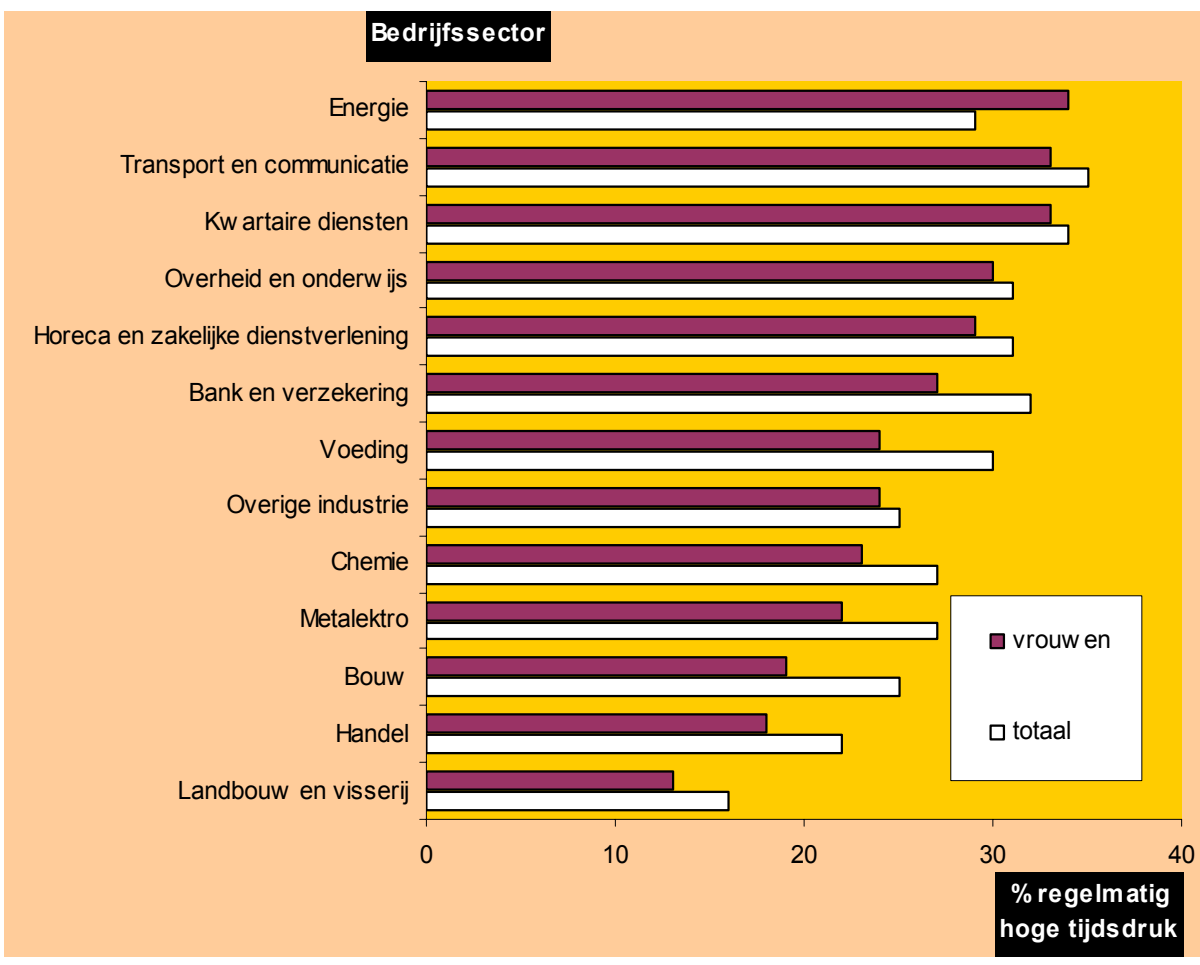

\section{Etnische minderheden}

Figuur 5.8, laat zien dat etnische minderheden in de sectoren voeding, horeca en zakelijke dienstverlening en in het bank- en verzekeringswezen vaker regelmatig onder hoge tijdsdruk werken dan de autochtone werknemers in de desbetreffende bedrijfssector. Ook in de chemie en de handel is dit, zij het in beperkte mate, het

63. Hierbij wordt geen rekening gehouden met de tijdsdruk die samenhangt met het combineren van zorgtaken en part-time werk. 
geval. In de overige sectoren hebben etnische minderheden in hun werk juist minder vaak te maken met een hoge tijdsdruk.

Figuur 5.8

Regelmatig werken onder hoge tijdsdruk naar bedrijfssector, etnische minderheden en totaal, 2001/2002

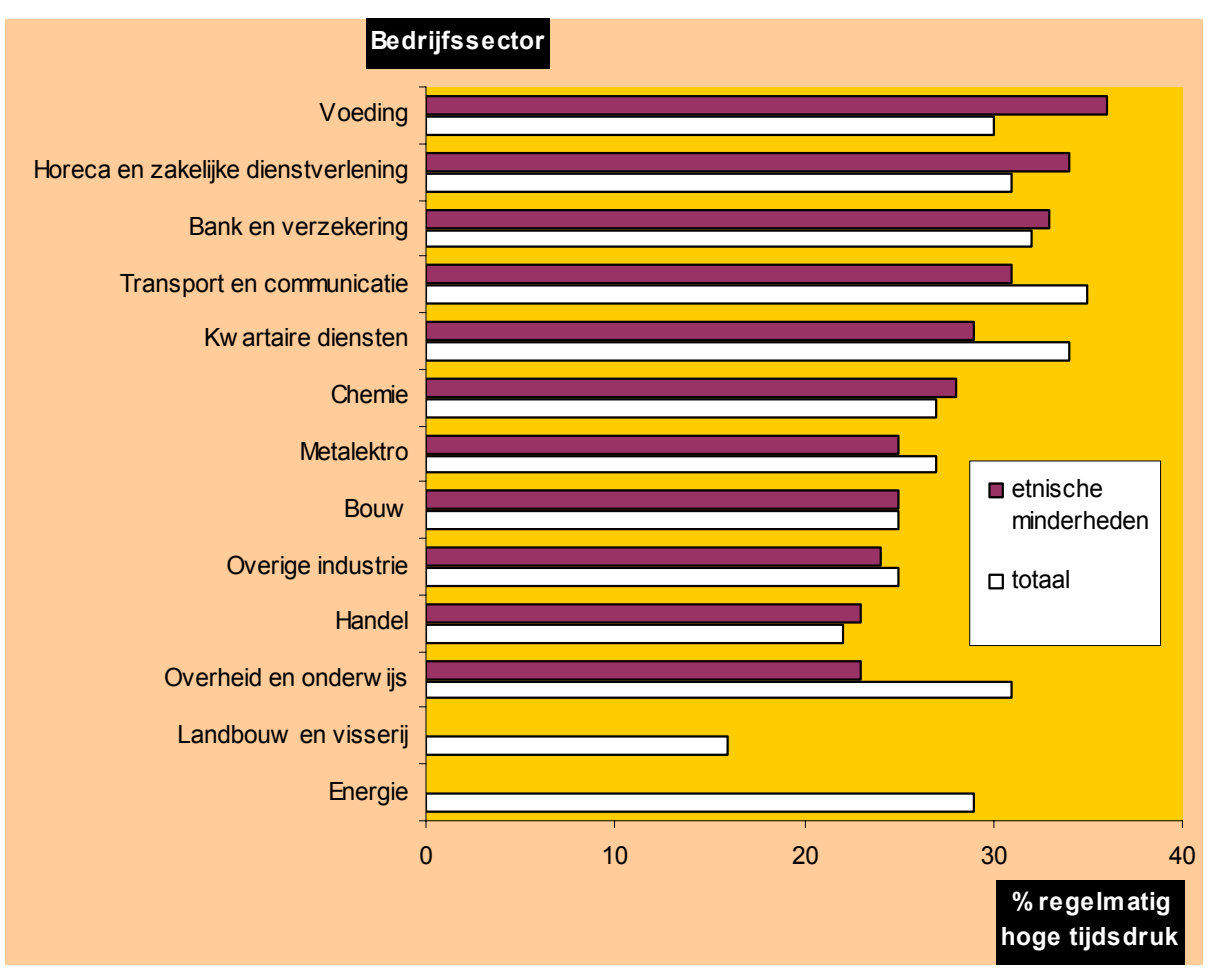

\section{$5.5 \quad$ Beeldschermwerk}

In deze paragraaf kijken we naar de belasting die werkenden ondervinden omdat ze regelmatig beeldschermwerk moeten verrichten.

\section{Jongeren}

In de meeste bedrijfssectoren werken jongeren minder vaak in functies waar ze beeldschermwerk moeten verrichten dan hun oudere collega's. Twee sectoren vormen echter een uitzondering: De bank en verzekeringssector en de sector transport en communicatie. 
Figuur 5.9

Regelmatig beeldschermwerk in bedrijfssectoren, jongeren en totaal, 2001/2002

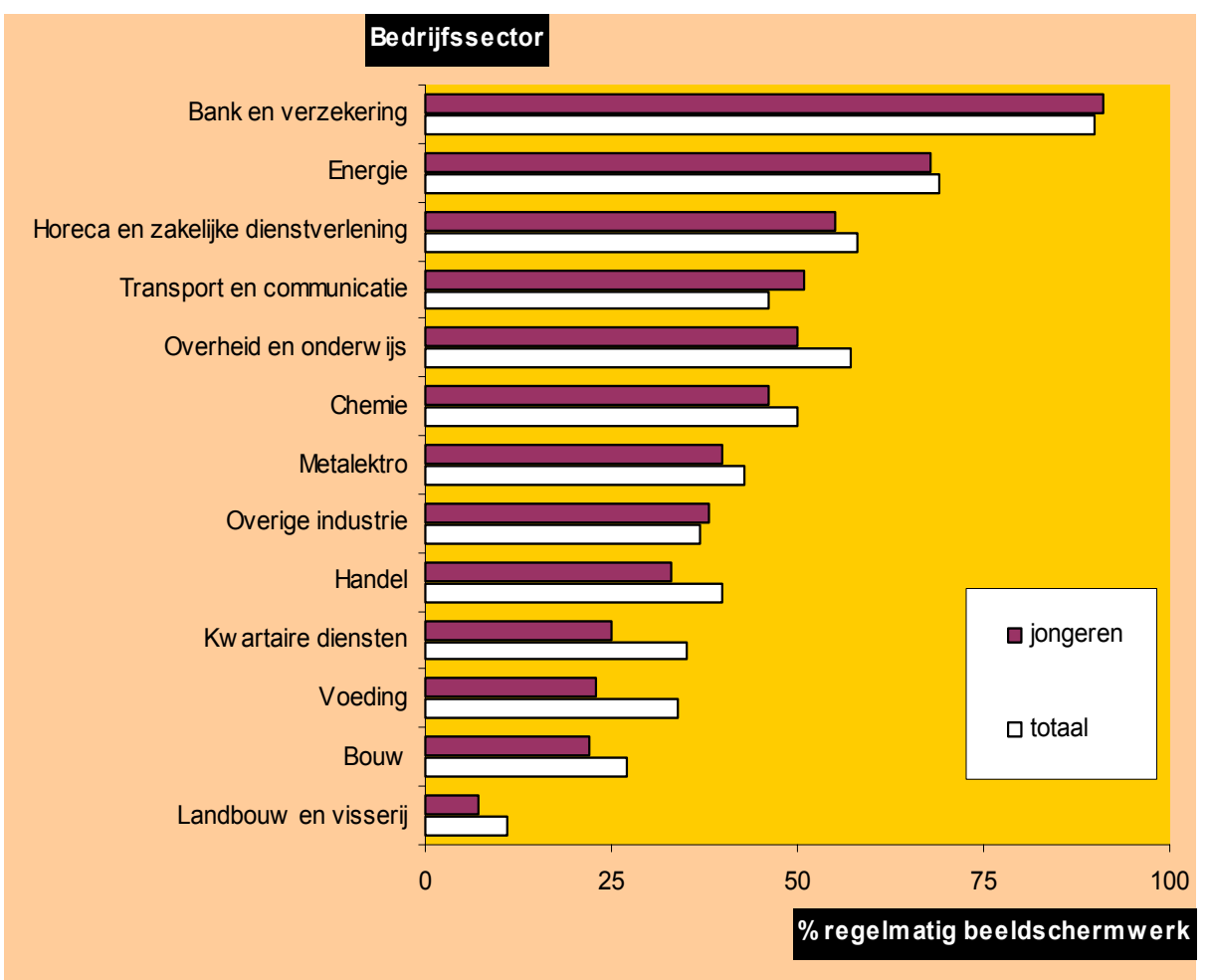

Ouderen

In slechts enkele bedrijfssectoren is de belasting door regelmatig beeldschermwerk voor oudere werknemers bovengemiddeld (zie figuur 5.10). Het gaat dan om de chemie, de kwartaire diensten en de voedingssector. Het is opvallend dat oudere werknemers in de sector transport en communicatie veel minder vaak regelmatig beeldschermwerk verrichten dan de andere werknemers in deze sector. Waarschijnlijk heeft dat te maken met de lagere functies die oudere werknemers in deze sector uitoefenen. De werkenden in de lagere beroepen, zoals bijvoorbeeld chauffeur of conducteurs, worden immers minder met beeldschermwerk geconfronteerd dan de mensen in de hogere beroepen, zoals planners of communicatiespecialisten. 
Figuur 5.10

Regelmatig beeldschermwerk in bedrijfssectoren, ouderen en totaal, 2001/2002

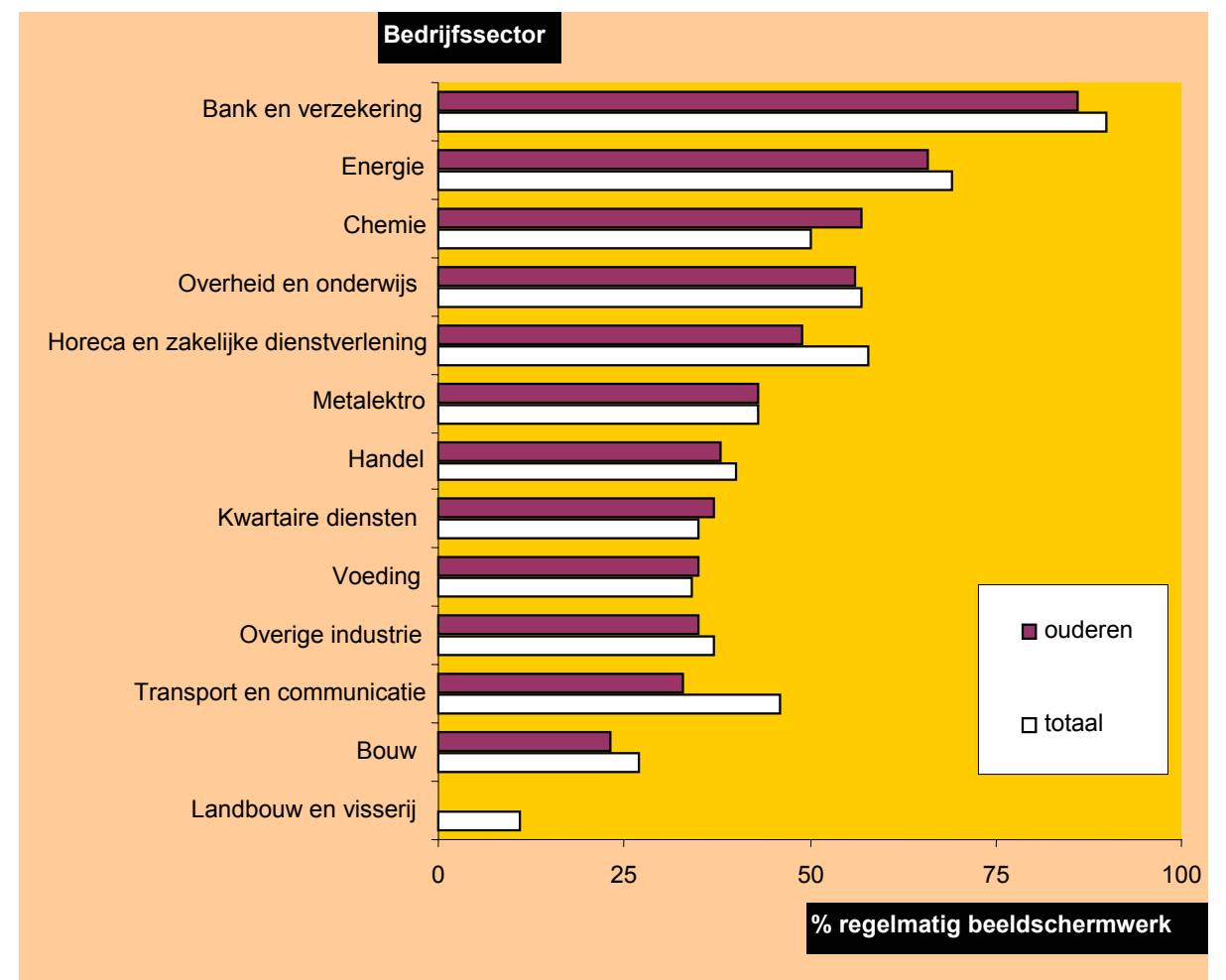

\section{Vrouwen}

Figuur 5.11 geeft een overzicht van de belasting vanwege regelmatig beeldschermwerk bij vrouwen. Het is opvallend dat in de meeste bedrijfssectoren vrouwen vaker beeldschermwerk verrichten dan mannen. In de energiesector, de bouw en de sector transport en communicatie is het verschil tussen mannen en vrouwen het grootst. De achterliggende oorzaak van deze grote verschillen is dat vrouwen in veel bedrijfssectoren secretariële, administratieve of ondersteunende functies uitoefenen, terwijl mannen vaker worden ingezet voor het werk waarbij er minder beeldschermwerk hoeft te worden verricht. Voor vrouwen is het regelmatig verrichten van beeldschermwerk derhalve een belangrijke risicofactor. 
Figuur 5.11

Regelmatig beeldschermwerk in bedrijfssectoren, vrouwen en totaal, 2001/2002

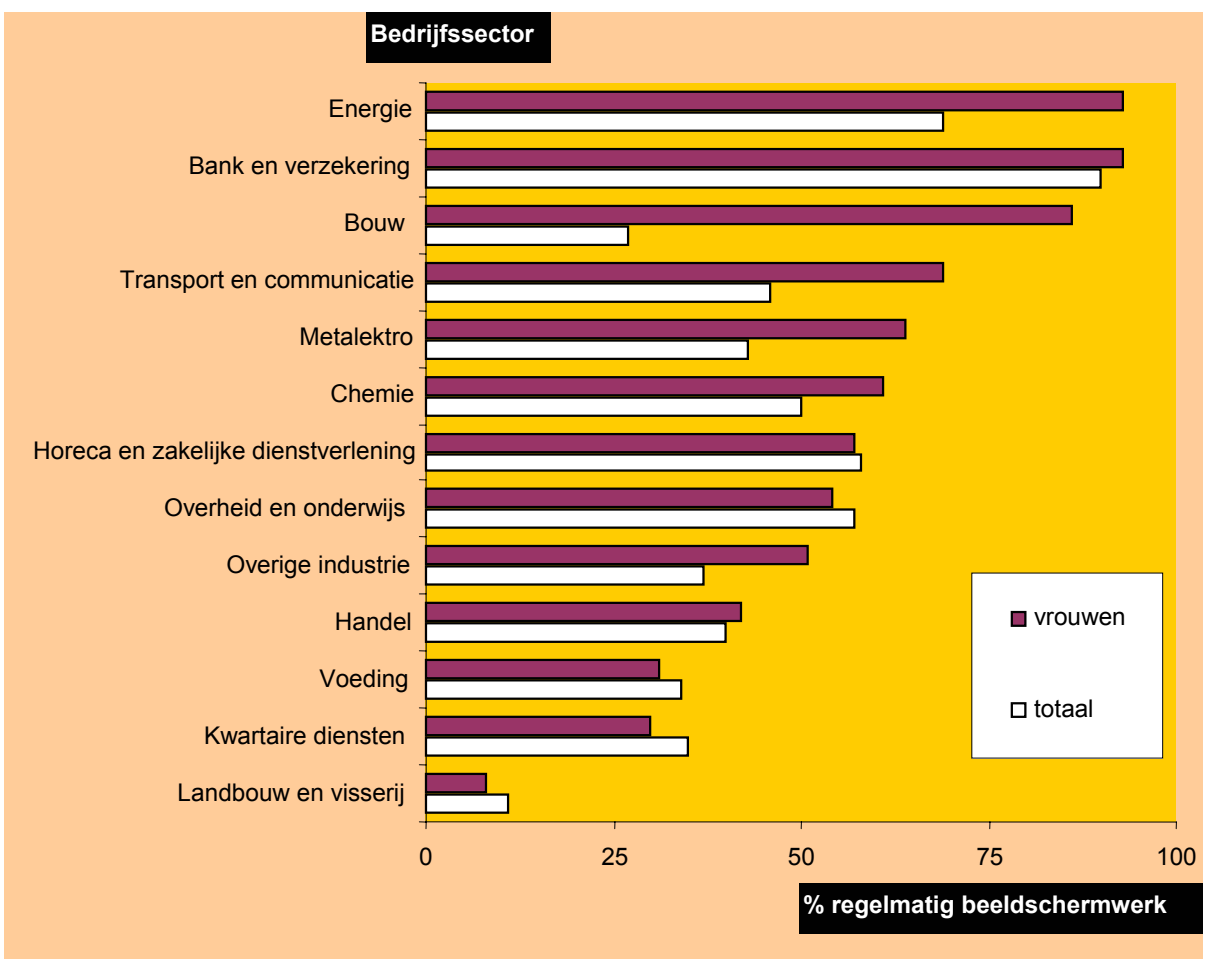

\section{Etnische minderheden}

Werknemers die behoren tot een etnische minderheidsgroep verrichten in veel bedrijfssectoren veel minder vaak beeldschermwerk dan autochtone werkenden. Figuur 5.12 laat zien dat drie sectoren daar een uitzondering op vormen: de sectoren bank en verzekering, overheid en onderwijs en transport en communicatie. Wel moet worden opgemerkt dat in deze sectoren de verschillen in de mate waarin er achter een beeldscherm wordt gewerkt tussen etnische minderheden en de overige werkenden klein zijn.

\subsection{Scholingsparticipatie}

In deze paragraaf gaan we in op de scholingsparticipatie van de onderscheiden aandachtsgroepen in de verschillende bedrijfssectoren. Evenals in hoofdstuk 3 kijken we daarbij naar de deelname van de vier aandachtsgroepen aan zowel kortlopende scholingsactiviteiten (opleidingen die minder dan 6 maanden duren) als langdurige scholingstrajecten (opleidingen die 6 maanden of langer duren). 
Figuur 5.12

Regelmatig beeldschermwerk in bedrijfssectoren, etnische minderheden en totaal, 2001/2002

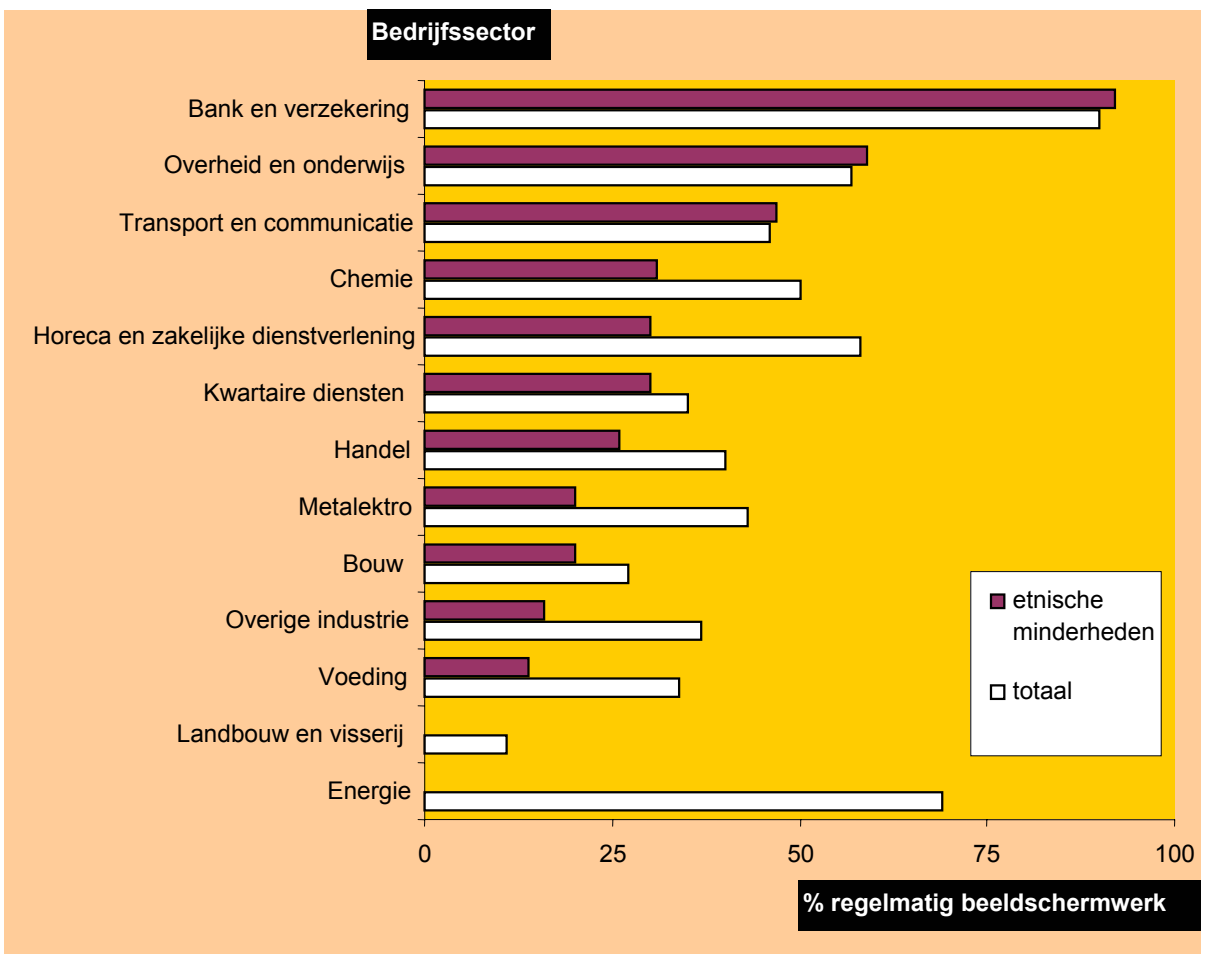

\section{Jongeren}

Figuur 5.13 geeft een overzicht van de scholingsparticipatie van jongeren in vergelijking met het algemene beeld. Twee zaken vallen direct op. Allereerst is de participatie in langdurige scholing bij jongeren in bijna alle bedrijfssectoren circa twee keer zo groot dan de gemiddelde scholingsparticipatie in de sector. Dit kan verklaard worden doordat jongeren aan het begin van hun loopbaan geregeld een langdurig scholingstraject volgen om het werk dat ze hebben onder de knie te krijgen (intredescholing) of op basis van een BBL-contract in dienst zijn.

Bij de kortere scholingstrajecten zijn de verschillen tussen de participatie van jongeren en de gemiddelde scholingsdeelname van de werkenden in de sector veel minder groot. In drie sectoren is de participatie in kortdurende scholing van jongeren relatief hoog: de metalektro, de sector bank en verzekering en de sector overheid en onderwijs. Bedrijfssectoren waar jongeren relatief weinig aan kortdurende scholingstrajecten deelnemen zijn daarentegen de landbouw en visserij, de bouwsector, de sector transport en communicatie en de kwartaire diensten. 
Figuur 5.13

Scholingsparticipatie naar bedrijfssector, jongeren en totaal, 2001/2002

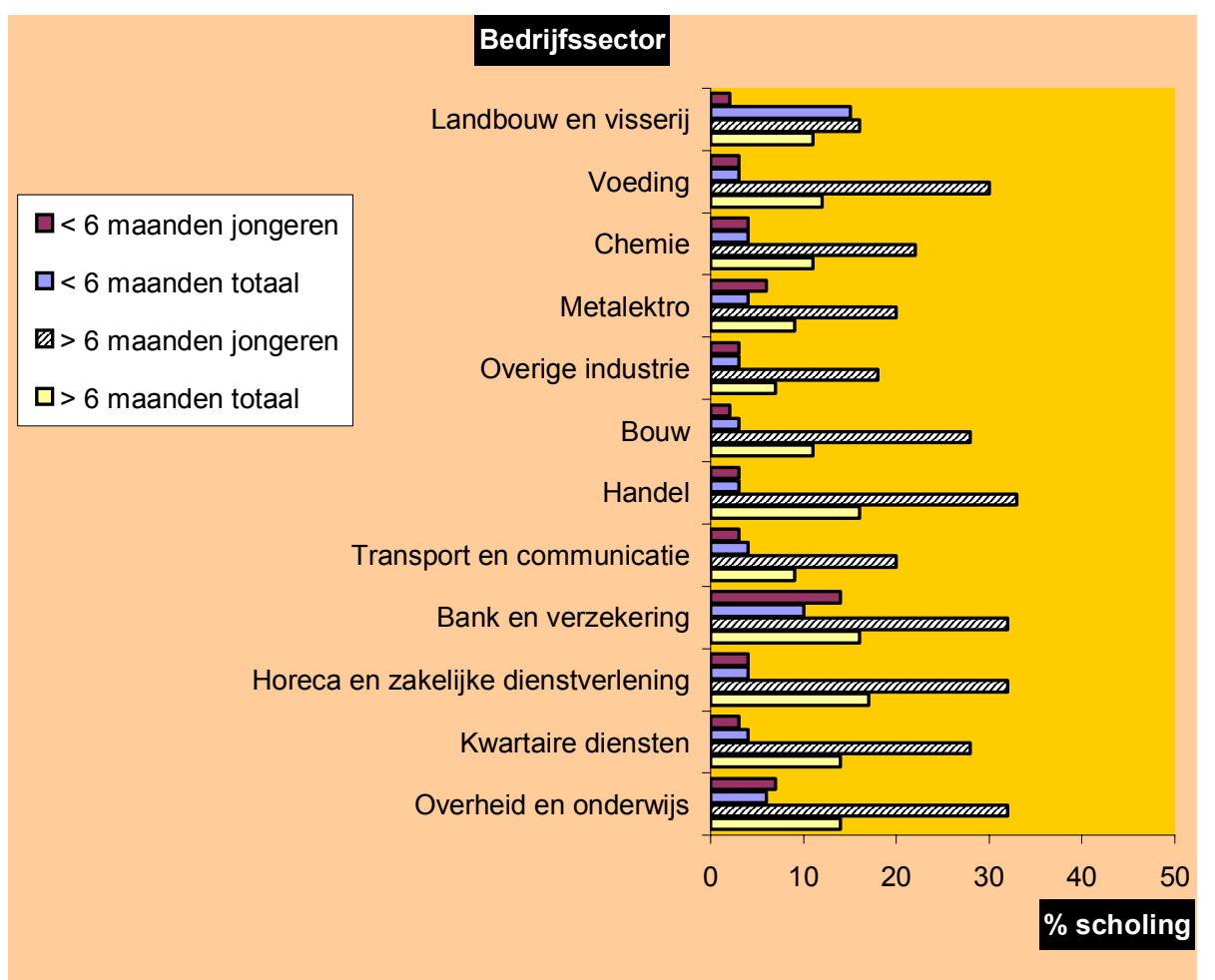

\section{Ouderen}

Figuur 5.14 geeft een overzicht van de scholingsparticipatie van ouderen. Met name de wat langer durende opleidingen worden in alle bedrijfssectoren erg weinig door ouderen gevolgd. In de sector overheid en onderwijs is de deelname van ouderen aan dit soort scholingsactiviteiten overigens nog het hoogst.

Voor de korte scholingstrajecten zijn de verschillen tussen oudere werknemers en de gemiddelde scholingsparticipatie van alle werkenden in de desbetreffende bedrijfssector veel kleiner. In de chemie is de participatie van oudere werknemers aan kortdurende scholingstrajecten zelfs relatief groot. In de overige industrie, de handel, de horeca en zakelijke dienstverlening en de kwartaire diensten ligt de deelname van ouderen aan kortdurende scholingsactiviteiten op het gemiddelde niveau voor de desbetreffende sector. In de overige bedrijfssectoren is de scholingsparticipatie van ouderen relatief laag. 
Figuur 5.14

Scholingsparticipatie naar bedrijfssector, ouderen en totaal, 2001/2002

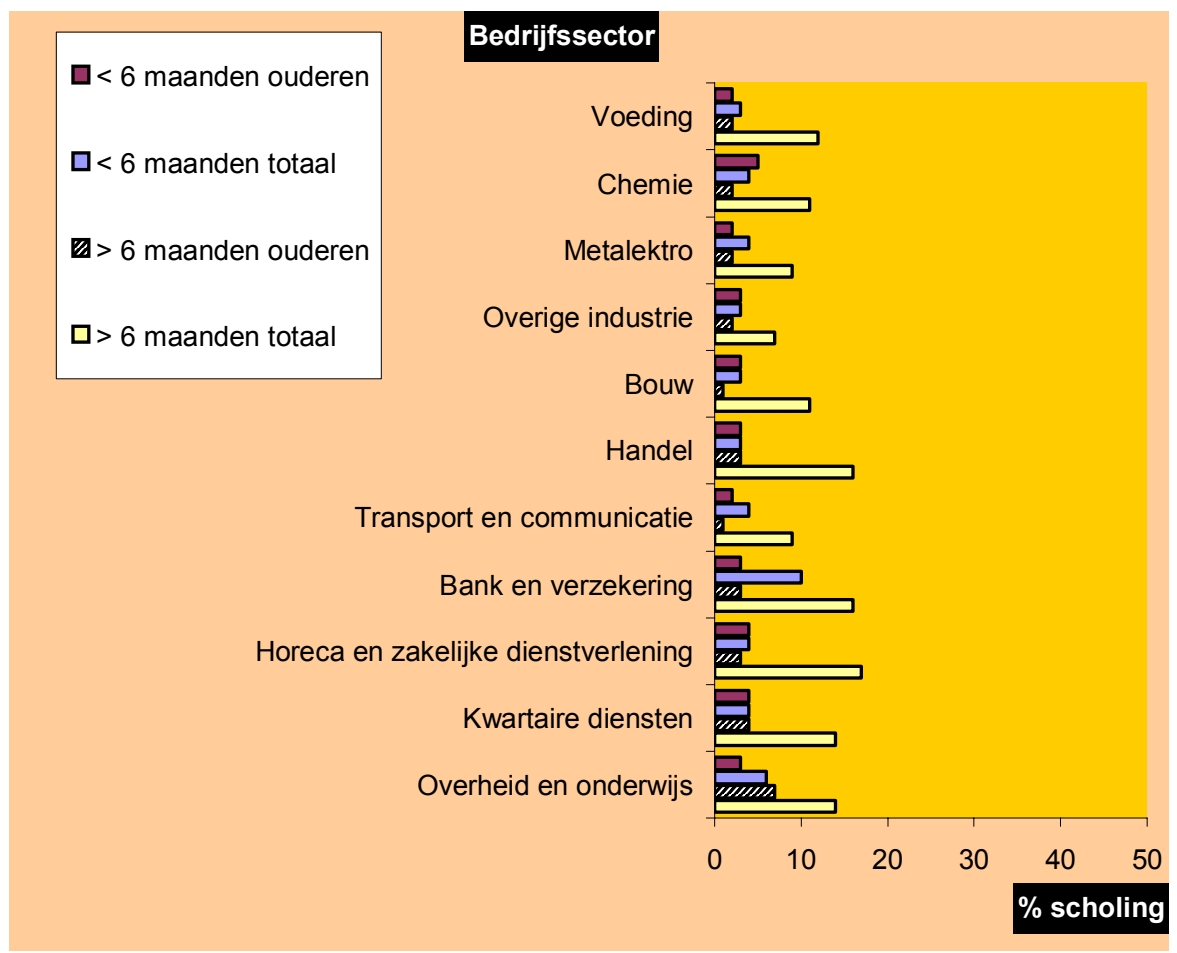

\section{Vrouwen}

Zoals figuur 5.15 laat zien zijn de verschillen in scholingsparticipatie tussen mannen en vrouwen beperkt voor wat betreft de deelname aan langer durende opleidingen. In enkele bedrijfssectoren, zoals bijvoorbeeld de chemie en de sector overheid en onderwijs, is de scholingsparticipatie van vrouwen zelfs relatief groot. Ook bij de deelname aan kortdurende scholingstrajecten zijn de verschillen tussen mannen en vrouwen niet groot. De chemie en het bank- en verzekeringswezen vallen op doordat de vrouwen die in deze sectoren werkzaam zijn relatief vaak aan kortdurende scholing deelnemen. 
Figuur 5.15

Scholingsparticipatie naar bedrijfssector, vrouwen en totaal, 2001/2002

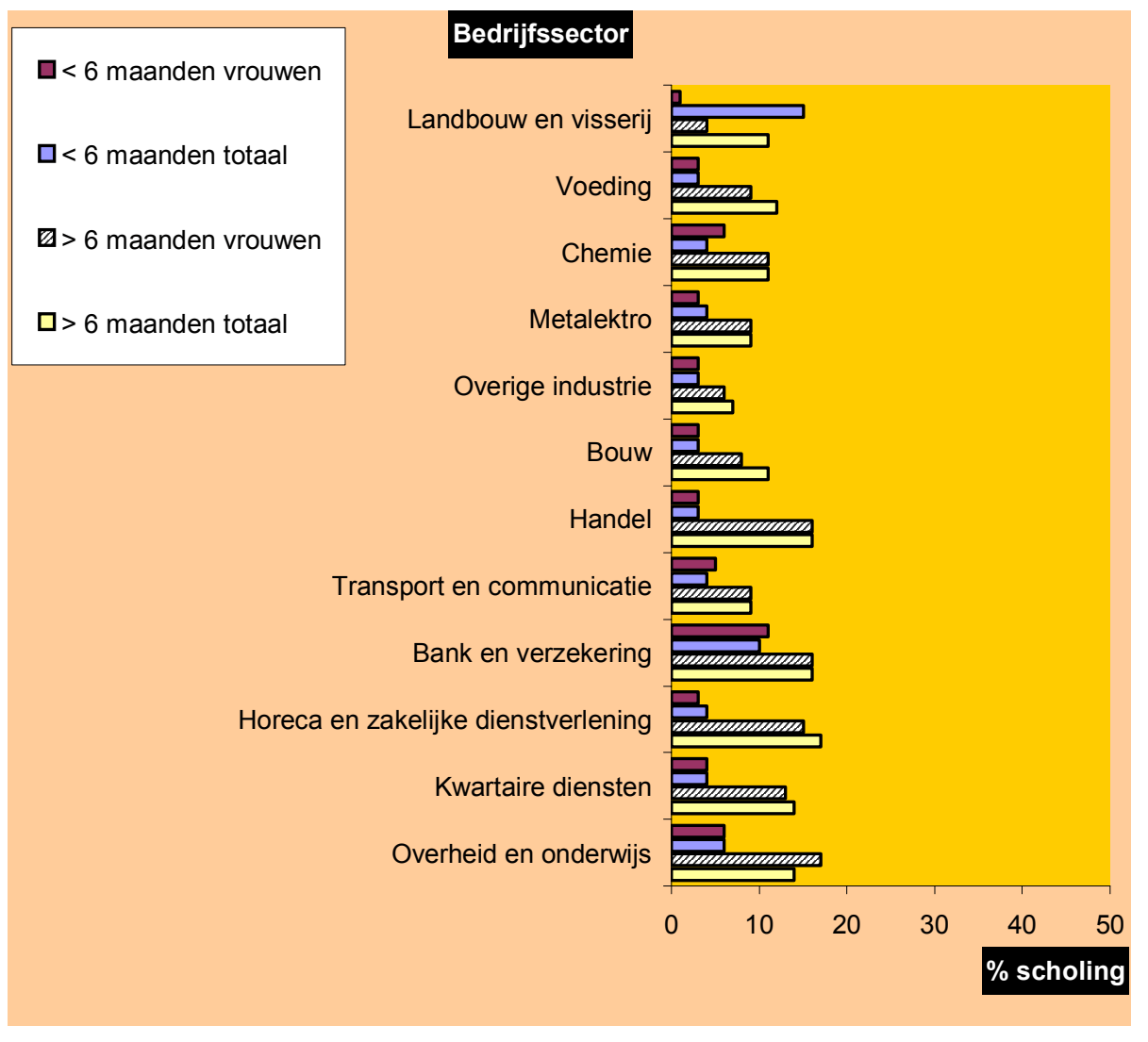

\section{Etnische minderheden}

Helaas zijn er niet voor alle bedrijfssectoren betrouwbare gegevens beschikbaar met betrekking tot de scholingsparticipatie van etnische minderheden. Voor een zevental bedrijfssectoren zijn er, zoals figuur 5.16 laat zien, echter wel cijfers voorhanden. Het blijkt dat in al deze sectoren de werkenden die behoren tot een etnische minderheidsgroep, relatief vaak deelnemen aan langdurige scholingstrajecten. Dit wijst erop dat het volgen van postinitiële scholing voor allochtonen een belangrijke weg is om hun competentieniveau te verbeteren en daarmee hun arbeidsmarktpositie te versterken. Waarschijnlijk gaat het hier voor een belangrijk deel om zogenaamd 'tweedekansonderwijs'. ${ }^{64}$ Voor enkele bedrijfssectoren, zoals de metalektro en de sector overheid en onderwijs, geldt dit ook voor de kortere scholingstrajecten. In de overige sectoren is er sprake van een relatief geringe participatie in kortdurende scholingstrajecten door etnische minderheden.

64. Zie A. de Grip, Van tweedekansonderwijs naar een leven lang leren, Universiteit Maastricht, 2000. 
Figuur 5.16

Scholingsparticipatie naar bedrijfssector, etnische minderheden en totaal, 2001/2002

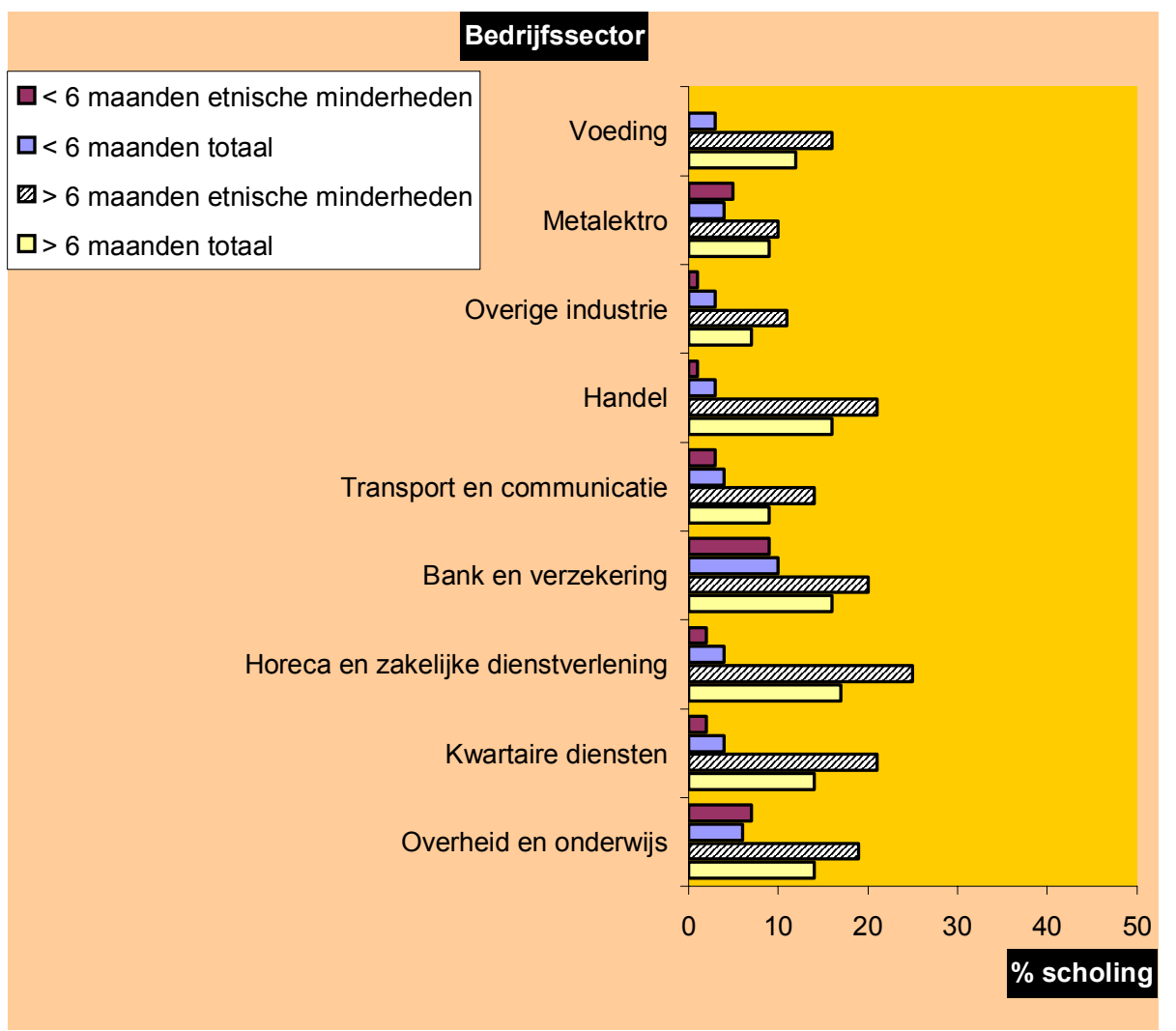

\subsection{Conclusies}

Tabel 5.1 geeft nog eens kort aan in welke bedrijfssectoren er voor de in dit hoofdstuk onderzochte aandachtsgroepen sprake is van een verhoogd risico op competentieveroudering doordat bepaalde risicofactoren een grotere rol spelen en in welke sectoren bepaalde aandachtsgroepen minder dan gemiddeld deelnemen aan scholingsactiviteiten.

De fysieke belasting bij jongeren is groter dan gemiddeld in de chemie, de metalektro, de overige industrie, het bank- en verzekeringswezen, de kwartaire diensten en de sector overheid en onderwijs. Voor ouderen is de fysieke belasting groter dan gemiddeld in de chemie, de handel, de banksector en in de kwartaire diensten. De fysieke belasting voor vrouwen is groter dan gemiddeld in de chemie, het bank en verzekeringswezen, de horeca en zakelijke dienstverlening en de kwartaire diensten. Etnische minderheden hebben in drie sectoren te maken met een bovengemiddelde fysieke belasting: Bank en verzekering, de kwartaire diensten en de chemie. 
Voor wat betreft de psychische belasting vanwege het regelmatig moeten werken onder een hoge tijdsdruk valt met name de positie van oudere werknemers op. In de meeste sectoren is er bij oudere werknemers sprake van een bovengemiddelde psychische belasting. Etnische minderheden hebben alleen in de voedingssector, de chemie de handel en in het bank- en verzekeringswezen te maken met een bovengemiddelde psychische belasting.

Vrouwen verrichten in veel bedrijfssectoren relatief veel beeldschermwerk. Voor oudere werknemers is dat in drie sectoren het geval: de voedingssector, de chemie en de kwartaire diensten. Jongeren komen in de overige industrie, de sector transport en communicatie en in het bank- en verzekeringswezen meer dan gemiddeld regelmatig in aanraking met beeldschermwerk. Voor de groep etnische minderheden is dat het geval in de sector overheid en onderwijs, het bank- en verzekeringswezen en in de transport en communicatiesector.

De deelname aan kortdurende scholingsactiviteiten is voor etnische minderheden die werkzaam zijn in de dienstverlening (transport en communicatie, bank en verzekeringen, horeca en zakelijke dienstverlening en kwartaire diensten) lager dan gemiddeld. Oudere werknemers zijn minder dan gemiddeld betrokken bij kortdurende scholing in de voedingssector, de metalektro, de sector transport en communicatie, het bank- en verzekeringswezen en de sector overheid en onderwijs.

In verreweg de meeste bedrijfssectoren nemen oudere werknemers minder vaak deel aan langdurige scholingstrajecten. Ook vrouwen volgen in enkele sectoren relatief weinig langdurige scholingstrajecten. Dit is het geval in de sector landbouw en visserij, de voeding, de overige industrie, de bouwsector, de horeca en zakelijke dienstverlening en in de kwartaire diensten. Voor etnische minderheden is er alleen in de energiesector sprake van een minder dan gemiddelde scholingsparticipatie. 


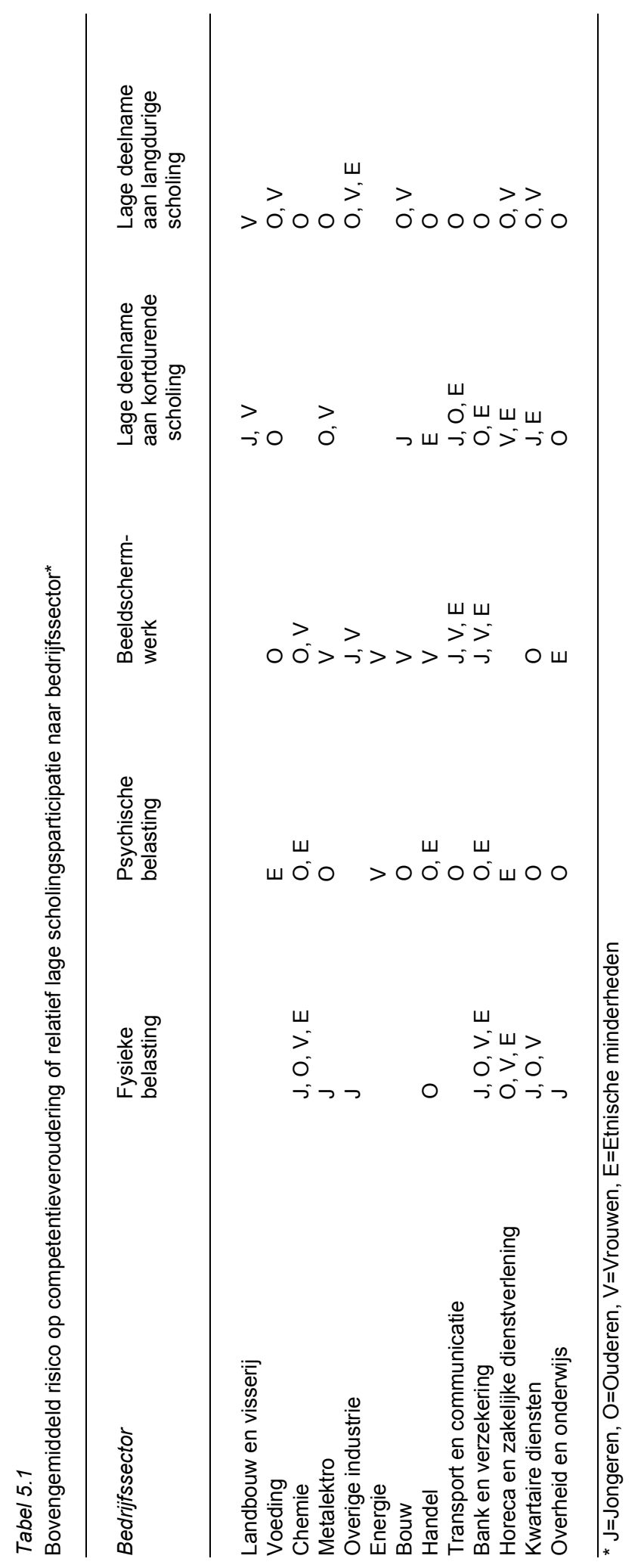





\section{Risicoprofielen en doelgroepen voor het scholingsbeleid}

\subsection{Inleiding}

In voorgaande hoofdstukken is er uitgebreid gekeken naar de risico's die bepaalde groepen werkenden lopen om hun werk te verliezen als gevolg van competentieveroudering en de mate waarin daarop wordt ingespeeld door middel van om- of bijscholing. In dit hoofdstuk zal de informatie over deze risico's en de scholingsparticipatie aan elkaar worden gerelateerd. Allereerst wordt er in paragraaf 6.2 op basis van de informatie uit de vorige hoofdstukken voor iedere bedrijfssector een risicoprofiel (web-diagram) gepresenteerd. Vervolgens wordt in paragraaf 6.3 ingegaan op de groepen werkenden die op een bepaald punt een relatief groot risico lopen op verlies van werk vanwege competentieveroudering en hierop onvoldoende inspelen door het participeren in bij- of omscholingsactiviteiten. We spreken hier van de doelgroepen van het scholingsbeleid. In tegenstelling tot hoofdstuk 5 gaat het hierbij niet om groepen met een bepaald persoonskenmerk, op grond waarvan er problemen verwacht zouden kunnen worden, maar om de beroepsgroepen waarin een deel van de werkenden problemen zal hebben om zich op de arbeidsmarkt te handhaven.

In paragraaf 6.4 wordt er tenslotte gekeken naar de meest kansrijke scholingstrajecten voor deze doelgroepen van het scholingsbeleid. Kansrijke scholingstrajecten worden bepaald door te kijken op welke segmenten van de arbeidsmarkt deze doelgroepen hun kans op behoud van werk zouden kunnen vergroten. Hierbij wordt vanzelfsprekend rekening gehouden met het specifieke risico op competentieveroudering waarmee de doelgroepen worden geconfronteerd. Ook worden er uitspraken gedaan over de aard van de voorgestelde scholingstrajecten. Voor ieder traject zal worden aangegeven of het een sectoroverstijgend, niveauverhogend en/of richtingveranderend scholingtraject betreft.

\subsection{Risicoprofielen}

In deze paragraaf wordt voor alle in dit rapport onderscheiden bedrijfssectoren een risicoprofiel geschetst. Om snel een overzicht te kunnen krijgen van de verschillende risico's op competentieveroudering en de scholingsparticipatie in een bepaalde sector, worden deze profielen als webdiagrammen gepresenteerd. Hierin wordt alle informatie uit de vorige hoofdstukken gecombineerd. Daarbij gaat het om indicatoren voor de:

- fysieke belasting;

- psychische belasting;

- informatisering;

- organisatorische veranderingen;

- werkgelegenheidskrimp;

- tekortschietende effectiviteit van scholingsinspanningen. 
Het essentiële verschil met vorige WSO rapportages is dat de risicoprofielen nu ook informatie bevatten over de effectiviteit van de scholingsinspanningen: Niet alleen de scholingsparticipatie, maar ook de effectiviteit in termen van de opbouw van competenties (zie ook hoofdstuk 4) is in de webdiagrammen verwerkt.

Voor alle facetten in het risicoprofiel is een kwalitatieve typering gegeven van de ernst van het risico op kwalificatieveroudering. Daarbij wordt er gekeken naar drie kwalificaties:

- $\quad$ 'laag' (tussen het middelpunt van het profiel en de binnenste zeshoek);

- ' 'gemiddeld' (tussen de binnenste en de buitenste zeshoeken); en

- 'hoog' (buiten de buitenste zeshoek).

Alle risicofactoren die in de risicoprofielen worden afgebeeld zijn gebaseerd op de centrale indicatoren uit de vorige hoofdstukken. Ze zijn bovendien zo gedefinieerd dat een hoge score betekent dat er een relatief ongunstige situatie bestaat. Op deze wijze wordt het mogelijk om in één oogopslag te zien in hoeverre er zich binnen bepaalde bedrijfssectoren grote risico's voordoen. Het risico op verlies van werk vanwege competentieveroudering is dan namelijk groter naarmate de zeshoek verder naar buiten uitslaat.

In figuur 6.1 worden de risicoprofielen voor de dertien in dit rapport onderscheiden bedrijfssector gepresenteerd.

In de landbouw en visserij vormen met name de hoge fysieke belasting en de verwachte krimpende werkgelegenheid de belangrijkste risicofactoren. $\mathrm{Er}$ is in deze sector veel minder sprake van snelle organisatorische ontwikkelingen en informatisering. Ook de psychische belasting die het werk met zich meebrengt is relatief laag. Wel schiet de effectiviteit van de geleverde scholingsinspanningen tekort.

In de voedingssector is meer dan gemiddeld sprake van fysieke belasting, psychische belasting door tijdsdruk en organisatorische veranderingen. Hoewel werknemers in de voedingsindustrie wel geconfronteerd worden met een krimpende werkgelegenheid en een informatisering van de werkzaamheden, zijn de risico's op competentieveroudering als gevolg daarvan niet bijzonder groot. Wel is ook in deze sector de effectiviteit van de scholingsinspanningen laag.

Werkenden in de chemie en de metalektro worden met vrijwel alle risicofactoren geconfronteerd. Alleen organisatorische veranderingen spelen in deze sectoren geen dominante rol. In de metalektro hebben werkenden vooral te kampen met een sterke werkgelegenheidskrimp en een grote fysieke en psychische belasting. In de chemie is het met name de informatisering van de werkzaamheden die zorgt voor hoge risico's op competentieveroudering. In zowel de chemie als de metalektro is er sprake van een lage effectiviteit van de gevolgde scholing. 
Figuur 6.1

Risicoprofielen voor bedrijfssectoren

Landbouw en visserij

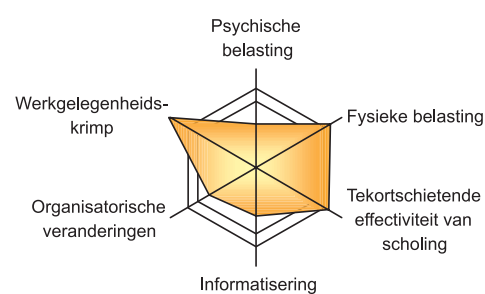

Chemie

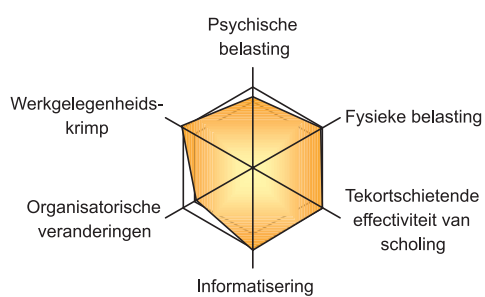

Overige industrie

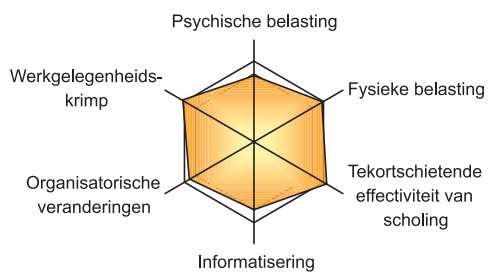

Bouw

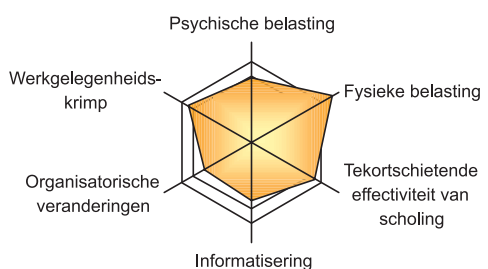

Voeding

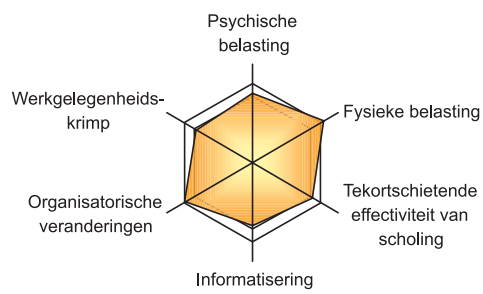

Metalektro

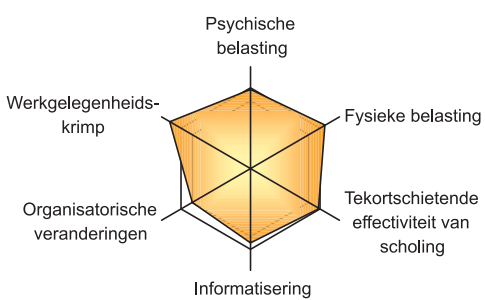

Energie

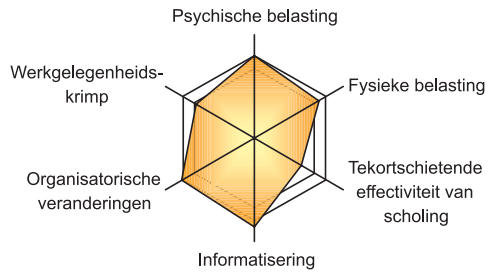

Handel

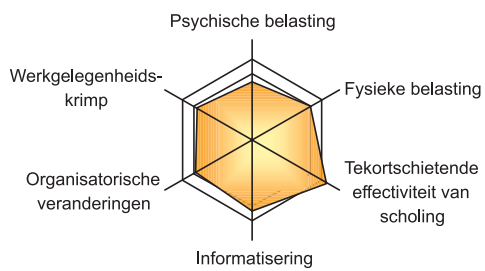


Figuur 6.1 (vervolg)

Risicoprofielen voor bedrijfssectoren

Transport en communicatie

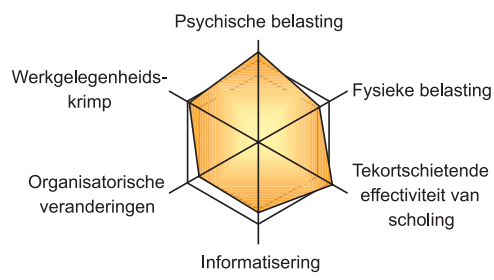

Horeca en zakelijke dienstverlening

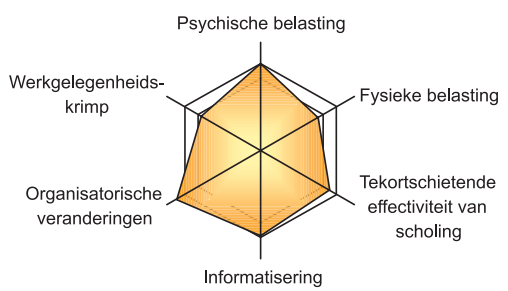

Overheid en onderwijs

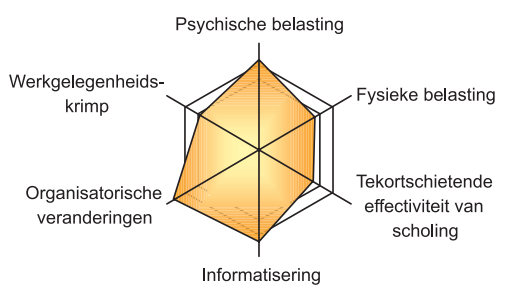

Bank en verzekering

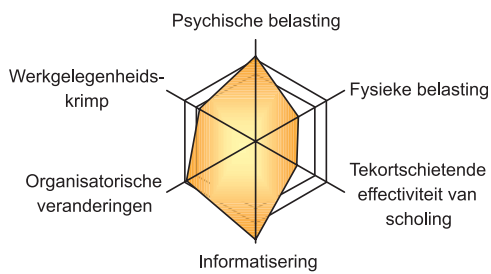

Kwartaire diensten

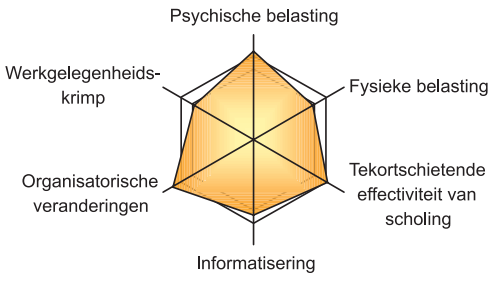

In de overige industrie vormen de sterke werkgelegenheidskrimp en de hoge fysieke belasting belangrijke risico's op verlies van werk vanwege competentieveroudering. Psychische belasting door het werken onder hoge tijdsdruk, organisatorische veranderingen en informatisering zijn minder bedreigend voor de werkenden in deze sector. Wel schiet ook in deze bedrijfssector de mate waarin er wordt geïnvesteerd in effectieve scholing tekort.

Voor werkenden in de sector energie spelen drie van de vijf risicofactoren een belangrijke rol: een hoge psychische belasting door regelmatig werken onder tijdsdruk, veel organisatorische veranderingen, en een hoge mate van informatisering 
van de werkzaamheden. Tegenover deze risico's staan echter wel effectieve scholingsinspanningen. Hierdoor weten de werkenden in de energiesector de risico's die ze lopen op competentieveroudering waarschijnlijk voor een groot deel te neutraliseren.

In de bouwsector vormt met name de fysieke belasting een risicofactor die verlies van werk vanwege competentieveroudering in de hand werkt. Hoewel er in deze sector ook sprake zal zijn van enige werkgelegenheidskrimp vormt dit geen groot risico op verlies van werk. Bovendien is de effectiviteit van de gevolgde scholing redelijk.

In de handel spelen twee van de vijf risicofactoren een rol van betekenis: Informatisering van de werkzaamheden en een hoge fysieke belasting. Ook blijkt de effectiviteit van de scholing in deze sector sterk tekort te schieten. Werkenden in de handel lopen dus een relatief groot risico door informatisering en/of fysieke belasting te maken te krijgen met competentieveroudering doordat hier onvoldoende effectief op wordt ingespeeld.

De sector transport en communicatie valt op doordat met name de psychische belasting erg groot is. Daarnaast is er sprake van een krimpende werkgelegenheid. De overige risicofactoren hebben een gemiddelde invloed. Ook in deze sector schiet de effectiviteit van de scholingsinspanningen tekort.

In het bank en verzekeringswezen is de mate van informatisering van het werk het hoogst van alle bedrijfssectoren. In iets mindere mate is er sprake van een hoge psychische belasting en organisatorische vernieuwingen. Traditiegetrouw is de participatie in effectieve scholingsactiviteiten in het bank- en verzekeringswezen wel behoorlijk groot. Hierdoor zullen werknemers in het bank- en verzekeringswezen in het algemeen relatief goed beschermd zijn tegen de risico's die ze lopen op competentieveroudering die ze lopen.

Werknemers in de horeca en zakelijke dienstverlening lopen met name een risico op competentieveroudering door snelle organisatorische ontwikkelingen, een hoge psychische belasting door tijdsdruk en de informatisering van de werkzaamheden. De mate waarin werknemers in de horeca en zakelijke dienstverlening deelnemen aan scholingsactiviteiten die hierop effectief inspelen is als 'gemiddeld' te karakteriseren.

In de kwartaire diensten vergroten snelle organisatorische veranderingen en een hoge psychische belasting het risico op competentieveroudering. Ook is er sprake van een relatief hogere informatisering van de werkzaamheden. De effectiviteit van de scholingsinspanningen schiet tekort om deze risico's goed te kunnen compenseren.

In de sector overheid en onderwijs worden de werkenden geconfronteerd met drie van de vijf risicofactoren. De werkenden in deze sector hebben te maken met: een relatief grote psychische belasting door het werken onder tijdsdruk, organisatorische 
veranderingen en een aanzienlijke informatisering van de werkzaamheden. Wat betreft de scholingsparticipatie is het beeld redelijk positief. In het algemeen wordt er bij de overheid en de onderwijssector behoorlijk in effectieve scholingsactiviteiten geparticipeerd.

\subsection{Doelgroepen voor scholingsbeleid}

Zoals uit hoofdstuk 2 naar voren kwam, lopen veel werkenden op bepaalde punten aanzienlijke risico's op verlies van werk vanwege competentieveroudering. Dit maakt het belangrijk om hier adequaat op in te spelen door het tijdig volgen van de bij- of omscholing die nodig is om iemands arbeidsmarktpositie op de middellange termijn te kunnen handhaven. Een aantal beroepsgroepen loopt echter momenteel relatief grote risico's op verlies van werk vanwege competentieveroudering, mede omdat hier onvoldoende op wordt ingespeeld door het volgen van de gewenste bij- of omscholing. Deze beroepsgroepen bestempelen we in deze paragraaf als de 'doelgroepen van het scholingsbeleid.'

Tabel 6.1 geeft een overzicht van deze doelgroepen. De doelgroepen zijn bepaald door de risicogroepen die aan het einde van hoofdstuk 2 aan de orde kwamen te combineren met de informatie over de scholingsparticipatie uit hoofdstuk 3 . Een groep werkenden wordt alleen als doelgroep voor het scholingsbeleid getypeerd wanneer de participatie in zowel kortdurende als langdurige scholingstrajecten (erg) laag is, of als de participatie aan één van beide (erg) laag is en de deelname aan de andere scholingsactiviteiten op een gemiddeld niveau ligt. In de laatste kolom van tabel 6.1 wordt voor iedere doelgroep voor het scholingsbeleid aangegeven welke risicofactor(en) ervoor zorgen dat de werkenden in die beroepsgroep een hoog risico lopen om hun werk te verliezen.

Vanwege de teruglopende werkgelegenheid in de agrarische sector worden agrarische bedrijfshoofden en landbouwmachinebestuurders en vissers bedreigd met verlies van werk vanwege competentieveroudering. Er vindt te weinig omscholing plaats om dit risico op verlies van werk te beperken.

Bankwerkers en lassers en metaalarbeiders in de metalektro vormen een doelgroep voor het scholingsbeleid vanwege de sterk fysiek belastende arbeidsomstandigheden waarmee ze in hun werk te maken hebben. Voor de managers en de commercieel medewerkers die in deze sector werkzaam zijn, is het risico op verlies van werk vanwege competentieveroudering daarentegen hoog vanwege de hoge psychische belasting doordat ze regelmatig onder een hoge tijdsdruk moeten werken. Werkbouwkundigen en hoofden technische dienst lopen een verhoogd risico op baanverlies door de krimpende werkgelegenheid. De werkenden in deze beroepsgroepen volgen te weinig scholing om het risico vanwege competentieveroudering het werk te verliezen te beperken.

Ook bouwvakkers zijn een belangrijke doelgroep voor het scholingsbeleid. Hierbij gaat het naast de bouwvakkers die werkzaam zijn in de bouwsector, ook om de 
bouwvakkers die in de metelektro werken. Zij worden met name bedreigd met competentieveroudering vanwege de hoge fysieke belasting die het werk met zich meebrengt. Zowel in de bouwsector als in de metalektro zijn de bestaande scholingsinspanningen onvoldoende om deze risico's te beperken. Om dezelfde redenen lopen ook weg- en waterbouwkundig arbeiders in de bouwsector hoge risico's op baanverlies. Productiemedewerkers in de bouwsector lopen een verhoogd risico op verlies van werk door een krimpende werkgelegenheid.

Tabel 6.1

Doelgroepen voor het scholingsbeleid en risicofactoren

\begin{tabular}{|c|c|c|}
\hline Bedrijfssector & Doelgroepen: & risicofactor(en) \\
\hline $\begin{array}{l}\text { Landbouw en } \\
\text { visserij }\end{array}$ & $\begin{array}{l}\text { Agrarische bedrijfshoofden } \\
\text { Landbouwmachinebestuurders en vissers }\end{array}$ & $\begin{array}{l}\text { krimpende } \\
\text { werkgelegenheid } \\
\text { krimpende } \\
\text { werkgelegenheid }\end{array}$ \\
\hline Voedingsindustrie & Mechanische operators & $\begin{array}{l}\text { krimpende } \\
\text { werkgelegenheid }\end{array}$ \\
\hline Metalektro & $\begin{array}{l}\text { Bouwvakkers } \\
\text { Metaalarbeiders } \\
\text { Bankwerkers en lassers } \\
\text { Managers } \\
\text { Commercieel medewerkers } \\
\text { Werktuigbouwkundig ontwerpers en hoofden } \\
\text { technische dienst }\end{array}$ & $\begin{array}{l}\text { fysieke belasting } \\
\text { fysieke belasting } \\
\text { fysieke belasting } \\
\text { tijdsdruk } \\
\text { tijdsdruk } \\
\text { krimpende } \\
\text { werkgelegenheid }\end{array}$ \\
\hline Overige industrie & $\begin{array}{l}\text { Journalisten } \\
\text { Grafische vakkrachten }\end{array}$ & $\begin{array}{l}\text { RSI } \\
\text { krimpende } \\
\text { werkgelegenheid }\end{array}$ \\
\hline Bouw & $\begin{array}{l}\text { Bouwvakkers } \\
\text { Weg- en waterbouwkundige arbeiders } \\
\text { Productiemedewerkers }\end{array}$ & $\begin{array}{l}\text { fysieke belasting } \\
\text { fysieke belasting } \\
\text { krimpende } \\
\text { werkgelegenheid }\end{array}$ \\
\hline Handel & Technisch-commercieel employés & $\begin{array}{l}\text { krimpende } \\
\text { werkgelegenheid }\end{array}$ \\
\hline $\begin{array}{l}\text { Transport en } \\
\text { communicatie }\end{array}$ & $\begin{array}{l}\text { Vliegers, scheepskapiteins en } \\
\text { leidinggevenden in het transport } \\
\text { Schippers en conducteurs }\end{array}$ & $\begin{array}{l}\text { tijdsdruk } \\
\text { krimpende } \\
\text { werkgelegenheid }\end{array}$ \\
\hline $\begin{array}{l}\text { Horeca en zakelijke } \\
\text { dienstverlening }\end{array}$ & Organisatiedeskundigen & tijdsdruk \\
\hline Kwartaire diensten & $\begin{array}{l}\text { Journalisten } \\
\text { Kunstenaars }\end{array}$ & $\begin{array}{l}\text { tijdsdruk, agressief } \\
\text { gedrag van klanten } \\
\text { tijdsdruk, agressief } \\
\text { gedrag van klanten }\end{array}$ \\
\hline
\end{tabular}

Journalisten zijn in twee bedrijfssectoren een doelgroep voor het scholingbeleid. In de overige industrie, waartoe de grafische industrie gerekend wordt, hebben journalisten regelmatig te maken met beeldschermwerk en een hoge tijdsdruk, wat resulteert in een verhoogd risico op RSI. In de kwartaire diensten is er naast een hoge tijdsdruk bovendien relatief vaak sprake van agressief gedrag van klanten. De 
huidige scholingsparticipatie van journalisten is onvoldoende om het risico dat men als gevolg hiervoor op een gegeven moment het werk niet meer aan kan te beperken.

In de handel lopen technisch-commercieel employés een verhoogd risico op verlies van werk vanwege een krimpende werkgelegenheid. De huidige scholingsinspanningen zijn onvoldoende om dit risico te beperken.

In de sector transport en communicatie lopen schippers en conducteurs een verhoogd risico op verlies van werk vanwege een krimpende werkgelegenheid. De beroepsgroep vliegers, scheepskapiteins en leidinggevenden in het transport lopen daarentegen het risico op verlies van werk vanwege de hoge tijdsdruk waarmee ze in hun werk te maken krijgen en de geringe participatie in scholingsactiviteiten die de risico's op verlies van werk kunnen beperken. Hetzelfde geldt voor de organisatiedeskundigen die werkzaam zijn in de zakelijke dienstverlening.

Kunstenaars die werkzaam zijn in de sector kwartaire diensten vormen de laatste doelgroep voor het scholingsbeleid. Zij zijn onvoldoende betrokken bij scholingsactiviteiten om de risico's op verlies van werk als gevolg van tijdsdruk en agressief gedrag van klanten te beperken. Het gaat hier met name om regisseurs, hoofden van grafische ontwerpafdelingen, choreografen en zangers, die vanwege tijdsdruk en agressief gedrag van klanten een relatief hoog risico op competentieveroudering lopen.

\subsection{Kansrijke scholingstrajecten}

In deze paragraaf zal worden ingegaan op de scholingstrajecten die de hierboven genoemde doelgroepen van het scholingsbeleid perspectief kunnen bieden op behoud van werk.

Tabel 6.2

Meest kansrijke scholingstrajecten voor de doelgroepen voor het scholingsbeleid

Doelgroep Soort scholingstraject uitwijkberoep

Landbouw en visserij

Agrarische bedrijfshoofden

Landbouwmachinebestuurders en vissers

Voedingsindustrie

Mechanische operators

Metalektro

Bouwvakkers

Bankwerkers en lassers
Sectoroverstijgend, Richtingveranderend

Sectoroverstijgend, Richtingveranderend

Sectoroverstijgend, Richtingveranderend

Sectoroverstijgend, Richtingveranderend

Sectoroverstijgend, Richtingveranderend bedrijfshoofden horeca in de horeca en zakelijke dienstverlening Monteurs in de sector handel

Monteurs in de sector handel

Economisch administratief beroep op laag niveau in de handel of zakelijke dienstverling Elektromonteurs in de sector energie 
Tabel 6.2 (vervolg)

Meest kansrijke scholingstrajecten voor de doelgroepen voor het scholingsbeleid

\begin{tabular}{|c|c|c|}
\hline Doelgroep & Soort scholingstraject & uitwijkberoep \\
\hline Metaalarbeiders & $\begin{array}{l}\text { Sectoroverstijgend, } \\
\text { Richtingveranderend }\end{array}$ & Elektromonteurs in de sector energie \\
\hline Managers & Sectoroverstijgend & $\begin{array}{l}\text { Managers in het bank en } \\
\text { verzekeringswezen }\end{array}$ \\
\hline Commercieel medewerkers & Sectoroverstijgend & $\begin{array}{l}\text { Commercieel medewerkers in het bank en } \\
\text { verzekeringswezen }\end{array}$ \\
\hline $\begin{array}{l}\text { Werktuigbouwkundig } \\
\text { ontwerpers en hoofden } \\
\text { technische dienst }\end{array}$ & $\begin{array}{l}\text { Sectoroverstijgend, } \\
\text { Richtingveranderend }\end{array}$ & $\begin{array}{l}\text { Openbare orde en veiligheidsberoep in de } \\
\text { sector horeca en zakelijke dienstverlening }\end{array}$ \\
\hline \multicolumn{3}{|l|}{ Overige industrie } \\
\hline Journalisten & $\begin{array}{l}\text { Sectoroverstijgend, } \\
\text { Richtingveranderend }\end{array}$ & $\begin{array}{l}\text { Medewerkers sociaal-cultureel werk en } \\
\text { personeel en arbeid in de kwartaire } \\
\text { diensten of de sector overheid en } \\
\text { onderwijs }\end{array}$ \\
\hline Grafische vakkrachten & $\begin{array}{l}\text { Sectoroverstijgend, } \\
\text { Richtingveranderend }\end{array}$ & $\begin{array}{l}\text { Informaticaberoep in sector overheid en } \\
\text { onderwijs }\end{array}$ \\
\hline \multicolumn{3}{|r|}{ 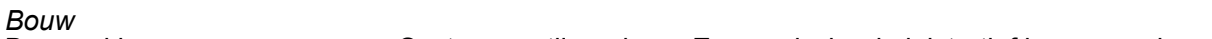 } \\
\hline Bouwvakkers & $\begin{array}{l}\text { Sectoroverstijgend, } \\
\text { Richtingveranderend }\end{array}$ & $\begin{array}{l}\text { Economisch administratief beroep op laag } \\
\text { niveau in de handel of zakelijke } \\
\text { dienstverling }\end{array}$ \\
\hline Productiemedewerkers & $\begin{array}{l}\text { Niveauverhogend, } \\
\text { Sectoroverstijgend }\end{array}$ & Monteurs in de sector handel \\
\hline \multicolumn{3}{|l|}{ Handel } \\
\hline $\begin{array}{l}\text { Technisch commercieel } \\
\text { employés }\end{array}$ & Sectoroverstijgend & $\begin{array}{l}\text { Commercieel medewerkers in het bank- } \\
\text { en verzekeringswezen }\end{array}$ \\
\hline \multicolumn{3}{|l|}{ Transport en communicatie } \\
\hline $\begin{array}{l}\text { Vliegers, scheeps-kapiteins } \\
\text { en leidinggeven-den in het } \\
\text { transport }\end{array}$ & $\begin{array}{l}\text { Sectoroverstijgend, } \\
\text { Richtingveranderend }\end{array}$ & $\begin{array}{l}\text { Leidinggevende of beveiligingsemployé in } \\
\text { de sector overheid en onderwijs }\end{array}$ \\
\hline Schippers en conducteurs & $\begin{array}{l}\text { Sectoroverstijgend, } \\
\text { Richtingveranderend }\end{array}$ & $\begin{array}{l}\text { Openbare orde en veiligheidsberoep in de } \\
\text { sector horeca en zakelijke dienstverlening }\end{array}$ \\
\hline \multicolumn{3}{|l|}{$\begin{array}{l}\text { Horeca en zakelijke } \\
\text { dienstverlening }\end{array}$} \\
\hline Organisatiedeskundigen & Richtingveranderend & $\begin{array}{l}\text { Manager in de sector horeca en zakelijke } \\
\text { dienstverlening }\end{array}$ \\
\hline \multicolumn{3}{|l|}{ Kwartaire diensten } \\
\hline Journalisten & Richtingveranderend & $\begin{array}{l}\text { Medewerkers sociaal-cultureel werk en } \\
\text { personeel en arbeid in de kwartaire } \\
\text { diensten }\end{array}$ \\
\hline Kunstenaars & $\begin{array}{l}\text { Sectoroverstijgend, } \\
\text { Richtingveranderend }\end{array}$ & $\begin{array}{l}\text { Informaticaberoep in sector overheid en } \\
\text { onderwijs }\end{array}$ \\
\hline
\end{tabular}

Afhankelijk van de beoogde overstap kunnen kansrijke scholingstrajecten verschillende kenmerken hebben. Zo kan er sprake zijn van:

- Niveauverhogende scholingstrajecten;

- Richtingveranderende scholingstrajecten; en

- Sectoroverstijgende scholingstrajecten. 
Niveauverhogende scholingstrajecten zijn erop gericht werkenden in hun bestaande vakgebied op te scholen naar een hoger niveau (bijscholing). Bij richtingveranderende scholingstrajecten gaat het hoofdzakelijk om het aanleren van een nieuw beroep op hetzelfde opleidingsniveau. Dit is bijvoorbeeld het geval wanneer een werknemer met een technisch beroep omgeschoold wordt tot commercieel medewerker. Bij sectoroverstijgende scholingstrajecten ligt de nadruk op het vergroten van de kansen op werk buiten de bedrijfssector waar men werkzaam is. Sectoroverstijgende scholingstrajecten kunnen gericht zijn op het verkrijgen van een andere functie in een andere bedrijfssector zonder dat iemand in een geheel ander beroep hoeft te gaan werken. Het kan echter ook betrekking hebben op trajecten waarbij er zowel van bedrijfssector als van functieniveau of -richting wordt gewisseld. Tabel 6.2 geeft een overzicht van de meest kansrijke scholingstrajecten die de verschillende doelgroepen voor het scholingsbeleid een beter perspectief geven op het behoud van werk.

Voor agrarische bedrijfshoofden kan een omscholing tot bedrijfshoofd in de horeca een oplossing bieden om het risico op verlies van werk als gevolg van competentieveroudering te verminderen. Een dergelijke omscholing biedt een duidelijk beter werkgelegenheidsperspectief. Bovendien participeren bedrijfshoofden in de horeca vaker in scholingsactiviteiten.

Landbouwmachinebestuurders en vissers kunnen door het volgen van een scholingstraject gericht op het vinden van werk als monteur in de handel kan arbeidsmarktperspectief verbeteren. Dit zowel richting veranderende als sectoroverstijgende scholingstraject kan het risico op verlies van werk verkleinen omdat er voor het arbeidsmarktsegment waarop de scholing zich richt de komende jaren nog een uitbreiding van de werkgelegenheid wordt verwacht. Mechanisch operators in de voedingsindustrie en productiemedewerkers in de bouw zouden ook door een omscholing tot monteur in de sector handel hun risico op verlies van werk als gevolg van comptentieveroudering kunnen beperken. Voor beide risicoberoepen is er in dat geval sprake van een sectoroverstijgend scholingstraject. Productiemedewerkers in de bouw zullen hiervoor waarschijnlijk echter een uitgebreid traject moeten doorlopen, aangezien ze voor het werk als monteur een startkwalificatie op MBOniveau nodig hebben.

Voor bouwvakkers die werkzaam zijn in de bouwsector of in de metalektro lijkt omscholing naar een economisch administratief beroep op laag niveau (bijvoorbeeld een ondersteunende administratief beroep) een interessante optie, wanneer ze zich niet meer in hun huidige functie kunnen handhaven. In deze beroepen is de fysieke belasting veel lager. Aangezien er in zowel de metalektro als de bouwsector de komende jaren een krimpende werkgelegeheid verwacht wordt, lijkt het verstandig de aandacht te richten op een scholingstraject dat bouwvakkers, waarvoor de fysieke belasting al tot gezondheidsproblemen leidt, klaarstoomt voor een economische administratief beroep op laag niveau in de handel of in de zakelijke dienstverlening. In dergelijke uitwijkberoepen is niet alleen de fysieke belasting gering, maar zijn er ook meer mogelijkheden tot scholingsparticipatie. 
Bankwerkers en lassers en metaalarbeiders in de metalektro, die relatief veel in aanraking komen met fysieke belasting tijdens het werk, zouden terecht kunnen in de energiesector wanneer ze een scholingstraject volgen waarmee ze een technisch beroep op middelbaar niveau kunnen uitoefenen, zoals bijvoorbeeld de omscholing naar elektromonteur. Deze overstap heeft als voordeel dat de fysieke belasting in het uitwijkberoep minder wordt, terwijl de scholingsparticipatie in de energiesector ook op een hoger niveau ligt. Daarnaast is er, zij het beperkte mate, de komende jaren in de energiesector nog sprake van een groeiende werkgelegenheid.

Managers en commercieel medewerkers in de metalektro zouden met een passend scholingstraject terecht kunnen in het bank- en verzekeringswezen. Voor commercieel medewerkers is tijdsdruk in het bank- en verzekeringswezen namelijk lager dan in de metalektro. Voor managers kan niet goed achterhaald worden of dat ook het geval is. Naar verwachting zal hun positie echter ook aanzienlijk kunnen verbeteren, omdat de scholingsparticipatie onder de managers in het bank- en verzekeringswezen op een hoger niveau ligt dan in de metalektro. Werktuigbouwkundig ontwerpers en hoofden technische dienst, die in de metalektro vanwege een krimpende werkgelegenheid een groot risico lopen om hun werk te verliezen, kunnen het best een scholingstraject volgen gericht op het vinden van werk in een openbare orde en veiligdheidsberoep in de sector horeca en zakelijke dienstverlening.

Het regelmatig onder een hoge tijdsdruk werken met de computer is een integraal onderdeel van het werk van journalisten, die werkzaam zijn in de grafische industrie. Als het werken onder deze tijdsdruk voor iemand teveel wordt, of het risico op RSI te hoog wordt, ligt omscholing naar een functie met minder tijdsdruk voor de hand. Een beroep dat daarvoor in aanmerking komt is bijvoorbeeld medewerker sociaal cultureel werk en personeel en arbeid. Voor de journalisten die in de grafische industrie werkzaam zijn betekent dit een overstap naar de kwartaire diensten of de sector overheid en onderwijs. De komende jaren is er in deze sectoren nog sprake van een groeiende werkgelegenheid, terwijl de psychische belasting voor medewerkers sociaal cultureel werk en personeel en arbeid relatief laag is. Grafische vakkrachten, die hun werk door een krimpende werkgelegenheid dreigen te verliezen, kunnen het best een scholingstraject volgen gericht op het verkrijgen van werk in een informaticaberoep in de sector overheid en onderwijs. In dergelijke uitwijkberoepen is de scholingsparticipatie relatief hoog. Wel moet er voor gewaakt worden dat er in zulke beroepen voldoende aandacht is voor maatregelen die erop gericht zijn RSI te voorkomen.

Schippers en conducteurs die werkzaam zijn in de sector transport en communicatie, zouden het meest gebaat zijn bij een scholingstraject dat een overstap naar een openbare orde of veiligheidsberoep in de sector horeca en zakelijke dienstverlening mogelijk maakt. Vliegers, scheepskapiteins en leidinggevenden in het transport die het risico lopen dat ze hun functie niet langer kunnen uitvoeren, omdat ze vaak onder een hoge tijdsdruk moeten werken, kunnen moeilijk in een andere bedrijfssector terecht zonder ook gelijktijdig van beroep te veranderen. Twee mogelijke uitwijkberoepen bieden perspectief op verbetering: leidinggevende in de sector overheid en onderwijs en beveiligingsemployé. In deze functies is er sprake van een minder grote 
tijdsdruk terwijl de scholingsparticipatie beduidend hoger ligt. Aangezien de meeste organisatiedeskundigen werkzaam zijn in de zakelijke dienstverlening, is de hoge tijdsdruk waaronder deze doelgroep vaak moet werken alleen te vermijden als men zowel van beroep als van bedrijfssector verandert. Gezien de affiniteit van organisatiedeskundigen met het wel en wee van organisaties ligt een overstap naar een managementfunctie voor de hand. Hoewel ook managers regelmatig onder tijdsdruk moeten werken, is hun perspectief om hier goed mee om te kunnen gaan wel beter. Managers participeren in het algemeen namelijk veel vaker in scholing dan organisatiedeskundigen.

Voor kunstenaars in de kwartaire diensten is het niet eenvoudig een uitwijkberoep op hetzelfde niveau te vinden waarbij er sprake is van minder tijdsdruk. Sommigen zouden wellicht een opleidingstraject kunnen volgen waardoor ze terecht kunnen in een technisch beroep op middelbaar of hoger niveau. Kunstenaars met ICT vaardigheden zouden wellicht in de informaticaberoepen in de sector overheid en onderwijs terecht kunnen, waar de belasting door tijdsdruk een stuk lager is. Hoewel ze dan te maken krijgen met belasting door beeldschermwerk, zijn ze wel beter beschermd tegen competentieveroudering, aangezien informatici in de sector overheid en onderwijs veel deelnemen aan opleidingen. 